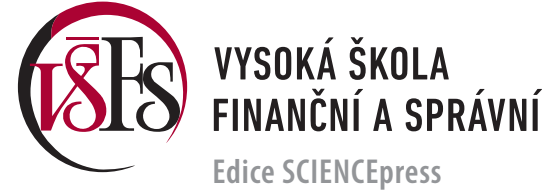

\title{
Finanční vzdělávání dospělých a jeho úroveň v 90. letech
}


Vladislav Pavlát

Finanční vzdělávání dospělých a jeho úroveň v ČR v 90. letech

Vysoká škola finanční a správní, a.s. 
Vzor citace:

PAVLÁT, Vladislav. Finanční vzdělávání dospělých a jeho úroveň v ČR v 90. letech. Praha: VŠFS, 2020. ISBN 978-80-7408-213-9.

\section{Vladislav Pavlát}

\section{Finanční vzdělávání dospělých a jeho úroveň v ČR v 90. letech}

Vydala Vysoká škola finanční a správní, a.s., v edici SCIENCEpress

Estonská 500, 10100 Praha 10

Tel.: +420210088 862

www.vsfs.cz

jako svou 316. publikaci

Recenzenti:

doc. RNDr. Přemysl Záškodný, CSc.

Ing. Vladimír Ezr, CSc.

Vydání odborné publikace bylo schváleno vědeckou redakcí nakladatelství VŠFS.

Publikace vznikla s využitím institucionální podpory na dlouhodobý koncepční rozvoj výzkumné organizace Vysoké školy finanční a správní.

Edice řídí PhDr. Jan Emmer

Vydavatelský redaktor Mgr. Petr Mach

Počet stran 152

První vydání, Praha 2020

Tisk dům tisku s.r.o.

(C) Vysoká škola finanční a správní, a.s., 2020

ISBN 978-80-7408-213-9 (online)

ISBN 978-80-7408-214-6 (print)

DOI https://dx.doi.org/10.37355/03.2020/2

Všechna práva vyhrazena. Žádná část této publikace nesmí být reprodukována a používána v elektronické podobě, kopírována a nahrávána bez předchozího písemného souhlasu nakladatele. 


\section{OBSAH}

PŘEDMLUVA ...............................................................6 6

ÚVOD ......................................................................... 7

1 Charakteristika zkoumaného období ................................. 10

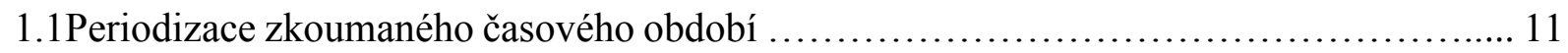

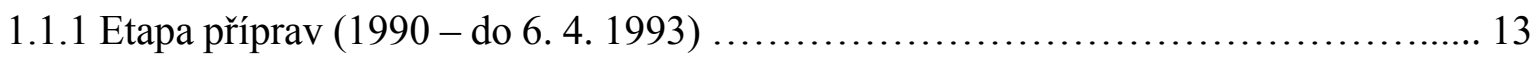

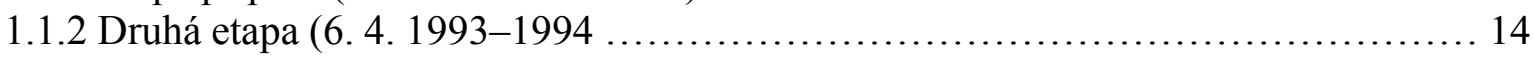

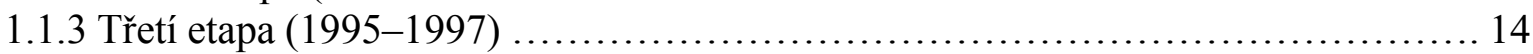

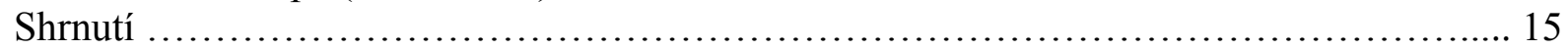

2 Předmět zkoumání, prameny a metody ................................... 17

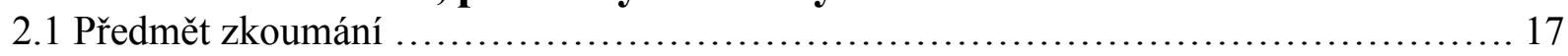

2.1.1 Předmět zkoumání a účel publikace ................................................ 17

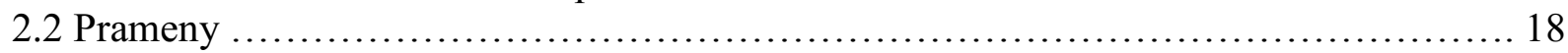

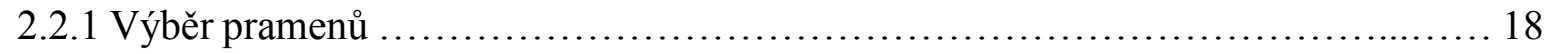

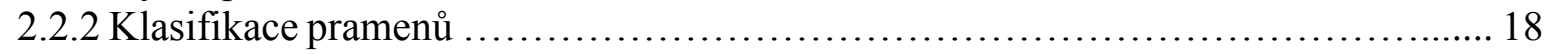

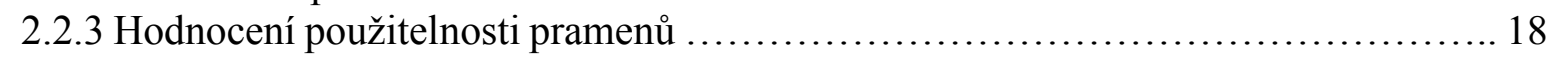

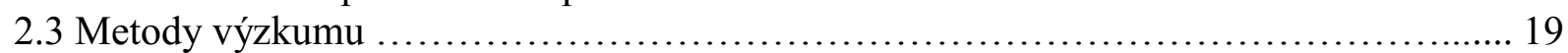

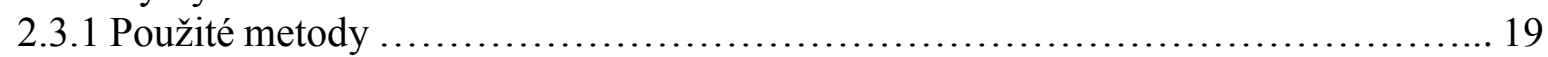

2.3.2 Metody zkoumání a postup výkladu .......................................... 19

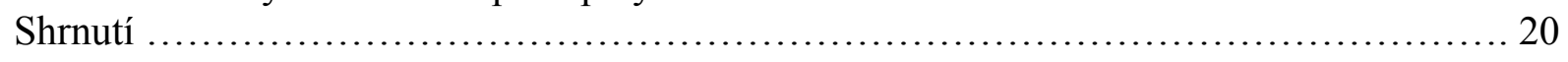

3 Základní pojmy .......................................................... 22

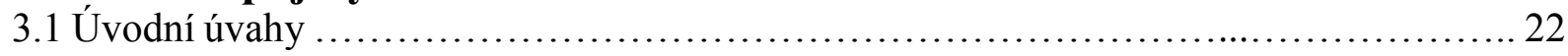

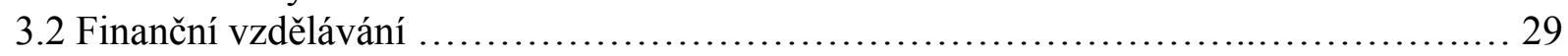

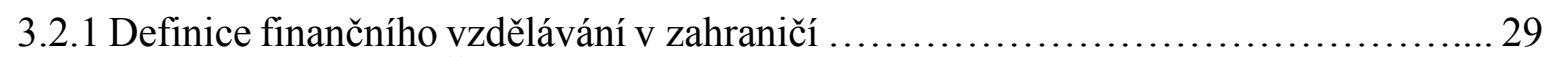

3.2.2 Definice vzdělání v ČR .............................................................. 31

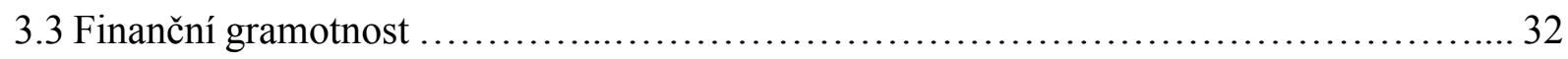

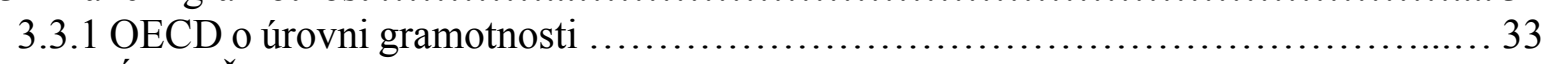

3.3.2 Účast ČR na výzkumu gramotnosti v rámci OECD .................................. 34

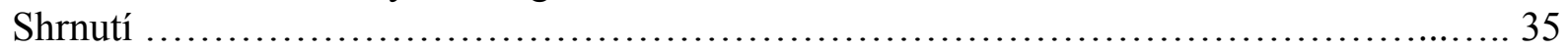

\section{Aplikace zahraničních poznatků v oblasti finančního vzdělávání}

v České republice ................................................................. 36

4.1 Nabídky zahraničních firem provádět školení o finančních otázkách ...................... 36

4.2 Překážky efektivního využití zahraniční pomoci v oblasti finančního vzdělávání ............ 38

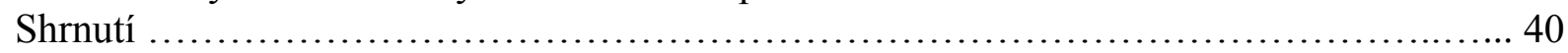


5 Úloha Ministerstva financí ČR v oblasti podpory finančního vzdělávání 41

5.1 Dozorová činnost MFČR (1990-1992) ................................................... 41

5.2 Regulace a dozor nad kapitálovým trhem v letech 1993-1994 _...................... 42

5.3 Ministerstvo financí a péče o odborné školení maklérů ............................ 44

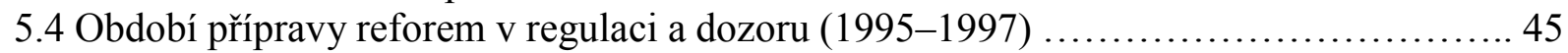

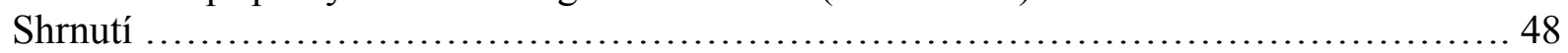

6 Úloha ČNB v oblasti podpory finančního vzdělávání ................................... 49

6.1 Zásadní iniciativa ČNB při př́pravě vzniku pražské burzy ............................... 49

6.2 Úloha Př́ípravného výboru v edukační činnosti (1991-1992) ............................ 49

6.3 Praktický význam aukcí na tzv. prozatímním sekundárním trhu SBČS ................. 49

6.4 Angažovanost centrální banky v oblasti vzdělávání pracovníků finanční sféry .......... 50

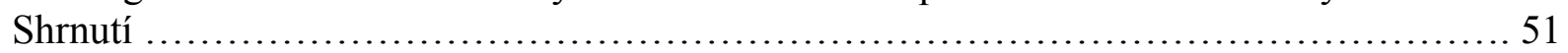

\section{7 Úloha BCPP ve finančním vzdělávání účastníků českého}

kapitálového trhu ...............................................................................................52

7.1 Obecně o očekávané úloze burzy týkající se finančního vzdělávání .................... 52

7.2 Orientace politiky BCPP v oblasti finančního vzdělávání ........................... 53

7.3 Úloha BCPP v oblasti profesního vzdělávání ..................................... 53

7.4 Účast BCPP na akcích jiných institucí k problematice kapitálových trhů ................. 53

Shrnutí ............................................................................. 56

8 Úloha médií v oblasti finančního vzdělávání v ČR ..........................557

8.1 Tiskové prameny o mimoškolním finančním vzdělávání dospělých ...................55 57

8.1.1 Poznámky k výběru pramenů a jejich využití ................................5 58

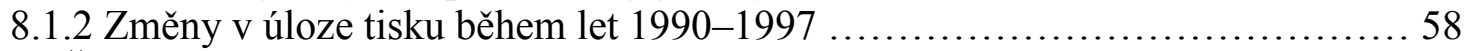

8.2 Úloha Českého rozhlasu v oblasti finančního vzdělávání dospělých ................... 66

8.3 Úloha České televize v oblasti finančního vzdělávání dospělých .......................66 66

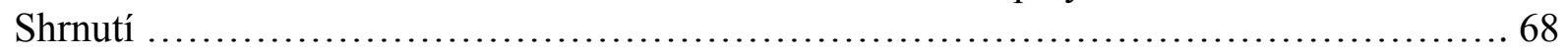

9 Úloha soukromých vzdělávacích institucí ................................669

9.1 Obecně o činnosti soukromých vzdělávacích subjektů v období let 1990-1998 .........69

9.2 IPRFT - Institut pro podporu rozvoje finančního trhu ................................ 71

9.2.1 Vybrané údaje o společnosti IPRFT ......................................... 71

9.2.2 Aktivity IPRFT v oblasti vzdělávání ........................................ 73

9.2.3 Aktivity IPRFT v informační, dokumentační a výzkumné oblasti ............ 82

9.2.4 Spolupráce IPRFT s jinými institucemi ................................. 82

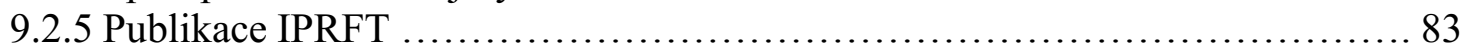

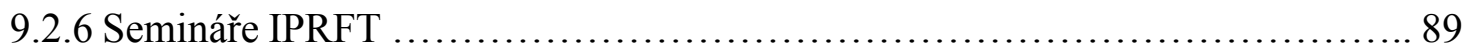

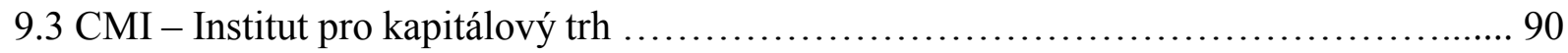

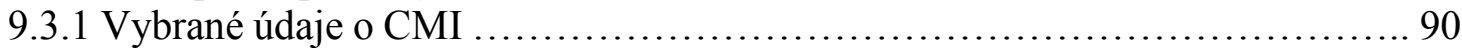

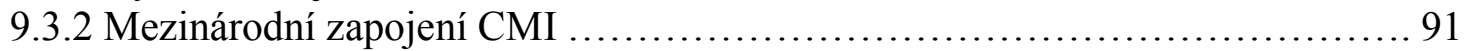

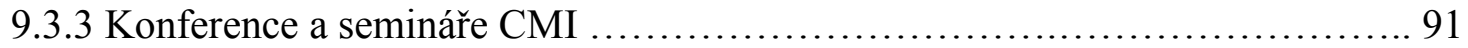

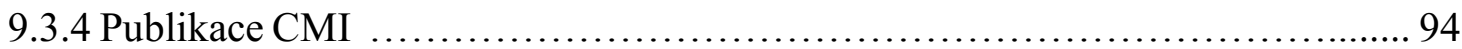

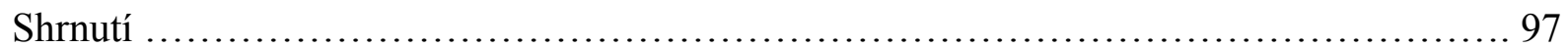


10 Výsledky zkoumání ................................................98

ZÁVĚR .................................................................... 107

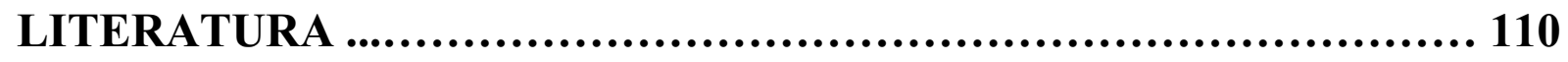

REJSTŘÍK OSOB ...................................................... 114

SEZNAM ZKRATEK ........................................................................................ 115

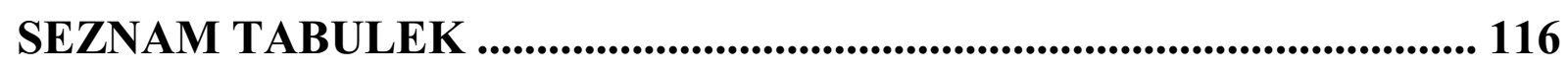

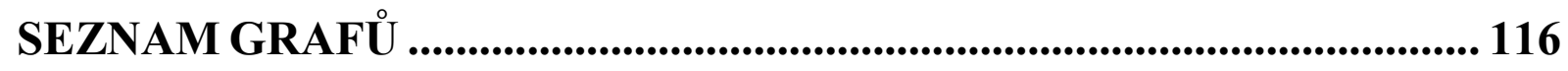

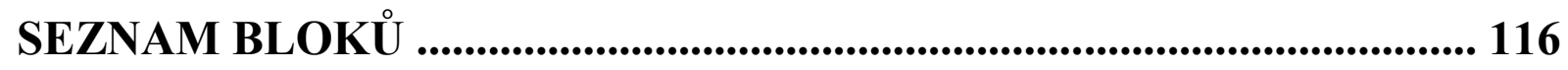

SEZNAM EXKURZŮ ............................................................................. 116

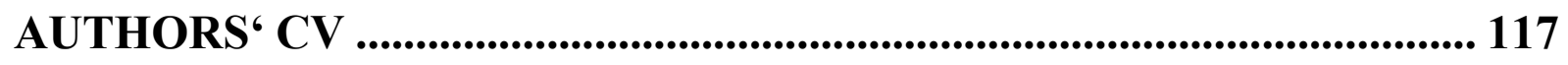

SUMMARY …............................................................................................................. 118

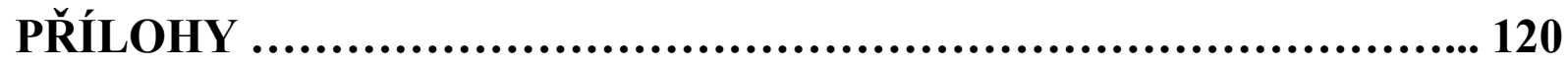




\section{P̌̌EDMLUVA}

\section{Motto: \\ Historia - magistra vitae!}

Toto antické motto někteří lidé nemají rádi, protože jim možná připomíná nějakou nepř́ijemnou událost nebo zkušenost - at' již obecně historickou, nebo osobní. Naopak slovenské rčení ,čo bolo - bolo“ se i v Čechách těší oblibě: lapidárně totiž konstatuje, že minulost je nevratná; dodejme však, že jen v té podobě, v jaké se kdysi udála.

Dnešní svět, v němž se lidé - tak jako v minulosti - rodí, žijí a umírají, se žene stále rychleji kupředu do zítřků, které i moderní věda sotva tuší.

Když jsem svého času začal psát knihu, zachycující počátky Burzy cenných papírů v Praze, které jsem v 90. letech věnoval několik roků svého života, někteří vysokoškolští kolegové se mne dotazovali, proč se tím zabývám - když už to prý dnes takřka nikoho nezajímá.

Nezajímat se o minulost znamená chovat se podle oblíbeného úsloví, že „žijeme jen jednou“ (obdoba antického carpe diem). Avšak jako člověk, jemuž bylo doprráno vyšší vzdělání, nemohu s tím souhlasit. Nemůže přece jít jen o to, že se někde něco událo, ale má a musí jít o to, nalézt skutečné prričiny, které $\mathrm{k}$ těm či oněm událostem vedly. Poznání těchto př́čin může za prríznivé situace otevř́t cestu k prevenci a k mobilizaci úsilí zabránit opakování starých chyb $\mathrm{v}$ novém rouchu.

V kterémkoliv odvětví vědy - at' jde o přírodní, technické nebo humanitní vědy - je hledání a nalézání příčin zkoumaných jevů a dějů pro badatele fascinujícím zážitkem. Snad ještě silnější je tento pocit tehdy, když se badatel kdysi událostí, které nastaly před 20-30 lety, z těch či oněch důvodů sám účastnil. Pak jde o výzvu na základě dochovaných pramenů ony př́íčiny objevit, objektivně popsat, analyzovat, vysvětlit a odůvodnit - dokud to badatel ještě udělat může.

V této odborné knize o finančním vzdělávání dospělého obyvatelstva našeho státu považuji za svou povinnost předložit získané poznatky - sine ira et studio (tedy nezaujatě a objektivně). Pro ty, kdo tuto knihu budou číst, poslouží nejen jako pouhý obraz minulosti, ale i jako pomůcka pro porovnání tehdejší úrovně finančního vzdělání s jeho dnešní úrovní. Výše zmíněné rčení „,̌o bolo - bolo“ nelze přijmout jako pouhé konstatování, že se v minulosti něco událo; nemělo by to znamenat onu ,tlustou čáru“, kterou by mnozí rádi za minulostí učinili, aniž by se z minulosti poučili. Historie je a bude naší učitelkou jen tehdy, budeme-li zkoumat, proč se to či ono kdysi událo, a budeme-li ochotni a schopni bránit tomu, aby se v novém hávu znovu neopakovaly $\mathrm{v}$ podstatě tytéž chyby, které tehdy měly negativní důsledky.

Autor publikace si na tomto místě dovoluje vyslovit svo̊j vřelý dík všem, kdo svou radou i pomocí přispěli k vydání této publikace.

V Praze dne 15. června 2020 


\section{ÚVOD}

\section{Motto: Per ardua ad astra}

Na počátku roku 1990 většina našich obyvatel - s výjimkou těch nejstarších, kteři kdysi pracovali ve finanční sféře nebo využívali finančních služeb - již prakticky neznala takové pojmy, jako burza cenných papírů, obchodování s cennými papíry, investiční fondy atd. Přechod k tržnímu hospodářství však vyžadoval, aby si co nejdříve co nejvíce našich obyvatel osvojilo alespoň základní praktické způsoby, jak racionálně nakládat s penězi, jak si založit bankovní účet a mnoho dalších praktických věcí.

Přechod ke kapitalistickému tržnímu hospodářství, na který ČSFR tehdy vykročila, se neobešel bez hlubokých změn. Jejich realizaci nebylo možno uskutečnit jinak než postupně, s podporou našeho obyvatelstva. Mezi první opatření vlády patřilo zahájení prací na změně právních předpisů a paralelně - v souladu s Vládním prohlášením - postupovaly změny v ekonomice, v institucionální oblasti a v personální politice.

Rozhodování, s čím začít, nebylo nikterak jednoduché. Do cesty se stavěly četné překážky, mezi něž na neposledním místě patřila setrvačnost v myšlení lidí a jejich chování, kterou nelze jednorázově odstranit změnami označení nových institucí nebo výměnou několika úředníků. Vládní prohlášení z roku 1990 sice obsahovalo i zmínku o školství a potřebě nové náplně činnosti tohoto resortu, $v$ podstatě však tato činnost byla chápána převážně jako zabezpečování fungování školské výuky na všech typech škol. Péče o mimoškolní vzdělávání a výchovu objektivně vzato - se v tehdejší vzrušené době snad ani nemohla stát prioritou (Mlčoch, 2001).

Tato publikace se snaží popsat, rozebrat, vysvětlit a hodnotit události, které během poslední dekády 20. století probíhaly v oblasti mimoškolní výuky dospělých, zaměřené na finanční sféru. Finanční sféra patřila mezi ty součásti národního hospodářství, jejichž význam s přechodem k tržní ekonomice výrazně vzrostl. Dostatečně si uvědomit a hlouběji pochopit rostoucí význam finančních otázek a jejich dopad na každodenní život lidí mohl jen ten, kdo se naučil nové pojmy a zvládl jejich obsah, aby byl schopen své nové znalosti uplatnit při svém rozhodování v praxi.

Získat potřebné a užitečné znalosti však tehdy nebylo zcela jednoduché, nebot' do cesty mimoškolního vzdělávání dospělých se stavěly různé překážky. Jedním z úkolů této publikace je rozbor těchto překážek a jejich vlivu na rozvoj finančního vzdělávání a na jeho úroveň. S tím bezprostředně souvisí otázka, zda a do jaké míry finanční vzdělávání ve sledovaném období korespondovalo potřebám rozvoje kapitálového trhu v České republice a jak přispívalo k řešení jeho problémů. V publikaci je rovněž hodnocen vliv zahraničních institucí na vývoj českého finančního vzdělávání.

Publikace dále zkoumá, zda a jak se během zkoumaného období úroveň finančního vzdělávání dospělých přibližovala úrovni finanční gramotnosti v zemích Evropské unie. Výsledky tohoto zkoumání umožnily vytvořit si představu o tom, do jaké míry se vlády ČSFR (v prvních třech letech po r. 1989) a poté vlády České republiky (v letech 1993-1997) vypořádaly s počáteční nízkou (takřka nulovou) úrovní finanční vzdělanosti. 
Po vymezení koncepce a poslání publikace (odborně označované názvem „odborná kniha“) a po výkladu základních pojmů používaných v této knize se výklad vlastní zkoumané tematiky finančního vzdělávání v ČR ubírá po třech liniích: předně, po institucionální linii - po linii činnosti jednotlivých ministerstev, která se v souladu se svými pravomocemi př́mo neb nepř́mo zabývala otázkami finančního vzdělávání; ${ }^{1}$ za druhé, po linii činnosti vybraných skupin institucí; za třetí, po linii zkoumání úlohy médií a soukromých vzdělávacích institucí. ${ }^{2}$

Samostatná kapitola o úloze MŠMT v oblasti celoživotního vzdělávání dospělých během let 1990-1997 byla vzhledem k jejímu očekávanému značnému rozsahu po dohodě s vydavatelstvím VŠFS vypuštěna; autor zvažuje její pozdější samostatné vydání.

Celkové výsledky bádání jsou shrnuty v samostatné kapitole (kap. 10), která hodnotí př́nos dílčích poznatků, získaných $\mathrm{v}$ jednotlivých částech publikace $\mathrm{z}$ citovaných pramenů, pro celkový rozvoj mimoškolního finančního vzdělávání dospělých $\mathrm{v}$ jednotlivých fázích vývoje českého kapitálového trhu v období let 1990-1997.

Na tomto místě autor výslovně zdůrazňuje, že pokládá většinu prací o celoživotním vzdělávání dospělých, které uveřejnily instituce a jednotliví badatelé po r. 2000, za mimořádně př́nosné pro celkové hodnocení vývoje českého školství po r. 1989 řízeného MŠMT. Rozsáhlé pozitivní výsledky tohoto badání byly mj. podmíněny vstupem České republiky do OECD a jejím členstvím v UNESCO. Východiskem akademického výzkumu voblasti edukace se stala Národní strategie finančního vzdělávání (2010).

Nová odborná kniha o finančním vzdělávání dospělých, nyní vydávaná péčí Vysoké školy finanční a správní v Praze, představuje pouze skromný příspěvek k rozsáhlé literatuře o vývoji českého školství po r. 1989. Její zpracování autor podřídil své koncepci finančního vzdělávání založeného na zpětné vazbě reálného vývoje finanční sféry a tomuto vývoji odpovídající úrovni finančního vzdělávání, orientovaného zejména na oblast finančního investování. V podstatě jde o komplementární výzkum, přinášející některé dosud neznámé poznatky o finančním vzdělávání po institucionální linii.

Text vlastního výkladu byl doplněn vsunutím několika stručných „Blokü“, které obsahují vybraná fakta, bez jejichž znalosti nelze plně pochopit důvody řady událostí. Podobnému účelu mají rovněž sloužit Exkurzy, doplňující detailní údaje, které by mohly př́iliš zatížit nit' hlavního výkladu. Některé informace byly z praktických důvodů zařazeny do poznámek pod čarou.

Kniha byla zpracovávána (včetně výběru veřejných i neveřejných archivních pramenů) během období 2018-2020. V Př́loze jsou uvedeny naskenované originální prameny k problematice vybraných kapitol, ze značné části dosud neuveřejněné. Př́ilohy slouží hlavně jako ilustrace

\footnotetext{
${ }^{1}$ Po rozdělení Československa došlo k řadě institucionálních změn. Zdrojem problémů se stalo - mimo jiné nedokonalé vymezení a právní zakotvení kompetence ministerstev jakožto ústředních orgánů státní správy. V této práci se této skutečnosti dotýkáme spíše jen okrajově. I když nelze podceňovat negativní dopady této skutečnosti, nebot' překrývání nebo nepokrývání různých činností může vyvolávat různá tření, v rámci omezení rozsahu naší publikace bylo možno se těmito otázkami zabývat jen nepř́mo, zejména $\mathrm{v}$ souvislosti s dopady na regulaci finanční sféry a finančního trhu. Pro podrobnější osvětlení těchto otázek nutno odkázat na prameny Ministerstva spravedlnosti. Z akademické literatury lze uvést např. právní studii M. Možné (MOŽNÁ, Michaela, 2015. Vývoj právní úpravy vzdělávání dospělých v České republice) aj.

${ }^{2}$ Bližší charakteristika zvoleného vícevrstevného výkladu je popsána ve shrnutí kap. 2
} 
událostí, akcí nebo činností spojených s předmětem zkoumání. Lze však je chápat i jako důkazy dokládající určité názory nebo aktivity. (Větší část př́iloh se vztahuje ke kapitole 9; jsou součástí dochované části archivu společností IPRFT a CMI.) 


\section{Charakteristika zkoumaného období}

Pro hlubší pochopení změn v pojetí finančního vzdělávání dospělých po r. 1989 je nezbytné zasadit je do souvislosti s historickými událostmi, jimiž změny v české vzdělávací soustavě byly podmíněny a umožněny. Při charakteristice obsahu této knihy $\mathrm{v}$ Úvodu byla sice o některých z těchto souvislostí stručná zmínka, avšak výklad se nevztahoval př́mo ke vzdělávání dospělých.

V této kapitole konfrontujeme hlavní události týkající se vzniku kapitálového trhu v ČSFR, resp. ČR v jejich historickém sledu let 1990-1997 s hlavními událostmi finančního vzdělávání dospělých (viz Blok 1). Toto porovnání je důležité nejméně ze dvou důvodů: 1 . z teoretického hlediska, nebot' mezi porovnávanými skutečnostmi existují významné vztahy, které v průběhu času nejsou neměnné; 2 . z praktického hlediska, nebot' tyto vztahy se mohou úspěšně utvářet jen tehdy, umožňují-li to odpovídající právní předpisy a politicko-hospodářská opatření.

Obecně je uznáváno, že finanční vzdělávání a dostatečná úroveň finančního vzdělání je nezbytnou podmínkou pro efektivní fungování kapitálových trhů. Finanční investování vyžaduje, aby účastníci trhu měli nejen všeobecné základní vzdělání (tj. aby uměli číst, psát a počítat), ale také speciální finanční znalosti a dovednosti, nezbytné k účasti na kapitálovém trhu jako velmi významné součásti finančního trhu.

Kapitálový trh plní v rámci finančních trhů specifické funkce a jeho rozvoj je podmíněn stavem a vývojem reálné ekonomiky, zejména jejího finančního sektoru.

Výsledkem finančního vzdělávání (chápaného jako proces) je dosažení takové úrovně finanční vzdělanosti (viz kap. 3), která na daném stupni rozvoje finančního systému společnosti může umožňovat hladký a efektivní chod kapitálového trhu.

Obsah finančního vzdělávání obecně závisí na dosaženém stupni rozvoje reálné ekonomiky, tj. má účastníkům kapitálového trhu poskytnout znalosti, které jim umožňují fungovat ve finanční sféře.

Proto nutno objektivní zkoumání vývoje finančního vzdělávání považovat za užitečné a účelné jen při respektování zpětné vazby mezi finančním vzděláváním a reálnou ekonomikou (finanční sférou).

$\mathrm{Z}$ tohoto důvodu jsou v této knize při rozboru finančního vzdělávání v různých etapách jeho vývoje stručně charakterizovány důležité události ve finanční oblasti, které mohly být příčinou změn v obsahové náplni finančního vzdělávání, v použití nových technických pomůcek, ve způsobu výkladu aj. Zkoumání dílčích konkrétních kauzalit není předmětem zkoumání v této publikaci; uváděné př́íklady mají ilustrativní povahu.

Princip zpětné vazby při analýzách finančního vzdělávání a měření úrovně finančních znalostí lze považovat za paradigma, jehož respektování je zárukou objektivity zkoumání a dosažených výsledků. 


\subsection{Periodizace zkoumaného časového období}

Účelem periodizace období zkoumaného v této publikaci je rozčlenit toto období let 1990-1997 na základní časové etapy, které se vzájemně lišily odlišnou povahou zkoumaných událostí, a umožnit tím lépe vysvětlit jejich obsah, význam a dopady. Uvedenou periodizaci autor zpracoval speciálně pro tuto publikaci ( $\mathrm{tj}$. $\mathrm{v}$ této podobě dosud nebyla uveřejněna $\mathrm{v}$ jiných autorových publikacích).

Základním členěním je rozlišení tří základních období zkoumaného vývoje:

1. etapa $=1990-6.4 .1993$

2. etapa $=6.4 .1993-1994$

3. etapa $=1995-1997$ (počátek reformních kroků)

Jednotlivé etapy se navzájem odlišují svým specifickým charakterem, který jim vtiskly hlavní události na kapitálovém trhu a hlavní události v oblasti finančního vzdělávání a spolu s tím také vývoj regulace obou procesů.

Zkoumané období zahrnuje pouze necelou jednu třetinu z trricetiletého vývoje od r. 1989, avšak pro celkový vývoj do současnosti mělo mimořádný význam vzhledem ke své specifické povaze. Během zkoumaného osmiletého období se vztahy srovnávaných skutečností vyvíjely odlišným způsobem, což vedlo $\mathrm{k}$ tomu, že v různých fázích tohoto vývoje lze vymezit specifické dopady, jimiž se jednotlivé fáze navzájem odlišovaly.

Výběr událostí zařazených do dále uvedeného bloku se omezuje na ty z nich, které nejvíce prrispěly ke specifickému charakteru daných etap sledovaného období let 1990-1997.

Blok 1

Významné události na kapitálovém trhu ČR a ve finančním vzdělávání dospělých

\begin{tabular}{|c|c|c|}
\hline Etapy & Hlavní události na kapitálovém trhu & $\begin{array}{l}\text { Hlavní události v oblasti finančního } \\
\text { vzdělávání dospělých }\end{array}$ \\
\hline $\begin{array}{l}\text { 1. } \\
1990- \\
\text { duben } \\
1993\end{array}$ & $\begin{array}{l}\text { - Vznik Přípravného výboru } \\
\text { - Vznik Prozatímního sekundárního } \\
\text { trhu SBČS } \\
\text { - Vznik Komise pro koordinaci } \\
\text { kapitálového trhu (Klaus, 1992) } \\
\text { - Založení BCPP, a.s. } \\
\text { - Zř́zení poradní komise pro udělování } \\
\text { povolení k vydávání cenných papírů } \\
\text { - Uzavření smlouvy mezi SBF a } \\
\text { BCPP o technické pomoci } \\
\text { - Vydání zákona o burzách cenných } \\
\text { papírů } \\
\text { - Vydání zákona o cenných papírech }\end{array}$ & $\begin{array}{l}\text { - Seminář pro banky a spořitelny } \\
\text { (1991) } \\
\text { - Vydání vyhlášky o makléřských } \\
\text { zkouškách } \\
\text { - Zřízení zkušební komise MFČR pro } \\
\text { provádění makléřských zkoušek }\end{array}$ \\
\hline 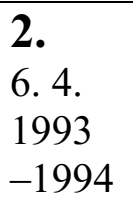 & $\begin{array}{l}\text { - Zahájení obchodování na BCPP } \\
\text { a RM-S } \\
\text { - Postupné vydávání předpisů BCPP } \\
\text { - SCP začalo fungovat jako }\end{array}$ & $\begin{array}{l}\text { - Zahájení makléřských zkoušek } \\
\text { - Zahájení kurzů IPRFT pro makléře }\end{array}$ \\
\hline
\end{tabular}




\begin{tabular}{|c|c|c|}
\hline & mimoburzovní trh & $\begin{array}{l}\text { - Mezinárodní seminář (ř́ijen 1993) } \\
\text { „Podmínky a perspektivy rozvoje } \\
\text { kapitálového trhu a burzy v ČR“ } \\
\text { - 15. 12. } 1992 \text { vyšlo nulté číslo prvního } \\
\text { specializovaného měsíčníku „ABK - } \\
\text { Akcie-Burza-Kapitál.“ - Od 1. } 1 . \\
1994 \text { měsíčník ABK vycházel do r. } \\
1996 \\
\text { - BCPP začala vydávat časopis } \\
\text { „Burza“ (1994) } \\
\text { - Semináŕ IPRFT (prosinec 1994) } \\
\text { „Informačni povinnost emitentů } \\
\text { cenných papirů“ }\end{array}$ \\
\hline $\begin{array}{l}\mathbf{3 .} \\
1995- \\
1997\end{array}$ & $\begin{array}{l}\text { Přípravné práce ke zrŕzení Komise pro } \\
\text { cenné papíry }(\mathrm{KCP})\end{array}$ & $\begin{array}{l}\text { - Semináŕ (únor 1995) „Základní } \\
\text { východiska pro efektivnější fungování } \\
\text { kapitálového trhu v ČR“ } \\
\text { - BCPP začala vydávat „Burzovní } \\
\text { věstník“ (1995) } \\
\text { - Konference Nadace Patriae (duben } \\
\text { 1996) } \\
\text { - Burza vydává Fact Book (první v r. } \\
\text { 1995, druhá v r. 1996) } \\
\text { - Mezinárodní semináŕ EDI a IPRFT } \\
\text { (květen 1996) }\end{array}$ \\
\hline
\end{tabular}

Prameny: výběr pramenů provedl autor podle hledisek uvedených v kap. 2.2.1.

V průběhu prvního základního období, které je považováno za prŕípravnou etapu, byly položeny legislativní základy českého kapitálového trhu a jeho infrastruktury.

Poznámka: Celkový proces vzniku českého kapitálového trhu autor ve svých předchozích pracích (Pavlát, 2008) původně rozčlenil na tři dílčí etapy, a to takto: (a) první dílčí etapa: od ledna do prosince 1990; (b) druhá dílčí etapa: od prosince 1990 do prosince 1991; (c) třetí dílčí etapa: od ledna 1992 do dubna 1993 (6. dubna 1993). V této publikaci bylo od tohoto podrobnějšího členění upuštěno. Rovněž u druhého a třetího základního období bylo od podrobnějšího členění na dílčí etapy (podetapy) v zájmu zjednodušení analýzy upuštěno.

Dělicí čarou mezi první a druhou etapou je ukončení institucionálních organizačních a technických př́prav, jimiž bylo podmíněno zahájení obchodování cennými papíry na obou veřejných trzích (BCPP a RM-S).

Za dělicí čáru mezi druhou a třetí etapou lze považovat odklon od príliš liberálního pojetí regulace obchodování ke zpř́snění regulace a k částečné realizaci reformních požadavků odborné veřejnosti. Tato dělicí čára se sice může jevit jako nepřesná, avšak rok 1995 je bodem zlomu na cestě vzniku Komise pro cenné papíry. 


\subsubsection{Etapa příprav (1990-do 6. 4. 1993)}

V tomto odstavci jsou stručně rekapitulovány poznatky o př́ípravách na založení pražské burzy z let 1990-1993 (Pavlát, 2007), které jsou v dalším výkladu doplněny o další poznatky.

První dílčí část „období př́prav“ (leden až prosinec 1990) je charakterizována nekoordinovanými a v podstatě chaotickými snahami jednotlivců a různých skupin usilujících o naplnění té části Programu československé vlády, která obsahovala záměr obnovit pražskou burzu cenných papírů.

Díky těmto iniciativám byla uveřejněna $v$ českém tisku řada článků vysvětlujících význam burz cenných papírů na vznikajícím kapitálovém trhu. Některé z těchto článků - v podstatě vzdělávacích, resp. osvětových (tj. nikoliv odborných) - obsahovaly i konkrétní návrhy na vhodný postup při obnově pražské burzy. Toto úsilí vyústilo v založení „Přípravného výboru“ v listopadu 1990.

Během této doby probíhaly legislativní činnosti čs. vlády, směřující k přijetí nových zákonů, umožňujících přechod od tzv. plánovaného hospodářství ke vzniku kapitalistické tržní ekonomiky (Pavlát, O vzniku Burzy cenných papírů, 2008. Kap. 6, 9 a 14). Tyto legislativní práce nebyly sice dostatečně koordinovány, avšak zabránily snahám některých subjekti̊ o živelné, nekontrolované emise cenných papírů, zejména dluhopisů. I když řada zákonů týkajících se českého kapitálového trhu musela být později velmi často novelizována, jejich schválení a praktická aplikace byla v té době značným pokrokem.

Otázku finančního vzdělávání však tehdejší garnitura politiků nepovažovala za prioritní, což později poměrně značně komplikovalo situaci: většina obyvatelstva jen velmi pomalu a opožděně chápala hospodářskou politiku tehdejší vlády, která za svou prioritu považovala tzv. kuponovou privatizaci.

Druhá dílčí část období prríprav (od prosince 1990 do prosince 1991) probíhala v duchu diskusí o různých možných variantách vzniku kapitálového trhu a vhodného modelu burzy. V této etapě proběhla řada kabinetních jednání Přípravného výboru s potenciálními uchazeči o členství v burze, jejichž obsah pronikal i do tisku. V denním tisku se začaly častěji objevovat různé informace o kapitálovém trhu, jeho institucích i nástrojích. Byla ventilována mj. také otázka, zda by místo burzy cenných papírů mohl fungovat tzv. RM-systém, který by hrál rozhodující úlohu při uskutečňování první etapy kuponové privatizace.

V těchto diskusích se projevoval poměrně značný informační chaos; objevila se řada chybných laických představ i zmatených názorů. Pro ilustraci lze uvést napřr. názor některých zájemců z řad podnikatelů o obchodování cennými papíry na pražské burze (krátce po zahájení obchodování v r. 1994), že by burza měla podnikatelům platit za informace, které jí poskytují o svém podnikání v př́ípadě obchodování akciemi jejich podniků.

Třetí dílčí část období příprav (od ledna 1992 do 6. 4. 1993), kdy Př́ípravný výbor definitivně prosadil urychlení založení pražské burzy, byla pro další formování českého kapitálového trhu a jeho potřebám odpovídající soustavy finančního vzdělávání rozhodující. Na základě výsledku 
předchozích mezinárodních konzultací, velkého počtu shromážděných zahraničních publikací a dokumentů i výsledků předchozích analýz, které Př́ípravný výbor získal od ČNB, bylo rozhodnuto uzavřít (v rámci existujících dohod o francouzské pomoci Československu mezi vládou České republiky a vládou Francouzské republiky) smlouvu s Pařížskou burzou o budování pražské Burzy cenných papírů. Tato smlouva byla v Praze podepsána v březnu 1992 a francouzský tým zahájil svou činnost na místě bezprostředně po jejím podepsání. Mise francouzského týmu byla ukončena ke dni 6. dubna 1993, kdy BCPP oficiálně zahájila obchodování.

\subsubsection{Druhá etapa (6. 4. 1993-1994)}

Druhou etapu formování českého kapitálového trhu a soustavy finančního vzdělávání (duben 1993-1994) odpovídající jeho potřebám lze stručně charakterizovat jako období, kdy byly dobudovány institucionální základy kapitálového trhu a kdy tyto instituce začaly fungovat (včetně potřebné infrastruktury).

V tomto období započala praktická realizace základního finančního vzdělávání pracovníků činných v oblasti českého kapitálového trhu: zejména školení makléřů a rozvoj informační a osvětové činnosti pro veřejnost v tisku, rozhlasu a televizi (kap. 7).

\subsubsection{Třetí etapa (1995-1997)}

Třetí etapa formování českého kapitálového trhu a soustavy finančního vzdělávání je obdobím počátků dílčích reforem českého kapitálového trhu. Cílem těchto dílčích reforem bylo jednak odstranění dílčích nedostatků a nešvarů $\mathrm{v}$ tehdejší praxi účastníků kapitálového trhu, jednak snaha o přizpůsobení českého kapitálového trhu a chování jeho účastníků směrem k uznávání a praktické aplikaci standardů evropských kapitálových trhů.

V oblasti finančního vzdělávání došlo v třetí etapě jeho vývoje ke vzniku nových vzdělávacích subjektů, obvykle fungujících na základě živnostenských oprávnění. Byly to většinou zprostředkovatelské subjekty, které se zabývaly organizací jednotlivých přednášek k aktuálním otázkám vývoje kapitálového trhu, na něž získávaly př́ležitostné lektory. Tyto přednášky byly nabízeny širší veřejnosti prostřednictvím inzerce nebo pomocí osobních dopisů; podnikům bylo nabízeno také uspořádání krátkodobých kurzů z různých tematických oblastí souvisejících s podnikovou finanční agendou (např. z oblasti účetnictví, personalistiky apod.). Někteří jednotlivci z řad zaměstnanců podniků finanční sféry, např. $\mathrm{z}$ bank nebo z centrálních úřadů, kteří se specializovali na určitá aktuální témata (např. účetnictví, finanční opce apod.), pořádali samostatné přednášky nebo krátkodobé kurzy. Jedním ze specialistů, kteří přednášeli o finančních opcích, byl nap̌r. tehdejší člen vedení Komerční banky Ing. Petr Budínský, CSc.

V tomto období proběhlo také několik zajímavých konferencí nebo seminářů (některé s mezinárodní účastí), jejichž výsledky měly pozitivní vliv na vývoj názorů pracovníků finanční sféry. Na těchto akcích se diskutovalo o řadě sporných problémů v prítomnosti vedoucích představitelů státní správy, bank nebo BCPP. Některá praktická řešení byla inspirována těmito diskusemi. Informace o nich jsou uvedeny zejména v kap. 7 a 8 . Jedním ze základních požadavků zastánců reforem byl požadavek, aby neprodleně byla zřízena Komise pro cenné 
papíry jako vrcholný orgán regulace českého kapitálového trhu, což se však prakticky realizovalo až v r. 1998.

Blok 2

\section{Financování vzniku BCPP}

Značnou zásluhu na profinancování vzniku pražské burzy má tehdejší ministr pro hospodářskou politiku a rozvoj Karel Dyba. V situaci, kdy členské banky se de facto zdráhaly investovat finanční prostř̌edky nutné $\mathrm{k}$ založení burzy a $\mathrm{k}$ financování počátečního období její činnosti ze svých vlastních, právě on nalezl vhodné řešení aplikací tehdejší smlouvy mezi francouzskou vládou a vládou České republiky o možnosti poskytování pomoci České republice $\mathrm{v}$ transitivním období.

Z publikace „O vzniku cenných papírư“ (Pavlát, 2008) k tomu její autor cituje:

„Není možno neuvést, že díky velkorysému postoji francouzské vlády, ... ministerstva financí a SBF byla hodnota poskytnuté pomoci oceněna velmi skromnou částkou 10 mil. Kč. Skutečná hodnota této pomoci však reálně byla nesrovnatelně vyšší... K realizaci (této pomoci - pozn. V. P.) značně přispěl vstřícný postoj tehdejšího ministra vlády ČR Ing. Karla Dyby, CSc.. Není nikterak nadsázkou říci, že bez jeho podpory by burza snad ani nebyla schopna zahájit svou činnost $\mathrm{v}$ tak krátkém čase. Dík náleží i náměstkovi ministra financí Ing. Miroslavu Purkyněmu, který s osobním nasazením pružným způsobem dokázal překonat poslední hrozící byrokratické překážky.“

Jednou z př́íčin neochoty bank investovat do založení burzy vlastní peníze mimo jiné bylo to, že nebyla ujasněna koncepce institucionálního uspořádání českého kapitálového trhu.

Přestože byla na základě usnesení Finanční rady ČSFR v únoru 1992 zř́izena komise ke koordinaci rozvoje kapitálového trhu (viz jmenovací list z 12. 2. 1992 k čj. CKP/3662/1992 v Př́loze), tato komise ani do r. 1994 nedospěla k žádnému jednoznačnému rozhodnutí (viz též Miller, The Czech Capital Market, Interim Report, October 1994).

\section{Shrnutí}

Předkládaná publikace „Finanční vzdělávání dospělých a jeho úroveň v ČR v 90. letech “ byla zpracována jako „odborná kniha“, odpovídající definici druhu výsledků podle usnesení vlády ČR ze dne 29. 11. 2017 č. $837 .^{3}$

V kapitole 1 se vychází z obecného východiska, že finanční vzdělávání a jeho úroveň je nezbytnou podmínkou pro efektivní fungování kapitálových trhů. Finanční investování vyžaduje, aby účastníci trhu měli nejen všeobecné základní vzdělání (tj. aby uměli číst, psát a počítat), ale aby také měli speciální finanční znalosti a dovednosti, nezbytné k účasti na kapitálovém trhu jako velmi významné součásti finančního trhu. Tento požadavek odpovídá stanoviskům mezinárodních organizací z 90. let minulého století (UNESCO, OECD aj.).

\footnotetext{
${ }^{3}$ Úřad vlády ČR. Čj. 26822/2017-OMP. Definice druhu výsledků. Samostatná př́loha č. 4 Metodiky hodnocení výzkumných organizací a programů účelové podpory výzkumu, vývoje a inovací, schválené usnesením vlády dne 8. února 2017 č. 107 . Str. 5-6.
} 
Kapitálový trh plní v rámci finančních trhů specifické funkce a jeho rozvoj je podmíněn stavem a vývojem reálné ekonomiky, zejména jejího finančního sektoru.

Výsledkem finančního vzdělávání (chápaného jako proces) je dosažení takové úrovně finančního vzdělání (viz kap. 3 - základní pojmy) v daném období, která umožňuje hladký a efektivní chod kapitálového trhu. Tento názor odpovídá většinovému teoretickému názoru. Předpokládaný příčinný vztah však není jednoznačně prokázán. V praxi existují faktory, které předpokládaný vztah mohou negovat.

Obsah finančního vzdělávání obecně závisí na dosaženém stupni rozvoje reálné ekonomiky, tj. obsah vzdělávání má účastníkům kapitálového trhu poskytnout znalosti, které jim umožňují úspěšnou činnost ve finanční sféře.

Periodizaci hlavních událostí v letech 1990-1997, uvedenou v kapitole 2, autor nově upravil pro tuto publikaci.

Základním členěním je rozlišení tř́i základních období zkoumaného vývoje:

1. etapa $=1990-6.4$. 1993; 2. etapa $=6.4$. 1993-1994; 3. etapa $=1995-1997$ (počátek reformních kroků).

V prvním (přípravném) období rozvoje českého kapitálového trhu (1990-1992) tehdejší garnitura politiků nepovažovala otázku finančního vzdělávání za prioritní. Přesto však již v tomto období na základě soukromých iniciativ a po založení tzv. Př́pravného výboru i díky jeho činnosti byly položeny základy finančního vzdělávání dospělého obyvatelstva.

V druhém období (1993-1994) započala praktická realizace základního finančního vzdělávání pracovníků činných v oblasti českého kapitálového trhu díky aktivitám ČNB, MFČR, BCPP (zejména školení makléřů; rozvoj informační a osvětové činnosti pro veřejnost v tisku, rozhlasu a televizi).

Třetí etapa formování českého kapitálového trhu a soustavy finančního vzdělávání je obdobím počátků dílčích reforem českého kapitálového trhu, které byly zaměřeny za prvé, na omezení a/nebo odstranění existujících anomálií, za druhé, na př́pravu přechodu ke standardnímu modelu evropských kapitálových trhů. 


\section{Předmět zkoumání, prameny a metody}

Tato kapitola 2 je věnována vymezení předmětu zkoumání, jímž se publikace zabývá (2.1), diskusí o jejích pramenech (2.2) a metodami, aplikovanými při jejím zpracovávání (2.3). Všechny tyto 3 subkapitoly patří mezi závazné charakteristiky publikací, označovaných v ČR za odbornou knihu.

Některé názory, obsažené v této kapitole, byly pozdějším vývojem po r. 2000 překonány nebo modifikovány. Proto lze čtenářům, kteří se sami nevěnují bádání o vzdělávání dospělých v ČR, doporučit, aby tuto kapitolu, která místy má technický charakter, vynechali a přešli k následující 3. kapitole. Odborné diskuse o vzdělávání dospělých, které se rozvinuly během doby po r. 2000, ani zdaleka nejsou uzavřeny.

\subsection{Předmět zkoumání}

Vymezení předmětu zkoumání je podstatnou součástí náležitostí odborné publikace. Někdy bývá spojeno s omezením zkoumaného předmětu (např. s jeho zúžením) nebo naopak i s jeho rozšířením, jehož důvodem mohou být skutečnosti, zjištěné během bádání.

\subsubsection{Předmět zkoumání a účel publikace}

Předmětem zkoumání v této publikaci je finanční vzděláváni a jeho úroveň v ČR v obdobi let 1990-1997 v souvislosti s konstituováním českého kapitálového trhu.

Účelem publikace a jejím posláním je vyplnit mezeru existující v odborné literatuře věnované zkoumání počátků finančního vzdělávání a jeho úrovně $\mathrm{v}$ souvislosti $\mathrm{s}$ vývojem českého kapitálového trhu, zkoumat hybné síly tohoto procesu a přispět $-\mathrm{s}$ odstupem více než dvou desetiletí - k jeho objektivnímu hodnocení. Zkoumání stavu finančního vzdělávání bylo zaměřeno prioritně na mimoškolní finanční vzdělávání dospělého obyvatelstva České republiky.

Publikace se zabývá výše uvedeným předmětem zkoumání v rozsahu vymezeném autorovou smlouvou s vydavatelstvím EUPRESS Vysoké školy finanční a správní. Autor prováděl výběr pramenů s ohledem na řadu dále uvedených skutečností:

(a) původních českých prací týkajících se přímo finančního vzdělávání v první polovině 90 . let bylo vydáno nemnoho;

(b) publikace se nezabývá právní problematikou (citace právních předpisů většinou slouží jako príklady);

(c) zkoumání bylo omezeno na mimoškolní finanční vzdělávání dospělých;

(d) při analýze úlohy médií v oblasti finančního vzdělávání byla největší pozornost věnována úloze tisku, který během zkoumaného období hrál v informační oblasti hlavní roli;

(e) z archivních dokumentů ústředních úradů státní správy byly do rozborů zařazeny pouze dokumenty př́stupné veřejnosti;

(f) vzhledem k omezenému rozsahu této publikace musel být rozsah disponibilních př́loh omezen; některé přílohy byly uveřejněny ve zkráceném znění;

(g) do části kap. 8 a 9 této publikace mohly být $\mathrm{v}$ důsledku omezení jejího rozsahu zařazeny pouze nejdůležitější informace. 
Uvedené skutečnosti nejsou seřazeny podle své významnosti. Stanovení jejich pořadí by si vyžádalo podrobnějš́ího rozboru.

Tato odborná kniha je koncipována jako příspěvek z aplikované ekonomie; vychází z poznatků ekonomické teorie tam, kde je to z hlediska výkladu vhodné a nutné. Není knihou z oboru historie ani z pedagogiky, resp. andragogiky, s nimiž však se v mnoha směrech stýká a jejichž poznatků místy využívá. Není učebnicí ani jinou pedagogickou pomůckou a není primárně určena pro pedagogické účely. Právní problematika nebyla předmětem zkoumání, avšak tam, kde to bylo považováno za nezbytné, obsahuje odborná kniha potřebné odkazy na právní předpisy. Pro přehled právních předpisů o vzdělávání dospělých nutno odkázat na archiv Ministerstva spravedlnosti. Z akademické literatury lze využít publikace Možná, M., 2015.

Blok 3

Zařazení knihy do mezinárodní klasifikace

Podle klasifikace JEL lze publikaci zařadit takto:

A2. Economic Education and Theory of Economics: A29 (other);

B2. History of Economic Thought since 1925:

B29 (other); I. Health, Education and Welfare: I22 Educational Finance.

Podle číselníku oborů (Frascati): 50000-Social Sciences, 50300 (5.3 Education-50301).

\subsection{Prameny}

Tato podkapitola se zabývá třemi otázkami: výběrem pramenů (2.2.1), z nichž čerpá tato publikace, klasifikací těchto pramenů (2.2.2) a hodnocením jejich použitelnosti (2.2.3).

\subsubsection{Výběr pramenů}

Výběr pramenů byl proveden tak, aby odpovídal předmětu zkoumání, účelu a poslání této odborné knihy (2.1.1).

Autor prováděl výběr pramenů s ohledem na skutečnosti uvedené výše sub 2.1.

Některé citované prameny pocházejí z neveřejných zdrojů. Většinou jsou citovány z publikací BCPP nebo $\mathrm{z}$ autorova soukromého archivu. Prameny nepublikované tiskem jsou cyklostylované dokumenty (většinou opatřené datem, popř́padě jednacími čísly). Část tištěných českých, resp. zahraničních publikací (obvykle z let 1990-1992) nemá uvedenu značku ISBN (zejména tehdy, jde-li o zájmové publikace různých organizaci, např. bank). O jejich zařazení mezi prameny této knihy rozhodoval jejich věcný obsah, umožňující hlouběji pochopit důvody rozhodnutí přijatých různými orgány nebo osobami.

\subsubsection{Klasifikace pramenů}

Při zpracování této publikace autor při selekci pramenů využíval vlastní pracovní klasifikaci: 1. Úřední dokumenty; 2. Statistiky; 3. Knižní publikace (v češtině, v jiném jazyce; původní práce, překlady); 4. Časopisy (české; zahraniční); 5. Denní tisk (český; zahraniční); 6. Zákony; 7. Výroční zprávy společností; 8. Jiné (rozhovory, prohlášení aj.).

\subsubsection{Hodnocení použitelnosti pramenů}

Použité prameny byly prioritně posuzovány podle jejich použitelnosti:

1. věrohodnost informací (a. původní dokumenty, b. kopie dokumentů); 
2. úplnost informací (a. úplné, b. neúplné);

3. kompatibilita informací s analogickými nebo podobnými informacemi převzatými z pramenů týchž institucí (a. kompatibilní, b. nekompatibilní);

4. použitelnost informací (a. veřejně použitelné, b. zčásti modifikované nebo anonymní, tj. veřejně nepoužitelné);

5. vztah $\mathrm{k}$ událostem na kapitálovém trhu a $\mathrm{v}$ oblasti výzkumu. Výběr pramenů byl proveden $\mathrm{s}$ ohledem na současné právní předpisy o autorských právech.

Konečný výběr pramenů (kromě výše uvedeného omezení rozsahu publikace) narážel na řadu objektivních překážek, mezi něž lze - jako př́klady - uvést zejména tyto skutečnosti: 1. Pod názvy pramenů vyhledaných v bibliografických záznamech s přesně citovaným rokem vydání byly uvedeny pozdější roky vydání týchž publikací (nap̌r. u výroční zprávy MŠMT z r. 1997 byl uveden text výroční zprávy z r. 2001;2. V několika případech byla pod bibliografickými údaji o dané publikaci připojena poznámka „Missing. The text was probably hacked.“ 3 . V reklamách různých vydavatelství často nebyly zveřejněny údaje potřebné $\mathrm{k}$ citaci publikace bud' vůbec (!), nebo byly zkresleny. Jako konkrétní případ lze uvést Učitelské noviny, roč. 97, č. 42.

$\mathrm{V}$ několika případech sice bylo možno nalézt hledanou publikaci $\mathrm{v}$ cizojazyčném překladu, avšak nikoliv $\mathrm{v}$ českém originále. Tyto nedostatky $\mathrm{v}$ některých př́padech vedly $\mathrm{k}$ tomu, že některé závěry nebo některá hodnocení, obsažená v pozdějších pracích zabývajících se podobnými tématy, vydaných po $\mathrm{r}$. 2001, nelze považovat za přesná, nebot' nejsou doložena relevantními prameny publikovanými v letech 1990-1997.

Při podrobnějším výzkumu, spojeném $\mathrm{s}$ návštěvami archivů různých knihoven, by pravděpodobně bylo možno dohledat chybějící prameny, avšak pro tuto knihu nebylo hlubší pátrání z objektivních důvodů možné. Není však vyloučeno, že došlo ke skartaci některých dokumentů nebo k odmítnutí přístupu k některým dokumentům na základě Archivního zákona č. 343/1992 Sb. (Zákon České národní rady, kterým se mění a doplňuje zákon České národní rady č. 97/1974 Sb., o archivnictví). Tento zákon byl novelizován až po r. 1990.

\subsection{Metody výzkumu}

V této subkapitole (2.3) jsou uvedeny zejména informace relevantní pro odůvodnění volby aplikovaných výzkumných metod. Subkapitola (2.3) má dvě části: použité metody (2.3.1); metody zkoumání a postup výkladu (2.3.2).

\subsubsection{Použité metody}

Metodologie výzkumu charakterizovaná v tomto odstavci odpovídá předmětu zkoumání, účelu a poslání této odborné knihy (viz výše sub 2.1 a 2.2). V publikaci bylo využito jak běžného instrumentaria kvalitativního výzkumu, tak i nástrojů kvantitativního výzkumu.

\subsubsection{Metody zkoumání a postup výkladu}

Vzhledem k vymezení předmětu zkoumání a účelu této odborné knihy v ní převládají metody kvalitativního výzkumu. Jejich aplikace byla mj. podmíněna různorodou povahou zpracovaných pramenů, které bylo nutno roztřídit (podle kritérií uvedených v subkapitole 1.3) a vyhodnotit jejich použitelnost $\mathrm{z}$ hlediska $\mathrm{k}$ jejich vztahu $\mathrm{k}$ relevantním událostem $\mathrm{v}$ oblasti kapitálového trhu a finančního vzdělávání. 
U jednotlivých kapitol - pokud to bylo možné z hlediska povahy pramenů a z hlediska postavení dané kapitoly ve struktuře knihy - byl zachováván jednotný postup výkladu: nejprve byl popsán obsah kapitoly a její členění na subkapitoly. V jednotlivých subkapitolách byla provedena deskripce obsahu, poté zařazení zkoumaného obsahu do kontextu s ostatními částmi práce, ve vhodných př́padech provedena také klasifikace, a pak následoval rozbor. Na konci kapitol byla provedena syntéza zjišsěných poznatků a formulováno závěrečné Shrnutí obsahu dané kapitoly, které se stalo podkladem pro analýzu a pro formulaci výsledků, jejich prrípadnou generalizaci a syntézu.

Výklad byl uspořádán tak, aby hlavní text byl doplněn o důležité dílčí informace a o konkrétní př́klady, a to jednak ve formě tzv. exkurzů (celkem 5), jednak tzv. bloků (celkem 12). Tyto odbočky od hlavního textu obsahují komplementární důvody, proč některé důležité události (uvedené v kap. 1) nastaly. Spolu s některými dokumenty představují specifický „důkazní materiál“", dokládající některé závěry obsažené v hlavním textu.

V knize byla př́ležitost uplatnit statistické metody velmi omezena tím, že disponibilní data z oblasti vzdělávání v kapitole 9 byla neúplná. Proto mohlo být zpracováno pouze několik vlastních tabulek. Jiné statistické údaje byly vesměs čerpány z veřejných pramenů.

\section{Shrnutí}

Ve 2. kapitole se vychází z obecného východiska, že finanční vzdělávání a jeho úroveň je nezbytnou podmínkou pro efektivní fungování kapitálových trhů. Finanční investování vyžaduje, aby účastníci trhu měli nejen všeobecné základní vzdělání (tj. aby uměli číst, psát a počítat), ale aby také měli speciální finanční znalosti a dovednosti, nezbytné k účasti na kapitálovém trhu jako velmi významné součásti finančního trhu. Tento požadavek odpovídá stanoviskům mezinárodních organizací z 90. let minulého století (UNESCO, OECD aj.).

Kapitálový trh plní v rámci finančních trhů specifické funkce a jeho rozvoj je podmíněn stavem a vývojem reálné ekonomiky, zejména jejího finančního sektoru.

Prameny této publikace byly vyhledávány tak, aby napomáhaly ke splnění jejímu poslání. Z omezení záběru této knihy na mimoškolní finanční vzdělávání dospělých je zřejmé, že výběr pramenů nutně musel být selektivní. Hlavním kritériem selekce byl vztah daného pramene informací $\mathrm{k}$ výše vymezenému účelu této knihy. Prioritu měly prameny s přímou souvislostí $\mathrm{k}$ předmětu zkoumání. Vedlejším kritériem selekce byla míra významnosti obsahu daného pramene pro pochopení zkoumaných souvislostí. Některé prameny mají podpůrnou povahu, i když nemusely být vybrány jako prameny primárního charakteru. Byla snaha při selekci pramenů zachovávat nezbytnou objektivitu.

Některé citované prameny pocházejí z neveřejných zdrojů. Většinou jsou citovány z publikací BCPP nebo z autorova soukromého archivu. Publikace IPRFT nebo CMI, pokud byly určeny pro neveřejné účely, nemají ISBN.

Metodologie výzkumu aplikovaná v jednotlivých kapitolách této odborné knihy byla volena tak, aby odpovídala účelu/poslání této knihy. V publikaci bylo využito běžného instrumentaria kvalitativního výzkumu a v omezené míře také nástrojů kvantitativního výzkumu. 
Koncepce této odborné knihy vychází z možnosti a účelnosti několika odlišných způsobů prístupu k analýze zkoumaných otázek. V souladu s volbou metody vícevrstevnatého prístupu je obsah knihy rozčleněn do 10 kapitol.

První vrstvu výkladu - úzce spjatou s Úvodem - tvoří přehled hlavních událostí v oblasti kapitálového trhu a v oblasti finančního vzdělávání dospělých (v kap. 1); na ni navazuje technická kap. 2, která obsahuje informace o náležitostech vyžadovaných platnými předpisy pro odborné knihy. Druhá vrstva výkladu se zabývá některými základními pojmy, jejichž znalost je pro studium otázek finančního vzdělávání nezbytná (a to jak některých obecných, tak specifických pojmů týkajících se vzdělávání dospělých), a rovněž mezinárodním kontextem, $\mathrm{v}$ jehož rámci byl v české původní akademické literatuře vývoj dané problematiky později zkoumán (kap. 3 a 4). Třetí vrstvou výkladu je prŕstup z pozice institucionálně-organizačního členění národního hospodářství ČSFR/ČR, v kapitolách 5-7, kde je zkoumána úloha ministerstva financí, centrální banky a burzy cenných papírů při formování finančního vzdělávání. Čtvrtá vrstva výkladu se soustřed’uje na roli mediální sféry (kap. 8). Pátá vrstva výkladu se převážně věnuje vývoji soukromého podnikání v oblasti profesního vzdělávání a jeho významu (kap. 9). 


\section{Základní pojmy}

Cílem této kapitoly je vysvětlit některé základní pojmy spojené obecně se vzděláváním a specificky s finančním vzděláváním a jeho úrovní.

Kapitola 3 se skládá ze tří subkapitol. V první subkapitole (3.1) je zdůrazněn význam odborné terminologie pro finanční vzdělávání a jeho úroveň a současně i pro vědecké bádání v této oblasti. Zmíněna je i otázka adekvátnosti překladů základních pojmů z cizích jazyků do češtiny. Poté je vysvětlen pojem „finanční vzdělávání“, „finanční vzdělanost (gramotnost)“ a jejich vzájemný vztah. Druhá subkapitola (3.2) rozebírá pojem finančního vzdělávání podrobněji a uvádí rovněž srovnání jeho pojetí v české odborné literatuře s jeho pojetím v dokumentech OECD. Třetí subkapitola (3.3) rozebírá pojetí finanční vzdělanosti a přináší analogická srovnání jako v předchozí subkapitole.

\section{1 Úvodní úvahy}

Předpokladem úspěšného zkoumání finančního vzdělávání a finanční vzdělanosti je vymezení pojmového aparátu, používaného v této oblasti. U některých pojmů se lze setkat s tím, že není obecné shody při jejich definování. Příčin je zde více, ale uved’me jen tři nejčastější: 1. podstata daného jevu (objektu, procesu atd.) dosud není dostatečně vědecky prozkoumána, takže jej lze (oprávněně) definovat odlišně; $v$ důsledku dalších objevů se dnešní definice daného jevu může změnit (což se běžně děje). 2. Ke „konfliktu“ různých definicí téhož jevu lze v téže době přistupovat $\mathrm{z}$ různých hledisek, zejména $\mathrm{z}$ pozice odlišných vědních oborů. 3 . Některé odlišné definice uvedené $\mathrm{v}$ textu (a s nimi i v nich použité pojmy) mohou pramenit $\mathrm{z}$ nedostatku potřebných jazykových znalosti uživatelů, nebo i ze snahy „zviditelnit“ nějaký vznikající, ale dosud neuznávaný obor (zejména na rozhraní různých oborů).

Souběžná existence různých definic nebo charakteristik téže skutečnosti může vést - a skutečně také často vede - k diskusím, které vnášejí do stavu poznání spíše nejistotu a chaos.

Důsledné používání odborné terminologie při vědeckém zkoumání je velmi důležité pro praktický vzdělávací proces. V oblasti finančního vzdělávání bylo ve zkoumaném období, kdy česká odborná finanční terminologie teprve vznikala, nutno obsahově správně v českém jazyce vystihnout podstatu fungování finančních nástrojů, zaváděných v ČR ze zahraničí. ${ }^{4}$

Na tomto místě nutno připomenout, že evropské vzdělávací systémy v minulosti vznikaly v odlišných podmínkách $\mathrm{v}$ jednotlivých evropských zemích a dodnes se v řadě ohledů - i přes významné výsledky integračních snah (především pod vlivem Evropské unie) - odlišují. Školské soustavy v evropských zemích se např. liší délkou povinné školní docházky, pojetím jejích cílů, odlišným vymezením obsahu vyučovaných předmětů, a mnoha dalšími parametry. Mechanické porovnávání různých typů školských institucí nebo obsahu výuky, s nímž se dodnes lze setkat v tisku nebo i při rủzných odborných diskusích, je mnohdy zavádějící.

Významným historickým mezníkem pro rozvoj vzdělávacích soustav ve světě se po 2 . světové válce stal vznik OSN a řady dalších mezinárodních organizací a institucí. Otázka vzdělávání

\footnotetext{
${ }^{4}$ Určitou představu o rodící se terminologii vzdělávání (z pohledu andragogiky) lze získat z publikace Z. Palána „Andragogický slovník“ (Palán, 1997).
} 
zaujala významné postavení mezi uznávanými civilizačními a kulturními hodnotami a právo na vzdělání bylo zakotveno mezi lidskými právy v různých mezinárodních dohodách.

Zakotvení práva na vzdělání úzce souviselo s výsledky 2 . světové války. K jeho deklarování de facto došlo v důsledku dlouhodobé tendence vývoje vedoucí ke vzniku řady samostatných států, zejména bývalých kolonií předválečných koloniálních mocnosti. Zároveň ekonomicky vyplývalo z potřeb rozvoje 3. průmyslové revoluce. Oba tyto faktory spolu úzce souvisí: rozvoj průmyslu v hospodářsky málo vyvinutých zemích vyžadoval, aby pracovní síla vtažená do industrializačního procesu nebyla zcela negramotná, tj. aby se v rámci základního vzdělání naučila alespoň číst, psát a počítat. ${ }^{5}$

Ve vyspělých zemích vedl rychlý technický pokrok ke zvýšení pozornosti o otázky vzdělávání. V těchto zemích došlo jak k výraznému pokroku voblasti školství, tak ve vědeckých výzkumech, včetně pokroku v oblasti pedagogických věd. Po 2. světové válce např. došlo $\mathrm{k}$ důležitému rozlišení mezi základní gramotností spočívající v ovládání čtení a psaní a mezi vyššími stupni gramotnosti. Postupně vznikaly systémy měření úrovně vzdělanosti a pokusy o mezinárodní srovnávání úrovně vzdělanosti ve světě. Na počátku 90. let minulého století v ČSFR a později (po rozdělení Československa) v ČR se uvolnil prostor pro rozvoj školské soustavy v podmínkách ekonomické transformace spojené $\mathrm{s}$ přechodem k tržní ekonomice. Vznikl i nový prostor pro orientaci vzdělávání dospělých a jejího postupného odpoutání od marxistické ideologie.

Vzdělávání dospělých představuje velmi složitý problém. Po roce 1990 se vzdělávání dospělých ocitlo v nových složitých podmínkách spojených s možností soukromého podnikání v této oblasti. I když se stát snažil zachovat nad školskou soustavou kontrolu (v řadě ohledů formální), v oblasti vzdělávání dospělých převládl spíše neregulovaný a chaotický vývoj. Fakticky pod kontrolou státu zůstávala oblast kvalifikačních a rekvalifikačních kurzů, kde si tuto kontrolu vynucovaly potřeby národního hospodářství (mj. přesuny pracovní síly mezi odvětvími, vznik nezaměstnanosti a nutnost jejího řešení, problém kvalifikace a rekvalifikace státních zaměstnanců), spojené s nutností alokace finančních prostředků. I když tyto problémy nejsou předmětem zkoumání, pro pochopení dalších kapitol je rámcová znalost vývoje vzdělávání ve sledovaném období užitečná, což je většinou řešeno odkazy na literaturu. ${ }^{6}$

Nelze se zde nezmínit o tom, že v zahraničí byl pojem „vzdělání“ nebo pojem „dospělá osoba“ vymezován $\mathrm{v}$ různých zemích různě. Činnost nových mezinárodních organizaci jako je

\footnotetext{
${ }^{5}$ Deklarovat právo na vzdělání a skutečně vzdělávání zabezpečovat však není totéž. Není od věci připomenout, že snaha mezinárodních organizací podporovat vzdělávání co největšího počtu negramotných se ve 2 . polovině minulého století po několik desetiletí soustřed’ovala právě na skupinu hospodářsky málo vyvinutých zemí (cca 1215 zemí). Bez mezinárodní podpory by tyto země nebyly schopny absorbovat technické vymoženosti 20. století a staly by se brzdou procesu globalizace. Ze zkušenosti je známo, že prostředků na financování vzdělávání nikdy není dost. Odtud pramení eticko-filozofické úvahy, zda lze dosáhnout toho, aby se existující nůžky mezi chudobou a bohatstvím dále nerozevíraly, resp. jak dosáhnout alespoň zpomalení tohoto procesu. (Na Vysoké škole finanční a správní je v současné době k uvedenému tématu připravován výzkumný projekt. Č́st autorových poznámek $\mathrm{z}$ r. 2019 k tomuto projektu je uvedena v Př́loze.)

${ }^{6}$ Užitečnou pomůckou jsou zejména práce o historickém vývoji vzdělávání ve světě a jeho specifickém vývoji v různých zemích, které čtenáři umožní základní orientaci a vytváření jeho vlastního názoru na tuto otázku. Ze zahraniční literatury lze doporučit např. Jackson, 1973; OECD (2017) - G20/OECD INFE report; SIALS 1998; Agenda pro budoucnost [online], Hamburk 1997; Jomtienská deklarace [online]. Jomtien, 1990; Analýza občanského vzdělávání dospělých, 2010 aj.
} 
UNESCO, OECD aj., se rozvíjela jen postupně. ${ }^{7}$ Lze konstatovat, že z pozice OSN byla snaha zpočátku soustředit pozornost na zvýšení základní gramotnosti mládeže a snižování negramotnosti velké části dospělého obyvatelstva $\mathrm{v}$ hospodářsky méně vyvinutých zemích (zejména $\mathrm{v}$ bývalých koloniích bývalých koloniálních mocností).

Pokud jde o vyspělé země, od šedesátých a sedmdesátých let v těchto zemích primárně nešlo pouze o snahu o vymýcení úplné negramotnosti, ale o podporu zvyšování celkové úrovně gramotnosti (včetně úrovně profesního vzdělání a také úrovně vzdělávání dospělých). ${ }^{8}$

Přijatelné a v praxi aplikovatelné vymezení pojmu „dospělá osoba“ je komplikováno mj. tím, že jednotlivá kritéria pro určení tohoto pojmu jsou stanovována z různých aspektů a rovněž tím, že se hlediska vymezená $\mathrm{z}$ různých aspekti̊ mohou navzájem překrývat.

V teorii (a její aplikaci v praxi) se zpravidla lze setkat s těmito hledisky vymezení pojmu „dospělá osoba“"(,dospělý‘):

1. kritérium věku, tj. počtu dožitých let $\mathrm{k}$ danému okamžiku, kdy je toto stanovení prakticky relevantní pro přiznání nějakých nároků dané osoby. Věk bývá vymezován jako uzavřené období (např. 18-64 let), tj. jako rozmezí mezi nejnižší a nejvyšší hodnotou, nebo může být stanoven jako otevřené období, tj. jako minimální věková hranice bez vymezení horní hranice věku (de facto až do smrti dané osoby).

2. kritérium vztahu věku po dosažení určitého vzdělání do vstupu do prvního zaměstnání;

3. kritérium výkonu povolání po ukončení základního nebo univerzitního vzdělání;

4. kritérium ověření dosažené kvalifikace nebo rekvalifikace po dosažení minimální hranice věku (viz sub 1), nebo po dosažení maximální hranice věku;

5. kritérium zaměstnanosti, tj. zjištění, zda jde o osobu zaměstnanou nebo osobu vedenou jako nezaměstnanou. ${ }^{9}$

\footnotetext{
${ }^{7}$ Z obrovského počtu různých publikací těchto organizací bylo možno pro tuto publikaci vybrat jen nemnohé. Vesměs jsou citovány k ilustraci názorů nebo stanovisek těchto organizací k otázkám vzdělávání.

${ }^{8} \mathrm{~S}$ rostoucí migrací obyvatelstva ve světě stoupá význam požadavku, aby přiznání občanství v dané zemi bylo vázáno na určitou úroveň znalosti jazyka dané země. Zanedbání tohoto požadavku vede při nelegální migraci ke koncentraci negramotného obyvatelstva v tzv. ghettech velkoměst, což ve většině zemí, kde žijí nelegální migranti, bývá zdrojem napětí, zločinnosti a dalších negativních jevů.

9 Toto schéma může být $\mathrm{v}$ různých zemích modifikováno jinými př́istupy nebo kombinací výše uvedených pěti možností (viz též Kirsch, 2001). Diskuse o vymezení pojmu dospělosti se v různých zemích opakují v souvislosti se změnami vzdělávacích soustav, s aplikací moderních technologií do výuky, a bývají podmíněny i řadou jiných faktorů (např. členství dané země v mezinárodních organizacích apod.)
} 


\section{Graf 1}

\section{Myšlenková mapa 5 kritérií př́ístupů k pojetí dospělosti}

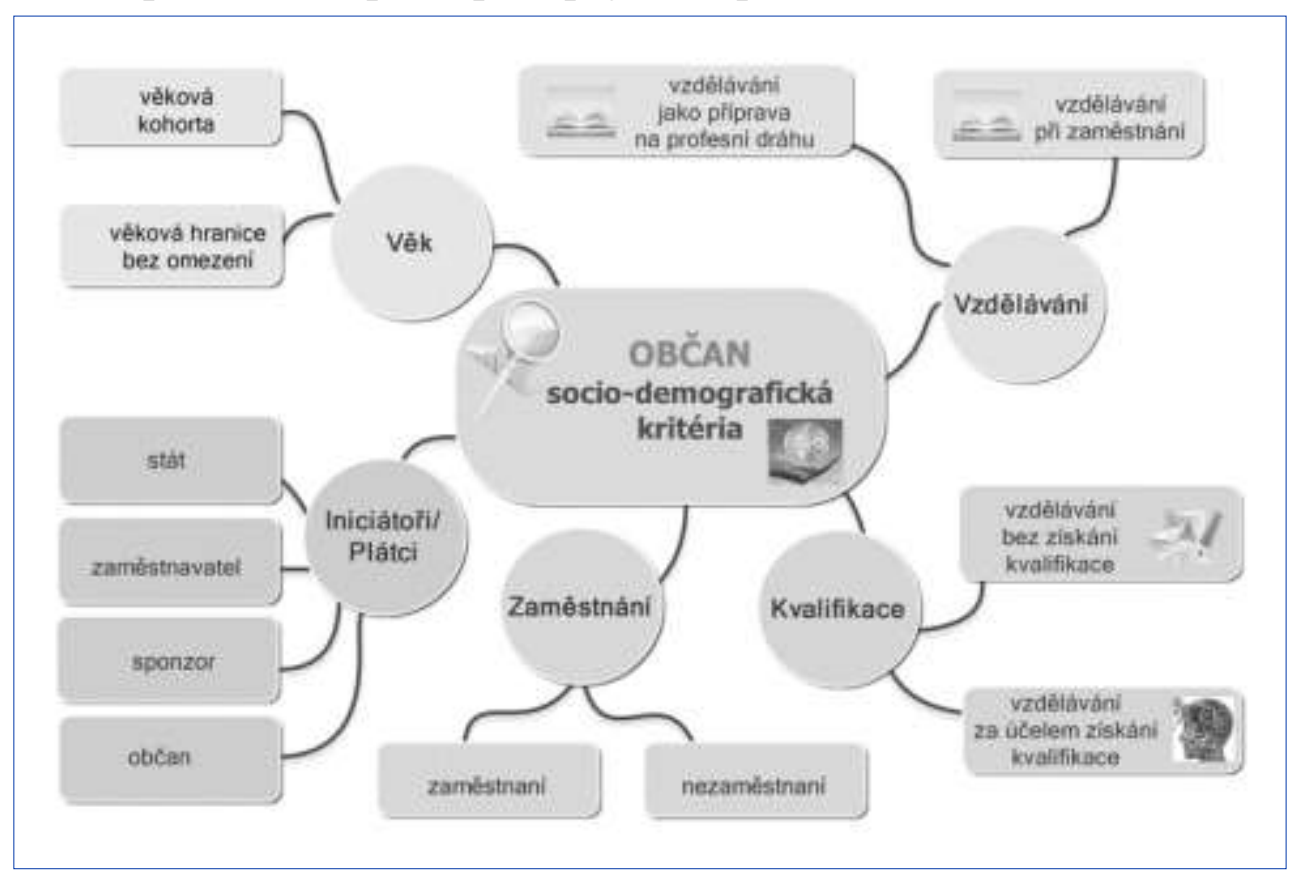

Pro pojetí vzdělávání dospělých je důležité pokusit se vymezit relevantní kritéria, umožňující rozlišit a porovnávat různá pojetí vzdělávání dospělých v různých zemích, a to jak v období sledovaném v této knize (tj. 1990-1997), tak v pozdějších letech. Samostatná srovnávací studie tohoto druhu by mohla být užitečná pro hodnocení míry integračních procesů v EU.

Při konstrukci výše uvedené myšlenkové mapy měl autor snahu omezit počet relevantních kritérií na 5: 1. vymezení pojmu „dospělost“", 2. charakter vzdělávacího procesu a jeho účel $\mathrm{s}$ ohledem na časovou souvislost mezi dovršením dospělosti a prvním zaměstnáním, 3. cíl vzdělávacího procesu ve vztahu k profesní kvalifikaci, 4. fenomén reálného praktického uplatnění získaného vzdělání ( $t j$. př́ípadného rizika nemožnosti uplatnění dosaženého vzdělání), 5. rozlišení potenciálních iniciátorů vzdělávacího procesu a jejich postavení jako nositele nákladů na vzdělání.

Mezi pěti hledisky, uvedenými před myšlenkovou mapou výše, a autorovým vymezením relevantních hledisek v předchozím odstavci, je rozdíl jednak v tom, že do prvního výčtu není zahrnuto hledisko nákladů na financování vzdělávacího procesu, jednak v odlišném vymezení obsahu jednotlivých hledisek. První klasifikace klade důraz na vztahy vzdělávacího procesu s jeho orientací a využitím (viz výše body 2-5). Druhá klasifikace tyto 4 vztahy redukuje na 3 a přibírá hledisko financování nákladů na vzdělávací proces jako národohospodářsky relevantní.

Společným rysem obou schémat je to, že praktická realizace vytyčených kritérií je podmíněna jejich zakotvením $\mathrm{v}$ právních předpisech. Tyto předpisy ideově a hodnotově vycházejí z ústav demokratických států, které se za současného stavu vzájemně liší.

Odlišnost ústavních předpisů a právních soustav je podmíněna mnoha faktory, zejména odlišnostmi historického vývoje (včetně vývoje struktury národního hospodářství), odlišnou 
demografickou, sociální, etnickou, kulturní, náboženskou atd. strukturou, která prochází různými změnami.

V České republice např. jde o větší počet důležitých právních předpisů, zejména o občanský zákoník, zákoník práce, předpisy týkající se různých forem a stupňů vzdělávaní (např. o základním vzdělávání, o vysokoškolském vzdělávání, o specifických formách profesního vzdělávání apod.), předpisy sociální a zdravotní, předpisy týkající se zaměstnanosti a nezaměstnanosti aj. Bez právní analýzy nelze přesněji určit, ke kterým kritériím se jednotlivé předpisy vztahují. ${ }^{10}$

Pokud jde o strukturu a úroveň vzdělanosti v ČR, složitost realizace vzdělávání dospělých během 90 . let mimo jiné souvisí se skutečností, že se otevřely možnosti publikovat překlady prací zahraničních autorů z oblasti vzdělávání do češtiny, a to při neexistenci adekvátní interpretace cizojazyčné odborné terminologie. ${ }^{11}$

Pro praktické účely má značný význam rozlišení vzdělávacích subjektů (institucí) podle jejich vlastnictví. Z tohoto hlediska obvykle lze rozlišit: 1 . subjekty státní; 2 . subjekty soukromé; 3 . subjekty se smíšeným vlastnictvím. V jednotlivých zemích se vzdělávací soustavy liší, což je spojeno s odlišnou kategorizací daných subjektů. Tato skutečnost má značný vliv na financování vzdělávacích subjekti̊. Mezinárodní srovnávání nákladů na různé kategorie vzdělávacích subjektů je proto obtížné. ${ }^{12}$

Velmi frekventovaný problém představuje klasifikace typů (druhů, forem) vzdělávání, resp. vzdělávání dospělých. Jako př́iklad dále uvádíme (v bloku 6) tři možné přístupy k typologii vzdělávání. ${ }^{13}$

Vzdělávání dospělých - jako jeden z důležitých druhů vzdělávání - různí autoři v české literatuře $\mathrm{v}$ druhé polovině 90 . let a $\mathrm{v}$ letech pozdějších definovali odlišně. Jednou ze známějších definic je Palánova definice z r. 2002.

Nyní stručné (avšak nezbytné) odbočení do oblasti filologie. Mnohé pojmy v oblasti finančního vzdělávání byly v minulosti z cizích jazyků (hlavně z angličtiny, ale i z jiných evropských jazyků) přejímány do českého jazyka živelně, často bez dostatečné znalosti daného cizího

\footnotetext{
${ }^{10}$ Analýza by mohla přinést možnost hlouběji posoudit povahu vztahů mezi reálnou situací v oblasti jednotlivých forem vzdělávání a stavem právní úpravy. Mezinárodní srovnání může přispět ke snížení časové prodlevy (timelag) mezi zjištěnou potřebou změny relevantních právních předpisů a jejich aplikací v praxi.

${ }^{11}$ Naši spoluobčané, kteří si během základní školské docházky neosvojili žádný světový jazyk, aby mohli př́padně studovat i v cizím jazyce, jsou při dalším studiu ve srovnání napřs. se studenty gymnázií znevýhodněni. Určitou bariéru také představují náklady na studium dospělých př̌i zaměstnání.

${ }^{12}$ Někteří čeští autoři uvádějí odlišná členění tzv. aktérů, tj organizací a institucí činných ve sfeěre vzdělávání dospělých. Např. B. Říhová do kategorie státem financovaných aktérů řadí vládu a samosprávy. Ve skupině soukromých aktérů rozlišuje tři typy aktérů. Jsou to: 1. sociální partneři (zaměstnavatelé a odbory); 2 . profesní sdružení (např. Česká bankovní asociace); 3. média a sociální sítě (mezi média řadí také veřejnoprávní televizi, což protiřečí volbě základního kritéria - členění na subjekty státní a soukromé). Odlišnou dílčí klasifikaci aktérů uvádí napřs. E. Tylšarová (viz dále). Z jiné pozice se vzděláváním dospělých zabývala $H$. Vychová, která je zkoumala jako podmnožinu celoživotního učení (Vychová, 2008). Některé z těchto klasifikací nejsou z teoretickometodologického hlediska podloženy předem vymezenými kritérií a nejsou vzájemně srovnatelné.

${ }^{13}$ Jiným příkladem tř́idění druhů vzdělávání dospělých je členění E. Tylšarové na profesní, občanské a zájmové (Tylšarová, 2014).
} 
jazyka. Negativní roli zde v minulosti (a bohužel často také dnes) sehrála snaha novinářŭ, jak daný nový pojem co nejrychleji přiblížit českému čtenáři. U některých pojmů se to vyřešilo tím, že určitý výraz vůbec nebyl přeložen, nýbrž pouze přepsán v angličtině. Názorným prŕíladem takového postupu je např. slovo „blog“, které se poměrně nedávno velmi rychle uhnízdilo v internetové češtině. Stěži lze pochybovat o tom, že kdyby osoby, které pojem neuměly přeložit, nejdříve pohlédly do slovníku, zjistily by, že jeho význam nemusí být právě lichotivý pro toho, kdo jej používá.

V odborné ekonomické literatuře - včetně literatury finanční - je situace obdobná: existuje v ní mnoho nepřeložených výrazů, které se prostě do odborné terminologie z různých důvodů vplížily, a zůstávají v ní zachovány.

Nyní stručně k definicím pojmů „finanční vzdělávání“ a „,finanční vzdělanost“, které v 90. letech minulého století v souvislosti s transformačním procesem vstoupily do vědomí lidí.

V běžné laické konverzaci dosud často dochází $\mathrm{k}$ nepřesnostem $\mathrm{v}$ chápání a $\mathrm{k}$ časté záměně obou výše zmíněných pojmů, které předtím na 40 let téměř vymizely z běžného českého slovníku.

V této knize je pojem „education“ (resp. financial education) překládán nikoliv jako „vzděláni““, nýbrž jako „vzdělávání (tj. gramaticky jde o nedokonavý vid slovesný): v tomto pojetí tedy jde o nekončící proces nabývání vědomostí učením, tj. o dynamický proces. Naopak posuzujeme-li výsledek vzdělávacího procesu k určitému časovému okamžiku, jde o dosaženou míru vzdělanosti, tj. o stavovou veličinu.

V 90. letech se s pojmem „finanční gramotnost“ (z anglického „financial literacy“) v české literatuře lze setkat jen výjimečně: běžně se psalo o finančních znalostech, o rozsahu nebo úrovni finančních znalostí apod. ${ }^{14}$

Pojem „finanční gramotnost“, který vznikl překladem anglického „financial literacy“, začal být běžněji užíván pro zjištění, že děti a mladiství ve školách se sice celkem snadno a úspěšně brzy naučí číst a psát (a mnozí z nich již v předškolním věku), avšak s počítáním jim to často tak dobře nejde. Tento stav - určitá nechut' k matematice - bohužel do určité míry přežívá dodnes; bude trvat dlouho tento syndrom postupně překonávat. Přitom je nasnadě, že téměř každý dospělý člověk se v životě setkává s nutností při vlastním finančním rozhodování sám posoudit, zda daná finanční operace pro něho je výhodná nebo nikoliv. ${ }^{15}$

Teprve poměrně pozdě v 90 . letech do ČR postupně přicházely moderní poznatky z oblasti školního a mimoškolního finančního vzdělávání a došlo k tomu, že si úřady - po dlouhé době - uvědomily naše zaostávání.

\footnotetext{
${ }^{14}$ Např. M. Možná celoživotní vzdělávání interpretovala (z anglického continual learning) jako „učení“ (Možná, 2015). K otázce gramotnosti byla po r. 2000 vydána řada zajímavých prací (viz např.: Rabušicová, 2002; Hodinová, 2013; Vychová, 2008; Pospíśil, R., 2010 aj.).

${ }^{15}$ Spoléhat se na pomoc jiných osob často nebývá bezpečné. Naopak pro mnohé lidi bývá př́iležitostí k páchání podvodů (viz též Wawrosz, 2017).
} 
První výraznější zlepšení ve školské oblasti nastalo poté, když v r. 2010 byla vypracována první „Národní strategie finančního vzdělávání“, kterou schválila česká vláda (viz dále 3.3.2). Tento dokument byl připravován po dobu zhruba tř́ let. ${ }^{16}$

V české odborné literatuře o vzdělávání nebývají používané pojmy aplikovány a interpretovány jednotně. ${ }^{17}$

O finančním vzdělání, resp. o finanční gramotnosti pojednávají různé vědní disciplíny, označované názvy pedagogika, andragogika aj. Každá z nich si do určité míry modifikuje terminologii vztahující se k finančnímu vzdělávání pro potřeby daného oboru.

Blok 4

\section{Andragogika}

Andragogika bývá charakterizována jako pedagogická disciplína zabývající se výchovou a vzděláváním dospělých. Tato stručná encyklopedická charakteristika, jejímž autorem ve slovníku cizích slov (ABZ.cz) je jeden z významných českých představitelů této disciplíny Milan Beněs, je jednou z mnoha existujících definic andragogiky. Andragogika někdy bývá definována např. jako vědní a studijní obor zaměřený na veškeré aspekty vzdělávání a učení dospělých.

V jednom ze zahraničních široce uznávaných slovníků, jakým je např. slovník britské univerzity v Cambridgi, je andragogika definována jako „teorie, metody a aktivity zapojené do výuky dospělých studentü“ (,andragogy definition: the theory, methods and activities involved in teaching adult learner". Cambridge English Dictionary, 2019). Ve slovníku Merriam-Webster je definována jako „umění nebo věda o výuce dospělých“. („Andragogy definition is the art or science of teaching adults." Merriam-Webster Dictionary. Andragogy definition, 2019.)

Naproti tomu výraz „pedagogika“ v ČR bývá chápán jako výchova a vzdělávání mládeže (ačkoliv to - podle názoru některých českých odborníků - není přesné). V anglickém slovníku Thesaurus.com lze nalézt toto vysvětlení rozdílů mezi pedagogikou a andragogikou: ,You can conclude from the above that pedagogy is a child-focused teaching approach, whereas andragogy an adult-focused teaching approach; or, formally, pedagogy is the art and science of helping kids learn, whereas andragogy is the art and science of helping adults learn." (Thesaurus.com, 13. 11. 2015.)

\footnotetext{
${ }^{16}$ Původní materiál „Strategie finančního vzdělávání“ vypracovalo v roce 2007 MF ve spolupráci s MŠMT a MPO. Po schválení vedením MF a MŠMT se stal základem pro další kroky ve finančním vzdělávání popsané v kapitole 2. (Viz též USNESENÍ VLÁDY ČESKÉ REPUBLIKY ze dne 10. května 2010 č. 338 o Národní strategii finančního vzdělávání.)

${ }^{17}$ Kromě toho se s nevšední vynalézavostí někteří autoři snaží běžnou terminologii doplnit novými výrazy ze svých dílen s chvályhodným úmyslem nahradit některé anglické názvy vhodným českým překladem. Uved’me jeden z př́ikladů: po konstatování, že anglická slova „background knowledge“, která bývají překládána jako „obecná znalost“ nebo „základní znalosti““(v poznámce pod čarou č. 6) autoři piśíi, že „žádný z českých překladů však původní anglický výraz nevystihuje zcela. V této publikaci se budeme držet termínu ,znalost pozadí, ačkoli může působit mírně nezvykle." (Analýza občanského vzdělávání dospělých, 2010.) Z výkladu plyne, že obsahem „pozadi“ je „znalost politických konceptů, filozofíi a významných historických událostí, předpoklady pro interpretaci současného dění“.
} 
Při klasifikaci věd bývá $\mathrm{v}$ české odborné literatuře pedagogika členěna na základní a hraniční vědy. V tomto schématu je andragogika řazena mezi tzv. hraniční vědy. V této souvislosti je v pracích některých českých odborníků vymezován vztah mezi andragogikou a př́ibuznými obory humanitních věd, např. psychologií a sociologií; vztah k ekonomickým vědám, zejména $\mathrm{k}$ disciplínám aplikované ekonomie nebývá vymezen, přestože by jeho vymezení pro oblast vědeckého výzkumu usnadnilo např. zařazování výsledků vědeckých prací do př́slušných oborů. (Viz též kap. 1 - Blok 1: Zařazení knihy do mezinárodní klasifikace.)

\subsection{Finanční vzdělávání}

Tato subkapitola je rozčleněna do dvou částí. V první části (3.2.1) pojednává o definici finančního vzdělání podle UNESCO. Druhá část (3.2.2) se zabývá definicí finančního vzdělávání v českých úředních dokumentech.

\subsubsection{Definice finančního vzdělávání v zahraničí}

V současné době existuje řada definic finančního vzdělání, které vypracovaly různé organizace. Mezinárodně uznávány jsou zejména definice publikované významnými mezinárodními organizacemi a/nebo institucemi. Některé z těchto definic jsou zde dále uvedeny jako prŕíklad (nejsou komentovány).

Mezinárodní organizace UNESCO se otázkami vzdělávání zabývá dlouhodobě od svého vzniku. UNESCO je jedinou $\mathrm{z}$ agentur OSN, která má mandát $\mathrm{k}$ tomu, aby se komplexně zabývala agendou vzdělávání. ${ }^{18}$

Jedna ze starších definic vzdělání (angl. education), které uvádí UNESCO, např. zní takto: „UNESCO věří, že vzdělání je právem člověka po celou dobu jeho života a přístup k němu musí být kvalitní.“"19

Jako př́klad encyklopedické definice lze uvést definici vzdělání uveřejněnou v Newworldencyclopedia:

„Vzdělání zahrnuje vyučování a učení se specifickým dovednostem (skills), a rovněž méně zjevným, ale hlubším schopnostem: specifickým dovednostem, pozitivnímu úsudku a dobře rozvinutým znalostem. Jedním ze základních aspektů vzdělání je přenášení kultury z generace na generaci ....ale více se týká formálního procesu vyučování a učení se, existujícího ve školním prostředí." (Newworldencyclopedia, 2019.) ${ }^{20}$

Finanční vzdělávání se realizuje také formou vzdělávání dospělých (adult education).

\footnotetext{
${ }^{18}$ Definice vzdělání používaná OECD je uvedena sub 2. (Definice finanční gramotnosti.)

${ }^{19} \mathrm{~V}$ anglickém originálu: „UNESCO believes that education is a human right for all throughout life and that access must be matched by quality.“

20 „Education encompasses teaching and learning specific skills, and also something less tangible but more profound: the imparting of knowledge, positive judgment and well-developed wisdom. Education has as one of its fundamental aspects the imparting of culture from generation to generation ..., yet it more refers to the formal process of teaching and learning found in the school environment."
} 
Slovník University Cambridge uvádí tuto definici vzdělávání dospělých (adult education): „,...vyučování pro lidi, kteří ukončili svou školní výchovu, obvykle nabývané proto, aby se naučili věcem, kterým se nenaučili ve škole.“ (Dictionary Cambridge) ${ }^{21}$

Britská encyklopedie (British Encyclopaedia) charakterizuje vzdělávání dospělých poměrně obšírně a zahrnuje do této charakteristiky také př́íklady rủzných druhů vzdělání (ve smyslu vzdělávání - V. P.) dospělých:

„Vzděláváním dospělých, označovaným také „pokračující další vzdělávání“ je každá forma učení, prováděného nebo zajišt'ovaného pro dospělé muže a ženy.“ Ve zprávě z r. 1970 Národního ústavu pro vzdělávání dospělých (Anglie a Walesu) je vzdělávání definováno jako „...jakýkoliv druh vzdělání lidí, kteří jsou dostatečně staří, aby pracovali, hlasovali, bojovali a uzavírali sňatky, a kteří ukončili cyklus kontinuálního vzdělávání, započatého v dětství (pokud nějakým cyklem prošli).“ Dále text pokračuje takto: „...Vzdělávání dospělých zahrnuje takové rozličné způsoby, jako je nezávislé studium vědomě uskutečňované v knihovnách s jejich pomocí nebo bez ní; rozhlasové programy nebo korespondenční kurzy; skupinové diskuse a jiné učení ve studijních kroužcích vzájemné pomoci, kolokvia, semináře nebo cvičení (v orig. workshops - V. P.) a rezidenční konference nebo schůze; a celodenní nebo polodenní studium v kurzech, v nichž má lektor nebo tutor formální vedoucí úlohu. “22

\section{Blok 5}

\section{Mezinárodní výzkum gramotnosti}

Evropská komise v Závěrečné zprávě skupiny odborníků EU pro gramotnost upozornila na
rozšířenou mylnou představu Evropanů o vyřešení gramotnosti: „Překvapivě vysoký počet
Evropanů má nedostatečnou úroveň gramotnosti. Z vnitrostátních a mezinárodních
průzkumů vyplývá, že zhruba jeden z pěti dospělých a jedno z pěti patnáctiletých dětí má
nedostatečné schopnosti související s porozuméním psanému textu, které jsou třeba k plnému
zapojení se do moderní společnosti.“ Toto konstatování se opírá o výsledky Mezinárodního
výzkumu gramotnosti dospělých (International Adult Literacy Survey - IALS),
organizovaného Organizací pro hospodářskou spolupráci a rozvoj (OECD) v roce 1994, kdy
bylpoužit nový metodologický přstup ke zjišt'ování gramotnosti s novým pohledem na obsah
termínu a kategorizování gramotnosti do pěti úrovní. I když je použit termín gramotnost, jde
již o posun významu tohoto slova do odlišných forem aktivity: vzniká termín „funkční
gramotnost“.
Zdroj: Skupina odborníků EU pro zkoumání gramotnosti. [online]. [cit. 2013-03-01].
Dostupné z: http://ec.europa.eu/education/literacy/what-eu/high-level-
group/documents/executive-summary_cs.pdf, str. 4

\footnotetext{
${ }^{21} \mathrm{~V}$ originále zní takto: ,...classes for people who have finished their school education, usually taken in order to learn things they failed to learn in school.“

${ }^{22}$ Adult education, also called continuing education, any form of learning undertaken by or provided for mature men and women. In a 1970 report, the Adult education, also called continuing education, any form of learning undertaken by or provided for mature men and women. In a 1970 report, the National Institute of Adult Education (England and Wales) defined adult education as "any kind of education for people who are old enough to work, vote, fight and marry and who have completed the cycle of continuous education, [if any] commenced in childhood." Adult education comprehends such diverse modes as independent study consciously pursued with or without the aid of libraries; broadcast programs or correspondence courses; group discussion and other "mutual aid" learning in study circles, colloquia, seminars or workshops, and residential conferences or meetings; and fullor part-time study in classes or courses in which the lecturer, teacher, or tutor has a formal leading role.
} 
Vzdělávání dospělých charakterizoval specifickým způsobem I. Kirsch v obsáhlé výzkumné zprávě ISCED (Kirsch, 2001). V jeho pojetí je za vzdělávání dospělých považována „každá organizovaná a trvalá komunikace určená $\mathrm{k}$ tomu, aby přinášela prospěch a přizpůsobená potřebám osob, které ukončily řádné školské a univerzitní vzdělání. Vyšší vzdělání po ukončení školského vzdělání v době předcházející vstupu na pracovní trh normálně není považováno za vzdělávání dospělých.“23

Jedním z důležitých zahraničních pramenů pro hlubší studium problematiky vzdělávání dospělých je publikace UNESCO (1996), v níž je mj. uveřejněna tzv. Delorsova zpráva, spolu s reprezentativním výběrem další zahraniční literatury (UNESCO. Learning: the treasure within. 1996. Reedice 2013, ISBN 978-92-3-001132-1).

\subsubsection{Definice vzdělání v ČR}

V 90. letech v ČR se běžně používalo výrazu „vzdělání“ (prríp. „vzdělávání) jako překladu anglického slova „education“. Tento pojem byl chápán ve smyslu výše uvedené definice UNESCO nebo obecně ve smyslu encyklopedických definic vzdělání (viz výše 2.2.1). Při úvahách o vzdělání uveřejňovaných v tisku v tomto období obvykle šlo o hodnocení úrovně (míry) všeobecného školského vzdělání různých vrstev obyvatelstva ČSFR a ČR ve srovnání s jinými (většinou evropskými) zeměmi.

Pokud šlo o znalosti z finanční oblasti, počátkem 90 . let se začalo běžně používat pojmů „finanční znalosti“, „finanční vzdělání“ apod. Česká terminologie týkající se finanční sféry, teprve postupně začala živelně vznikat (srov. 2.1; Předmluva). Žádná obecně uznávaná „oficiální““ definice finančního vzdělání tehdy ještě neexistovala.

Vzdělávání dospělých, jímž se tato kniha zabývá, prošlo v prvních třech letech před rozdělením Československa obdobím diverzifikace, kdy se v podstatě nekoordinovaně vzděláváním této skupiny obyvatelstva začal zabývat poměrně značný počet různých subjektů. ${ }^{24}$

V období let 1990-1997 byly mnohé představy o vzdělávání dospělých - eufemisticky řečeno - dosti matné, nesystémové a chaotické. Počínaje r. 1995-6 však - např. v souvislosti s kritikou nedostatků při obchodování cennými papíry - byly uveřejněny a diskutovány mnohé racionální návrhy na zlepšení vzdělávání dospělých i finančního vzdělávání dospělých (kap. 7 a 8). ${ }^{25}$

\footnotetext{
${ }^{23}$ „Any organized and sustained communication designed to bring about learning for the benefit, and adapted to the needs, of persons - who have completed regular school and university education. Higher and postschool education undertaken before entering the labour market is not normally considered to be adult education."

Anglický text dále cituje doporučení organizace UNESCO z r. 1976 k rozvoji vzdělávání dospělých, které doplňuje výše uvedenou definici: „,[In the UNESCO Recommendation on the Development of Adult Education (1976) the term denotes the entire body of organized educational processes, whatever the content, level and method, whether formal or otherwise, whether they prolong or replace initial education in schools, colleges and universities as well as in apprenticeship, whereby persons regarded as adult by the society to which they belong develop their abilities, enrich their knowledge, improve their technical or professional qualifications or turn them in a new direction and bring about changes in their attitudes or behaviour in the twofold perspective of full personal development and participation in balanced and independent social, economic and cultural development.]“

${ }^{24} \mathrm{~K}$ tomu viz kap. 8.1.

${ }^{25}$ Koncem 90. let - mj. pod dojmem kritiky OECD týkající se školské politiky a vzdělávací soustavy ČR - odborná veřejnost reagovala zvýšením zájmu o tyto problémy. Mezi zdařilé publikace té doby patř́ zejména „Bílá kniha“, v níž se poměrně velký autorský kolektiv snažil podat ucelenější názor na další vývoj českého školství. Součástí tohoto pohledu byly i otázky vzdělávání dospělých (nikoliv však specifické problémy finančního vzdělávání, kde
} 


\subsection{Finanční gramotnost}

Tato subkapitola je rozčleněna do dvou částí. První z nich (3.3.1) se zabývá pojetím finanční gramotnosti v dokumentech OECD. Druhá část (3.3.2) hodnotí účast ČR na průzkumu gramotnosti v rámci $\mathrm{OECD}$.

\section{90. letech v ČR pojem „finanční gramotnost“ (financial literacy) nebyl užíván (viz výše 2.1). Běžně se používalo výrazu ,finanční znalosti“, „finanční vzděláni'“. ${ }^{26}$}

Do odborného českého finančního slovníku se pojem gramotnosti definitivně dostal teprve v souvislosti s vypracováním, uveřejněním a naplňováním „Národní strategie finančního vzdělávání“ jako základního dokumentu, významného pro finanční vzdělávání školní mládeže, pro spotřebitele finančních produkti̊ a služeb a pro pracovníky finanční sféry. Tento dokument vznikl později jako výsledek jednání Pracovní skupiny pro finanční vzdělávání, složené ze zástupců Ministerstva financí ČR, Ministerstva průmyslu a obchodu ČR, Ministerstva školství a tělovýchovy ČR a České národní banky a ve spolupráci se spotřebitelskými a profesními organizacemi. Tento dokument byl jako koncepční dokument zpracován se znalostí a v souladu se zahraničními poznatky a prameny mezinárodních organizací.

Přijatá definice zněla takto: „Finanční gramotnost je soubor znalostí, dovedností a hodnotových postojů občana nezbytných $\mathrm{k}$ tomu, aby finančně zabezpečil sebe a svou rodinu $\mathrm{v}$ současné

diskuse po vzniku Komise pro cenné papíry po r. 1998 na několik letech ochabla a oživila se až v letech 20042007, tj. po vstupu ČR do EU). „Bílá kniha“ (Národní program rozvoje vzdělávání v ČR - Bílá kniha, 2001).

Bílá kniha se zabývala vzděláváním dospělých v posledním oddílu této publikace (oddíl IV.) V rámci pojednání o společných otázkách vzdělávání dospělých řešila pojetí tohoto vzdělávání jako integrální součásti vzdělávací soustavy a zabývala se i jeho klíčovými problémy (včetně návrhů na řešení). Dále pak nastínila specifické problémy vzdělávání dospělých včetně studia dospělých ve školách. V závěrech této studie byly shrnuty tehdejší nejaktuálnější problémy, které souvisely s dalším rozvojem školství (patřily mezi ně např. zabezpečení celoživotního učení pro všechny, kvalita a efektivita vzdělávání, vnitřní proměny a otevřenost vzdělávacích institucí, profesní perspektivy pedagogických a akademických pracovníků, přechod od centralizovaného rízení k odpovědnému spolurozhodování aj.) Většina navržených řešení směřovala $\mathrm{k}$ odstranění nedostatků, které byly analyzovány ve výše uvedené publikaci OECD. Na publikaci se podílelo na 40 autorů. Šlo o první kolektivní syntetickou práci, z níž se později zrodila první varianta koncepce národního vzdělávání v r. 2007 a její finální podoba v r. 2010. (Původní citace Bílé knihy byla datována rokem 1999; autor však pracoval s výše uvedenou verzí z r. 2001.) Znovu zde nutno zdůraznit, že řešení navrhovaná v Bílé knize byla do značné míry inspirována kritickými názory OECD. Tato významná organizace poskytla České republice významnou podporu tím, že se zasedání Výboru pro vzdělávání OECD na úrovni ministrů ve dnech 16-17. ledna 1996 konalo v Praze. Hlavním tématem tohoto zasedání se stala otázka celoživotního učení pro všechny. (Zpráva byla vydána v českém překladu v edici Gnosis Učitelských novin v r. 1997: OECD. Celoživotní učení pro všechny. Zasedání Výboru pro vzdělávání OECD na úrovni ministrů ve dnech 16-17. ledna 1996. Praha: Učitelské noviny, Gnosis, 1997.)

Zajímavou knihou z konce první dekády našeho století je studie o občanském vzdělávání dospělých, která je (slovy jejích autorů) první prací, která usiluje o komplexní zmapování občanského vzdělávání dospělých v České republice. Její autoři o tom (s. 6) píši: „Základní problém, který se při analýze projevil, je absence dlouhodobé koncepce občanského vzdělávání. V současné době není jasné, co považujeme za občanské vzdělávání a co nikoli, nepanuje shoda na jednotné podobě a nejsou $\mathrm{k}$ dispozici vhodné prostředky pro další rozvoj. Jednotlivé evropské státy zpravidla mají velmi odlišné modely občanského vzdělávání, které respektují kulturní odlišnosti a vycházejí z národních tradic. Občanské vzdělávání není možné zavést pouhým implementováním vnější koncepce. Je potřeba navázat na společenskou situaci a dojít k široké shodě ohledně vhodného přístupu. Česká republika má bohatou historii v oblasti občanského vzdělávání, která však v současné době není př́liš reflektována." (Analýza občanského vzdělávání dospělých, 2010.)

${ }^{26}$ Pojem „,funkční gramotnost“, který začal být v české literatuře používán po r. 1999, nelze směšovat s pojmem „finanční gramotnost“. Funkční gramotností se rozumí uplatnění dosažené úrovně vzdělanosti v praxi (Simonová, 2010; Glabazn̆a, 2016). 
společnosti a aktivně vystupoval na trhu finančních produktů a služeb. Finančně gramotný občan se orientuje $\mathrm{v}$ problematice peněz a cen a je schopen odpovědně spravovat osobní/rodinný rozpočet, včetně správy finančních aktiv a finančních závazků s ohledem na měnící se životní situace.“ (Národní strategie finančního vzdělávání, 2010.) 27

\subsubsection{OECD o úrovni gramotnosti}

$\mathrm{Z}$ mezinárodních organizací se měřením úrovně vzdělání (gramotnosti) ve světě dlouhodobě zabývala OECD. Věnovala značnou pozornost zejména statistickému sledování a srovnávání míry finanční gramotnosti. Za účelem sběru statistických údajů pomocí statistických šetření a jejich mezinárodní srovnatelnosti postupně propracovávala závazné metodologické postupy. OECD např. pro členské země vytvořila soustavu indikátorů, které vládám členských zemí usnadňují vypracovávat potřebné údaje. Tyto indikátory (celkem 27) jsou rozčleněny do čtyř skupin (A až D), jsou ohodnocovány určitým počtem bodů a podle počtu bodů je sestavováno pořadí zemí. (OECD Indicators. 2018.)

Informace o metodologickém postupu jsou uveřejňovány $\mathrm{v}$ příručce pro mezinárodní srovnávací statistiku úrovně vzdělání. (OECD Handbook.) OECD propracovala také klasifikaci různých druhů a forem vzdělání (viz níže schéma druhů gramotnosti v Bloku 6).

OECD (25. 9. 2001) definovalo statistiku o vzdělání jako „...organised and sustained communication designed to bring about learning“. $Z$ této charakteristiky vycházela $\mathrm{v}$ r. 2010 výše citovaná česká Národní strategie.

Blok 6

Schéma druhů gramotnosti

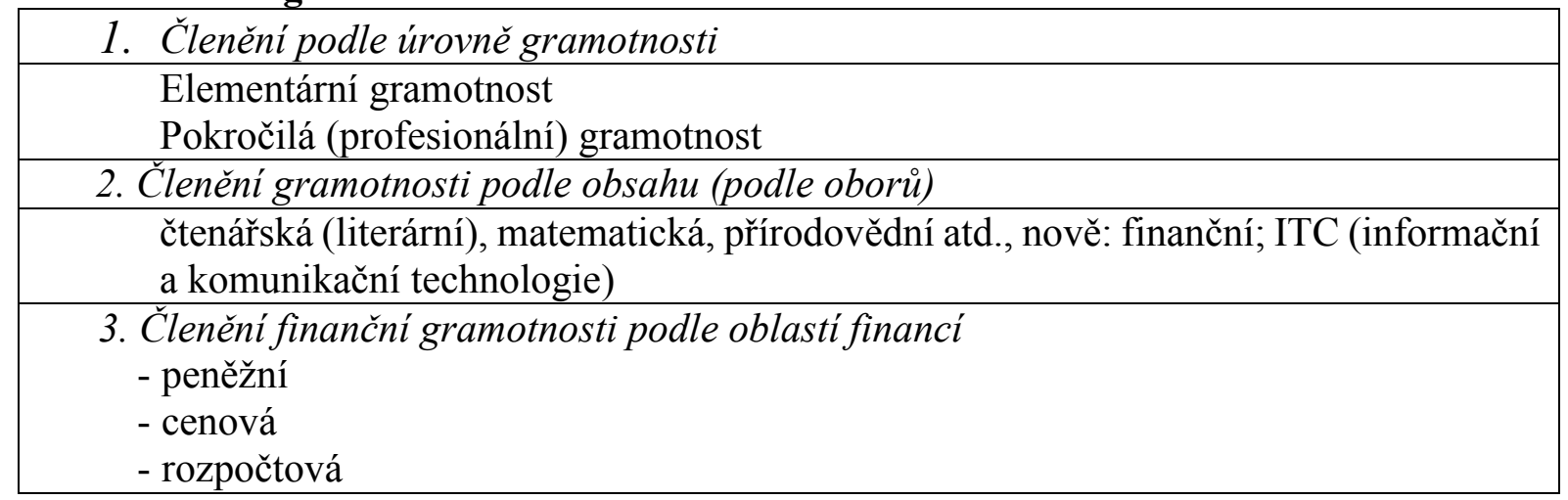

Pramen: vlastní sestavení (V. P.) s využitím zahraničních pramenů. V literatuře existuje řada odlišných klasifikací druhů gramotnosti.

V zahraniční literatuře bývá rozlišována „formal literacy“ od „informal literacy“, což při překladu do češtiny působí určité potíže; v češtině totiž v obou př́ípadech doslovný překlad zní „,neformální gramotnost“. V praxi (vzhledem k rozdílnému obsahu obou pojmů) v zavedené terminologii se slovo „,informal“ prostě „počeštilo“ na „informální“, jako v mnoha jiných př́ípadech, třeba když „,blog““ (anglicky) v češtině prostě také je „,blog“. 28

\footnotetext{
${ }^{27}$ Národní strategie finanční vzdělanosti byla publikována jako právní dokument: UV338_2010_NSFV.pdf.

${ }^{28} \mathrm{~V}$ českých pracích byla snaha přesněji odlišit oba pojmy. „Celoživotní učení jako nepřetržitý proces v průběhu celého života se odehrává v různých situacích. Můžeme je rozčlenit: Formální vzdělávání je realizováno ve školách či v jiných vzdělávacích institucích. Je strukturováno (vzdělávací cíle, učební čas, učební podpora ze strany
} 
Vzdělávání dospělých - jako jeden z druhů vzdělávání - v druhé polovině 90 . let různí autoři definovali odlišně. Z. Palán např. uvedl tuto definici: „,...Vzdělávání dospělých je obecný pojem pro vzdělávání dospělé populace a zahrnuje veškeré vzdělávací aktivity realizované jako řádné školské vzdělávání dospělých (získání stupně vzdělání) nebo jako další vzdělávání a vzdělávání seniorů.“ (Palán, 1997. Citace uvedena podle pozdějšího vydání této publikace z r. 2002, s. 237.)

Pokusy o typologii vzdělávání dospělých se datují spíše až doby přesahující časový horizont této práce. Do let 1997-1998 spadá např. snaha vymezit obsah a druhy/formy vzdělávání dospělých na základě rozlišení tří hlavních částí vzdělávání dospělých, a to na: 1. Vzdělávání dospělých, vedoucí k dosažení stupně vzdělání; 2. Jako tzv. druhou šanci pro ty, kdo se z jakýchkoliv důvodů ve školách nevzdělávali dř́ve; 3. Ostatní součásti vzdělávání dospělých. (Viz Bílá kniha, vyd. z r. 2001. ISBN 80-211-0372-8.) ${ }^{29}$ Tyto snahy úzce souvisely s nutností vypořádat se s nedostatky, které v oblasti školské politiky České republice OECD vytýkalo v rámci svého výzkumu školských soustav a školské politiky v Evropě. ${ }^{30}$

V dalším výkladu se zabýváme především vývojem finančního vzdělávání (včetně zkoumání jeho úrovně), tedy nikoliv vzděláváním dospělých jako celku. (Národní strategie finančního vzdělávání 2010, MŠMT ČR.)

\subsection{2 Účast ČR na výzkumu gramotnosti v rámci OECD}

V letech 1994-1998 OECD realizovala první rozsáhlý mezinárodní výzkum o gramotnosti dospělých (International Adult Literacy Survey -IALS). Na tento výzkum navázal další, inovovaný propracovanější výzkum gramotnosti dospělých.

Česká republika se zapojila - jako člen OECD - do druhého mezinárodního výzkumu gramotnosti dospělých. (Second International Adult Literacy Survey, 1997.) I když se výzkum se nezabýval prioritně finanční gramotností, zapojení do něho mělo pro ČR - jako pro nového člena OECD - značný význam. ${ }^{31}$

učitele). Vede k získání certifikátu a je záměrné (z pohledu učícího se jedince). Neformální vzdělávání je poskytováno různými typy organizací (soukromé vzdělávací instituce, nevládní neziskové organizace, zařízení zaměstnavatelů, školská zařízení a další). Je strukturované (vzdělávací cíle, učební čas, podpora), ale zpravidla nevede k žádnému certifikátu. Z pohledu učícího jedince je záměrné. Př́ikladem mohou být volnočasové aktivity, jazykové a počítačové kurzy, krátkodobá školení a přednášky či rekvalifikační kurzy.“ (Ministerstvo školství, mládeže a tělovýchovy - Národní program rozvoje vzdělávání v České republice. Bílá kniha. Vydal: Ústav pro informace ve vzdělávání v nakladatelství Tauris, 2001, s. 7.) Pro současný výklad termínu „informal“ viz Matthews, 2018.

${ }^{29}$ Do uvedené třetí skupiny autoři Bílé knihy řadili např. zájmové vzdělávání, občanské vzdělávání, vzdělávání seniorů apod.

${ }^{30}$ OECD si od vlády ČR vyžádalo pro toto hodnocení množství podkladů. O kvalitě těchto šetření ex post vznikla diskuse, kdy - na rozdíl skupiny autorů podkladů, kteří tyto podklady považovali za dostatečné, L. Čerych jako jediný vystoupil s opačným názorem.. Názorové diskuse mezi odborníky se vlekly velmi dlouho a nevedly prakticky k žádným významným pokrokům v nápravě zjištěných nedostatků. Teprve vstup ČR do Evropské unie v r. 2004 vyvolal potřebu, aby konečně - po letech váhání - byla vypracována první koncepce národního vzdělávání. Byla uveřejněna až r. 2010. (Národní strategie vzdělávání 2010, MŠMT ČR.) Vznik této koncepce měl značný vliv na orientaci výzkumu otázek dalšího rozvoje vzdělávání v ČR a v jeho rámci také na orientaci vzdělávání dospělých (včetně finančního vzdělávání).

${ }^{31}$ OECD tehdy bylo jedinou mezinárodní organizací, v níž bylo České republice přiznáno postavení ekonomicky vyspělé země. 
Pro období 90 . let je typické, že v oblasti vzdělávání stály v popředí otázky přeměny základního a středoškolského vzdělávání, nikoli systémová transformace českého vzdělávacího systému jako celku na základě určité promyšlené a vědecky odůvodněné koncepce.

Svědčí o tom např. skutečnost, že česká odborná veřejnost nebyla podrobněji seznámena $\mathrm{s}$ účastí ČR na výzkumu gramotnosti dospělých hned na počátku, ale až mnohem později (Simonová, 2010). Po uveřejnění výsledku druhého výzkumu OECD v zahraničí byly v ČR okolo r. 2007 zahájeny práce na české Národní strategii.

\section{Shrnutí}

K zaostávání gramotnosti dospělých (včetně finanční gramotnosti) došlo v důsledku souběhu řady událostí, mimo jiné proto, že hlavní pozornost MŠMT se soustředila na zabezpečování naléhavých změn ve školské soustavě. Ani 3 výzkumné ústavy, které tehdy v resortu MŠMT působily, se otázkám mimoškolního vzdělání dospělých prioritně nevěnovaly. Značnou úlohu hrála i skutečnost, že MŠMT svou úlohu v řizení českého školství plnila v užším rozsahu, než by bylo bývalo potřebné. Kompetence ústředních úruadů $\mathrm{V}$ té době totiž nebyly dostatečně přesně vymezeny, takže docházelo $\mathrm{k}$ překrývání nebo nedokrývání některých činností, anebo vůbec nebyly pokryty (Analýza OVD, 2010). Tím si lze vysvětlit i to, že ČNB, ministerstvo financí, nově založená Burza cenných papírů i soukromé vzdělávací instituce (zejména v letech 19931997) se chopily iniciativy $\mathrm{v}$ oblasti mimoškolního finančního vzdělávání v situaci, kdy úroveň finančního vzdělání byla velmi nízká, ne-li - v porovnání se zahraničím - zpočátku téměř nulová (OECD, 2006). 


\section{Aplikace zahraničních poznatků v oblasti finančního vzdělávání v České republice}

Účelem této kapitoly je charakterizovat a zhodnotit činnost různých zahraničních firem, které již záhy po listopadu začaly nabízet v Československu a později v České republice různá školení o finančních otázkách, zejména o cenných papírech, o obchodování na burzách cenných papírů apod.

Kapitola je rozčleněna na dvě subkapitoly. První z nich (4.1) rozebírá klady a zápory nabídek školení o finančních otázkách, které předkládaly různé zahraniční firmy. Druhá subkapitola (4.2) zkoumá překážky, které po roce 1990 bránily efektivnímu využití zahraničních nabídek finančního vzdělávání, předložené nejčastěji v rámci zahraniční pomoci.

\subsection{Nabídky zahraničních firem provádět školení o finančních otázkách}

Po roce 1989 se několik zahraničních vzdělávacích institucí pokusilo nabízet své služby v bývalém Československu, resp. později od r. 1993 v České republice. V první etapě sledovaného vývoje (1990-1992) vesměs šlo o evropské firmy (z Velké Británie, Švédska a Rakouska) a jen výjimečně o firmy z USA a Kanady. Tyto společnosti nabízely ze svého portfolia různé vzdělávací kurzy, které však z větší části nepočítaly s nízkou úrovní finanční gramotnosti potenciálních účastníků (Pavlát, O vzniku Burzy cenných papírů, 2009).

Jedním z markantních případů nekompetentního a necitlivého přístupu byla akce švédské společnosti OM. Tato firma uspořádala v Praze bezplatný jednodenní seminář, kterému předcházela bombastická reklama, $\mathrm{v}$ té době zcela neobvyklá.

Firma OM na semináři mj. přišla s vlastními návrhy na organizaci českého kapitálového trhu. Tyto návrhy však neodpovídaly tehdejší finanční infrastruktuře ČSFR, která byla teprve na samém počátku svého vzniku. Neodpovídaly ani lokálním technickým možnostem, nehledě k již zmíněné nedostatečné finanční gramotnosti potenciálních účastníků. Seminář se konal v angličtině. Mnozí účastníci nerozuměli ani slovo, takže seminář fakticky skončil úplným debaklem. Později se ukázalo, že tehdy silně expandující společnost OM (specializovaná na obchodování s finančními deriváty) měla eminentní zájem podílet se na očekávaném zavádění opčních obchodů na vznikajícím českém kapitálovém trhu.

Tento případ nebyl ojedinělý. Společným rysem těchto pokusů bylo nabízet různá školení s obsahem, který ignoroval skutečné potřeby finančního vzdělávání v ČSFR - v zemi, v níž 40 let neexistovaly běžné finanční instituce tržní ekonomiky. Tento přístup nerespektoval základní pedagogické zásady, mj. metodu postupovat od jednodušších otázek ke složitějším apod.

Také v průběhu druhého základního období vývoje českého kapitálového trhu (1993-1994) docházelo $\mathrm{k}$ šíření různých neúplných nebo zkreslených informací týkajících se investování do cenných papírů. Mnohé z informací o obchodování cennými papíry, které se do ČR dostaly ze západních zemí, byly zavádějící nebo dokonce zcela nepravdivé. Někteří čeští re-emigranti se projevili jako „falešní proroci“, když vyprávěli smyšlené bajky o tom, jak zbohatnout na kapitálovém trhu. Někdy bylo obtížné proti podobným příběhům vystoupit př́mo, protože tyto 
pověsti kolovaly pouze mezi důvěřivými lidmi, kteří o cenných papírech nic nevěděli. Podvodníci je často připravili o peníze, které vybírali jako zálohu na slibované tzv. výhodné zhodnocení.

Těmto excesům bylo možno čelit jen postupným finančním vzděláváním dospělých, které co do obsahu i formy odpovídalo všeobecně nízké úrovni znalostí této skupiny obyvatelstva. Bylo nutno soustředit pozornost na to, aby se co nejvíce lidí mohlo seznámit alespoň se základními pojmy. Pokud šlo o širokou veřejnost, v tomto úsilí hrál hlavní roli denní tisk (viz dále kap. 8).

\section{Exkurz 1}

\section{Finanční vzdělávání v zahraničí v první polovině 90 . let}

1. Charakteristika vzdělávání finančních specialistů pro oblasti kapitálového trhu v USA, Německu, Francii a Velké Británii (viz literatura).

2. Vzorový přiklad konstrukce kurikula vzdělávání v oblasti cenných papírů:

Kanadská publikace: The Canadian Securities Course. 1990. ISSN 0317-9451. 399 stran. Kurz obsahuje Předmluvu, 21 kapitol a rozsáhlou bibliografii.

V Předmluvě kurzu jsou uvedeny základní informace o Canadian Securities Institute (CSI), o jeho cílech a činnosti; přehled výukového kurzu, jeho účel a obsah; návod, jak kurz studovat; přehled kanadského finančního tisku; informace o jiných vzdělávacích kurzech CSI. Dále je zařazen (jako samostatná část) slovník odborných finančních termínů včetně názvů citovaných institucí.

Kap. 1 Introduction to Canadian Investment Finance uvádí přehled o investování v Kanadě, stručnou historii investování do cenných papírů a o jeho očekávané budoucnosti.

Kap. 2 Suppliers and Users of Investment Capital (X)

Kap. 3 The Canadian Securities Industry

Kap. 4 Basic of Incorporation

Kap. 5 Understanding of Financial Statements

Kap. 6 Interpreting Financial Statements

Kap. 7 Government Bonds and Debentures (X)

Kap. 8 Corporate Bonds and Debentures (X)

Kap. 9 Secondary Bond Market: Bond Yield Calculation and Price Movements

Kap. 10 Judging the Investment Quality of Corporate Bonds and Debentures

Kap. 11 Preferred Shares

Kap. 12 Common Shares (X)

Kap. 13 Factors Affecting Securities Prices (X)

Kap. 14 Investment Dealers Association of Canada

Kap. 15 The Stock Exchanges in Canada

Kap. 16 Buying and Selling Equities (X)

Kap. 17 How Canadian Tax Laws Affect Investors

Kap. 18 Canadian Mining and Oil Securities

Kap. 19 Special Types of Securities

Kap. 20 Building and Managing Investment Portfolio

Kap. 21 Regulation and Investment protection(X)

Bibliography

Výše uvedená kanadská publikace z r. 1990 byla již třetím vydáním stejnojmenné publikace (1. vyd. r. 1964, 2. v roce 1970). Kurz CSI představuje komplexní kurikulum o „kanadském průmyslu cenných papírů“. Pro IPRFT sloužilo jako jeden z cenných (bohužel tehdy nedostižných) inspiračních vzorů pro zpracovávání českých učebních pomůcek. Využito 
však mohlo být v českých podmínkách začínajícího kapitálového trhu jen 7 kapitol, výše označených jako $(\mathrm{X})$.

Pramen: The Canadian Securities Course (1990). ISSN 0317-9451.

\subsection{Př́ekážky efektivního využití zahraniční pomoci v oblasti finančního vzdělávání}

Aplikace zahraničních finančních poznatků a zkušeností do praxe v jiné zemi (proces zde označovaný jako „learning transfer“) a efektivní využívání získaných poznatků a zkušeností má svá rizika.

Úspěšnost transferu obvykle naráží na četné, často i předem netušené překážky. Lze je shrnout do několika skupin, které jsou zde stručně popsány: 1. omezené finanční možnosti nově založených českých edukačních fïrem, nutných pro přípravu mimoškolního finančního vzdělávání dospělých, spolu s nedostatkem lektorů i moderního technického vybavení výuky; 2. vzhledem k omezeným jazykovým znalostem zájemců o finanční vzdělávání se téměř všechny kurzy konaly v češtině a také učební pomůcky musely být k dispozici v češtině; 3. odlišnost struktury relevantních finančních institucí; 4. odlišnost kulturního prostředí; 5. náboženské zvyklosti; 6 . etnické problémy; 7. rozdílná výchozí úroveň základní gramotnosti; 8. rozdílná výchozí úroveň finanční gramotnosti; 9. nedostatečná vybavenost technickými prostředky nutnými k transferu poznatků; 10. podmínka disciplinovaného chování účastníků transferu a vysoká úroveň jejich motivace.

Tento seznam není dokonalý ani úplný a jistě by bylo možné jej obohatit o další položky, avšak zde jde hlavně o to, vysvětlit výše uvedené překážky transferu z vyspělých evropských kapitalistických zemí do České republiky v podmínkách 90. let, tj. krátce po přechodu politické moci do rukou stoupenců demokratického zř́zení.

Vlády řady vyspělých evropských zemí jako např. Velká Británie, Francie, Belgie, Nizozemí aj. se rozhodly věnovat určité finanční prostředky na pomoc transformačnímu procesu v bývalých socialistických zemích, většinou v podobě typu britského Know-How fondu. Mechanismus tohoto fondu umožňoval západním podnikatelům, aby z prostředků fondů realizovali v ČSFR a od r. 1993 v ČR různé akce v oblasti poradenské a edukační činnosti přispívající ke vzniku kapitálového trhu, resp. celého finančního sektoru.

Většina konkrétních akcí tohoto druhu byla již dostatečně popsána v literatuře, a proto je zde věnována pozornost konkrétním překážkám a rizikům z výše uvedeného seznamu.

Ad 1. Přechod od tzv. plánovaného hospodářství k tržní ekonomice vytvářel poptávku po kvalifikovaných pracovnících $\mathrm{v}$ nových profesích $\mathrm{v}$ institucích finanční sféry včetně existujících a nově zakládaných bank, v podnicích i v některých útvarech státní správy. Lze říci, že zájem o finanční poznatky byl na počátku 90. let u většiny dospělých obyvatel mimořádně vysoký, a to i v prŕpadech, kdy $\mathrm{k}$ tomu nebyli existenčně př́mo nuceni.

Hned od počátku bylo zřejmé, že přímý transfer finančních poznatků pro dospělé obyvatelstvo zahraniční poradenské a edukační firmy nebudou schopny v dostatečné míře zajistit, a že hlavní tíhu transferu - dříve nebo později - ponesou sami Češi z řady objektivních důvodů. Většinu 
těchto firem představovaly malé společnosti s r. o. a jednotlivci, podnikající na základě živnostenského oprávnění.

Ad 2. Jazykové znalosti průměrného českého dospělého občana nebyly vyhovující. Jedním ze základních předpokladů finančního vzdělávání bylo zabezpečení této výuky včetně učebních pomůcek v češtině; spolu s tím vznikala i nutnost vytvářet odpovídající finanční terminologii.

Ad 3. Značnou překážkou transferu bylo to, že ve vyspělých evropských zemích existovala rozvinutá sít' finančních institucí včetně jejich infrastruktury, kdežto v ČR vhodná sít' (s výjimkou bank) teprve vznikala. Přri transferu poznatků o institucionální infrastruktuře kapitálových a finančních trhů bylo nutno aplikovat takový způsob výkladu funkcí finančních institucí, který by český posluchač byl schopen pochopit. Je zřejmé, že základní transfer poznatků o finanční sféře musel probíhat na základní úrovni (basic) nebo středně složitém výkladu (inter-mediate).

Ad 4. Odlišnost kulturního prostředí v př́ípadě ČR nehrála (po oddělení Slovenska) významnější úlohu.

Ad 5-7. Totéž platí i pro některé další položky z výše uvedeného seznamu, zejména pro otázku náboženského vyznání (bod 5), pro otázky etnické (bod 6) a pro otázku základní gramotnosti (bod 7) vzhledem k tomu, že v ČR byla dávno zavedena povinná školní docházka, číst a psát uměl každý dospělý - negramotnost byla výjimkou.

Ad 8. Odlišná situace byla v otázce úrovně finanční gramotnosti. Tehdy byla tato úroveň hluboce pod evropskou úrovní.

Ad 9. V technické vybavenosti české školství rovněž nevynikalo; základní vyučovací pomůckou - i v mimoškolní výuce dospělých - stále zůstávala tabule a kř́ída. Výjimkou bylo vybavení tzv. zpětným projektorem a magnetofonem.

Ad 10. Vzhledem k vysoké motivaci účastníků vyučovacích kurzů pro dospělé existovala vysoká disciplinovanost většiny účastníků pořádaných kurzů, zejména takových kurzů, na základě nichž úspěšní účastníci získávali kvalifikační osvědčení (např. tzv. makléřské kurzy).

I když byly podmínky pro organizování mimoškolního finančního vzdělávání v ČR celkově méně prŕiznivé než ve většině západoevropských zemí s rozvinutými finančními trhy a finančními soustavami, je prokazatelnou skutečností, že i přes deklarování nezbytnosti finančního vzdělávání český stát na počátku 90. let připustil jeho chaotický vývoj a nevěnoval jeho řízení ani dostatek potřebné péče, ani dostatek finančních prostředků. Jednou z příčin byla převaha liberalistického pojetí soukromého podnikání a nedostatek politické vůle k zabezpečení optimálního využití zahraničních poznatků v rozvoji českého kapitálového trhu. 


\section{Shrnutí}

Počátky mimoškolního finančního vzdělávání dospělých byly $\mathrm{v}$ období před rozdělením Československa na dva samostatné státy nedostatečně uspořádané a evidované.

S výjimkou SBČS se ani tehdejší federální ministerstvo školství, tělesné výchovy a sportu, ani federální ministerstvo financí otázkami finančního vzdělávání v potřebné míře nevěnovaly. $\mathrm{Na}$ počátku r. 1992 před očekávaným rozdělením Československa učinilo federální ministerstvo financí ČSFR některé kroky, které usnadnily Ministerstvu financí ČR zabývat se přípravou opatření k zabezpečení finančního vzdělávání pracovníků v oblasti postupně vznikajících institucí finanční sféry.

Teprve koncem r. 1992 se zejména v rámci příprav na založení pražské Burzy cenných papírů začalo počítat s organizovaným vzděláváním budoucích odborníků finanční sféry.

Řada nabídek zahraničních poradenských a vzdělávacích firem musela být odmítnuta, protože negarantovaly efektivní využití transferovaných finančních poznatků. ČNB, MFČR i Př́pravný výbor pro založení pražské Burzy cenných papírů na základě expertních posudků a doporučení (viz kap. 8) pečlivě vážily nabídky různých přednáškových kurzů. Nakonec se dospělo k názoru, že efektivnímu využití podobných kurzů brání přinejmenším 3 druhy překážek: (a) nedostatečné jazykové znalosti potenciálních účastníků nabízených kurzů, (b) nerozvinutost české finanční sféry, v níž by se účastníci kurzů seznamovali s finančními produkty, s procedurami a institucemi, z nichž mnohé na vznikajícím českém kapitálovém trhu tehdy ještě neexistovaly a fakticky ani existovat nemohly, (c) finanční, technické a personální překážky bránící transferu potenciálu finančního vzdělávání dospělých.

Hlavní faktory ovlivňující možnosti transferu potenciálu finančního vzdělávání dospělých osob v ČR:

1. Zájem o finanční vzdělávání a profesní motivace.

2. Jazykové a terminologické bariéry.

3. Technické, finanční a personální překážky.

4. Heterogenní vstupní úroveň frekventantů studijních kurzů.

Zároveň se však dospělo k poznání, že transfer finančních poznatků může být efektivní v oblasti poradenské a expertní činnosti. Tento přístup se osvědčil zejména $\mathrm{v}$ př́ípadě přijetí zahraniční pomoci Pařížské burzy při budování BCPP a rovněž v případě poradenských služeb britské společnosti Coopers and Lybrand, Ltd. 


\section{5 Úloha Ministerstva financí ČR v oblasti podpory finančního vzdělávání}

Účelem této kapitoly je stručně popsat a zhodnotit úlohu ministerstva financí $\mathrm{v}$ oblasti finančního vzdělávání v jednotlivých etapách sledovaného období (viz kap. 1, subkap. 1.2), která prošla zásadními změnami. Zatímco v letech 1990-1992 byla otázka finančního vzdělání pro resort financí v podstatě okrajovou záležitostí ve srovnání se zájmem SBČS, v jejíž struktuře tehdy fungoval Bankovní institut, v letech 1993-1994 úloha MFČR v souvislosti se založením BCPP, a.s., v Praze a se zahájením obchodování cennými papíry (souběžně s tzv. RM-S) posílila. Ve třetí etapě vývoje finanční soustavy ČR a jejího finančního trhu (19951997) již MFČR výrazněji zasahovalo i do otázek mimoškolního finančního vzdělávání pracovníků finančních institucí a organizaci, která spadala do dozorové činnosti odboru dozoru MFČR (Pavlát - Kubíček, 2010). V tomto období se vytvářely základy pro dílčí reformy $\mathrm{v}$ oblasti obchodování cennými papíry včetně vzniku Komise pro cenné papíry.

Kapitola 5 obsahuje 4 subkapitoly. První z nich (5.1) pojednává o vývoji dozorové činnosti MFČR během sledovaného období. Druhá subkapitola (5.2) charakterizuje a hodnotí regulaci a dozor nad kapitálovým trhem v letech 1993-1994. Třetí subkapitola (5.3) popisuje činnost ministerstva financí v oblasti péče o odborné školení makléřù. Čtvrtá subkapitola (5.4) se zabývá činností MFČR v období přípravy reforem v regulaci a dozoru (1995-1997).

\subsection{Dozorová činnost MFČR (1990-1992)}

MFČR zř́dilo na základě usnesení Finanční rady v únoru 1992 „Komisi pro koordinaci rozvoje kapitálového trhu“. Členy této komise jmenoval federální ministr financí Václav Klaus. V souvislosti s nutností zabezpečení dozoru nad kapitálovým trhem byly ve struktuře MFČR provedeny organizační změny a do této struktury byl začleněn nový odbor. Do té doby nebyl žádný pracovník ministerstva pověřen dozorem nad kapitálovým trhem (!). Dozorovou činnost nad BCPP, a.s., měl zabezpečovat burzovní komisař, lokalizovaný př́mo na burze.

Odbor státního dozoru nad kapitálovým trhem byl ve struktuře MFČR zřízen k 1. záríi 1992. V odboru existovala 2 oddělení: (1) oddělení dozoru a (2) oddělení organizátorů trhů, obchodníků a makléřů. Odbor měl k datu zahájení své činnosti 31 pracovníků. Odbor státního dozoru byl zřízen v pravý čas, nebot' 1. ledna 1993 zřízené Středisko cenných papírů fungovalo ve zkušebním provozu od dubna; od 6. dubna 1993 zahájila obchodování Burza cenných papírů, a.s., a také RM-S.

Mezi prioritní úkoly oddělení dozoru patřilo zabezpečení dostatečného počtu makléřu pro výkon odborných obchodních činností obchodníků s cennými papíry. Tento úkol měl být splněn k 1. lednu 1994.

V jednotlivých etapách sledovaného období prošla dozorová činnost v resortu ministerstev financí výraznými změnami. Bylo již konstatováno, že v letech 1990-1992 dozorová činnost v resortu financí ve srovnání s následujícím obdobím let 1993-1994 byla v rostoucí míře omezována co do obsahu i rozsahu rámcem tehdy existujících právních předpisů týkajících se kapitálového trhu, jejichž nedostatky se negativně projevovaly v praxi obchodování cennými papíry. 


\section{Problémy nové české legislativy po r. 1990}

Základní nedostatek tehdy zvolené metody postupné tvorby legislativy pro zahájení přechodu $\mathrm{k}$ tržní ekonomice (,per partes“) spočíval $\mathrm{v}$ nedostatečné provázanosti jednotlivých zákonů a na ně navazujících dalších právních předpisů. Tento nedostatek vyvolal potřebu častých novelizací zákonů, z nichž některé již při svém prvním vyhlášení neodpovídaly tehdejším evropským standardům. Týká se to např. zákona o cenných papírech nebo zákona o burzách cenných papírů. I když legislativní otázky nejsou předmětem této knihy, je nezbytné alespoň stručně poukázat na zvláštnost podmínek a okolností, za nichž nové transformační zákony vznikaly. Tyto anomálie se pochopitelně promítaly do dalšího vývoje českého kapitálového trhu a musely být postupně - bohužel často se značným zpožděním - odstraňovány.

O nedostatcích v právní úpravě kapitálového trhu v ČR je blíže pojednáno v práci Pavlát, V. O vzniku Burzy cenných papírů Praha, a.s., 2008 (dosud nepublikovaný rukopis; zejména kap. 6,8 a 14).

Tíha dozoru na český kapitálový trh od počátku spočívala na MFČR jako republikovém orgánu České republiky. Není od věci poznamenat, že v prvním období po r. 1989 (1990-1992) bylo zásluhou vedení tohoto ministerstva to, že dokázalo využít řady externích odborných expertíz $\mathrm{k}$ tomu, aby kvalifikovaně zamezilo pokusům některých zahraničních firem nebo podnikavců v přeskočení nezbytných fází ve vývoji vznikajícího českého kapitálového trhu. Jako jeden z markantních př́kladů, o nichž je zmínka i na jiných místech této publikace, je pokus firmy OM získat zakázku k zahájení obchodování finančními deriváty, což bylo v té době nejen předčasné, ale - při neexistenci burzy cenných papírů - i velmi riskantní (IPRFT - Memorandum, 1993). Bohužel $v$ některých jiných př́ípadech (mj. v otázce vzniku fondů kolektivního investování) ministerstvo podlehlo vnějším tlakům. V tomto prvním období zůstávaly otázky kolektivního investování v resortu financí téměř zcela stranou. Na tomto místě nutno uvést, že za otázky školství komplexně odpovídalo Ministerstvo školství, jehož prioritou byla péče o rozvoj školního vzdělání v transformačním období. Škodlivost resortismu je obecně známá, avšak v praxi houževnatě dodnes přetrvává (viz též kap. 8).

\subsection{Regulace a dozor nad kapitálovým trhem v letech 1993-1994}

V této druhé etapě vývoje českého kapitálového trhu se podařilo dosáhnout řady významných úspěchů. Především začala obchodovat BCPP (a paralelně také RM-S), činnost zahájilo Středisko cenných papírů a na MFČR začal fungovat státní dozor nad kapitálovým trhem.

Zároveň se již rýsovaly některé reálné problémy. Tak např. jednotlivé články institucionální struktury začínajícího českého kapitálového trhu se rozvíjely nerovnoměrně. Opožd'oval se např. vývoj v pojišt'ovnictví, ale naopak počet obchodníků s cennými papíry nabobtnal a také bank bylo př́liš mnoho na sotva započavší kapitálový trh.

Nadále chyběla centrální instituce $\mathrm{v}$ podobě Komise pro cenné papíry, která by byla schopna komplexně zvládnout problémy rozvoje kapitálového trhu. Tento problém byl do určité míry tabuizován: o této otázce po dlouhou dobu nebylo považováno za vhodné volně diskutovat. Až dosud nikde nebylo plně prokázáno, proč rozhodující vládní místa - a část politické scény zůstávala inertní vůči tomuto základnímu požadavku, platnému i pro začínající kapitálové trhy 
(emerging capital markets). Skutečné důvody (nikoliv zástupné důvody uváděné obvykle v diskusích zastánců regulace s liberálními odpůrci regulace) nikdy nebyly uspokojivě vysvětleny a pravděpodobně ani nebudou moci být vysvětleny pro nedostatek důkazů (viz dále Pavlát Kubíček, 2010).

Také technická infrastruktura českého kapitálového trhu zaostávala za evropským standardem i za existujícími potřebami rostoucího trhu. Značné nedostatky rovněž existovaly v informační oblasti: množství, kvalita a tok informací neodpovídaly potřebám trhu. Státní dozor nad mimoburzovními trhy zaostával co do kvality za dozorem nad burzovními trhy.

V tomto období se také již zřetelněji začaly projevovat nedostatky $\mathrm{v}$ právních předpisech, upravujících fungování českého kapitálového trhu. Projevily se např. i ve sporu mezi MFČR a ČNB o dozor nad investičními společnostmi a investičními fondy.

Kromě toho MFČR zpřísnilo dozor nad BCPP, kde z podnětu burzovního komisaře (zástupce zájmů státu) $\mathrm{v}$ řadě př́padů burze vracelo návrhy burzovních předpisů $\mathrm{k}$ dopracování nebo přepracování. Určitá diskuse mezi ministerstvem a burzou vznikla i v souvislosti s uzavřením smlouvy o pomoci Pařižské burzy při zprovozňování BCPP.

Za velmi záslužná nutno považovat i zamítavá stanoviska ministerstva $\mathrm{v}$ případě návrhů na povolení vzniku tzv. Opční burzy (za kterou se skrýval tzv. H-systém). (Pavlát, O vzniku Burzy cenných papírů Praha, a.s., 2008.)

Nová situace nastala již v r. 1994, kdy začala narůstat kritika různých nešvarů, které se po prvním roce otevření českého kapitálového trhu začaly objevovat. Tato kritika vycházela fakticky od všech jeho účastníků - od investorů, emitentů i zprostředkovatelů, kdy nejaktivnějšími kritiky byli hlavně obchodníci s cennými papíry. Nespokojena byla i sama BCPP; nešlo prritom pouze o absenci Komise pro cenné papíry nebo o vytvoření centrálního vypořádání cenných papírů, ale i o praxi tzv. převodů v SCP, kdy burzovní orgány nedokázaly přsesvědčit členy burzy, aby tyto převody neprováděli.

Bylo zřejmé, že MFČR již nebude moci dále ignorovat tyto signály a zachovávat faktickou nerovnoprávnost BCPP s RM-S. Nelze již zpětně zjistit, co bylo signálem pro to, aby si MFČR vyžádalo odbornou pomoc od organizace British Government Know-How Fund. Tento fond zemím s transitivní ekonomikou poskytoval bezplatnou odbornou pomoc $\mathrm{v}$ různých ekonomických otázkách, hrazenou z britských prostředků.

Podle neúplných archivních dokladů byla tato žádost MFČR britskými úřady projednávána někdy během 2. čtvrtletí 1994. Vyplývá to ze skutečnosti, že tzv. první Millerovu zprávu (označenou jako prozatímní) Jonathan Miller vypracoval na základě kontraktu „CNTR 94 3104A with the Overseas Development Administration“. (Citováno podle „The Czech Capital Market. Interim Report“ z 1. ř́jina 1994.) Tuto zprávu Jonathan Miller vypracoval po první návštěvě v Praze v září 1994.

Obsah této zprávy je uveden v Př́loze. Protože se její dvě důležité části týkají BCPP (burzovní předpisy a kapitola o finančních derivátech), je podrobnější komentář k této zprávě uveden $\mathrm{v}$ kap. 4 týkající se BCPP. Zde je účelné ještě poznamenat, že tato dvakrát přepracovaná tř́dílná zpráva (v rozsahu cca 70 stran) byla v konečném znění dokončena a předložena MFČR až 30. 
června 1995. Millerova zpráva se v její prozatímní podobě dostala do rukou pouze pěti adresátům z vybraných institucí (BCPP, MFČR, CKP a RM-S). Prozatímní zprávu J. Miller vypracoval převážně na základě podkladů o české legislativě o kapitálových trzích (Millerova prozatímní zpráva) a na základě interview se 16 osobami činnými ve finanční oblasti.

Do zadání (terms of reference) expertízy J. Millera, předložené ke schválení př́islušné britské instituci (British Know-How Fund), MFČR nezařadilo požadavek týkající se analýzy systému finančního vzdělávání a jeho úrovně v ČR, ačkoliv by to bylo tehdy vhodné a nanejvýš žádoucí. $\mathrm{O}$ důvodech, proč se tak stalo, autor této publikace nezískal žádnou spolehlivou informaci. ${ }^{32}$

\subsection{Ministerstvo financí a péče o odborné školení maklérù}

Podle platných předpisů Ministerstvo financí ČR mělo ve své kompetenci péči o finanční vzdělávání makléřu (srov. vyhlášku o makléřské zkoušce). MFČR dne 26. března 1993 zřídilo zkušební komisi ministerstva financí České republiky pro provádění makléřských zkoušek. Členy této komise jmenoval místopředseda vlády ČR a ministr financí Ivan Kočárník.

V r. 1993 MFČR pověřilo organizací a prováděním makléřských zkoušek společnost „Institut pro podporu rozvoje finančního trhu, spol. s r.o.“(dále: IPRFT). Podle smlouvy, kterou MFČR $\mathrm{s}$ uvedenou společností uzavřelo, měla tato společnost připravit náplň speciálních vzdělávacích kurzů určených pro budoucí makléře činné na českém kapitálovém trhu (podrobnosti jsou uvedeny v kap. 9).

Obsah kurzů, jejich organizaci, zkušební otázky, témata závěrečných prací i výsledky zkoušek předběžně posuzovalo tehdejší oddělení pro dozor nad kapitálovým trhem MFČR; po předběžném posouzení předkládalo návrhy do jedné z obou výše uvedených komisí.

Společnost IPRFT v dohodě s MFČR stanovila pro účastníky kurzů velmi nízký poplatek, který kryl pouze nezbytné náklady na prrípravu a organizaci kurzů. Případný výnos pověřená společnost odváděla na účet MFČR; fungovala tedy v podstatě jako dnešní veřejně prospěšné společnosti. Toto řešení bylo zvoleno proto, že ve veřejném zájmu bylo motivovat co nejvíce vhodných uchazečů o získání kvalifikace $\mathrm{k}$ činnosti maklére $\mathrm{z}$ r̆ad mladých zaměstnanců institucí finančního sektoru. Vzhledem k naléhavé potřebě dostatečného počtu makléřu pro firmy obchodníků cennými papíry byla délka běžných kurzů s náročnou náplní stlačena na 14 dní s vysokým denním počtem hodin výuky.

Kurzy byly konány pouze $\mathrm{v}$ Praze. Účastníci kurzů byli přijímáni na základě přihlášky a stručného nástupního pohovoru. Při ukončení kurzů se museli podrobit závěrečné písemné zkoušce. Na základě úspěšného složení závěrečné zkoušky byl úspěšným uchazečům vydán makléřský „Diplom“, který je opravňoval k činnosti makléře. MFČR kontrolovalo, zda obchodníci s cennými papíry zaměstnávají při výkonu funkce makléře pouze kvalifikované osoby s diplomem. (Podrobnosti o kurzech IPRFT jsou uvedeny v kapitole 9 této publikace.) V Prŕloze jsou uvedeny tyto dokumenty: Vzor Osvědčení vykonání makléřské zkoušky (z r. 1993); Seznam výsledků (počty dosažených bodů) účastníků makléřské zkoušky z období 27. 5.-18. 6. 1993 v podobě, v níž byl předán Ministerstvu financí (archiv IPRFT); Návrh IPRFT Ministerstvu financí ČR (náměstkovi ministra Ing. Klakovi) na uspořádání kurzu a

\footnotetext{
${ }^{32}$ Ve výtisku konečné zprávy, který autor této knihy má k dispozici, chybí str. 59-61, pojednávající o finančních derivátech.
} 
semináře o cenných papírech pro vybrané pracovníky finančních úřadů ČR. Kurz se neuskutečnil, nebot' MF dalo přednost vlastnímu průběžnému školení pracovníků resortu. ${ }^{33}$

V letech 1993-1997 získalo makléřský diplom na základě úspěšně absolvované závěrečné zkoušky cca 4500 uchazečů. Účastníci kurzů (s výjimkou několika jednotlivců) hodnotili úroveň kurzů velmi kladně. MFČR, které průběžně dohlíželo na průběh konaných kurzů, rovněž výsledky kurzů hodnotilo vysoce pozitivně. (Srov. Archiv MFČR; Pavlát, V.; Archiv IPRFT.)

\subsection{Období př́ípravy reforem v regulaci a dozoru (1995-1997)}

Tato etapa vývoje českého kapitálového trhu je charakterizována jako období, kdy došlo k postupné novelizaci řady předpisů, které regulovaly český kapitálový trh. Antonín Kubíček k tomu uvádí: „V těchto zákonech se bohužel nepodařilo odstranit všechna negativa, nejednoznačnosti a další chyby původních legislativních norem. .... Pokusily se však reagovat na nově vzniklé skutečnosti... Konečná podoba těchto novel však byla poznamenána mnohými kompromisy, v čemž sehrál roli i tlak na rychlé časové zvládnutí celé procedury,“a a pokračuje: „Možná, že lze tyto novely hodnotit jako dobrou základnu pro dalši novelizaci.“ (Srov. cit. publikace, str. 141.) Toto hodnocení bylo napsáno až v r. 2010, takže nejde o bonmot: po vstupu České republiky do OECD 21. prosince r. 1995 byla ČR pod trvalým tlakem, aby naše předpisy týkající se kapitálového trhu, byly co nejdřive uvedeny do souladu s mezinárodními standardy. Po vstupu ČR do Evropské unie v r. 2004 tento tlak ještě zesílil, i když stále narážel na různé překážky. V polovině roku 1996 bylo v ČR v evidenci odboru státního dozoru nad kapitálovým trhem MFČR 474 nebankovních obchodníků s cennými papíry a 39 bankovních obchodníků s cennými papíry (s 1229 makléři). Dále bylo evidováno 203 investičních fondů, 156 investičních společností, 121 otevřených podílových fondů, 172 uzavřených podílových fondů, avšak již k 31. 8. téhož roku $-\mathrm{v}$ důsledku koncentračních tendencí - se 72 investičních fondů přeměnilo na holdingové společnosti. Během r. 1997 došlo ke snížení počtu investičních společností o 18. (Pavlát-Kubíček, 2. vyd. 2010, s. 145.)

Výsledkem diskusí a nutnosti změn koncepce regulace a dozoru, které na půdě MFČR probíhaly během r. 1996, bylo přejmenování odboru dozoru na Úřad pro cenné papíry. V červenci 1997 tento úřad vypracoval podrobnou analýzu českého kapitálového trhu. (Srov. Pavlát - Kubíček, 2. vyd., 2010, s. 144-145.) Tato analýza vyústila v návrzích na významné změny na českém kapitálovém trhu, např. $v$ návrhu na vytvoření jednotného zúčtovacího a vypořádacího centra. $\mathrm{V}$ konečných důsledcích tato analýza přispěla $\mathrm{k}$ založení Komise pro cenné papíry na základě usnesení Parlamentu ČR (s účinností od 1. dubna 1998).

\footnotetext{
${ }^{33} \mathrm{Z}$ hlediska dalšího vývoje kvality práce finančních úřadů se jevilo toto rozhodnutí přinejmenším jako nedomyšlené, nebot' neznalost problematiky nových agend se vznikem kapitálového trhu se promítala i do daňové oblasti. Finanční úřady většinou byly nedostatečně personálně vybaveny (nízké vzdělání pracovníků, podprůměrné platové podmínky apod.); kdyby tehdy byli alespoň vedoucí pracovníci těchto úřradů patřičně vyškoleni v otázkách kapitálového trhu (včetně otázky rizik a potenciálních podvodů), nemuselo tehdy docházet ke zbytečným excesům. Líznerova aféra tehdy byla jen epizodickou záležitostí ve srovnání s řadou běžných chybných praktik.
} 
Blok 8

Zápis z jednání poradní komise MFČR

\section{Zápis z jednání poradní komise MFĊR pro udělování povolení $\mathbf{k}$ obchodování s cennými papíry}

Místo a doba jednání: MFČR 30. 7. 1996, 9.00-11.50 hod.

Účastníci jednání: dle prezenční listiny

Program jednání:

1) Návrh metodických pokynů pro realizaci kontrolní činnosti u obchodníků s cennými papíry.

2) Návrh sdělení ve Finančním zpravodaji pro obchodníky s cennými papíry.

3) Návrh pokynu pro realizaci licenční činnosti pro nové obchodníky s cennými papíry.

4) Rámcové podmínky pro žadatele o vedení části evidence Střediska dle $§ 70$ a) zákona o cenných papírech.

5) Podmínky smluvního převedení části databáze Střediska cenných papírů do správy jiného subjektu.

Ke všem výše uvedeným bodům byl předložen písemný materiál.

Průběh jednání:

K prvnímu bodu byl předložen návrh změny metodiky prezenčních kontrol prováděných u obchodníků s cennými papíry - nebankovních subjektů a nového způsobu kontroly, tzv. evidenčního sledování činnosti obchodníků s cennými papíry, ke kterému se odd. 102 rozhodlo přistoupit vzhledem $\mathrm{k}$ značnému nárůstu počtu obchodníků s cennými papíry.

K druhému bodu byla podána informace o návrhu sdělení odboru 10 odd. 102, který byl vypracován v souladu s novelou Zákona o cenných papírech (zák. č. 152/1996 Sb.). Sdělení seznamuje jak stávající obchodníky s cennými papíry, tak nové žadatele o povolení obchodování s cennými papíry s úpravou věcných, personálních a organizačních podmínek pro výkon činnosti obchodníka s cennými papíry a makléře.

Ve třetím bodě byla poradní komise seznámena s návrhem interního pokynu MFČR $\mathrm{k}$ realizaci licenční činnosti pro nové obchodníky s cennými papíry, zejména s výkladem kritérií MF při posuzování věcných personálních a organizačních předpokladů pro výkon činnosti obchodníka s cennými papíry a makléře.

$\mathrm{K}$ čtvrtému bodu byl předložen účastníkům návrh podmínek pro žadatele při udělování povolení o vedení části evidence střediska a princip Garančního fondu osob pověřených vedením části evidence střediska. První předložený materiál specifikuje podmínky kladené na jednotlivé žadatele o pověření vedení části evidence střediska dle $\S 70$ a) zákona č. 591/1996 Sb., o cenných papírech, v platném znění. Druhý materiál osvětluje princip fungování Garančního fondu, členství, výši vkladů jednotlivých účastníků, zánik účasti v GF atd. 
V pátém bodě vystoupil ředitel SCP a informoval o koncepci utváření subregistrů. Dále sdělil, že SCP je schopno všem subjektům kapitálového trhu nabídnout lepší podmínky spojení a zkvalitnění služeb.

$\mathrm{V}$ rozpravě $\mathrm{k}$ jednotlivým bodům programu vystoupila většina př́tomných. $\mathrm{Z}$ jednání komise vyplývají následující skutečnosti.

Poradní komise vzala na vědomí navržený postup při provádění kontrolní činnosti u obchodníků s cennými papíry - nebankovních subjektů bez větších výhrad a doporučila postupovat při realizaci kontrolní činnosti prováděné u obchodníků s cennými papíry dle předložených návrhů metodických pokynů.

Zároveň doporučila, aby v případě vzniku problémů při provádění kontrolní činnosti byly tyto problémy předloženy ke konzultaci Poradní komisi a AOM.

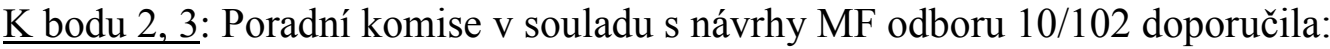

Aby výše základního jmění u obchodníků s cennými papíry činila nejméně 1 mil. Kč a byla složena (vzhledem k nutnosti zachování likvidity) v peněžní formě. U nově povolovaných obchodníků s cennými papíry je třeba složit základní jmění v uvedené výši a formě před podáním žádosti. U stávajících obchodníků s cennými papíry, kteří mají základní jmění nižší než 1 mil. Kč, je třeba navýšení základního jmění na požadovanou částku provést nejpozději do 30. 6. 1997.

- Uvádět ve výpisu z obchodního rejstř́iku pouze činnosti, které jsou v souladu se Zákonem o cenných papírech, ve znění pozdějších předpisů.

- Pro omezení možnosti vzniku konfliktu zájmů a v souladu s požadavky na čestnost provádění obchodů bude od 1. 1. 1997 makléř vykonávat aktivity prováděné z titulu svého oprávnění pouze pro jednoho obchodníka s cennými papíry (omezení se zatím netýká souběžnosti provádění výkonu makléře pro investiční společnosti a investiční fondy). Pokud obchodník s cennými papíry nebude mít zájem vykonávat činnosti dle § 36 Zákona o cenných papírech ve znění pozdějších předpisů, musí tuto skutečnost písemně oznámit odboru 10/102 MF nejpozději do 31. 12. 1996.

- MF uveřejní ve Finančním zpravodaji svůj výklad termínu „podobné činnosti“ při posuzování bezkonfliktnosti zájmů dle $§ 196$ zákona č. 513/1991 Sb., - obchodní zákoník. Za „,podobné činnosti“ bude MF považovat pracovní činnosti u investičních společností, investičních fondů, penzijních fondů, podílových fondů, bank, pojišt'oven a ratingových společností.

K bodu 4: K rámcovým podmínkám se snesla kritika z řad účastníků poukazující zejména na skutečnost, že z řad žadatelů o povolení vedení části evidence střediska jsou vyjmuty zahraniční subjekty, dále že je nereálný požadavek peněžního splacení základního jmění žadatelů. Garanční fond v takové podobě, v jaké byl prezentován, by znevýhodňoval kapitálově silnější účastníky GF, zejména pak bankovní subjekty, které by do GF přispívaly většími částkami, oproti společnostem kapitálově slabším, u kterých je větší pravděpodobnost nedodržení závazků a větší rizika vyplývající z vedení části evidence střediska. 
$\mathrm{Z}$ názorů jednotlivých účastníků komise vyplynulo, že koncepce „subregistrů“ v této podobě je pro většinu nepřijatelná, i když byla tato koncepce stavěna na v současné době platné právní úpravě zákona č. 591/1996 Sb., o cenných papírech. Lze tedy konstatovat, že připomínky se hlavně týkaly legislativních předpisů.

Diskuse otevřela řadu dalších problémů, spojených s utvářením subregistrů, které však předložený materiál nepostihl. Proto bylo rozhodnuto předložit komisi nový doplněný materiál.

K bodu 5: „Subregistry“ by měly pokrýt celou šíři problematiky kapitálového trhu, počítačový systém by měl být kompatibilní s řídicím systémem SCP.

„Subregistr“ musí fungovat ve stálém propojení se SCP za podmínek dohodnutých se SCP, aby byla zabezpečena stabilita provozního systému a možnost zásahu SCP do evidence „subregistru“ v naléhavých př́ípadech (např. přechod cenného papíru, blokace a odblokování majetkového účtu na žádost orgánů státní správy).

V Praze dne 26. 8. 1996

\section{Shrnutí}

MFČR zřídilo na základě usnesení Finanční rady v únoru 1992 „Komisi pro koordinaci rozvoje kapitálového trhu“. Členy této komise jmenoval federální ministr financí Václav Klaus. V souvislosti s nutností zabezpečení dozoru nad kapitálovým trhem byly ve struktuře MFČR provedeny organizační změny a do této struktury byl začleněn nový odbor. Do té doby nebyl žádný pracovník ministerstva pověřen dozorem nad kapitálovým trhem (!). Dozorovou činnost nad BCPP, a.s., měl zabezpečovat burzovní komisař, lokalizovaný př́mo na burze. Toto opatření bylo při vzniku BCPP realizováno a přinášelo pozitivní výsledky.

Otázky finančního vzdělávání se však dostaly do popředí až ve druhé etapě vývoje českého kapitálového trhu (1993-1994), kdy se MFČR začalo intenzivně věnovat řešení naléhavé potřeby kvalifikovaných osob pro finanční sféru.

Podle platných předpisů Ministerstvo financí ČR mělo ve své kompetenci péči o finanční vzdělávání makléřů (srov. vyhlášku o makléřské zkoušce).

MFČR dne 26. března 1993 zřídilo zkušební komisi ministerstva financí České republiky pro provádění makléřských zkoušek. Členy této komise jmenoval místopředseda vlády ČR a ministr financí Ivan Kočárník.

V r. 1993 MFČR pověřilo organizací a prováděním makléřských zkoušek společnost „Institut pro podporu rozvoje finančního trhu, spol. s r.o.“ (IPRFT - viz podrobněji dále 9.2.1.) O kurzy společnosti IPRFT byl značný zájem nejen proto, že jejich absolventi na základě jejich absolvování měli na základě získaného diplomu přednost před jinými uchazeči o zaměstnání u obchodníků s cennými papíry nebo $\mathrm{v}$ jiných podnicích a institucích finanční sféry, ale také vzhledem $\mathrm{k}$ aktuálnosti získaných informací a vzhledem $\mathrm{k}$ aplikaci nových forem výuky (viz též kap. 3 výše).

V letech 1993-1997 získalo makléřský diplom na základě úspěšně absolvované závěrečné zkoušky cca 4500 uchazečů. 


\section{6 Úloha ČNB v oblasti podpory finančního vzdělávání}

Účelem této kapitoly je prokázat, že centrální banka se zejména v první polovině sledovaného období významným způsobem angažovala nejen v oblasti přípravy obecných podmínek rozvoje kapitálového trhu, ale že od počátku podporovala také finanční vzdělávání v bankovní sféře.

Kapitola se skládá ze 4 subkapitol. V první z nich (6.1) je stručně charakterizována iniciativní role SBČS ve věci založení Burzy cenných papírů, kterou československá centrální banka sehrála v letech 1990-1992. V druhé subkapitole (6.2) jsou uvedeny některé podrobnosti o činnosti tzv. Přípravného výboru, týkající se využití kontaktů se zahraničními institucemi k posouzení návrhů SBČS na organizaci kapitálového trhu v ČSFR a na založení Burzy cenných papírů v Praze. Třetí subkapitola (6.3) se zabývá úlohou prozatímního sekundárního trhu, který organizovala SBČS. Čtvrtá subkapitola (6.4) je věnována analýze angažovanosti ČNB v oblasti vzdělávání pracovníků finanční sféry v období po rozdělení ČSFR na dva samostatné státy (1993-1998).

\subsection{Zásadní iniciativa ČNB při přípravě vzniku pražské burzy}

Iniciativa SBČS spočívala zejména v tom, že její tehdejší guvernér Josef Tošovský spolu s celým jejím vedením zabezpečil řadu průzkumných jednání v zahraničí, důležitých pro založení burzy cenných papírů.

Výsledkem těchto jednání bylo jednak získání velkého množství informačních materiálů, dokumentů a publikací od navštívených institucí finanční sféry v zahraničí, jednak sjednání několika konkrétních dohod o spolupráci, týkajících se mimo jiné také finančního vzdělávání.

Události tohoto prvního období byly již analyzovány v jiných publikacích, a proto jsou zde doplněny pouze o některé $\mathrm{z}$ dříve neuveřejněných informací a faktů (Pavlát, The Birth of the Prague Stock Exchange, 2015; Pavlát, Prague Stock Exchange (1993-1997), 2018).

\section{2 Úloha Př́ípravného výboru v edukační činnosti (1991-1992)}

Př́pravný výbor zpočátku nevyvíjel prakticky žádnou vysloveně edukační činnost a nepočítal s ní ani v dalším programu v rámci budoucí burzy, nebot' podobná činnost se vymyká okruhu běžných funkcí burzy.

Jedinou, avšak velmi významnou akcí v 1. čtvrtletí 1991 bylo uspořádání série pěti odborných přednášek pro pracovníky bank a spořitelem. ${ }^{34}$

\subsection{Praktický význam aukcí na tzv. prozatímním sekundárním trhu SBČS}

Tento trh SBČS vytvořila v r. 1991 pro banky jako aukční trh obligací. Účastníky trhu bylo 7 bank. Na tomto trhu se obchodovalo především se státními dluhopisy, později také s dluhopisy Komerční banky a Všeobecnej úverovej banky a rovněž s podílovými listy, které emitoval stát, 1 banka, 1 strojírenský podnik, 1 pivovar a 1 investiční společnost. Na prozatímním sekundárním trhu se za dobu jeho existence postupně (v 14denních intervalech) uskutečnilo 37 aukcí; poslední aukce se konala 22. prosince 1992.

\footnotetext{
${ }^{34}$ Tato akce je podrobně popsána v bloku Odborné semináře pro pracovníky bank a spořitelen (březen-červen 1991).
} 
„Za 1,5 roku existence tohoto trhu se zvýšil počet jeho účastníků na 7 a počet emisí na 14.“ (Viz Appendix, Pavlát, Kubíček, Regulace a dozor nad kapitálovými trhy, s. 133.) Jak uvádí A. Kubíček, „Hlavním cílem obchodů na prozatímním sekundárním trhu bylo postupně vytvářet podmínky pro to, aby se banky, investoři a emitenti naučili orientovat na kapitálovém trhu.“ (Tamtéž, s. 133.)

Podmínkou pro účast na aukcích bylo uveřejnění podrobných informací o emitentovi v tisku. Obchodování probíhalo podle pravidel, stanovených SBČS, které odpovídaly tehdejším burzovním pravidlům obchodování s dluhopisy na západoevropských burzách.

Účastníci aukcí pochopitelně museli ovládat techniku aukčních obchodů a museli mít všeobecné znalosti o obchodování na kapitálovém trhu a na burzách. ${ }^{35} \mathrm{Z}$ tohoto hlediska prozatímní sekundární trh splnil očekávání SBČS o jeho potenciálním edukačním vlivu na budoucí pracovníky burzy a členy burzy.

\subsection{Angažovanost centrální banky v oblasti vzdělávání pracovníkủ finanční sféry}

Prostřednictvím svých zástupců v Př́ípravném výboru ČNB prosazovala názor, že pražská burza po svém založení by měla nejen pečovat o finanční gramotnost svých pracovníků, ale také o vytváření příležitostí pro finanční vzdělávání pracovníků vznikajícího finančního sektoru.

Během dalších let se vedoucí funkcionáři ČNB zúčastňovali mnoha významnějších akcí seminářů a konferencí, pořádaných různými institucemi včetně vysokých škol. Tato praxe významně napomáhala šíření finančních poznatků pracovníků finanční sféry i široké veřejnosti.

\section{Blok 9}

\section{Odborné semináře pro pracovníky bank a spořitelen (březen-červen 1991)}

Z iniciativy předsedy Př́ípravného výboru Ing. Miroslava Kučery, vedoucího odboru kapitálového trhu SBČS, byla během března až června 1991 uspořádána série 5 odborných seminářu určených pro pracovníky bank a spořitelen. Měla tyto pracovníky seznámit $\mathrm{s}$ vybranými základními poznatky o obchodování cennými papíry na burzách cenných papírů, s pravidly SBČS pro experimentální obchodování cennými papíry na tzv. prozatímním sekundárním trhu cenných papírů a se zkušenostmi získanými při tomto obchodování probíhajícím v rámci odboru kapitálového trhu SBČS. Organizační přípravu, vypracování zkušebních otázek a pokyny pro závěrečné práce zabezpečovala externě organizace ECONORG (soukromá firma).

V rámci těchto seminářů byly předneseny tyto přednášky:

- Informace o prozatímním sekundárním trhu cenných papírů

- Zásady postupu při obchodování cennými papíry na prozatímním sekundárním trhu

- Zúčtování a vypořádání obchodů na prozatímním sekundárním trhu

- Způsoby stanovení kurzů na burzách cenných papírů

\footnotetext{
${ }^{35}$ Reprezentanti jednotlivých bank nebyli pro svou účast na prozatímním sekundárním trhu speciálně školeni.
} Odpovědnost za správný průběh obchodování plně spočívala na bedrech odboru kapitálového trhu. 


\begin{tabular}{l}
\hline - Systémy vypořádání burzovních obchodů \\
- Stanoviska a doporučení zahraničních expertů k zákonu o burze a ke koncepci burzy \\
cenných papírù v Praze \\
- Jak číst burzovní zpravodajství na stránkách zahraničního tisku \\
- Náležitost a význam prospektů na burze cenných papírů \\
- Mezinárodní standardizace cenných papírů a její aplikace v podnicích ČSFR \\
- První zkušenosti s obchodováním na prozatímním sekundárním trhu \\
- Aktuální informace o stavu příprav na založení burzy \\
Přednášky na semináŕích přednesli členové lektorské skupiny ve složení: \\
Ing. M. Kučera, Ing. A. Vácová, Ing. J. Budík, CSc., Doc. Ing. Vladislav Pavlát, CSc., Ing. \\
I. Vohlmut a dipl. Ing. C. Lusk. \\
Účastníci kurzu po jeho skončení absolvovali písemný test (v rozsahu 17 zkušebních otázek) \\
a museli vypracovat závěrečnou písemnou práci (na téma vybrané ze seznamu předem \\
zveřejněných a schválených témat) a obhájit ji před zkušební komisí. Na základě úspěšné \\
absolvovaného písemného testu a obhajoby závěrečné písemné práce jim byla vydáno \\
osvědčení, které bylo později uznáváno jako prozatímní osvědčení způsobilosti odborníka \\
pro kapitálový trh. Toto osvědčení postupně obdrželi všichni účastníci.
\end{tabular}

Pramen: Archiv IPRFT

\section{Shrnutí}

Centrální banka (SBČS, od r. 1993 ČNB), která po r. 1989 sehrála významnou iniciativní úlohu podporou úsilí o založení nové Burzy cenných papírů, od počátku zdůrazňovala potřebu finančního vzdělání. Po založení tzv. Přípravného výboru podpořila v r. 1991 uspořádání přednáškového cyklu pěti odborných seminářů pro pracovníky bank a spořitelen (březenčerven 1991) o př́pravě založení Burzy cenných papírů a o budoucím vzniku českého kapitálového trhu. Této př́ležitosti bylo využito i ke zjištění úrovně finanční vzdělanosti pracovníků bankovního sektoru.

V rámci činnosti SBČS založila a provozovala tzv. prozatímní sekundární trh, na němž se konaly aukce českých veřejně obchodovatelných obligací. Tato akce měla značný úspěch, nebot' pracovníci bank se mohli blíže seznámit s praxí obchodování s cennými papíry.

V letech 1993-1997 se vedoucí ČNB funkcionáři zúčastňovali významnějších odborných diskusí, seminářu a národních i mezinárodních konferencí. Tato činnost měla značný demonstrační efekt nejen pro pracovníky institucí bankovního sektoru, ale i pro širší veřejnost, nebot' o podobných akcích obvykle informoval i denní tisk a někdy i televize a rozhlas. 


\section{7 Úloha BCPP ve finančním vzdělávání účastníků českého kapitálového trhu}

Účelem této kapitoly je popsat a zhodnotit podíl pražské Burzy cenných papírů na finančním vzdělávání účastníků českého kapitálového trhu - investorů, obchodníků s cennými papíry, ostatních zprostředkovatelů, široké veřejnosti a okruhu pracovníků a spolupracovníků burzy.

Kapitola 7 obsahuje 4 subkapitoly. První z nich (7.1) přináší obecný pohled na očekávanou roli burzy v oblasti finančního vzdělávání. Druhá subkapitola (7.2) se zabývá orientací politiky BCPP v oblasti finančního vzdělávání. Třetí subkapitola (7.3) charakterizuje činnost BCPP v oblasti profesního vzdělávání. Čtvrtá subkapitola (7.4) pojednává o účasti BCPP na akcích jiných institucí k problematice kapitálových trhů a jejich významu. ${ }^{36}$

\subsection{Obecně o očekávané úloze burzy týkající se finančního vzdělávání}

Při př́ípravách na založení pražské Burzy cenných papírů se počítalo s tím, že orgány burzy ponesou odpovědnost nejen za dostatečné profesionální znalosti a dovednosti budoucích pracovníků burzy a pracovníků členských bank a nebankovních obchodníků cennými papíry, ale že burza bude muset do široké veřejnosti vyzařovat informace o svém poslání a o veškerých činnostech spojených s obchodováním. Připomeňme, že se s obchodováním cennými papíry po roce 1990 fakticky začínalo úplně od nuly, takže burza musela veřejnost soustavně přesvědčovat o potřebnosti své vlastní existence i ostatních institucí kapitálového trhu.

Př́ípravný výbor burzy měl již při svém založení k dispozici značné množství kvalifikovaných informací o burzách a kapitálových trzích vyspělých zemí včetně informací o jejich specifických systémech finančního vzdělávání. Tyto informace pocházely zejména z Velké Británie, Francie, Německa, Rakouska, Švýcarska a několika dalších zemí (viz kap. 3). Bylo nezbytné získané poznatky co nejdřive analyzovat a vyhodnotit jejich použitelnost v českých podmínkách. Kapitálové trhy evropských zemí měly - a dodejme, že dodnes mají - specifické zvláštnosti, podmíněné historií jejich vzniku. Bylo zřejmé, že bude věcí zralé úvahy a odvážného rozhodnutí, které zahraniční zkušenosti bude účelné využít, a kterých bude záhodno se raději vystříhat. Již první neúplné analýzy zahraničních systémů plně prokázaly, že žádný z evropských burzovních modelů nebude v českých poměrech možno „vzít, jak leží a běží“ a transplantovat jej do českých poměrů, na druhé straně však zároveň bylo zřejmé, že všechny tyto systémy (modely) mají řadu společných prvků, které je navzájem spojují. Na první pohled bylo např. jasné, že kapitálový trh každé země musí být centrálně regulován určitou autoritou: nejlépe orgánem typu komise pro cenné papíry, zřízeným státem. Mělo být zřejmé i to, že každý vznikající nový trh cenných papíru (emerging market) v transformačních státech nutně bude muset respektovat zavedená a mezinárodně uznávaná pravidla, nebot' by jinak nebyl pokládán za věrohodný a bezpečný. Jakýkoliv vznikající systém obchodování cennými papíry by byl zpochybnitelný, kdyby předčasně zaváděl některé sofistikované produkty (např. finanční deriváty), aniž by získal potřebné zkušenosti a rutinu potřebnou pro provádění běžných burzovních transakcí.

\footnotetext{
${ }^{36}$ Při zpracování této kapitoly bylo využito řady pramenů citovaných v seznamu literatury: BCPP, 1993; Pavlát, 2007; Pavlát, 2008; Pavlát, 2014; Pavlát, 2018; Pavlát, 1992. K úloze BCPP se rovněž vztahují tyto dvě př́lohy: Doplněk k protokolu č. 18 z BK 22. 12. 1993 (res opční burza); Stanovisko BCPP k projektu na založení samostatné opční a termínové burzy v Praze.
} 
Vzhledem k tomu, že téměř nikdo z členů Př́ípravného výboru (kromě Ing. Kavánka, který před studijním pobytem v USA - v ČSOB působil jako makléř) neměl přímé praktické zkušenosti z obchodování s cennými papíry (Pavlát, Prague Stock Exchange, 2018), bylo nutné, aby alespoň část členů Př́ípravného výboru a později i členů Burzovní komory a dozorčí rady si co nejdřrive osvojila potřebné znalosti. Potřebné znalosti získávali průběžně v souvislosti s rozhodováním o aktuální burzovní agendě, a to většinou samostudiem.

Je logické, že systém finančního vzdělávání by měl odpovídat potřebám vznikajícího finančního sektoru (resp. finančního systému). Proto bylo správné, pokud možno hned od počátku se pokusit naučit účastníky vznikajícího českého kapitálového trhu správným, uznávaným, bezpečným praktikám. Bohužel se to dařilo jen v nedostatečné míře. Rychlý spád tehdejších událostí a jejich dramatický průběh i mnoho negativních jevů $\mathrm{s}$ tím spojených neumožnily, aby český kapitálový trh během zkoumaného období let 1990-1998 získal reputaci doporučeníhodného, bezpečného trhu.

\subsection{Orientace politiky BCPP v oblasti finančního vzdělávání}

Politika BCPP v oblasti šíření burzovních informací a v oblasti finančního vzdělávání byla od počátku pragmatická: bylo rozhodnuto soustředit se na základní otázky, mezi které např. patřilo vysvětlení, proč burzy cenných papírů vznikly, jaké jsou základní funkce burzy, s jakými cennými papíry se na burze obchoduje a jak obchodování s cennými papíry na burze probíhá, jak je organizováno vypořádání burzovních obchodů apod. Vysvětlování složitějších otázek muselo být odloženo na pozdější dobu, až burza sama získá dostatek vlastních zkušeností.

Burza si byla vědoma toho, že finanční vzdělávání nepatří mezi její prioritní úkoly, i když toto vzdělání je nesporně důležité. Určitým řešením edukační úlohy - hlavně v prvních dvou letech existence $\mathrm{BCPP}$ - bylo pořádání tiskových konferencí a př́ležitostných shromáždění investorů. BCPP rovněž začala vydávat různé informační bulletiny a propagační materiály. Informace byly vydávány většinou $\mathrm{v}$ omezeném počtu pro členy burzy, a to zpočátku jen $\mathrm{v}$ cyklostylované podobě. BCPP také poměrně brzy po zahájení obchodování začala vydávat tištěný informační časopis „Burza“, určený investorům i širší veřejnosti.

\section{3 Úloha BCPP v oblasti profesního vzdělávání}

Vedení BCPP již před zahájením obchodování (6. dubna 1993) pamatovalo na potřebné odborné vyškolení svých pracovníků. Toto školení mělo tehdy naprostou prioritu; stalo se věcí prestiže burzy. Dva čeští pracovníci burzy byli v předstihu vysláni na stáž na burzu ve francouzském Lyonu, aby si osvojili dovednosti potřebné pro běžný provoz burzy.

Č́st pracovníků BCPP absolvovala kurzy IPRFT (viz podrobně v kap. 9), aby získali makléřský diplom (srov. kap. 4), podobně jako makléři obchodníků cennými papíry, kteří se stali členy BCPP. Technické zaškolení pracovníků burzy, kteří zabezpečovali průběh obchodování prímo na parketu burzy, probíhalo za přítomnosti francouzského instruktora (člena francouzského týmu) a bylo rovněž úspěšně.

\section{4 Účast BCPP na akcích jiných institucí k problematice kapitálových trhů}

Burza se ve sledovaném období let 1993-1998 účastnila různých konferencí, seminářủ, příp. jiných akcí o českém kapitálovém trhu, pořádaných jinými organizacemi nebo institucemi, a to $\mathrm{v}$ různých formách. U některých akcí byla aktivním př́mým spolupořadatelem, u jiných byla 
pouhým účastníkem. Z významnějších akcí, které měly pozitivní dopad na vznik nebo změny legislativy, připomeňme nap̌r. mezinárodní seminář „Podmínky a perspektivy rozvoje kapitálového trhu a burzy v České republice“, který se konal dne 14. ř́jna 1993 v Praze; byl uspořádán ve spolupráci čtyř institucí: BCPP, a.s., IPRFT spol. s r.o., Asociace pro podporu rozvoje kapitálového trhu a Institutu bankovního vzdělávání (podrobnosti v kap. 8).

Blok 10

\section{Specifický problém: obchodování s finančními deriváty}

V r. 1993 byl Ministerstvu financí ČR předložen návrh na založení samostatné Opční a termínové burzy, který zpracovala skupina českých soukromých podnikatelských subjektů společně s 2 členy BCPP (Eastbrokers a BVV) a se švédskou firmou OM (Option Market). Uvedení členové burzy nekonzultovali s BCPP svou účast na projektu opční burzy předem a nesplnili ani svou informační povinnost vǔči burze.

V červnu 1993 vypracoval IPRFT „Memorandum k problematice zavádění a regulování termínových obchodů na současném kapitálovém trhu“, v kterém analyzoval potenciální důsledky předčasného zahájení termínových obchodů na českém kapitálovém trhu a doporučil řadu opatření ve snaze zamezit očekávaný nepř́znivý dopad realizace projektu nové samostatné burzy.

Zástupce IPRFT Ing. O. Zíka zaslal výše zmíněné Memorandum, vypracované v červnu 1993, náměstkovi ministra financí Ing. Purkyněmu dne 23. července 1993.

Z Memoranda jsou zde ocitovány některé pasáže v něm obsažených závěrů a doporučení: „(1) Z hlediska potřeb dalšího rozvoje české tržní ekonomiky je žádoucí, aby se dále postupně vytvářel a stabilizoval český kapitálový trh. (2) ...mezi priority patří především rozvoj promptních obchodů a relativní stabilizace kurzů cenných papírů. Předčasné zahájení opčních obchodů nejen nepatří mezi priority....ale představuje i značné potenciální nebezpečí a vysoké riziko rozvratu vznikajícího kapitálového trhu. (3) Předčasné zahájení opčních obchodů může mít řadu dalších negativních makroekonomických dopadů i mimo sféru kapitálového trhu. (4) Výše uvedená rizika je možno omezit tím, že budou připravena fundovaná dodatečná legislativní opatření $\mathrm{k}$ ochraně investorů ...(a že) zahájení opčních obchodů se časově posune na vhodnou pozdější dobu, kdy se již dostatečně prokáže životaschopnost českého kapitálového trhu...(kdy) budou existovat dostatečné záruky, že instituce zabývající se opčními obchody budou tyto obchody provozovat v zájmu hospodářské, finanční a měnové politiky českého státu ...(kdy) bude garantováno, aby obchodování s deriváty bylo svěřeno do rukou českých subjektů, které nesou hlavní tíhu rozvoje českého kapitálového trhu. (5) Doporučuje se vzít v úvahu skutečnost, že Burza cenných papírů Praha, a.s., při zahájení své činnosti deklarovala záměr ve vhodné době otevř́t trh s deriváty. Burza bude bezpochyby tento záměr realizovat v souladu se zájmy rozvoje českého kapitálového trhu $\mathrm{v}$ intencích politiky uplatňované $\mathrm{v}$ této oblasti Ministerstvem financí, v níž významné místo zaujímá snaha ochránit zájmy individuálních a kolektivních investorů, nepřipouštět snížení likvidity, zabezpečovat transparenci trhu a podporovat rozvoj těch aktivit, nástrojů a forem obchodování, které prrispívají ke stabilizaci trhu a jeho budoucího rozvoje. (6) Z těchto hledisek je účelné posuzovat i časový horizont pro zavedení termínových obchodů na českém kapitálovém trhu. V této souvislosti se nejeví 
jako reálné, že by př́iznivé podmínky pro provozování těchto obchodů mohly vzniknout dříve než po ukončení druhé vlny privatizace, tj. nejdříve $\mathrm{v}$ druhé polovině roku 1994 po uvedení akcií společností privatizovaných $\mathrm{v} 2$. vlně na kapitálový trh a po vytvoření jejich relativně stabilizovaných kurzů.“ (Memorandum, s. 6-7.)

BCPP, a.s., po projednání otázek, spojených sobchodováním deriváty postoupila Ministerstvu financí vlastní návrh zahájení obchodování s deriváty, schválený Výborem pro obchodování a Burzovní komorou a spolu s ním také níže citované zamítavé stanovisko k návrhu na založení samostatné opční a termínové burzy v Praze:

„Burza cenných papírů Praha doporučuje MFČR nevyhovět žádosti o vydání povolení k založení opční a termínové burzy, a dokládá toto své stanovisko důvody uvedenými výše v bodech 1 až 6 Stanoviska. Domníváme se, že BCPP je schopna garantovat, aby obchodování s deriváty nebylo zahájeno předčasně, nýbrž teprve tehdy, až to stupeň rozvoje kapitálového trhu skutečně umožní. Jsme přesvědčeni, že BCPP vzhledem k tomu, že jejími členy je převážná většina licencovaných obchodníků s cennými papíry z ČR, poskytuje i garanci řádného a čestného obchodování s deriváty, až bude tento trh na BCPP otevřen." (Stanovisko BCPP k projektu na založení samostatné opční a termínové burzy v Praze, 23. 7. 1993.)

Mezi důvody, jimiž BCPP odůvodnila své negativní stanovisko, bylo mj. zdůrazněno, že v žádosti o povolení nové burzy nebyl jasně definován předmět jejího podnikání (tj. nebylo zřejmé, že nová burza bude obchodovat pouze s deriváty, ani že bude vyloučen tzv. př́mý př́stup investorů k obchodování bez licencovaných zprostředkovatelů). Ve Stanovisku rovněž bylo zmíněno, že BCPP dá podnět k sankcím proti společnostem Eastbroker a BVV pro závažné porušení členských povinností.

Ministerstvo financí, ČNB, BCPP a také IPRFT v letech 1993-1994 s předstihem zabezpečily výuku základů obchodování s finančními deriváty pro zájemce z řad veřejnosti (kap. 8).

V Příloze k této knize jsou uvedeny tyto dokumenty: Průvodní dopis IPRFT náměstkovi Ministerstva financí ČR Ing. Miroslavu Purkyněmu k „Memorandu k regulaci opčních a termínových obchodů v ČR“ (23. 7. 1993); Stanovisko BCPP k projektu na založení opční a termínové burzy v Praze (návrh z 23. července 1993).

Problematika burzovního trhu s finančními deriváty se počínaje rokem 1995 znovu ocitla středem zájmu určitých zainteresovaných kruhů, které v otevření tohoto nového burzovního trhu spatřovaly možnost rozšíření akčního prostoru pro BCPP, zčásti reflektujícího podobné snahy v řadě jiných zemí s vyspělejšími trhy.

Tato agenda však bohužel př́mo v rámci BCPP nebyla propojena s nezbytným proškolováním potenciálních účastníků nového derivátového trhu (jakožto trhu spojeného se zvýšenými riziky). V kap. 9 jsou $\mathrm{v}$ této knize popsány aktivity společností IPRFT a CMI v oblasti profesního vzdělávání dospělých.

Není však od věci konstatovat, že záležitost burzovních opčních a termínových obchodů se promítla do zájmového střetu různých českých i zahraničních subjektů, nebot' orgány burzy 
sice zahájily přípravná jednání, avšak postupovaly v této záležitosti dosti liknavě. Jednání nového burzovního výboru pro opční a termínové obchody, v němž hlavní slovo měl tehdejší majitel společnosti Patria, nevedlo ani po dvou letech k žádným reálným praktickým výsledkům. Průběh př́pravných jednání se vyostřil natolik, že na základě americké expertízy a vzhledem k neuspokojivým postojům vybrané realizační firmy, vysokým nákladům a obav na rizikovost a nízkou likviditu nového trhu bylo od celého projektu fakticky na poslední chvíli v r. 1998 upuštěno. V archivu BCPP by se jistě o tom nalezlo hodně dokumentů (mj. zápisů z jednání burzovního výboru pro opční a termínové obchody, připravovaných textů burzovních předpisů, znaleckých posudků) jako svědectví nízké akceschopnosti tehdejšího vedení. Pro náš výklad však je nejdůležitější skutečnost, že náš kapitálový trh ani tehdy ještě nebyl dosti zralý pro tak riskantní záležitost, jakou byl daný projekt.

\section{Shrnutí}

Orientace burzovní politiky v otázkách finančního vzdělávání nutně musela být pragmatická (at' již v období př́íprav založení burzy, nebo i po zahájení obchodování v r. 1993), protože problematika finančního vzdělávání nepatřila a objektivně ani nepatří do hlavní náplně činnosti burz cenných papírů.

Finanční vzdělávání účastníků trhu však je nezbytnou podmínkou efektivní činnosti burzy. Burzy v zemích se začínajícími finančními trhy (emerging markets) proto obvykle musí do značné míry suplovat péči o finanční vzdělávání, dokud se tato činnost nestane předmětem podnikání samostatných specializovaných organizací a institucí.

Mezi zásluhy Př́pravného výboru mj. patří to, že se již v r. 1991 pokusil získat dílčí přehled o úrovni finančního vzdělání pracovníků bank, což později napomohlo k nastavení požadavků na získání makléřských licencí (kap. 9).

Burza sama se později již nemohla ověřováním úrovně finančního vzdělání účastníků trhu cenných papírů př́mo zabývat a byla odkázána na poznatky ČNB, MFČR, příp. MŠMT. 


\section{8 Úloha médií v oblasti finančního vzdělávání v ČR}

Účelem této kapitoly je charakterizovat úlohu médií - odborného a denního tisku, televize a rozhlasu - v mimoškolním finančním vzdělávání dospělých v České republice ve sledovaném období a rozebrat vybrané stránky úlohy jednotlivých médií.

Vzhledem ke značnému počtu disponibilních pramenů, zabývajících se otázkami formování českého kapitálového trhu, byla nejprve provedena jejich selekce (cestou odborného odhadu podle zvolených hledisek). Na základě výsledků tohoto odhadu byly vybrány důležité, spolehlivé a vlivné prameny, a poté byla prováděna jejich analýza.

Analýza se soustředila - v souladu s koncepcí této odborné knihy - na mimoškolní finanční vzdělávání dospělých obyvatel ČR, a to především v odborném tisku. Pokud jde o televizní a rozhlasové vysílání, měly být - podobně jako u tiskových pramenů - zkoumány pouze relace věnované mimoškolnímu finančnímu vzdělávání dospělých (viz dále subkap. 8.1 a 8.2).

Některá zobecnění o úrovni finančního vzdělávání ve sledovaném období lze kvantitativně doložit výsledky ojedinělých statistických šetření. Většinou však bylo nutno se spokojit $\mathrm{s}$ odbornými odhady, podepřenými v některých př́ipadech také odbornými názory zahraničních odborníků, kteří se zabývali českým finančním trhem. (Srov. např. kap. 4, o tzv. Millerově zprávě.)

Poznatky získané v této kapitole na základě popisu a hodnocení vybraných mediálních pramenů a vývoji chápání významu úrovně finanční vzdělanosti v ČR mají jak samostatný poznávací význam, tak i význam jako doplnění poznatků z predchozích kapitol (tj. kap. 4, 5 a 6).

Kapitola 8 sestává ze trř́ subkapitol: V subkapitole 8.1 jsou hodnoceny tiskové prameny a jejich měnící se význam během sledovaného období. Obě další subkapitoly se zabývají posouzením využitelnosti archivů Českého rozhlasu (8.2) a České televize (8.3) k analýze pořadů věnovaných finančnímu vzdělávání veřejnosti. Výsledkem studia této otázky je zjištění, že současné uspořádání archivů obou těchto významných institucí neumožňuje z bohatství těchto archivů selektovat nejvýznamnější relace věnované finančnímu vzdělávání veřejnosti a podrobit je analýze ve formě aplikované při rozboru úrovně odborného tisku.

Z tohoto důvodu byl autor nucen ustoupit od svého původního záměru celkové analýzy všech tři médií, podloženého vyhodnocením nejvýznamnějších relací z oblasti finančního vzdělávání veřejnosti, a omezit se pouze na hodnocení úlohy rozhlasu a televize v obecnější rovině (podrobněji viz 8.2 a 8.3 ). ${ }^{37}$

\subsection{Tiskové prameny o mimoškolním finančním vzdělávání dospělých}

V této subkapitole jsou uvedeny doplňující údaje o výběru použitých pramenů o mimoškolním finančním vzdělávání dospělých a charakteristika změn v reakci tisku na aktuální události ve vývoji českého kapitálového trhu a finanční sféry.

\footnotetext{
${ }^{37}$ Pro studium historie českých médií lze doporučit např. publikaci Bednařík - Jirák - Köpplová (2011).
} 


\subsubsection{Poznámky k výběru pramenů a jejich využití}

V kap. 2 bylo pojednáno o pramenech, o zásadách jejich výběru, klasifikace a hodnocení (odst. 2.3.1, 2.3.2 a 2.3.3). V této poznámce jsou doplněna některá důležitá fakta. Vztahují se vesměs ke skupině českých periodik, které se pravidelně věnovaly aktuálním ekonomickým tématům, po prípadě $\mathrm{k}$ př́buzným tématům $\mathrm{z}$ jiných oborů. Nevztahují se $\mathrm{k}$ dennímu tisku, ani k publikacím BCPP, o kterých již bylo pojednáno na jiných místech (např. Pavlát, The PSE Prague, 2018).

V době od počátku 90. let vycházelo několik týdeníků nebo měsíčníků, které se pravidelněji zabývaly - kromě řady dalších ekonomických problémů - otázkami českého kapitálového trhu. Mezi tyto publikace nutno zařadit zejména časopisy Ekonom, Profit, Respekt, Reflex a rovněž dvě specializovaná periodika - měsíčníky ABK a Burzovní analýzy.

V této 8. kapitole - v souladu s jejím zaměřením - je zkoumání úlohy médií v oblasti finančního vzdělávání v ČR zúženo na mimoškolní finanční vzdělávání dospělých. Problémy školského vzdělávání žáků základních a odborných škol, podobně jako otázky finančního vzdělávání studentů vysokých škol musely být ponechány stranou, i když s mimoškolním vzděláváním dospělých souvisí.

S ohledem na technická a jiná omezení (viz výše) byla při volbě pramenů zvolena selektivní metoda. Z časopisecké literatury byly vybrány pouze dva prameny, a to časopis Ekonom a časopis $A B K$. Týdeník Ekonom byl vybrán jako nejčtenější z uvedených periodik a měsíčník ABK pro svou specifickou orientaci na finanční sféru. V této knize bylo dále vhodné a nutné omezit se u týdeníku Ekonom pouze na ročník 1995 jako na rok, kdy se uskutečnila řada velmi důležitých změn na kapitálovém trhu a potvrdila se nutnost celkové reformy. V tomto duchu se nesla analýza edukačního př́nosu Ekonoma v roce 1995. Obdobný postup byl zvolen také u měsíčníku ABK.

Z dosud uvedených důvodů sice nelze tyto analýzy považovat za komplexní, nicméně za dostatečné pro osvětlení úlohy ekonomického tisku ve zkoumaném období.

\subsubsection{Změny v úloze tisku během let 1990-1997}

Český tisk hrál v jednotlivých etapách základního období (srovnej kap. 1, podkap. 1.2) odlišnou úlohu. Během první dílčí etapy prvního základního období nebyla jeho úloha příliš významná. Vesměs šlo o kratší články elementárního osvětového výkladu o různých stránkách vznikajícího českého kapitálového trhu. Po vzniku Př́ípravného výboru pro založení pražské burzy (srov. kap 6.) však jeho vliv na širší čtenářskou obec začal stoupat a také frekvence článků o burze jako novém zajímavém fenoménu postupně rostla. Během druhé dílčí etapy (1993-1994), poté, když Př́ípravný výbor začal pravidelně uveřejňovat informace o své činnosti, řada novinářủ se chopila př́ležitosti ventilovat a komentovat př́ípravy na zahájení činnosti burzy. V té době napřr. začala diskuse o tom, zda bude založena jen jedna („,entrální“) burza v Praze jako hlavním městě Československa, nebo i burza $v$ Bratislavě (dojde-li k rozdělení státu). V úvahu zpočátku připadala i - dosti nepravděpodobná - varianta několika regionálních burz v ČR. Diskutovala se také možnost zavedení elektronické burzy místo tradiční burzy a výběru jejího modelu.

Otázka finančního vzdělávání nebyla v tisku v této dílčí etapě v popředí zájmu. Nezbytností finančního vzdělávání účastníků kapitálového trhu se tisk zpočátku téměř nezabýval. Tato otázka se fakticky stala aktuální až později v r. 1992, hlavně po uzavření smlouvy s Pařížskou 
burzou v r. 1992 a po rozhodnutí MFČR o zahájení makléřských kurzů, v nichž důležitou roli hrála i pražská burza.

Denní tisk vyhlášku MFČR o makléřských zkouškách, uveřejněnou v r. 1992, sice zaregistroval, ale blíže nekomentoval. Podobně tomu bylo i s informacemi o průběhu makléřských zkoušek v pozdějších letech. Pozitivním jevem bylo to, že nedošlo k významnější kritice systému zkoušek, až na několik připomínek neúspěšných uchazečů.

Počátkem druhého období v r. 1993 tisk zpočátku pozitivně hodnotil příznivý rozvoj obchodování na BCPP i v systému RM-S (který byl zákonem o burzách prohlášen za rovnocennou burzu). Brzy však tisk začal informovat také o různých nedostatcích, které se projevily po zahájení obchodování na BCPP a v systému RM-S. Během tohoto roku sice BCPP téměř úplně ovládla regulovaný trh, avšak rostoucí počet obchodů se realizoval na mimoburzovním trhu (tzv. obchody přes Středisko cenných papírů). V tisku byly běžně uveřejňovány informace o nedostatcích v některých zákonech, které umožnily vznik řady podvodů. Mnohých z nich se dopustili obchodníci s cennými papíry a pracovníci útvarů obchodování s cennými papíry v nově založených bankách. (Pavlát, Prague Stock Exchange, 2018.)

Během r. 1994 a rovněž v třetím období vývoje českého kapitálového trhu (1995-1997) se tisk poněkud přiostřil, avšak stále si zachovával kultivovanou formu projevu. Občas se sice vyskytly některé ojedinělé př́ípady emotivních vystoupení, avšak nepřekračovaly únosnou míru.

$\mathrm{Na}$ adresu odborného tisku nutno poznamenat, že se přednostně zabýval obsahovou problematikou českého kapitálového trhu, což je zcela pochopitelné. V jistém smyslu však je méně pochopitelné, že se o různých problémech sice vědělo i psalo, ale spíše ,v rukavičkách“. $\mathrm{V}$ tomto směru byly mnohem př́nosnější konference a semináře, na nichž byly ventilovány mnohé otázky v kritičtějším duchu.

Bylo by zajímavé hlouběji analyzovat příčiny ležérního př́stupu našeho státu k soustavnějšímu prosazování potřeby mimoškolního vzdělání dospělého obyvatelstva a jejího uspokojování. Formálně sice potřeba tohoto vzdělávání nikým nebyla otevřeně zpochybňována, avšak zůstalo se v podstatě při deklaratorních prohlášeních, aniž by se realizovaly potřebné praktické kroky. Úroveň finančního vzdělání ,průměrného občana“ ČR byla v průběhu celého zkoumaného období nedostatečná ve srovnání se žádoucí úrovní ochrany občanů jako potenciálních účastníků kapitálového trhu. Znalosti účastníků finančního trhu mírně převyšovaly republikový průměr, avšak neodpovídaly průměru finančních znalostí zemí s vyspělými finančními trhy. Zároveň však je nepopíratelnou skutečností, že se postupně zvyšovala úroveň finančních znalostí pracovníků přímo činných v oblasti finančního trhu.

K pochopení této složité situace je dobře si uvědomit, že rozvoj finanční sféry postupoval tak překotně, že se česká terminologie z této oblasti vytvářela jen postupně a s velkými potížemi; pro mnohé odborné termíny přebírané z angličtiny nebo i jiných západních jazyků neexistoval vhodný český ekvivalent, který by byl obecně akceptován. 


\section{Exkurz 2}

Edukační př́nos týdeníku Ekonom a měsíčníku ABK k finančnímu vzdělávání

\section{Týdeník Ekonom vycházel v 90. letech jako samostatná př́iloha deníku Hospodářské} noviny pod ISSN 1210-0714.

Do Exkurzu 2 je zařazeno hodnocení ročníku XXXIX. (1995) jako př́íklad jednoho z nejvýznamnějších týdeníků, který měl značný vliv na formování ekonomických názorů v období 90. let. Hodnocení jeho významu pro mimoškolní vzdělávání dospělých se omezuje na otázky týkající se finančních a kapitálových trhů. Je založeno jednak na zkoumání inzertního prostoru, který se těmto otázkám pravidelně věnoval, jednak na přehledu konzultací věnovaných finanční problematice

Týdeník EKONOM v r. 1995 pravidelně v rubrice KARIÉRA - s podtitulem „Kurzy, semináře, školeni'“ - poskytoval prostor pro inzeráty různých vzdělávacích agentur s nabídkou různých vzdělávacích akcí.

V r. 1995 inzerovalo v týdeníku Ekonom (týdeník Hospodářských novin) celkem 14 vzdělávacích agentur. Jejich inzerce vyšly v 41 číslech týdeníku; v 11 číslech rubrika „Kurzy, semináře, školení“ do čísla zařazena nebyla.

V nabídce finančních kurzů figurovalo pouze 35 kurzů s finanční tematikou.

Tab. 1

\section{Základní údaje}

\begin{tabular}{|c|c|c|}
\hline $\begin{array}{l}\text { Počet inzerátů } \\
\text { celkem }\end{array}$ & $\begin{array}{l}\text { Počet výukových } \\
\text { kurzů s problematikou } \\
\text { finančních trhů X/ }\end{array}$ & $\begin{array}{l}\text { Počet vzdělávacích agentur } \\
\text { inzerujících finanční kurzy }\end{array}$ \\
\hline 691 & 44 & 18 \\
\hline
\end{tabular}

Pramen: Ekonom, roč. XXXIX (1995); vlastní sestavení

$\mathrm{x} /$ Do seznamu agentur byly zařazeny agentury, které pořádaly kurzy spojené

s problematikou finančních trhů včetně přípravných kurzy pro zkoušky makléřů.

Většina inzerátů byla velmi stručná; obsahovaly názvy kurzů, název firmy a kontaktem bylo telefonní číslo dané agentury. Existovalo však i několik inzerátů většího rozsahu, které měly upoutat zájem odlišnou podobou. ${ }^{38}$ Počet inzerátů v jednotlivých číslech týdeníků se hlavně $\mathrm{z}$ tohoto důvodu lišil. Rubrice „Kariéra“ byla v týdeníku vyhrazena pouze 1 strana; cena inzerce byla (ve srovnání s jinými týdeníky) relativně vysoká. Inzerci v týdeníku Ekonom větší vzdělávací agentury pokládaly za prestižní záležitost - dávaly tím najevo, že si tuto inzerci „mohou dovolit“. Mnoho menších, zejména lokálních vzdělávacích agentur inzerovalo v regionálním tisku. Inzerci v týdeníku Ekonom proto nelze považovat za měřítko celkového rozsahu (velikosti) nabídky na trhu vzdělávacích služeb; pravděpodobně však představovalo velmi významnou část trhu edukačních služeb.

V tab. 2 je uveden přehled témat kurzů $\mathrm{s}$ finanční tematikou a názvy př́slušných vzdělávacích agentur, které je v r. 1995 nabízely.

\footnotetext{
${ }^{38} \mathrm{~K}$ otázce reklamy autor zpracoval samostatnou studii (dosud neuveřejněno).
} 


\begin{tabular}{|c|c|c|}
\hline \multicolumn{3}{|c|}{ Témata finančních kurzů nabízených v r. 1995 v týdeníku Ekonom } \\
\hline \begin{tabular}{|l|} 
Čís. \\
Eko- \\
nomu \\
\end{tabular} & Název agentury & Název kurzu \\
\hline 1. & 0 & 0 \\
\hline 2. & 0 & 0 \\
\hline 3. & Ekoma Ostrava & Základy finančních operací \\
\hline 4. & 0 & 0 \\
\hline 5. & 0 & 0 \\
\hline 6. & Narex Consult & Nebojte se derivátů \\
\hline 7. & $\begin{array}{l}\text { Sdružení DEM } \\
\text { Stock Consult }\end{array}$ & $\begin{array}{l}\text { Finanční deriváty } \\
\text { Cenné papíry }\end{array}$ \\
\hline 8. & Gradua & Př́íprava k makléřské zkoušce \\
\hline 9. & 0 & 0 \\
\hline 10. & Intermedia Agency & Základy finančních operací \\
\hline 11. & $\begin{array}{l}\text { Eduka } \\
\text { Intermedia Agency }\end{array}$ & $\begin{array}{l}\text { Cenné papíry III } \\
\text { Základy finančních operací }\end{array}$ \\
\hline 12. & $\begin{array}{l}\text { Centrum moderního vzdělávání } \\
\text { Strategie s.r.o. }\end{array}$ & $\begin{array}{l}\text { Základní bankovní znalosti } \\
\text { Metody analýzy cenných papírů }\end{array}$ \\
\hline 13. & $\begin{array}{l}\text { Stock Consult } \\
\text { Nadace Patriae }\end{array}$ & $\begin{array}{l}\text { Technická analýza } \\
\text { Obchodování cennými papíry }\end{array}$ \\
\hline 14. & 0 & 0 \\
\hline 15. & Racio & Finanční analýza \\
\hline 16. & 0 & 0 \\
\hline 17. & Gradua & Základy finančního řízení \\
\hline 18. & 0 & 0 \\
\hline 19. & $\begin{array}{l}\text { Gradua } \\
\text { Cerge-EI } \\
\text { Intermedia Agency Praha }\end{array}$ & $\begin{array}{l}\text { Př́íprava k makléřské zkoušce } \\
\text { Mezinárodní finance } \\
\text { Finanční trhy } 1\end{array}$ \\
\hline 20. & $\begin{array}{l}\text { Stock Consult } \\
\text { IPRFT }\end{array}$ & $\begin{array}{l}\text { Analýza portfolií složených z obligací } \\
\text { Analýza cenných papírů II. }\end{array}$ \\
\hline 21. & Intermedia & Finanční trhy \\
\hline 22. & $\begin{array}{l}\text { Bankovní akademie } \\
\text { Intermedia Agency Praha }\end{array}$ & $\begin{array}{l}\text { Základní bankovní znalosti } \\
\text { Finanční trhy } 3\end{array}$ \\
\hline 23. & Intermedia Agency Praha & Finanční analýza \\
\hline 24. & Intermedia Agency Praha & Finanční trhy 4 \\
\hline 25. & Stock Consult Praha & Financování měst a obcí \\
\hline 26. & 0 & 0 \\
\hline 27. & 0 & 0 \\
\hline 28. & Gradua & Finanční řízení pro ekonomy \\
\hline 29. & Gradua & $\begin{array}{l}\text { Příprava na makléřské kurzy s návštěvou } \\
\text { burzy }\end{array}$ \\
\hline 30. & Gradua & Oceňování firem, tržní hodnota podniku \\
\hline 31. & M. M. Comenius Praha & $\begin{array}{l}\text { Finanční řízení podniku } \\
\text { Finanční analýza, plánování a kontrola }\end{array}$ \\
\hline
\end{tabular}




\begin{tabular}{|c|c|c|}
\hline 32. & Bankovní akademie & Základní bankovní znalosti \\
\hline 33. & Studio W & Finanční řízení firmy \\
\hline 34. & $\begin{array}{l}\text { Studio W } \\
\text { Gradua }\end{array}$ & $\begin{array}{l}\text { Základy finančního managementu } \\
\text { a finančního rozhodování } \\
\text { Finanční řízení pro neekonomy }\end{array}$ \\
\hline 35. & Stock Consult Praha & $\begin{array}{l}\text { Cenné papíry - legislativa } \\
\text { - obchodování - oceňování }\end{array}$ \\
\hline 36. & Sekurkon Praha & $\begin{array}{l}\text { Finanční analýza, investiční } \\
\text { rozhodování firmy }\end{array}$ \\
\hline 37. & $\begin{array}{l}\text { Kredo, s.r.o. } \\
\text { Eduko Praha }\end{array}$ & $\begin{array}{l}\text { Cenné papíry } \\
\text { Cenné papíry II }\end{array}$ \\
\hline 38. & 0 & 0 \\
\hline 39. & 0 & 0 \\
\hline 40. & 0 & 0 \\
\hline 41. & 0 & 0 \\
\hline 42. & 0 & 0 \\
\hline 43. & $\begin{array}{l}\text { Studio Racio } \\
\text { Intermedia Agency Praha } \\
\text { MBA Ostrava }\end{array}$ & $\begin{array}{l}\text { Finanční analýza a plánování } \\
\text { Finance podniku } \\
\text { Finance pro manažery }\end{array}$ \\
\hline 44. & $\begin{array}{l}\text { M. M. Comenius } \\
\text { Intermedia Agency Praha }\end{array}$ & $\begin{array}{l}\text { Finanční řízení podniku } \\
\text { Analýza společnosti obchodovaných } \\
\text { na kapitálovém trhu }\end{array}$ \\
\hline 45. & 0 & 0 \\
\hline 46. & Eduka Praha & Portfolio \\
\hline 47. & 0 & 0 \\
\hline 48. & $\begin{array}{l}\text { Intermedia Agency Praha } \\
\text { Sophia Praha } \\
\text { Eduka Praha }\end{array}$ & \\
\hline 49. & 0 & 0 \\
\hline 50. & 0 & 0 \\
\hline 51. & Bankovní akademie & Základní bankovní znalosti \\
\hline 52. & 0 & 0 \\
\hline
\end{tabular}

Pramen: Ekonom, 1995, č. 19-52; vlastní sestavení.

Většina vzdělávacích agentur, nabízejících kurzy z oblasti financí, se zřejmě orientovala spíše na podnikovou klientelu, méně již přímo na jednotlivé zájemce. Zvolená témata kopírovala aktuální potřeby podnikové praxe, jako je např. účetnictví, daňová agenda, informatika, otázky finančních a kapitálových trhů (cenné papíry, správa portfolia apod.). Rovněž jazyková výuka (vesměs výuka angličtiny) byla hojně zastoupena mezi nabídkou. $\mathrm{Na}$ dalších místech lze uvést např. personalistiku. V našem výčtu ovšem nejde o stanovení přesného pořadí, ale spíše o odhady. Oblast mimoškolní edukace dospělých se zde totiž prolíná s doučováním žáků základních a jiných škol, středoškoláků apod.

V další tabulce je uveden přehled inzerce finančních kurzů, které jednotlivé agentury uveřejňovaly $\mathrm{v}$ jednotlivých číslech týdeníku Ekonom. Tento přehled informuje o tom, že zájem inzerentů byl během sledovaného období nerovnoměrný. Vcelku koresponduje $\mathrm{s}$ tehdejší praxí jednotlivých agentur, spočívající v tom, že inzeráty na jednotlivé kurzy 
obvykle vycházely zhruba 2-3 týdny před datem zahájení jednotlivých kurzů. Rovněž je zřejmé, že v období letních dovolených inzeráty finančních kurzů v příslušné rubrice nevycházely, nebot' během letních měsíců nebyl o finanční kurzy zájem.

Tab. 3

Podíl jednotlivých agentur na nabídce finančních kurzů

\begin{tabular}{|lcc|}
\hline Název agentury & Počet kurzů & Podíl v \% \\
\hline Bankovní akademie & celkem 7 & 15,90 \\
\hline Centrum moderního vzdělávání & celkem 1 & 2,27 \\
\hline Cerge EI & celkem 1 & 2,27 \\
\hline Eduko Praha & celkem 4 & 9,09 \\
\hline Ekoma Ostrava & celkem 2 & 4,55 \\
\hline Gradua & celkem 6 & 13,64 \\
\hline Intermedia Agency Praha & celkem 8 & 18,18 \\
\hline IPRFT & celkem 1 & 2,27 \\
\hline Credo, s.r.o. & celkem 1 & 2,27 \\
\hline M. M. Comenius Praha & celkem 1 & 2,27 \\
\hline MBA Ostrava & celkem 1 & 2,27 \\
\hline Nadace Patriae & celkem 1 & 2,27 \\
\hline Narex Consult & celkem 1 & 2,27 \\
\hline Sekurkon Praha & celkem 1 & 2,27 \\
\hline Sophia Praha & celkem 2 & 4,55 \\
\hline Stock Consult & celkem 4 & 9,09 \\
\hline Studio Racio & celkem 2 & 4,55 \\
\hline CELKEM 18 agentur & Počet kurzů: 44 & $\mathbf{1 0 0}$ \\
\hline
\end{tabular}

Pramen: Ekonom, roč. XXXIX (1995); vlastní propočty.

Z tabulky 3 lze sestavit toto pořadí agentur: První a druhé místo společně obsadila Bankovní akademie a společnost Intermedia. Každá z těchto společností zabezpečovala po 7 finančních kurzech. Třetí a čtvrté místo obsadily společnosti Eduko a Gradua, z nichž každá zabezpečovala po 4 finančních kurzech. Na první čtveřici vzdělávacích agentur tedy připadlo téměř dvě třetiny celkového počtu nabízených finančních kurzů.

V žebříčku 5. místo zaujala firma Stock Konzult (se třemi kurzy), a 6. místo agentura Sophia (se dvěma kurzy). Na zbývající agentury, které zabezpečovaly každá jen po jediném finančním kurzu, připadala cca jedna pětina celkového počtu finančních kurzů.

Z údajů o nabídce finančních kurzů pochopitelně nelze usuzovat na počty frekventantů jednotlivých edukačních akcí, ani na jejich ekonomickou úspěšnost. Údaje o těchto skutečnostech již s největší pravděpodobností nelze rekonstruovat. Jednotlivé agentury záznamy pravděpodobně již skartovaly.

Tyto kvantitativní údaje ovšem nic nevypovídají o kvalitě kurzů, protože se většinou nepodařilo nalézt ani osnovy kurzi̊, ani jména a kvalifikaci přednášejících. (Výjimkou je pouze IPRFT - viz dále v kap. 9.) 
Přestože některé ze vzdělávacích agentur, které v ČR vznikly po r. 1990, dnes ještě existují a úspěšně fungují, během doby došlo $\mathrm{k}$ jejich různým proměnám. Ani Obchodní rejstř́k většinou již neumožňuje rekonstruovat průběh podobných přeměn (např. přeměny spol. s r. o. na akciovou společnost, přechod od podnikání na základě živnostenského listu na spol. s r. o. nebo na veřejně prospěšnou společnost aj.). Nelze ovšem vyloučit, že bádání v této obtížně zmapovatelné oblasti by nepřineslo zajímavé výsledky.

Přínos týdeníku Ekonom ke zvýšení úrovně mimoškolního finančního vzdělávání dospělých lze na základě uvedených údajů rozhodně označit za významný, a to v několika ohledech.

Předně, $\mathrm{v}$ tom, že - jako jeden $\mathrm{z}$ nejvýznamnějších ekonomických týdeníků zařazením rubriky „Kariéra“ poskytl celostátní prostor pro inzerování edukačních akcí, pořádaných vzdělávacími agenturami.

Za druhé, tím, že zařadil do týdeníku pravidelnou rubriku nazvanou „Škola ekonoma“, v níž byly postupně publikovány konzultace vysvětlující vybrané základní pojmy a souvislosti z finanční oblasti. Tyto konzultace redakce zpracovávala podle tehdy oblíbené knihy Tomáše Toepfera a Martina Kápla „Peníze a Vy“ (Prospektrum 1994).

Za třetí, tím, že v každém čísle byly uveřejňovány články o aktuálních otázkách vývoje českého kapitálového trhu a o burzách. Cenné jsou zejména články obsahující nejen pouhý popis existujícího stavu, ale i řadu fundovaných názorů na teoretické i praktické problémy jejich aktuálního i budoucího vývoje.

I když se z dnešního pohledu některé názory o těchto otázkách jeví jako překonané nebo i chybné, zásluhou Ekonoma je to, že se - s větším či menším úspěchem - snažil aplikovat zásadu objektivity a nepřipouštěl (snad až na několik málo výjimek v podobě emotivních „,blogů‘ některých podrážděných čtenářu) zbytečné polemiky. Těmito rysy se Ekonom pozitivně odlišoval od některých jiných ekonomických periodik.

\section{Měsíčník Akcie - Burza - Kapitál (ABK)}

Tento měsíčník byl jednou z mála periodik specializovaných na oblast kapitálových trhů. Vycházel ve vydavatelství Magnet-Press v letech 1993-1994 pod ISSN 1210-2573.

V tabulce 4. je uveden přehled o struktuře obsahu měsíčníku v jednotlivých letech, která se měnila s ohledem na změny podmínek vývoje českého kapitálového trhu. $\mathrm{V}$ tabulce je uplatněno rozdělení publikovaných příspěvků do 3 hlavních skupin: 1. stati; 2. konzultace, 3. informace o akcích (tuzemských a zahraničních konferencích a semináŕích).

Tab. 4

Struktura obsahu měsíčníku ABK (1994-1996)

\begin{tabular}{|l|c|c|c|}
\hline Rok/Název skupiny & 1994 & 1995 & 1996 \\
\hline A. Stati & 18 & 41 & 45 \\
\hline B. Konzultační články & 9 & 14 & 22 \\
\hline C. Informace o akcích & & & 16 \\
\hline
\end{tabular}

Pramen: Měsíčník ABK 1994,1995,1996; vlastní sestavení

Poznámka: údaje zaznamenávají počet článků zařazených do jednotlivých rubrik. 
Z technických a organizačních důvodů se nepodařilo vždy dodržet jednotné názvy jednotlivých rubrik, takže při sestavování této tabulky bylo nutno zařazení př́spěvků do určité rubriky přehodnotit. Kritériem pro rozlišení byla, za prvé, objektivita výkladu (za konzultace nebyly považovány př́íspěvky, v nichž jejich autor nerespektoval obecně uznávaný názor na tu či onu otázku (nebo čtenáře neinformoval o existenci různých názorů na danou otázku); za druhé, způsob výkladu, který měl být srozumitelný pro předpokládané čtenáře. Měsíčník ABK nespadal do kategorie vědeckých periodik, v nichž nebývají publikovány konzultační články.

Redakční rada usilovala po celou dobu vydávání ABK o objektivitu informací, o zachování tolerance k názorovým rozdílům a o co největší otevřenost informací ze světa; cílem této politiky bylo zvýšení úrovně mimoškolního finančního vzdělávání dospělých. Vydavatelství Magnet-Press vydávalo měsíčník ABK ve spolupráci s Institutem pro podporu rozvoje finančního trhu (IPRFT; viz též kap. 9), takže obsah ABK byl koordinován se školením makléřů a $\mathrm{v}$ souladu s požadavky makléřských zkoušek.

Vydávání časopisu ABK bylo na přelomu roku 1996 a 1997 zastaveno v důsledku uvalení konkurzu na bývalý státní podnik Magnet-Press. Paradoxem je to, že hlavní př́íinou tohoto konkurzu byla snaha developerů zmocnit se tř́ budov situovaných na lukrativních místech $\mathrm{v}$ centru města.

Také přínos měsíčníku Akcie - Burza - Kapitál (ABK) ke zvýšení úrovně mimoškolního finančního vzdělávání dospělých v České republice lze na základě výše uvedených údajů označit za značný.

Tento př́nos spočívá za prvé, v tom, že specializace na finanční otázky, především na problematiku vývoje českého kapitálového trhu a burzy, umožnila kolem časopisu ABK soustředit relativně značný počet čtenářủ, kteří bud' již ve finanční sféré pracovali, nebo o zaměstnání v ní usilovali. Motivace obou skupin čtenářu byla mimořádně vysoká, nebot' jejich kariéra do značné míry závisela na tom, zda si osvojí finanční znalosti v dostatečné míře. Časopis ABK - díky orientaci své ediční politiky - jim poskytoval prŕiležitost k nabytí nejen základních finančních znalostí i možnost získání finančních poznatků odpovídajících střední a vyšší úrovni v dané oblasti.

Za druhé. ABK v každém čísle přinášel kvalitní konzultační články k aktuálním otázkám fungování finančních a kapitálových trhů a tendencí jejich vývoje. Tyto konzultace umožňovaly zmenšovat tehdejší značné zaostávání úrovně finančního vzdělávání za zahraničím.

Za třetí, ABK soustavně přinášel informace o dění na kapitálových trzích nejen v tuzemsku, ale také v zahraničí, o nichž jiná periodika (z různých důvodů) neměla zájem informovat. Šlo mj. o mezinárodní konference, semináře apod., jichž se zúčastňovali čeští představitelé finanční sféry (funkcionáři ministerstva financí, ČNB, BCPP, pracovníci obchodníků s cennými papíry, fondů kolektivního investování nebo profesních organizací).

Za čtvrté, mimořádným př́nosem pro informovanost zahraničních odběratelů $\mathrm{ABK}$ byla samostatná osmistránková př́loha v angličtině, nazvaná „The Capital Market in the Czech Republic“. 


\section{2 Úloha Českého rozhlasu v oblasti finančního vzdělávání dospělých}

Současná archivní politika Českého rozhlasu je založena na zásadě, že dochované záznamy rozhlasových relací mají být utříděny tak, aby byly co nejvíce přiblíženy aktuálním zájmům veřejnosti. Tím je v podstatě předurčen obsah portfolia disponibilních pořadů.

Vzhledem k tomu, že dnešní technika a technologie hlasových záznamů je mnohem dokonalejší než byla v 90. letech minulého století, je (mimo jiné i v zájmu komfortu posluchačů) uchované staré záznamy nutno rekonstruovat a přizpůsobit dnešním požadavkům na kvalitu rozhlasového vysílání.

Je pochopitelné, že plošná rekonstrukce všech dochovaných záznamů by si vyžádala náklady převyšující možnosti rozpočtu Českého rozhlasu. Proto je prováděna selekce dochovaných záznamů, která je podřízena hlediskům, stanoveným jednak v souladu s platnými předpisy o rozhlasovém vysílání a o archivaci záznamů, jednak ovlivňována autonomním rozhodováním vedení rozhlasu.

Z výše uvedených skutečností je zřejmé, že původně zamýšlená obsahová analýza rozhlasových pořadů přesahuje stanovený rámec rozsahu naší knihy. Na tomto místě nutno podotknout, že převod zvukových záznamů do tiskové podoby není jednoduchý a je technicky, časově i finančně náročný, takže ve zpracovávané knize nemohl být proveden.

\section{3 Úloha České televize v oblasti finančního vzdělávání dospělých}

Současná archivní politika České televize vychází z obdobných zásad jako výše uvedená archivní politika Českého rozhlasu.

Velmi důležitým z archivních pramenů České televize z období let 1990-1997 je Výroční zpráva z r. 1997 (https://www.ceskatelevize.cz/rada-ct/), která mj. odkazuje na dvoudílnou Ročenku 1997 obsahující rozsáhlý soubor důležitých dokumentů a dalších údajů o České televizi, o Radě ČT aj. ${ }^{39}$

Rada České televize je podle zákona č. 483/1991 Sb., o České televizi, v platném znění, orgánem, jímž se uplatňuje právo veřejnosti na kontrolu činnosti ČT. Rada ČT má patnáct členů, které volí a odvolává Poslanecká sněmovna, a to tak, aby v ní byly zastoupeny významné regionální, politické, sociální a kulturní názorové proudy. První Rada České televize byla ustavena 1. února 1992 a funkční období jejích členů skončilo 31. ledna 1997. ${ }^{40}$

Určitou, byt' jen neúplnou představu o významu vzdělávacích a osvětových pořadů České televize lze získat ze statistik uveřejněných v Ročence $\mathrm{z}$ r. 1997: na všechny pořady této kategorie (včetně pořadů věnovaných finančním problémům) připadalo v r. 1997 pouze 5,9 \% vysílacího prostoru.

\footnotetext{
${ }^{39}$ Včetně zápisů z jednání, zvukového př́mého přenosu zasedání Rady ČT a archivu.

40 Zprávy z jednání Rady jsou př́ístupné na adrese: https://www.ceskatelevize.cz/rada-ct/zapisy-z-jednani/ K dispozici jsou na této adrese zápisy od 1. ledna 1999 do r. 2019.
} 
Tab. 5

Programové typy pořadů ve vysílání České televize v roce 1997

\begin{tabular}{|c|l|c|}
\hline Pořadí & Typy pořadů & Podíl na vysílání v \% \\
\hline 1. & Dramatické (ČT1 + ČT2 dohromady) & 25,2 \\
\hline 2. & Publicistické & 12,9 \\
\hline 3. & Zpravodajské & 11.0 \\
\hline 4. & Dokumentární & 9,1 \\
\hline 5. & Zábavní & 5,4 \\
\hline 6. & Sportovní & 4,8 \\
\hline
\end{tabular}

Pramen: sestaveno podle Ročenky České televize za r. 1997.

Je však známo, že např. některé pořady zachycující diskuse finančních odborníků o aktuálních finančních otázkách byly zařazeny do jiných kategorií vysílání (zprávy, aktuality apod.), což však ze statistik nelze př́mo vyčíst.

\section{Exkurz 3}

\section{Obsah Archivu České televize v r. 1997}

\section{Obsah Archivu České televize v r. 1997}

Archiv České televize v r. 1997 „zajišt’uje jednotný způsob odborné správy písemných, zvukových a audiovizuálních záznamů na všech typech nosičů, vyrobených nebo jinak získaných při výrobě nebo pro potřeby vysílání České televize v Praze. Nejdůležitější část archivních fondů ČT tvoří audiovizuální záznamy, na nichž je v APF uloženo zhruba 160000 titulů. V archivu a dokumentaci zpravodajství je uloženo přibližně 16000 kazet Betacam a U-matic s 24000 záznamy zpravodajských relací z let 1980-1997 a hrubým materiálem a 500 pásů $\mathrm{BCN}$ se sportovními relacemi. V roce 1998 měly být dokončeny přepisy zpravodajských relací $\mathrm{z}$ formátu $\mathrm{BCN}$ a průběžně následoval jejich obsahový popis a vkládání do databáze; bylo tudíž nanejvýš žádoucí, aby si především redaktoři RZ zvykli vyhledávat $\mathrm{v}$ databázi odpovědi na prosté dotazy. Útvar zajišt'uje každodenně do odvysílání poslední zpravodajské relace rešeršní, přepisovou a výpůjční službu, především pro redakci zpravodajství, ale i pro ostatní tvưrčí skupiny České televize. Ve studijní knihovně České televize $\mathrm{v}$ Praze byly rozšířeny návštěvní hodiny, náklady na periodický domácí i zahraniční tisk byly redukovány zhruba o $10 \%$. Do studijní knihovny byl také objednán soubor nejdůležitějších mezinárodních technických norem a doporučení na formátu CD-ROM. Ve videotéce, $\mathrm{v}$ archivu a dokumentaci zpravodajství a v útvarech APF v Brně a Ostravě se používají $\mathrm{k}$ označování kazet $\mathrm{s}$ obrazovými záznamy štítky čárového kódu $\mathrm{v}$ zájmu jednoznačné evidence a rychlejší orientace při odbavování výroby a vysílání. K úkolům videotéky patř́i i čištění a testování telemagnetického záznamu (TMZ). Informatika APF prostřednictvím svých dramaturgů a ostatních pracovníků společně s videotékou a televizní technikou na TMZ 6 a 5 intenzivně pokračuje v přepisech archivních záznamů uložených na dvoupalcovém TMZ na formát Betacam a jejich kontinuálním popisu do databáze. Zhoršující se technický stav těchto nosičů nás vede k rychlému dokončení přepisů. V současnosti jsou přepsány asi tři čtvrtiny stávajícího fondu dvoupalcových záznamů. Informatika také zajišt'uje rešeršní a poradenskou službu pro televizní uživatele, dále je odpovědna za nasazování repríz pořadů do vysílání podle schématu i mimo ně a za výrobu skrytých titulků $\mathrm{k}$ těmto pořadům. $\mathrm{V}$ depozitárích filmotéky bylo opraveno chlazení a podlaha, avšak trval nevyhovující stav klimatu v depozitáŕích negativů v objektu producentských center. Ve 
filmotéce probíhala průběžně výměna starých papírových a plechových krabic za nové plastové, které jsou vyráběny podle světových parametrů. Byla dokončována preventivní ochrana filmového fondu proti plísni. V létě 1997 se pracovníci APF, zejména filmotéky, intenzivně podíleli na záchraně, restauraci a dokumentaci zatopeného filmového archivního fondu a fondu magnetických záznamů z ČT Ostrava. Během dvou letních měsíců bylo v Praze na Kavčích horách ošetřeno a zachráněno cca 500 hodin audiovizuálních záznamů, tj. asi $60 \%$ zatopeného ostravského fondu. Nyní se filmy kompletují a popisují ve filmotéce APF. Pro rekonstrukci magnetických obrazových záznamů vymysleli naši technici naprosto originální postup s upravením starší čističky Recortec a následným přepisem na formát Betacam SP. Ve studiu Ostrava pokračovaly i v roce 1998 přepisy zatopených dvoupalcových záznamů. Pracovníci spisového archivu vkládali do databáze informace o písemných dokumentech uložených ve fondech archivu. Zároveň probíhala vnitřní skartace fondu. Usilovalo se o vyřešení jednotného způsobu klasifikace uchovávání dokumentů trvalé archivní hodnoty, které vznikly a jsou archivovány v systému Word. Fonotéka APF doplnila zvukový fond dalšími CD z produkce Fontána a Awika - TVR Music Partner pro potřeby režisérů ozvučení a mistrů zvuku. Kromě toho byla získána hudební kolekce 100 kusů CD od firmy Arcadia Cosmos pro fonotéku TS Brno. Prostřednictvím Telexportu byly prodány zvukové snímky z produkce České televize několika hudebním vydavatelstvím. V hudebním fondu fonotéky probíhá průběžně hloubková revize fondu a údaje jsou vkládány do databáze“.

Pramen: Charous, Vít. Archiv České televize. In: Ročenka České televize 1998. Díl I., s. $217-$ 218. ISBN 80-85005-17-4.

\section{Shrnutí}

Závěrem této kapitoly na základě výše uvedených poznatků lze konstatovat, že úroveň finančního vzdělání dospělého obyvatelstva v ČR (ve srovnání se zeměmi s vyspělejšími finančními trhy) sice zůstávala nízká, avšak pozitivním jevem je skutečnost, že vlivem médií se úroveň finančního vzdělání dospělého obyvatelstva (bráno jako celek) již od poloviny 90 . let postupně zvyšovala. K nejrychlejšímu růstu úrovně finančních znalostí došlo ve sledovaném období u kategorie dospělých osob, zaměstnaných ve finanční sféře.

I když je sledování a srovnávání míry zvyšování úrovně finančních znalostí dospělého obyvatelstva problematické a podobně problematické je také sledování míry vlivu sledovaných médií (tisku, rozhlasu a televize), podle převažujících názorů autorů z akademické sféry, zabývajících se studiem těchto otázek, hlavním nástrojem pro zvyšování úrovně finančních poznatki se zhruba od poloviny 90. let stal internet.

Během prvních 3-4 let nejdůležitější úlohu hrály informace uveřejňované v tisku. Poté výrazně vzrostla informační úloha televize v oblasti finančního vzdělávání, a úloha rozhlasu slábla. Pokud jde o tisk, hlavní úlohu pro finanční vzdělávání pro dospělé osoby zaměstnané ve finanční sféře i nadále hrál odborný tisk. Výrazně však rostl význam denního tisku pro většinu dospělého obyvatelstva v ČR. Tyto poznatky jsou vesměs podloženy expertními odhady, nebot' většina disponibilních údajů ve statistikách není uváděna v členění umožňujícím separátní vyhodnocení úrovně finančních znalostí dospělého obyvatelstva. 


\section{9 Úloha soukromých vzdělávacích institucí}

V této kapitole je pojednáno o činnosti soukromých vzdělávacích subjektio, jejichž předmětem podnikání bylo v letech 1990-1992 vzdělávání dospělých osob na území bývalého Československa a v letech 1993-1998 na území České republiky.

Tato kapitola obsahuje 3 subkapitoly. V subkapitole 9.1 je pojednáno obecně o činnosti soukromých vzdělávacích subjekti̊ ve sledovaném období let 1990-1998. V subkapitole 9.2 je zařazena př́padová studie (case study) o společnosti Institut pro podporu rozvoje finančního trhu (IPRFT) a v subkapitole 9.3 prrípadová studie o společnosti CMI - Institut pro kapitálový $\operatorname{trh}(\mathrm{CMI})$.

\subsection{Obecně o činnosti soukromých vzdělávacích subjektů v období let 1990-1998}

Když po listopadu 1989 nová vláda ČSFR postupně začala realizovat různá opatření v oblasti soukromého podnikání v rámci přechodu k tržní ekonomice, vyhlášeného ve svém Prohlášení, mezi první její kroky patřila rozsáhlá reforma právních předpisů. Nové předpisy umožnily soukromé podnikání v rodící se finanční sféře.

Zatímco banky dosti dlouho vi̊či novým proudům v podstatě zůstávaly inertní (resp. pokračovaly v do té doby obvyklých formách firemního školení), iniciativní jedinci se začali zajímat i o oblast vzdělávání dospělých, a to hlavně na základě získání živnostenských listů. Tato právní forma podnikání totiž nebyla spojena s nutností vkládat do podnikání vlastní kapitál, ani nevyžadovala prokazování zvláštní způsobilosti k poradenské činnosti, které se mnozí začínající podnikatelé rozhodli věnovat. Většina $\mathrm{z}$ nich začínala podnikat v oblasti obstarávání půjček a úvěrů, záruk v podobě nemovitostí apod.

Jen část z nich začala poskytovat vzdělávací služby; většinou v oblasti jazykové výuky. Výuku ruštiny nahradila angličtina, i když kvalifikovaných učitelů angličtiny mnoho nebylo. Jazykových služeb začali využívat hlavně rodiče dětí povinných školskou docházkou.

Finančnímu vzdělávání dospělých se začali věnovat jednotlivci, kteří měli určitou znalost z oblasti finančnictví v zahraničí, odkud se po r. 1989 jich řada vrátila od Československa. Bohužel někteří z nich své znalosti spíše jen předstírali a snadno nalézali důvěřivé české občany, kteří doufali v rychlé zbohatnutí.

Byli však i seriózní lidé, kteří se začali kromě poradenské činnosti zajímat i o vzdělávání dospělých. Existovaly také některé organizace, jako např. společnost Impulz, a.s., které pochopily, že pro vznik finančního sektoru mezi nezbytné předpoklady jeho rozvoje patři jak získání alespoň základního finančního vzdělání, tak jeho institucionalizace. Proto podporovaly např. myšlenku obnovy pražské burzy cenných papírů nebo plodinové burzy vesměs svými články v tisku apod. Jedním z nadšenců usilujících o vznik dalších mimobankovních finančních institucí byl např̀. Ing. Vladimír Hanuš. Mezi prvními zahraničními stoupenci a podporovateli myšlenky na obnovu pražské burzy byli např. Ing. Jan Zoubek z Belgie, George Vilim z Kanady a další. (Viz Pavlát, V. The Birth of the Prague Stock Exchange, 1. vyd., Didaktis, 2014.) 
Jednou z prvních úspěšných akcí, která vznikla z iniciativy několika členů tzv. Př́ípravného výboru (srovnej výše, kap. 3), bylo uspořádání série přednášek, spojených s diskusí o přípravách k založení pražské burzy cenných papírů.

Teprve po zahájení př́íprav na založení pražské Burzy cenných papírů začaly být v praxi (alespoň slovně) uznávány a aplikovány některé elementární zásady podnikání ve finanční sfére. Zásluhou ČNB a Ministerstva financí ČR (po rozdělení Československa) je to, že tyto instituce postupně začaly prosazovat i vyšší kvalifikační nároky na zaměstnance činné ve finančním sektoru. Je smutné, že v některých př́padech $\mathrm{k}$ tomu došlo opožděně a u poradenství prakticky vůbec ne. Průvodním jevem transformačního procesu se bohužel - mj. i pod negativním vlivem tzv. kuponové privatizace - stala všeobecná honba za penězi, doslova vydlážděná korupcí a podvody (viz Petr Wawrosz, Korupce v redistribučním prostředí - Česká republika, Evropa, svět. Praha, 2016). Slovo „tunelování“ vešlo jako vizitka originálního průběhu české kuponové privatizace do všech evropských jazyků, podobně také slavné heslo „zhasněte světlo“ nebo tzv. útěk před právníky. Podobným heslem z poloviny 90 . let bylo heslo „Nechejte nás vydělávat!“ Plných pět let urputných střetnutí trvalo, než v ČR konečně došlo k založení vrcholného dozorového orgánu kapitálového trhu v podobě Komise pro cenné papíry. Kdyby tato instituce byla založena před kuponovou privatizací a před zahájením obchodování cennými papíry na veřejných trzích - tak, jak jednomyslně, včas a důrazně opakovaně navrhovali zahraniční experti a poradci - mnohým škodám a ztrátám by bylo možno ne-li zcela předejít, tak jejich rozsah alespoň omezit.

V oblasti vzdělávání dospělých se zhruba v polovině 90. let rozšířilo podnikání většinou nedostatečně kvalifikovaných tzv. agenturních zprostředkovatelů a/nebo prímých organizátorů nejrůznějších vzdělávacích kurzů, včetně kurzů z finanční oblasti. Kvalita obsahu ani kvalifikace lektorů $\mathrm{v}$ těchto kurzech často neodpovídala žádoucí úrovni.

S postupným rozšiřováním internetu a počítačové techniky vznikl prostor pro nové živnosti. Někteří poskytovatelé nových služeb (spojených napřs. s uchováváním informací na disketách a s konstruováním a zaváděním různých počítačových programů) nesporně znamenali pro českou ekonomiku prínos.

V některých př́padech však znamenali mj. na kapitálovém trhu určitou hrozbu spojenou se zvýšením rizik.

\section{Shrnutí}

V počátcích prŕíprav na založení pražské burzy, která se stala skutečným symbolem kapitálového trhu, byly představy o formování českého kapitálového trhu dosti neujasněné. Reálnější podobu získaly až po založení tzv. Přípravného výboru v r. 1991, ale hlavně po založení BCPP jako akciové společnosti v posledním čtvrtletí r. 1992. V té době byly již položeny základy legislativy, nezbytné pro založení burzy. Ačkoliv byly dosti vratké, což později vyvolávalo naléhavou potřebu mnoha novelizací, přece jen umožnily praktickou akci, tj. založení burzy. Bez silné podpory ČNB však by pravděpodobně BCPP, a.s., tehdy nevznikla v její tehdejší podobě akciové společnosti; pravděpodobně by byla - po německém a rakouském vzoru - polostátním podnikem s určitým vlivem státu. 
Někteř́ úředníci MFČR, prosazující německo-rakouský model burzy cenných papírů, zpočátku téměř automaticky předpokládali, že stát bude mít v BCPP majoritní podíl. Tento názor se však neprosadil, nebot’ odporoval tehdejší doktríně o správnosti omezování vlivu státu.

V dalších dvou částech této kapitoly je zařazen výklad o činnosti dvou soukromých společností, které objektivně sehrály na poli finančního vzdělávání dospělých během 90. let (zejména v letech 1993-1996) nezanedbatelnou pozitivní roli.

\subsection{IPRFT - Institut pro podporu rozvoje finančního trhu}

V této subkapitole jsou nejprve uvedena základní fakta o společnosti IPRFT (9.2.1). Poté postupně následuje výklad o aktivitách IPRFT v oblasti vzdělávání (9.2.2), v informační, dokumentační a výzkumné oblasti (9.2.3), v oblasti spolupráce IPRFT s jinými institucemi (9.2.4), v oblasti publikační činnosti (9.2.5) a odstavec je zakončen přehledem o seminářích, které společnost ve sledovaném období uspořádala (9.2.6).

\subsubsection{Vybrané údaje o IPRFT}

Institut pro podporu rozvoje finančního trhu (dále IPRFT) vznikl v březnu 1992, tj. ještě před založením BCPP a před rozdělením ČSFR, z iniciativy doc. Ing. Vladislava Pavláta, CSc. a Ing. Zdenka Pavelky jako společnost s ručením omezeným. K nim se jako další společníci s. r. o. připojili Dr. Jiř́i Bureš, Ing. Oldřich Zíka a doc. JUDr. Jarmila Pavlátová.

Toto složení odpovídalo zamýšlené orientaci této společnosti jako jedné z prvních soukromých vzdělávacích a výzkumných organizací ve vznikajícím finančním sektoru ČR, založených ve formě společnosti s ručením omezeným.

Společnost byla založena podle $§ 105$ a následujících ustanovení Obchodního zákoníku jako společnost s ručením omezeným.

Obchodní jméno společnosti v českém jazyce znělo „Institut pro podporu rozvoje finančního trhu spol. s r. o.“; v anglickém jazyce: „Financial Market Development Institute, Ltd.“ Dočasným sídlem společnosti se staly Litoměřice, Liškova 10. Sídlo společnosti bylo později přesunuto do Prahy 1, Školská 16, kde společnost měla pronajaty prostory od společnosti Sport Artis, a.s. V r. 1999 (v souvislosti s konkurzem Sport Artis) společnost IPRFT musela (doslova přes noc!) pronajaté vyklidit, aby tento starobylý dům mohl být prodán cizincům z Mongolska (!).

Podle společenské smlouvy byly jako předmět činnosti společnosti zapsány tři činnosti:

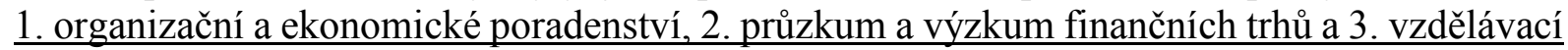
a ediční činnost.

Po prvním roce činnosti společnost opustil Dr. J. Bureš, který se neztotožňoval s politikou nízkých cen produktů IPRFT, a hodlal rozšířit činnost své počítačové firmy CPMM.

Společnost IPRFT dne 17. února 1993 uzavřela z podnětu MFČR s tímto ministerstvem smlouvu o provádění zkoušek makléřù. Tato smlouva převážnou část kapacity činnosti IPRFT orientovala prioritně na školení makléřu, avšak společnosti IPRFT nebránila pořádat jiné 
specializované kurzy (viz Blok „Nabídka vzdělávacích kurzů IPRFT v r. 1993“), ani neomezovala její poměrně rozsáhlou informační, expertní a výzkumnou činnost.

IPRFT se uvedenou smlouvou s MFČR v čl. I. odst. 1 zavázal a) zajišstovat organizaci a technické zabezpečení provádění makléřských zkoušek, včetně jejich vyhodnocení, a to v souladu s vyhláškou MFČR o makléřské zkoušce a závaznými pokyny ministerstva, b) připravovat podklady pro zpracování návrhu zkušebních otázek, jejich další aktualizaci a obměnu s přihlédnutím $\mathrm{k}$ situaci na finančním trhu a k platné právní úpravě, stanovené ministerstvem, c) zachovávat mlčenlivost o všech skutečnostech souvisejících s organizací a technickým zabezpečením makléřských zkoušek. Ministerstvo se v čl. I odst. 2 zavázalo poskytovat Institutu nezbytnou součinnost ve všech náležitostech týkajících se předmětu uvedené smlouvy. Podle čl. IV byla smlouva uzavřena na dobu neurčitou s výpovědní lhůtou 6 měsíců po doručení písemné výpovědi protistraně.

Další smlouva mezi IPRFT a MFČR byla uzavřena v témže roce; jejím předmětem byla vzájemná spolupráce v otázkách, týkajících se rozvoje kapitálového trhu a informovanosti o něm“. V této smlouvě se IPRFT podle čl. I zavázal „....zařadit do své činnosti výzkum a zpracování těch otázek, které jsou potřebné pro činnost Ministerstva (rozuměj: ministerstva financí - V. P.) na úseku dozoru na kapitálovém trhu s přednostním zaměřením na analýzu stavu a vývojových trendů kapitálového trhu a jeho ochranu, vývoj tuzemských majetkových vztahů z hlediska vývojových trendů kapitálového trhu a jeho vztahu $\mathrm{k}$ zahraničí, a to z hlediska ekonomického, právního a organizačně institucionálního.“ Podle čl. II. Smlouvy se IPRFT zavázal a) zajistit v oblasti otázek, tvorrících předmět vzájemné spolupráce širokou informovanost odborné i laické veřejnosti včetně poskytování úplatných konzultačních a poradenských služeb a vzdělávací a publikační činnosti, b) zajistit poskytování informační služby o kapitálovém trhu pro zahraničí, a to jak ve formě informací jednotlivým zájemcům, tak i publikační činnosti a organizováním vědeckých setkání, konferencí a odborných diskusí. MFČR se v článku III. odst. 1 zavázalo, že ,poskytne Institutu všechny potřebné informační prameny, týkající se otázek tvořících předmět této smlouvy“. Podle čl. V byla smlouva uzavřena na dobu neurčitou, s šestiměsíční písemnou výpovědní lhůtou ke konci kalendářního roku.

Společnost IPRFT získala dne 4. června 1993 pověření Ministerstva školství, mládeže a tělovýchovy (MŠMT) na dobu tři let k vydávání dokladů o kvalifikaci po ukončení rekvalifikace ve smyslu vyhlášky MOSV ČR č. 21/91 Sb., resp. ve znění vyhlášky MPSV ČR č. 324/92 Sb. Tato akreditace byla vydána na základě schválení projektu předloženého Ministerstvu školství, mládeže a tělovýchovy (MŠMT) spolu s žádostí o pořádání rekvalifikačních kurzů v oblasti finančního trhu. Podle této akreditace byl IPRFT oprávněn vydávat doklad o ukončení rekvalifikačních kurzů zakončených zkouškou (osvědčení o celostátní platnosti „odborný pracovník finančního a kapitálového trhu“).

V Př́lloze jsou připojeny tyto dokumenty: Žádost o pověření vydávat občanům České republiky doklad o kvalifikaci po ukončení rekvalifikace, adresovaná MŠMT (ze dne 25. 5. 1993); Pověření IPRFT Ministerstvem školství, mládeže a tělovýchovy k vydávání dokladů o kvalifikaci po ukončení rekvalifikace ve smyslu vyhlášky MPSV ČR č. 21/91 Sb., vydané 4. června 1993 s platností do 31. prosince 1996. 
Další obdobné smlouvy o spolupráci IPRFT v roce 1993 uzavřel s Burzou cenných papírů, a.s., s vydavatelstvím Magnet-Press, a.s., a s Českou spořitelnou, a.s. V Př́loze je připojena kopie návrhu smlouvy s Českou spořitelnou o zabezpečení odborného kurzu (z 1. záŕí 1993), jejíž podepsaný originál se nedochoval.

V r. 1993 IPRFT společně s firmou PRO ANO, s.r.o., inicioval založení „Asociace obchodníků s cennými papíry“, která byla v témž roce zaregistrována. V Př́loze jsou uvedeny dokumenty o registraci AOM k datu 4. srpna 1993.

Po sedmi letech úspěšné činnosti, během níž společnost IPRFT dosáhla splnění značné části svých programových cílů orientovaných především na zvýšení kvality českého trhu cenných papírů zvýšením úrovně finančního vzdělání zainteresovaných zájemců z řad finančního sektoru, společnost po vzniku Komise pro cenné papíry od r. 1998 postupně utlumovala svou činnost. Poslední významnou akcí byla účast IPRFT na př́ípravě nových makléřských zkoušek, které přešly do kompetence Komise pro cenné papíry.

V r. 1998 byla ukončena smlouva mezi IPRFT a Ministerstvem financí ČR (resp. Komisí pro cenné papíry). Archivní materiály byly protokolárně předány KCP. V Př́íloze jsou připojeny tyto doklady: Prohlášení IPRFT o vypořádání závazků vůči třetím osobám spojených s makléřskými zkouškami (datovaná dnem 8. února 1999) včetně průvodního dopisu doc. Pavláta předsedovi Komise pro cenné papíry Ing. Františku Jakubovi z 3. února 1999; dále komisionální Zápis o předání 9 krabic obsahující archivované doklady spojené s agendou maklérských zkoušek. Připojen je též návrh předávacího protokolu mezi IPRFT a Komisí pro cenné papíry (dále KCP), upravující proces předávání dokladů o činnosti IPRFT (včetně závěrečné zprávy za rok 1997-1998 a účetních dokladů), který dokumentuje přípravy na ukončení činnosti IPRFT vyplývající z jeho předchozích smluv s Ministerstvem financí, jehož agendu převzala Komise pro cenné papíry.

Společnost po r. 2000 prošla obdobím zdlouhavé likvidace (ovlivněné mj. úmrtím externího účetního) a byla vymazána z Obchodního rejstříku Městského soudu v Praze.

\subsubsection{Aktivity IPRFT v oblasti vzdělávání}

Těžištěm činnosti IPRFT byla od počátku jeho vzniku vzdělávací činnost dospělých, zejména osob, zaměstnaných v podnicích vznikajícího finančního sektoru; některé kurzy byly koncipovány jako rekvalifikační kurzy pro nezaměstnané, kteří se zajímali o zaměstnání v institucích finanční sféry.

V r. 1993 bylo v katalogu nabídky kurzů IPRFT uvedeno celkem 20 různých kurzů lišících se zaměřením na různé uchazeče, obsahem (kurzy obecné povahy nebo specializované kurzy), různou obtížností, odlišnou dobou trvání, odlišnými termíny konání a rovněž cenou. Podmínkou pro konání každého z kurzů uvedených v katalogu byla účast nejméně 15 účastníků (s maximem do 25 osob). Nešlo tedy o hromadné kurzy, nebot' zásadou IPRFT bylo umožnit účastníkům kurzů i bezplatné konzultace po absolvovaném kurzu.

V Bloku 11 je uvedena úplná nabídka kurzů v r. 1993, kdy po zahájení obchodování na BCPP poptávka po finančním vzdělání značně stoupla. 
Blok 11

Nabídka vzdělávacích kurzů IPRFT v r. 1993

\begin{tabular}{|c|l|}
\hline $\begin{array}{c}\text { Č́slo kurzu } \\
\text { katalogu } \\
1993\end{array}$ & $\begin{array}{l}\text { Nabídka kurzů v r. } 1993 \\
\text { NÁZEV KURZU }\end{array}$ \\
\hline 1. & Základní kurz \\
2. & Speciální kurz pro pracovníky zázemí makléřských firem \\
3. & Kurz pro finanční žurnalisty \\
4. & Základní a technická analýza \\
5. & Termínové obchody \\
6. & Základy finanční analýzy I. \\
7. & Základy finanční analýzy II. \\
8. & Základy účetnictví I. \\
9. & Základy účetnictví II. \\
10. & Základy práva v oblasti kapitálového trhu I. \\
11. & Základy práva v oblasti kapitálového trhu II. \\
12. & Investiční společnosti a fondy \\
13. & Základy portfolio investment I. \\
14. & Základy portfolio investment II. \\
15. & Nástroje kapitálového trhu I. \\
16. & Nástroje kapitálového trhu II. \\
17. & Základy bankovnictví \\
18. & Burzovní systémy \\
19. & Jazykové kurzy - burzovní terminologie A, N, Fr \\
20. & Semináŕ - př́íprava k makléřským zkouškám \\
\hline
\end{tabular}

Pramen: archiv IPRFT

IPRFT musel průběžně řešit řadu obsahových a organizačních otázek, zejména kapacitu přednášejících. Značnou část přednášek zajišt'ovali - podle své specializace - společníci IPRFT přímo; na některé kurzy byli jako lektoři přizváni externí odborníci. Lektorský sbor čítal více než 30 osob.

Pro každý kurz bylo nutno zajištovat vhodné prostory odpovídající počtu posluchačů a možnosti instalovat diaprojektor, který byl $\mathrm{v}$ té době hlavní technickou pomůckou. $\mathrm{V}$ přednáškových místnostech obvykle bylo také nutno zajistit tabuli (psalo se křídou). IPRFT byl vybaven vlastními technickými pomůckami. V době, kdy IPRFT spolupracoval s vydavatelstvím Magnet-Press, a.s., bylo mu umožněno na některé kurzy využívat místností této společnosti.

Vzhledem k hlavnímu poslání IPRFT jako vzdělávací instituce, na kterém se při založení společnosti dohodli všichni společníci firmy, byly ceny kurzů udržovány na minimální úrovni, aby bylo možno kurzy nabídnout co nejširšímu okruhu účastníků a přispět tím k rychlému tempu rozvoje finančního sektoru.

V cenách kurzů byla vždy zahrnuta cena učebních pomůcek, nebot' žádný kurz nebyl pořádán bez interních pomůcek IPRFT, aby se účastníci nemuseli zabývat vyhledáváním vhodné literatury. V každé učební pomůcce také byla vždy uváděna doplňková literatura disponibilní v češtině. Většina účastníků kurzů neovládala vznikající českou finanční terminologii, a proto 
součástí nabídky byly také krátkodobé kurzy v angličtině. Kromě toho IPRFT pro potřebu účastníků kurzů připravil terminologické slovníky v angličtině, němčině a francouzštině.

\section{Exkurz 4}

\section{Makléřské kurzy}

E1. Kurz tzv. makléřského minima

E2. Program jednotlivých kurzů uvedených v nabídce kurzů z r. 1993

E3. Vzorek zkušebních otázek (Analýza struktury souborů)

E4. Témata závěrečných prací účastníků kurzů makléřského minima (Analýza)

\section{E1. Kurz tzv. makléřského minima}

Za „makléřské minimum“ byl označován v tehdejším dobovém žargonu soubor znalostí a dovedností, požadovaných ve vyhlášce č./1992 Sb. o makléřské zkoušce a v její Příloze č. 2 za nezbytné pro výkon činnosti maklérù na kapitálovém trhu ČR.

Kurz makléřského minima společnost IPRFT koncipovala především tak, aby odpovídal Př́loze č. 2 výše citované vyhlášky. Tomuto základnímu kritériu byla podřízena všechna ostatní hlediska, spojená s jeho konstrukcí.

V kurzu bylo využito zejména zkušeností ze základního kurzu, který uspořádala firma ECONORG ve spolupráci s Př́pravným výborem burzy již v roce 1991 jako součást kampaně, vysvětlující úlohu burzy v československé transformační ekonomice. Kurz „makléřského minima“ byl koncipován v souladu s obsahem výukových kurzů pro pracovníky finanční sféry v Kanadě, ve Francii a Německu, s přizpůsobením podmínkám na vznikajícím českém kapitálovém trhu i tehdejší nízké úrovni finančního vzdělání.

Kurz makléřského minima obsahoval 4 oblasti, do nichž byly rozčleněny požadované znalosti: (a) kapitálový trh a jeho fungování (7 témat); (b) finanční analýza společností (5 témat); (c) vydávání cenných papírů, jejich úschova a správa (4 témata); (d) burzovní a mimoburzovní obchody.

Pro posluchače nového kurzu „makléřského minima“ byla zpracována a společností IPRFT vydána čtyřdílná příručka „Makléřské minimum“ (s podtitulem „Příručka pro makléře“, v celkovém rozsahu 313 stran). (Viz též dále 9.2.5.) 1. díl této př́ručky obsahoval 3 části: (1) Metodický průvodce k seznamu témat ke zkouškám makléřů; (2) Přehled vybraných vzorců (přehled důležitým vzorců finanční aritmetiky a jejich aplikace; přehled vzorců používaných k finanční analýze; základní účetní (bilanční) rovnice. Autory I. dílu byli doc. V. Pavlát, doc. J. Doležal a doc. P. Záškodný.

II. díl příručky - Základy finančního účetnictví - obsahoval shrnutí elementárních poznatků z oblasti finančního účetnictví (kapitoly: základy finančního účetnictví, účetní závěrka, rozvaha, výkaz zisku a ztrát, účtování o cenných papírech, oceňování, základy rozboru účetních výkazů, výkaz o cash flow, konsolidovaná účetní závěrka). Autorem II. dílu (v rozsahu 72 stran) byl doc. Ing. Jan Doležal, CSc.

III. díl př́ručky - Finanční aritmetika a její aplikace - zahrnoval výklad vybraných základních problémů z oblasti investičního managementu a teorie portfolia. (Obsahoval 11 
kapitol: Č́st 1 - A. Základy finanční aritmetiky - kapitoly 1-5: Úvod, matematické základy, základní rovnice finanční aritmetiky, vzorce finanční aritmetiky a jejich použití; část B., Aplikace finanční aritmetiky 1., kapitoly 6-9: kritéria hodnocení investičních př́ležitostí, investice $\mathrm{v}$ oblasti cenných papírů - krátkodobé cenné papíry, investice v oblasti cenných papírů - obligace, investice v oblasti cenných papírů - akcie, investice v oblasti cenných papírů - termínové obchody s cennými papíry; část 2 Aplikace finanční aritmetiky 2, kapitoly 10-11 (teorie portfolia - hodnocení portfolia, teorie portfolia - výběr portfolia). Autorem III. dílu (v rozsahu 140 stran) byl doc. RNDr. Přemysl Záškodný, CSc.

IV. díl příručky - Kapitálový trh (Vybrané problémy) obsahoval 4 kapitoly: (1) Kapitálový trh - některé důležité pojmy; (2) Průmyslový cyklus; (3) Opce na cenné papíry; (4) Analýza cenných papírů. Autorem IV. dílu (v rozsahu 70 stran) byl doc. Ing. V. Pavlát, CSc.

Pro orientaci posluchačů byla metodická část příručky (díl I. 1) zpracována tak, že ke každé skupině ze 4 témat (viz výše) byl uveden příslušný odkaz na literaturu uveřejněnou v českém jazyce, a to včetně odkazu na příslušnou kapitolu, resp. stránky př́slušných publikací. Posluchači byli informováni, že zkušební otázky nepřekračují rozsah látky uvedené v metodickém průvodci. Kromě odkazů na literaturu byly ke každé kapitole a skupině problémů uvedeny „klíčové pojmy“, které byly excerpovány z pramenů vztahujících se $\mathrm{k}$ dané skupině problémů. Metodická příručka byla vypracována podle doporučení Zkušební komise MFČR pro makléřské zkoušky a Komise pro udělování povolení k obchodování cennými papíry a organizování trhu s cennými papíry v červenci 1993 (tj. před zahájením makléřských zkoušek na podzim téhož roku). Příručku „Makléřské minimum“ IPRFT vydal v srpnu 1993 v prvním ze tří vydání, v nichž postupně byla publikována.

\section{E2. Program jednotlivých kurzů uvedených v nabídce kurzů z r. 1993}

1. Základní kurz pro odborniky kapitálového trhu (Rekvalifikační kurz). Obsah kurzu: Právní předpisy regulující kapitálový trh. Finanční a kapitálový trh. Základní aplikace matematiky a statistiky v oblasti obchodování cennými papíry. Základy burzovnictví. Základy burzovní terminologie (volitelně angličtina, němčina, francouzština). Délka kurzu: 8 dní ve třech soustředěních, vždy v odstupu 14 dní.

2. Speciálni kurz. Kurz je určen pro dealery, analytiky a technickohospodářské pracovníky firem, zejména pro pracovníky zázemí (back-office) makléřských firem.

Cíl kurzu: prohloubit znalosti absolventů základních kurzů a připravit je na práci v zázemí firem obchodníků cennými papíry. Obsah kurzu: Cenné papíry. Úloha obchodníka s cennými papíry. Základní, technická a finanční analýza. Portfolio investment. Organizace a provoz firmy obchodníka cennými papíry. Obchodníci s cennými papíry na burze. Délka kurzu: 6 dní (dvakrát 3 dny) v odstupu 14 dnů. Obtížnost kurzu: středně pokročilí zájemci; vysokoškolské vzdělání ekonomického směru není podmínkou.

3. Kurz pro finanční žurnalisty. Cíl kurzu: předat základní poznatky o finančních a kapitálových trzích, cenných papírech a burze cenných papírů a seznámit účastníky se zkušenostmi finančních žurnalistů v zahraničí. Obsah kurzu: Finanční a kapitálové trhy (teorie); přehled významných trhů ve světě. Základy burzovnictví. Přehled právních předpisů v oblasti kapitálového trhu platných v ČR. Burza cenných papírů v Praze. Práce s prameny 
v oblasti financí, kapitálových trhů a burzy. Na co orientovat finanční rubriku (zahraniční zkušenosti). Délka kurzu: 4 dny (cca 35 hodin). Obtížnost kurzu: předpokládají se základní znalosti z oblasti ekonomiky.

4. Kurz základní a technické analýzy. Cíl kurzu: seznámit účastníky se základy současných analytických metod, aplikovaných v zemích s vyspělými kapitálovými trhy. Obsah kurzu: úvod do základní a technické analýzy včetně ilustrace praktických metod. Kurz je určen pro pracovníky zázemí (back office) obchodníků s cennými papíry a pro soukromé investory spravující vlastní portfolio. Délka kurzu: 3 dny. Obtížnost kurzu: vhodný pro středně pokročilé.

5. Termínové obchody. Cíl kurzu: seznámit účastníky se základy teorie termínových obchodů a s vybranými poznatky z evropské praxe. Obsah kurzu: Základní pojmy. Druhy termínových obchodů. Základy teorie opcí. Vývoj opčních burz v Evropě. Německá termínová burza (DTB). Organizace, pravidla, daňová hlediska. Financial futures. Kurz je určen pro pracovníky front-office obchodníků s cennými papíry, pro pracovníky investičních fondů a pro soukromé investory. Obtížnost kurzu: pro středně pokročilé. Délka kurzu: 2 dny.

6. Základy finančni analýzy I. Cíl kurzu: vyložit základy finanční analýzy podniků a demonstrovat praktickou aplikaci metod této analýzy. Obsah kurzu: Charakteristika finanční analýzy a jejího významu. Zdroje finančních informací. Základní finanční výkazy. Ukazatelé používaní ve světové praxi. Finanční trhy v podniku a mimo podnik. Kurz je určen pro pracovníky zázemí obchodníků s cennými papíry, finančních útvarů podniků, pro soukromé investory, pro koncepční pracovníky bank a fondů. Délka kurzu: 3 dny. Obtížnost kurzu: pro středně pokročilé.

7. Základy finanční analýzy II. Cíl kurzu: prohloubit znalost metod finanční analýzy. Obsah kurzu: Rozbor časových řad ukazatelů finanční analýzy a možnosti předvídání. Techniky a problémy rozborů ukazatelů. Metody oceňování aktiv a pasiv. Efektivnost kapitálového trhu. Metody ohodnocování cenných papírů. Možnost předvídání bankrotů. Právní úprava zveřejňování finančních společností a jejich význam. Státní dozor a jeho úloha. Kurz je určen pro pracovníky finančních útvarů podniků, pracovníků zázemí obchodníků s cennými papíry, pro soukromé investory a pro koncepční pracovníky bank. Délka kurzu: 2 dny. Obtížnost kurzu: pro středně pokročilé, kteří absolvovali kurz „Základy finanční analýzy I.“

8. Základy účetnictví I. Cíl kurzu: seznámit účastníky s novými předpisy a prověřit jejich praktickou aplikaci na účetnictví obchodníků s cennými papíry. Obsah kurzu: Zákon o účetnictví. Opatření FMF o postupu převodu podvojného účetnictví z r. 1992 do r. 1993. Účetnictví obchodníků s cennými papíry (praktické aplikace). Kurz byl určen pro pracovníky back-office firem obchodujících s cennými papíry. Délka kurzu: 3 dny. Obtížnost kurzu: pro začátečníky.

9. Základy účetnictví II. Cíl kurzu: prohloubit praktické znalosti účetnictví získané v kurzu č. 8. Obsah kurzu: účtování obchodů s cennými papíry (praktické aplikace). Kurz byl určen pro pracovníky back-office obchodníků s cennými papíry. Délka kurzu: 3 dny. Obtížnost kurzu: pro středně pokročilé. 
10. Základy práva v oblasti kapitálového trhu I. Cíl kurzu: seznámit účastníky s platným zákonodárstvím v oblasti kapitálového trhu a vysvětlit návaznosti na další důležité předpisy významné pro činnost v této oblasti. Obsah kurzu: Zákon o soustavě cenných papírů. Zákon o burzách cenných papírů. Zákon o investičních společnostech. Zákon o dluhopisech. Obchodní zákoník. Kurz byl určen pro široký okruh zájemců, kteří jsou činní ve finanční a bankovní oblasti, tj. pro pracovníky bank, finančních a daňových úřadů, pro daňové poradce apod. Kurz byl rovněž určen pro pracovníky makléřských firem (a to jak pro makléře, tak pro pracovníky back-office těchto firem, pro soukromé podnikatele, kteří hodlají investovat do cenných papírů, pro pracovníky finančních útvarů firem všeho druhu, které uvažují o vstupu na kapitálový trh i pro individuální investory. Délka kurzu: 3 dny. Obtížnost kurz: nepředpokládá se předběžná znalost právní problematiky.

11. Základy práva v oblasti kapitálového trhu II. Cíl kurzu: Prohloubit znalosti účastníků získané v kurzu č. 10., zejména znalost předpisů BCPP a tržních řádů. Obsah kurzu: předpisy BCPP, a.s. Tržní řády. Vybrané partie ze zákonů vztahujících se nepřímo k problematice kapitálových trhů. Kurz je určen pro široký okruh zájemců, kteří jsou činní ve finanční a bankovní oblasti, tj. pro pracovníky bank, finančních a daňových úřadů, pro daňové poradce apod. Kurz byl rovněž určen pro pracovníky makléřských firem, pro pracovníky finančních útvarů firem všeho druhu, které uvažují o vstupu na kapitálový trh i pro individuální investory. Délka kurzu: 3 dny. Obtížnost kurz: předpokládá se absolvování kurzu č. 10.

12. Investiční společnosti a fondy. Cíl kurzu: seznámit účastníky kurzu s teorií investičních fondů a společností a s praktickými problémy jejich činnosti v České republice. Obsah kurzu: Teorie investičních fondů a společností, právní úprava IPF a investičních společností v ČR. Úloha IPF v kuponové privatizaci. Úloha fondů v rozvoji kapitálového trhu. Problémy strategie rozvoje investičních fondů a společností. Kurz je určen pro pracovníky investičních fondů a společností, pro pracovníky obchodníků s cennými papíry a pro pracovníky finančních útvarů podniků. Délka kurzu 3 dny. Obtížnost kurzu: přepokládají se znalosti v rozsahu základního kurzu.

13. Základy portfolio investment I. Cíl kurzu: poskytnout přehled základních poznatků a metod v oblasti investičního a kapitálového managementu, analýzy rizika a teorie portfolia. Obsah kurzu: Kapitál a jeho výnos (Zisk a faktory, které ho ovlivňují, druhy Cash Flow). Úrokový a diskontní počet (mj. úrokování). Future value, Present value, anuita, perpetuita, tvorba fondů, násobitel, stř́dání. Analýza rizika (faktory rizika, metody kvantifikace Expected utility theory, Mean variance analysis a další). Metody investičního managementu (mj. net Present Value, Internal Rate of Return aj.). Úvod do teorie portfolia (SharpMarkovičův model). Kurz je určen profesionálním investorům, portfolio manažerům, makléřům a pracovníkům peněžních ústavů působících na kapitálovém trhu. Délka kurzu: jeden a půl dne (první den 8 hodin, druhý den 4 hodiny). V př́padě práce s výpočetní technikou 2 dny po 8 hodinách. Obtížnost kurzu: vyžadují se znalosti z ekonomie, matematiky, teorie pravděpodobnosti a statistiky na úrovni absolventa VŠ́.

14. Základy portfolio investment II. Cíl kurzu: poskytnout přehled hlubších a nejnovějších poznatků z oblasti teorie portfolia a kapitálového trhu. Obsah kurzu: Teorie portfolia. Indexové modely. Model kapitálového trhu CAPM při nestandardních předpokladech. Arbitrage pricing theory) - novější paradigma kapitálového trhu. Bond Portfolio Management. Option pricing, teorie spekulace. Kurz je určen finančním specialistům a 
analytikům, pracovníkům zázemí. Délka kurzu: jeden a půl dne. Obtížnost kurzu: vyžadují se znalosti v rozsahu kurzu portfolio investment I.

15. Nástroje kapitálového trhu I. Cíl kurzu: prohloubit teoretické znalosti o nástrojích kapitálového trhu; seznámit se s metodami analýzy cenných papírů. Obsah kurzu: Teorie nástrojů kapitálového trhu. Akcie. Obligace. Analýza cenných papírů. Kurz je určen pro pracovníky zázemí obchodníků s cennými papíry, pro makléře a pro soukromé podnikatele. Délka kurzu: 3 dny. Obtížnost kurzu: pro středně pokročilé.

16. Nástroje kapitálového trhu II. Cíl kurzu: vysvětlit způsob uvádění cenných papírů na trh, správu a úschovu cenných papírů; seznámit účastníky s novými druhy cenných papírů v zahraničí. Obsah kurzu: Právní předpisy upravující emise cenných papírů v ČR k 1. 1. 1993. Zásady uvádění cenných papírů do oběhu. Emise cenných papírů. Požadavky na emisi cenných papírů. Metody stanovení ceny emitovaných cenných papírů. Prospekt. Úschova cenných papírů. Správa cenných papírů. Cenné papíry v zahraničí (nové druhy). Kurz je určen pro pracovníky zázemí obchodníků s cennými papíry, pro makléře a pro soukromé podnikatele. Délka kurzu 3 dny. Obtížnost kurzu: pro středně pokročilé.

17. Základy bankovnictví. Cíl kurzu: zprostředkovat poznatky o úloze finančních institucí v tržním hospodářství. Kurz má u absolventů vypěstovat základní dovednosti a návyky spojené s činností banky a fungováním kapitálového trhu. Obsah kurzu: Úloha bank. Činnosti obchodní a centrální banky. Pasivní a aktivní úvěrové obchody. Úvěr - bankovní obchod. Dokumentární inkaso. Dokumentární akreditiv. Jiné bankovní služby. Kurz je určen pro zájemce o finanční trh, kteří chtějí získat základní znalosti o bankovních obchodech. Délka kurzu: 3 dny. Pro zájemce se základními ekonomickými znalostmi i pro středně pokročilé.

18. Burzovni systémy. Cíl kurzu: seznámit účastníky $\mathrm{s}$ burzovními systémy a mimoburzovními trhy a akcentem na ekonomické a obchodní hledisko. Obsah kurzu: Teoretické problémy systémů burzovního a mimoburzovního obchodu. Přehled soudobých systémů ve světě. Systém pražské burzy; organizace a fungování. Kurz je určen pro pracovníky obchodníků s cennými papíry, pro pracovníky bankovní a finanční sféry, pro pracovníky investičních fondů a společností a pro soukromé investory. Délka kurzu: 3 dny. Obtížnost kurzu: doporučuje se předem absolvovat základní kurz.

19. Jazykové kurzy (angličtina, němčina, př́p. francouzština). Cíl kurzu: procvičit základy burzovní terminologie a seznámit se s reáliemi ze zahraničí, tak aby účastníci byli schopni soustavně studovat zahraniční materiály. Kurz je určen pro všechny zájemce o kapitálové trhy a burzy, kteří se chtějí zdokonalit v jazyku, ovládnout speciální burzovní terminologii a zároveň získat poznatky o zahraničních trzích a burzách. Délka kurzu: 3 dny. Obtížnost kurzu: kurzy bezprostředně navazují na jazykovou výuku v základních kurzech (makléřské minimum).

Poznámka: ve výše uvedených popisech jednotlivých kurzů, které byly převzaty z Katalogu kurzů společnosti IPRFT, vydaného v lednu 1993, byla zachována původní dikce. Např. názvy některých nástrojů, metod nebo produktů byly uváděny v angličtině, protože česká terminologie tehdy nebyla ustálena. Text byl upraven podle platných pravidel českého pravopisu. V Katalogu byl rovněž používán tehdy běžný výraz „makléřská firma“, tj. správně „obchodník s cennými papíry“. 


\section{E3. Vzorek zkušebních otázek (Komentář k př́ípravě otázek)}

V archivu IPRFT se zachovala kopie otázky $\mathrm{C}$ čís. 23 k písemné části makléřské zkoušky, obsahující 200 zkušebních otázek na 41 stranách rozmnoženého textu, opatřená signem IRFT (potvrzení pravosti daného exempláře). (Viz príloha.)

Původní otázky k makléřské zkoušce připravil IPRFT již v r. 1993 po pověření MFČR. Později byly otázky přepracovány a byly schvalovány prŕísl. komisí (viz na jiném místě).

Obsah otázek byl konstruován tak, aby vyhovoval požadavkům MFČR podle př́ísl. předpisů o makléřské zkoušce. Počet otázek byl stanoven na 200. Zkouška probíhala prezenčně pod dohledem určených spolupracovníků IPRFT a MFČR.

Původní otázky vypracoval IPRFT na základě předchozích (většinou písemných) konzultací s několika významnými zahraničními institucemi (např. Canadian Securities Institute, britský úřad SIB, Polská komise pro cenné papíry aj.). Metodika zahraničních vzorů otázek byla modifikována s ohledem na situaci stavu agendy v ČR.

Náročnost makléřské zkoušky předpokládala u uchazečů středoškolské vzdělání, avšak toto vzdělání přímo nevyžadovala. Výsledky zkoušek však prokázaly, že absolventi obchodních akademií byli ve výhodě před absolventy gymnázií; absolventi bakalářského stupně vysokoškolského vzdělání byli ve výhodě před oběma předchozími skupinami. U všech uchazečů však zkouška kladla na přípravu značné časové nároky. Uchazeči, kteří se rozhodli absolvovat kurz makléřského minima, v průměru dosahovali nejlepších výsledků, mimo jiné díky tomu, že téměř na všech uvedených kurzech přednášeli docenti z českých vysokých škol, s nimiž IPRFT úzce spolupracoval.

Přestože IPRFT vydal příručku obsahující učební text k makléřským kurzům (viz Exkurz 3), uchazeči zřejmě přípravu podcenili; značný počet jich propadl. Někteří neúspěšní posluchači reagovali podrážděně tím, že ministru financí adresovali stížnost na př́lišnou př́ísnost IPRFT. (Viz Exkurz 4, odst. 2. Makléřské zkoušky v zahraničí - část 1: Velká Británie (ř́ijen 1993).)

Zásluhou postoje MFČR (konkrétně Odboru dozoru) je to, že několika zahraničním soukromým firmám, které žádaly o povolení ke školení makléřů v ČR, nebyla jejich činnost povolena s odůvodněním, že osnovy jejich kurzů neodpovídají potřebám finanční sféry ČR (konkrétně: zabývaly se praxí obchodování cennými papíry v zahraničí a nerespektovaly stav kapitálového trhu v ČR). Teprve po vstupu ČR do EU některé zahraniční vzdělávací firmy zabývající se problematikou kapitálového trhu mohly v podstatě nekontrolovatelně zahájit svou podnikatelskou činnost. S jistotou nelze posoudit, do jaké míry tato činnost byla (nebo je) prínosem.

\section{E4. Témata závěrečných prací účastníků kurzů makléřského minima}

Součástí makléřských kurzů bylo vypracování a obhájení závěrečných prací. V archivu IPRFT se dochoval původní seznam 1200 témat, z něhož si každý posluchač volil 1 téma.

Na základě rozhodnutí Komise MFČR pro zkoušky makléřů (podle vyhlášky o makléřských zkouškách) posluchačům byla ponechána volba kteréhokoliv z témat uvedených v seznamu témat. Nebyla stanovena formální úprava témat, pouze dolní hranice rozsahu (10 normostran). Práce byly klasifikovány pouze dvěma stupni: „splněno“, resp. „,nesplněno“. Názvy jednotlivých závěrečných prací byly formulovány na základě obsahu vybraných kapitol z „Příručky makléře“ (viz na jiném místě). Závěrečné práce musely být odevzdány 
před závěrečnou zkouškou posluchačů, kteří zkoušku skládali ve vypsaných termínech (skupinu tvořilo obvykle 25 až 30 posluchačů). V tabulce 6 je znázorněn procentní podíl témat zvolených posluchači na celkovém počtu 996 zpracovaných témat.

Tab. 6

\section{Zájem posluchačů o témata závěrečných prací}

\begin{tabular}{lr}
\hline 1. Finanční trhy a burza & 13,15 \\
2. Kolektivní fondy; portfolio & 10,54 \\
3. Burza cenných papírů Praha & 8,64 \\
4. Legislativa & 8,43 \\
5. Finanční trhy a zahraniční burzy & 8,23 \\
6. Cenné papíry & 8,13 \\
7. Privatizace & 6,12 \\
8. Instituce finančního trhu; banky & 4,61 \\
9. Akcie; akciové společnosti & 4,51 \\
10. Burzovní operace & 3,81 \\
11. Finanční analýza & 3,71 \\
12. Termínové obchody & 2,81 \\
13. Obchodníci s cennými papíry & 2.71 \\
14. Finanční modelování & 2,51 \\
15. Obligace & 2,40 \\
16. Depositáŕe & 0,80 \\
17. Prozatímní trh ČNB & 1,70 \\
18. Dozor nad finančním trhem & 0,70 \\
19. Mimoburzovní trh & 0,60 \\
20. Různé & 5,81 \\
\hline
\end{tabular}

Zdroj: Seznam témat závěrečných prací.

Tabulka znázorňuje stupeň „obliby“ 19 témat; do tématu č. 20 „různé“ byla sloučena témata, která byla zpracována pouze jedním nebo dvěma posluchači. Napřr. téma „Marketing obchodování cennými papíry“ zpracoval jen jediný posluchač (!). Téma „Etika obchodování cennými papíry“ byla zpracována pouze dvakrát. Závěrečné práce bohužel nejsou momentálně dostupné (v r. 1999 byly originály odevzdány do Archivu Komise pro cenné papíry).

O tom, proč si některá témata posluchači oblíbili a jiná si zvolili méně často - bohužel - lze jen spekulovat. Se znalostí ,ppsychologie zkoušek“ lze důvodně předpokládat, že nejčastěji si posluchači volili témata, která považovali za snazší, než jiná, obtížnější témata. Pravděpodobná je také domněnka, že napřr. zaměstnanci obchodníků s cennými papíry volili témata, která znali ze své praxe. Téma 17 Prozatímní trh ČNB si zřejmě zvolili přímí účastníci aukcí. Určitou roli nutně hrála i dostupnost literatury. Použitá literatura musela být povinně uvedena $\mathrm{v}$ závěrečné práci. Někteří posluchači dali přednost aktuálním tématům, o nichž se diskutovalo. Více než 200 témat z původních 1200 témat nebylo nikým zpracováno. 


\subsubsection{Aktivity IPRFT v informační, dokumentační a výzkumné oblasti}

Aktivity společnosti IPRFT ve výše uvedených oblastech se v průběhu její činnosti postupně rozvíjely a měnily.

V informační oblasti se změny poptávky po informačních službách měnily v důsledku aktuálních změn na českém kapitálovém trhu, nabídka informačních služeb se snažila držet krok s probíhajícími změnami. Společnost IPRFT od počátku své činnosti shromažd’ovala originální informace o všech kategoriích účastníků kapitálového trhu a zpracovávala je. Uchovávala je vesměs na disketách, které si zájemci mohli zakoupit v sídle společnosti. Od zahájení spolupráce s vydavatelstvím Magnet-Press, a.s., s nímž společnost IPRFT vydávala měsíčník ABK (o tom podrobněji v kap. 7) v letech 1993-1996, byla většina informací o situaci na českém kapitálovém trhu směrována do tohoto měsíčníku.

Dokumentační činnost IPRFT se soustředila na edici „Dokumenty“, v níž byla - v režimu interních informací IPRFT, chráněných autorským právem společnosti - publikována stanoviska IPRFT k aktuálním otázkám, expertizy s návrhy praktických opatření nebo doporučení, obvykle ve zhuštěné podobě několika stránek textu.

Tyto publikace byly zpravidla bezplatně poskytovány významným osobám ve státní správě a v institucích finanční sféry, o jejichž zájmu společnost byla informována z osobních kontaktů. Pouze v př́padě 2 publikací informace nebyla určena pouze pro potřeby VIP. Tyto informace usilovaly o formulování objektivního stanoviska k různým diskusním otázkám, včetně informací o potenciálních rizicích těch či oněch prripravovaných opatření.

IPRFT kromě toho shromažd’oval veškeré právní předpisy týkající se - přímo nebo nepřímo finanční sféry. Tyto předpisy byly využívány při výuce v různých kurzech pořádaných společností. Na požádání byla žadatelům poskytnuta možnost prezenčního studia právních předpisů v prostorách IPRFT.

Výzkumná činnost IPRFT se v podstatě omezila pouze na několik originálních akcí, např. na uspořádání anonymní ankety o názorech nebankovních obchodníků s cennými papíry nebo vydání dvoujazyčné originální příručky o 100 nejvýznamnějších akciových společností v ČR (Kapitálový trh v České republice - The Capital Market in the Czech Republic, IPRFT a Magnet-Press, 1994).

\subsubsection{Spolupráce IPRFT s jinými institucemi}

Od svého založení IPRFT průběžně spolupracoval s řadou institucí, zejména s Ministerstvem financí ČR, s Burzou cenných papírů Praha, a.s., s Asociací pro podporu rozvoje kapitálového trhu, s Asociací obchodníků s cennými papíry a maklérù, s vydavatelstvím Magnet-Press, a.s., v Praze.

S některými z výšse uvedených institucí IPRFT uspořádal společné akce (viz výše 8.2.2) nebo vydal společné publikace (viz dále 9.2.5).

Představitelé IPRFT působili v řadě významných institucí, mj. v Burzovní komoře BCPP a v Komisi MFČR pro makléřské zkoušky. IPRFT byl od r. 1992 zakládajícím členem Asociace pro podporu kapitálového trhu a od r. 1993 zakládajícím členem profesního sdružení Asociace obchodníků s cennými papíry a makléřu. Představitelé IPRFT se stali členy výborů obou 
uvedených organizací. Od r. 1993 byli zástupci IPRFT v představenstvu vydavatelství MagnetPress a dozorčí rady tohoto vydavatelství.

V prŕloze jsou připojeny tyto doklady: Jmenovací dekret z 12. února 1992, jímž ministr financí Ing. Václav Klaus na základě usnesení Finanční rady ČSFR ke koordinaci rozvoje kapitálového trhu jmenoval doc. Ing. V. Pavláta, CSc. členem Komise pro koordinaci rozvoje kapitálového trhu; dále jmenování Doc. Pavláta členem poradní komise MFČR pro udělování povolení k obchodování cennými papíry z 23. října 1992 místopředsedou vlády ČR a ministrem financí Ing. Ivanem Kočárníkem, CSc.; rovněž jmenování doc. Pavláta místopředsedou zkušební komise Ministerstva financí ČR pro provádění makléřských zkoušek z 26. března 1993 místopředsedou vlády ČR a ministrem financí Ing. Ivanem Kočárníkem, CSc.

Spolupráce IPRFT s výše uvedenými organizacemi a institucemi se obsahově soustředila zejména na otázky finančního vzdělávání, avšak zástupci IPRFT se zúčastnili rozhodování orgánů organizací, v nichž byla společnost IPRFT členem a z titulu jmenování rovněž zasedání př́slušných komisí vlády ČSFR a ministerstva financí ČR.

IPFRT udržoval rovněž kontakty s řadou zahraničních institucí, mj. s organizacemi „The Canadian Securities Institute, “ „Proshare“ v Londýně, „Institut bancaire“ v Pařŕži, „Securities Institute“ při americké Komisi pro cenné papíry (SEC) ve Washingtonu, s „Education Development Institute of the World Bank" ve Washingtonu, Förder-Gesellschat für die Börsen und Finanzmärkte" ve Frankfurtu aj. V r. 1994 byla většina těchto kontaktů převedena na paralelní společnost CMI - Institut kapitálového trhu.

\subsubsection{PublikaceIPRFT}

Publikační činnost IPRFT probíhala po dvou liniích:

1. po linii zabezpečování učebních pomůcek pro všechny kurzy; některé z učebních pomůcek byly vydány ve spolupráci s jinými institucemi (viz 9.2.4); 2. po linii informační, výzkumné a expertní činnosti (vesměs pro MFČR a BCPP), vesměs vydávaných ve formě neprodejných interních publikací, určených pro schválený okruh adresátů.

Na počátku své činnosti si IPRFT vytyčil určité zásady pro vlastní publikační činnost, které považoval za velmi důležité pro plnění svého cíle přispět co nejvíce podle svých možností k rozvoji českého finančního a kapitálového trhu v rámci konstituování finanční sféry české ekonomiky, odpovídající v té době existujícím mezinárodním standardům.

IPRFT řešil otázku autenticity a originality své publikační činnosti tím, že vlastním nákladem vydával jednak publikace interního typu (bez ISBN), jednak publikace určené pro pořádané kurzy, konference a semináře (české i mezinárodní), jednak v omezeném počtu výtisků také informace určené pro předem definovaný a schválený počet zájemců, vesměs z okruhu vedoucích pracovníků v institucích finanční sféry (zejména Ministerstva financí, ČNB a členů Burzovní komory BCPP).

V letech 1992-1994 byly vydány tyto pomůcky určené jako literatura pro makléřské kurzy:

- Kolektiv autorů IPRFT. Burza cenných papírů. ANOMAL 1993.

- Pavlát, V. Kapitálové trhy a burzy ve světě. Nakladatelství GRADA, 1992.

- Kolektiv autorů IPRFT. Makléřské minimum. Díly I až IV. IPRFT, 1993 (příručka postupně vyšla ve třech vydáních). 
- Doležal J. - Fireš B. - Miková, M. Finanční účetnictví. Nakladatelství Grada, 1992.

- Pavlát, V. Finanční opce. IPRFT - vydavatelství Magnet-Press, 1994.

- Německo-český a česko-německý slovník odborné terminologie opčních obchodů. IPRFT, interní tisk pro posluchače kurzů makléřského minima, duben 1993.

IPRFT dále (jako interní cyklostylované publikace bez ISBN) publikoval tyto dokumenty a/nebo expertízy:

- „Makléřské minimum“ (1. vyd. 1993).

- „Memorandum k problematice zavádění a regulování termínových obchodů na současném českém kapitálovém trhu“ (červen 1993).

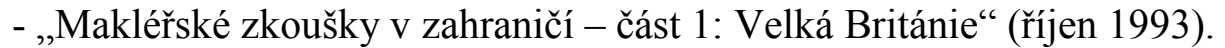

- „Systémy opčních obchodů na opčním trhu MONEP Pařížské burzy“ (listopad 1993).

- „Zásady profesní etiky makléřü“ (listopad 1994).

- „Zásady pro šíření cenově citlivých informací“ (prosinec 1994).

- „Základní standardy chování finančních firem“ (prosinec 1995).

- „Výsledky britského průzkumu postojů významných institucionálních investorů

k portfoliovým investicím ve střední a východní Evropě“ (květen 1995).

- „Zásady regulace obchodování deriváty na českém kapitálovém trhu““(prosinec 1995).

- „Základní standardy chování finančních firem“ (prosinec 1995).

Poznámka: Další publikace byly vydány v rámci dohody o dělbě práce mezi společností IPRFT a společností CMI - Institut kapitálového trhu, spol. s r. o., v období let 1995-1997.

\section{Exkurz 5}

\section{Komentář k obsahu publikací vydaných IPRFT a citace vybraných doporučení IPRFT}

1. Memorandum k problematice zavádění a regulování termínových obchodů na současném českém kapitálovém trhu (červen 1993)

Toto Memorandum IPRFT vypracoval v souvislosti s úvahami o zavedení obchodování s vybranými finančními deriváty a se snahami o založení samostatné Opční burzy. Stručné Memorandum (v rozsahu 7 stran) shrnovalo hlavní argumenty o potenciálních důsledcích předčasného zahájení termínových obchodů na současném českém kapitálovém trhu. Plné znění závěrů a doporučení Memoranda viz Blok 10, s. 54.

\section{Makléřské zkoušky v zahraničí - část 1: Velká Británie (ř́ijen 1993)}

Tato expertíza IPRFT byla vypracována pro ministra financí České republiky Ivana Kočárníka v souvislosti $\mathrm{s}$ uzavřením smlouvy mezi IPRFT a MFČR o pověření IPRFT prováděním makléřských zkoušek a jako reakce na počáteční nízkou úspěšnost uchazečů o makléřský diplom (viz $\mathrm{v}$ Př́lloze), $\mathrm{z}$ nichž si někteří stěžovali na př́lišnou obtížnost makléřských zkoušek.

Zkušenosti Velké Británie byly pro expertízu zvoleny proto, že tato země patří mezi země $\mathrm{s}$ velmi vyspělým kapitálovým trhem a se staletou historií makléřského povolání. 
V expertíze byla popsána část britského systému finančního vzdělávání makléřu včetně systému makléřských zkoušek. Ve Velké Británii jsou pro výkon povolání makléře stanoveny diferencované požadavky, což se promítá do obsahu makléřských zkoušek.

Okruh požadavků a způsob provádění makléřských zkoušek ve Velké Británii určuje SFA (Úřad pro cenné papíry a finanční futures). U této instituce musely být zaregistrovány všechny firmy, které na území $\mathrm{V}$. Británie obchodovaly s cennými papíry, a rovněž určité kategorie osob, které byly zaměstnány u těchto firem, a to: 1. ředitel, 2. společník, 3. výkonný vedoucí (manažer), 4. reprezentant (zástupce) a 5. obchodní zástupce (trader). Kategorie registrovaných zástupců se dále členila podle typu obchodů, které daná osoba bude provádět (cenné papíry, futures a opce, veřejné finance, nástroje peněžního trhu a účastníci trhu s ropou). Kategorie obchodních zástupců byla rozdělena na 6 podskupin. Povinnost skládat zkoušky se vztahovala pouze na 3 první podskupiny (obchody s cennými papíry, peněžní broker a tzv. broker-dealer).

Zkoušky (formou počítačového testu) pro registrované reprezentanty byly trojího druhu: 1 . pro registrované reprezentanty pro oblast cenných papírů, 2. pro registrované reprezentanty pro oblast opcí a futures; 3. pro registrované reprezentanty pro oblast veřejných financí. V expertíze IFRPT byly dále podrobně popsány konkrétní požadavky pro jednotlivé druhy zkoušek ve V. Británii.

Z komentáře IPRFT citujeme: „1. Z přehledu britské praxe je zřejmé, že ve $\mathrm{V}$. Británii je rozsah požadavků na uchazeče všeobecně větší než okruh požadavků stanovených naší vyhláškou o makléřských zkouškách. Není pravdou, že požadavky stanovené Komisí pro makléřské zkoušky MFČR jsou přehnané, ... a $\mathrm{v}$ žádném př́padě nedoporučujeme tyto požadavky devalvovat. 2. Hlavní důraz je kladen na znalost nástrojů, analytických metod, procedur, institucí a celkového mechanismu fungování, nikoliv na znalost právních předpisů ... Nelze tedy doporučit proporci úplně opačnou, protože tím se zkouška dostává do zcela nepřijatelné polohy, kdy by ověření těch znalostí, které tvoří významnou složku makléřovy profesní př́pravy, bylo odsunuto zcela na okraj. 3. Zcela mimořádný důraz je kladen na ovládnutí finančního účetnictví a finanční analýzy, Není pravdou, že makléř nemusí ovládat základy finančního účetnictví a finanční analýzy, nýbrž pravdou je, že tyto znalosti mít musí. 4. do budoucna nutno doporučit diferenciaci zkoušek podle různých kategorií zaměstnanců obchodníků s cennými papíry.“ Komise MFČR se za náročné požadavky na uchazeče jednoznačně vyslovila.

\section{Systémy opčních obchodů na opčním trhu MONEP Pařížské burzy (listopad 1993)}

Tato expertíza (v rozsahu 40 stran) se zabývala výhradně opčními obchody. IPRFT ji vypracoval s využitím originálních dokumentů z MONEP, získaných z Pařížské burzy. Obsah publikace: 1. Úvod; 2. Organizace opčního trhu MONEP; 4. Charakteristika opčních kontraktů; 5. Fungování opčního trhu MONEP; 6. Bezpečnost obchodování na opčním trhu; 8. Systém krytí a jeho výpočet. Publikace dále obsahovala tyto př́lohy: 1 . Statistiky MONEP; 2. Seznam akciových společností zahrnutých do indexu CAC 40;3. Základní transakce s opcemi. 


\section{Zásady profesní etiky makléřu (listopad 1994)}

Tento dokument (v rozsahu 8 stran) obsahoval překlad polského dokumentu „Zásady profesní etiky makléřư (Zasady etyki zawodowej maklerów papierów wartosciowych), který byl v Polsku schválen VI. mimořádným sjezdem makléřů a poradců 24. záŕí 1994 a Radou makléřủ a poradců 29. záŕí 1994.

Polský dokument obsahoval tyto problémové okruhy: 1. Vztahy mezi makléřem a zaměstnavatelem; 2. Vztahy mezi makléřem a klientem; 3. Zachovávání profesního tajemství; 4. Obchodování makléře cennými papíry na vlastní účet; 5 . Rozsah, v němž makléř smí reagovat na události na trhu cenných papírů; 6 . Vztahy mezi makléři.

IPRFT v úvodu uveřejnil svůj komentár̆, v kterém popsal mj. polské zkušenosti z makléřských zkoušek. Tyto zkoušky byly velmi přísné a v letech 1991-1992 je úspěšně složilo pouze cca $15 \%$ uchazečů. IPRFT zde mj. na s. 2 uvedl, že se v otázkách etiky makléřu ..., ,v Polsku zjevně dospělo mnohem dále než v České republice. Je nanejvýš žádoucí, aby u nás co nejdříve došlo $\mathrm{k}$ přesnější reglementaci, která by vnesla jasno do některých otázek (etiky - pozn. V. P.) a omezila výskyt řady nesprávných praktik odporujících občanské i profesní etice.“

\section{Cenově citlivé informace (prosinec 1994)}

Publikace obsahuje český překlad britského oficiálního dokumentu Londýnské „Guidance on the dissemination of price sensitive information“ (London, February 1994). V př́loze této směrnice je uveden výtah z pravidel o kotaci.

Před textem překladu je uveden komentár̆ IPRFT k otázce cenově citlivých informací, který vysvětluje význam stanovení a zachovávání pevných pravidel na vyspělém kapitálovém trhu o tzv. cenově citlivých informacích. $V$ tom, které informace mají být povinně zveřejňovány a které nikoliv. V tomto komentáři se mj. uvádí: „Jedním z důvodů, proč se (český - pozn. V.P.) zákon o cenných papírech omezil pouze na vymezení okruhů elementárních povinností emitentů, spočívá v tom, že nebyla a ani dosud ještě není shoda v tom, které informace mají být povinně zveřejňovány a které nikoliv. Hranici mezi „veřejnými“ a „utajovanými“ informacemi je velmi obtížné vymezit, nehledě na to, že tato hranice může být velmi flexibilní s ohledem na čas: informace totiž zastarávají. "V komentáři je dále vysvětlen pojem tzv. citlivých informací, což jsou veškeré informace, jejichž uveřejnění může ovlivnit kurzy cenných papírů, resp. ohodnocení podniků. Přitom je důležité nejen to, kdy je daná informace uveřejněna, ale i způsob jejího uveřejnění. Směrnice Londýnské burzy o cenově citlivých informací byla vydána jako vodítko pro britské účastníky kapitálových trhů, ale měla značný význam nejen pro investory nebo obchodníky s cennými papíry, ale i na analytiky, novináře atd. po celém světě. Směrnice ,zaujímá mj. stanovisko k zacházení s důvěrnými informacemi, zmiňuje se o využívání výročních zpráv a valných hromad, ...ř̌ší velmi aktuální a delikátní otázku poskytování informací novinářum a vyslovuje se také k problému tzv. zasvěcených osob.“ (Guidance, London, February 1994.)

Na závěr komentáře IPRFT uvedl toto doporučení: „Prostudování tohoto dokumentu naznačuje racionální cestu, kterou by se mělo ubírat myšlení i praxe účastníků českého 
kapitálového trhu, pokud bude pretendovat na to, aby se stal jedním z mezinárodně uznávaných trhů.“

6. Výsledky britského průzkumu postojů významných institucionálních investorů k portfoliovým investicím ve střední a východní Evropě (květen 1995; 11 stran)

Britská firma DEWE ROGERSON (Londýn) uveřejnila 12. 4. 1995 zvláštní zprávu „Attitudes Towards Investment in Central and Eastern Europe“, zpracovanou ve spolupráci s polským deníkem „Rzeczpospolita“ na základě rozhovorů s britskými investičními fondy (5-11. dubna 1995).

IPRFT počátkem května 1995 uveřejnil pod výše uvedeným názvem interní materiál $\mathrm{s}$ vlastním komentářem $\mathrm{k}$ britské speciální zprávě. V první části komentáře byla vysvětlena kritéria, která v té době byla používána při hodnocení kapitálových trhu středoevropských a východoevropských zemí. Z komentáře IPRFT zde volně citujeme některé závěry z britské zprávy týkající se českého kapitálového trhu: „Právní úprava obchodování, vypořádání cenných papírů je považována za neefektivní a nevyhovující“; „,..za hlavní problémy při obchodování na českém kapitálovém trhu je považována likvidita a správa cenných papírů, vypořádání obchodů a nedostatek informací“; „transparentnost českého kapitálového trhu měřeno kvalitou informací je nižší než v Polsku a Mad'arsku“; „za málo dostupné jsou považovány informace o finanční situaci českých podniků“; „britští investoři při realizaci obchodů s českými cennými papíry dávají přednost britským obchodníkům, popř. zahraničním obchodníkům lokalizovaným v České republice před službami domácích českých obchodníků.“ IPRFT uzavřel svůj komentář slovy, že jsou „výsledky britského průzkumu ... jasným varováním a nepřehlédnutelným signálem $\mathrm{k}$ tomu, aby se potřebné legislativní, strukturální a institucionální změny již dále neodkládaly.“

7. Zásady regulace obchodování deriváty na českém kapitálovém trhu (prosinec 1995; 13 stran)

Tuto expertízu IPRFT vypracoval pro BCPP na smluvním základě. Obsah expertízy: 1. Úvod; 2. Zásady regulace obchodování deriváty cenných papírů doporučené mezinárodními organizacemi; 3. Základní podmínky nezbytné pro zahájení obchodování deriváty cenných papírů v České republice; 4. Aplikace mezinárodně doporučených zásad pro regulaci obchodování deriváty cenných papírů v ČR; 5. Posouzení studie proveditelnosti zavedení obchodování deriváty na BCPP, a.s., vypracované firmou PROM; 6. Závěrečné shrnutí a doporučení. IPRFT studii proveditelnosti doporučil jako východisko pro další práce, s výhradou navržených úprav, a zároveň s tím, že ,„český kapitálový trh dosud nedosáhl takového stupně zralosti, který by zaručil pravděpodobnost uspokojivé úspěšnosti obchodování deriváty srovnatelné s úspěšností obchodů tohoto druhu na jiných evropských trzích. “ IPRFT rovněž zdůraznil svůj názor, že je nanejvýš žádoucí, aby MFČR ,zachovávalo i nadále $\mathrm{s}$ ohledem na mezinárodní zkušenosti $\mathrm{v}$ oblasti obchodování deriváty potřebnou obezřelost a nepřipustilo, aby se zavedení těchto obchodů na burze cenných papírů uspěchalo.“

\section{Základní standardy chování finančních firem (prosinec 1995; 31 stran)}

Tato interní publikace IPRFT byla určena jako informační materiál pro vedoucí pracovníky obchodníků s cennými papíry. Obsahem této publikace byl český překlad těchto důležitých 
zahraničních dokumentů: 1. Principy doporučené Mezinárodní komisí pro cenné papíry (IOSCO); 2. Principy doporučené Mezinárodní burzou cenných papírů (FIBV); 3. Pravidla SFA (Conduct of Business Rules); 4. Zásady profesní etiky makléřů v Polsku; 5. Memorandum firmy Morgan Stanley o obchodování zaměstnanců.

K této publikací IPRFT předeslal obsažný úvod ( 5 stran), v kterém formuloval svá stanoviska k vybraným aktuálním otázkám rozvoje českého kapitálového trhu - v otázce jeho legislativního rámce, institucionální infrastruktury a chování jeho účastníků. Odůvodnil zde návrhy, které IPRFT již předložil při různých př́íležitostech a na různých úrovních. Vydání této publikace IPRFT odůvodnil takto: „Smyslem tohoto výběru ze zahraničních dokumentů je uvést v širší známost fakta o požadavcích na standardní chování finančních firem v okruhu profesionálů $\mathrm{z}$ řad obchodníků s cennými papíry.“ “..,,V dokumentech uveřejněných $\mathrm{v}$ tomto materiálu jsou obsaženy některé standardní přistupy uplatňované v zahraničí, které mohou sloužit jako model pro chování těch českých obchodníků s cennými papíry, kteří se rozhodnou cílevědomě preferovat zájem o dlouhodobou úspěšnost českého kapitálového trhu jako celku před jinými časově omezenými cíli.““

9. Průzkum názorů vybraných obchodníků s cennými papíry na aktuální problémy českého kapitálového trhu (leden 1996; 28 stran)

IPRFT prováděl uvedený průzkum v posledním čtvrtletí r. 1995; výsledky průzkumu uveřejnil v lednu 1996. Hlavním cílem průzkumu bylo „,př́spět k objektivizaci názorů na současný stav českého kapitálového trhu a problémy spojené s jeho dalším rozvojem“. Mezi vedlejší cíle patřilo ověření názorů nebankovních obchodníků cennými papíry na fungování některých institucí (např. SCP), zjistit míru ochoty respondentů sdělit vybrané informace o firmě $\mathrm{v}$ souvislosti s rostoucími nároky $\mathrm{v}$ oblasti informační povinnosti a posoudit připravenost firem na obchodování s deriváty na veřejném trhu. Průzkum byl omezen na nebankovní obchodníky ( $\mathrm{s}$ ohledem na neochotu bank zúčastnit se průzkumu, odůvodněnou nutností dodržování bankovního tajemství). Průzkumu se zúčastnilo 65 respondentů (z oslovených 69 firem). Průzkum byl proveden formou anonymní ankety, byl respondentům rozeslán poštou a zpět doručován rovněž poštou. Výsledky šetření zpracovávala na zakázku nezúčastněná osoba.

\section{Obsah vydané publikace}

Část 1. Všeobecná charakteristika průzkumu; Část 2. Způsob hodnocení výsledků průzkum; Část 3. Konkrétní výsledky průzkumu; Část 4. Celkové zhodnocení výsledků průzkumu a jeho výsledků; Část 5. Širší souvislosti průzkumu.

Vybrané výsledky průzkumu (str. 9). V souboru nebankovních respondentů (100\%) 57,82 $\%$ př̀edstavovaly střední podniky; $61,19 \%$ zaměstnanců bylo zaměstnáno v malých podnicích do 5 zaměstnanců; 64,62 \% obchodníků působilo mimo Prahu; 89,2 \% obchodníků mělo úplnou licenci; 60 \% respondentů nebyli členy BCPP; $72 \%$ respondentů nebyli členy Asociace obchodníků a makléřů.

Průzkum potvrdil, že český kapitálový trh byl koncem r. 1995 v počátečním stadiu vývoje. Zpráva uvádí, že se rozvíjí „velmi dynamicky, avšak poněkud asymetricky. Vykazuje řadu anomálií, z větší části vyvolaných specifickým způsobem jeho vzniku.“ (S. 22 Průzkumu.) 


\subsubsection{Semináře IPRFT}

Mezinárodní seminář „Podmínky a perspektivy rozvoje kapitálového trhu a burzy v České republice" se konal dne 14. ř́jina 1993 v Praze. Byl uspořádán ve spolupráci s BCPP, a.s., a s Asociací pro podporu rozvoje kapitálového trhu Institutem bankovního vzdělávání.

Na semináři byly předneseny tyto referáty: Současný stav a perspektivy rozvoje finančního trhu v ČR (Ing. Miroslav Kučera, člen BK a Bankovní rady ČNB); Současný stav a perspektivy rozvoje kapitálového trhu v ČR (doc. Ing. V. Pavlát, CSc. člen BK a předseda výboru pro obchodování); Význam členství v BCPP a hlavní úkoly členů v dalším rozvoji burzy (Ing. J. Klapal, člen BK a předseda výboru pro členské otázky); Současný stav a perspektivy rozvoje informačního systému BCPP (Ing. Jiří Franc, generální tajemník BCPP); Právní rámec rozvoje kapitálového trhu a burzy v České republice (Dr. Ing. Václav Školout, vedoucí právního oddělení BCPP); Profesionalita makléřů - významná podmínka účinné ochrany investorů (Ing. V. Novotný, CSc., předseda představenstva PRO ANO, a.s.); Cesty ke zvyšování kvalifikace maklérů (Ing. Oldřich Zíka, IPRFT); Úloha státního dozoru na kapitálový trh a burzu (Doc. Ing. Antonín Kubíček, CSc., vedoucí oddělení dozoru MFČR); Obchodník s cennými papíry a jeho odpovědnost vůči investorům a kapitálovému trhu (Ing. Ivan Rajda, předseda představenstva EFEKTA, a.s.).

Seminář „Základní východiska pro efektivnějši fungování kapitálového trhu v ČR“ se konal dne 15. února $1995 \mathrm{v}$ Praze. Byl připraven ve spolupráci s Asociací obchodníků cennými papíry a makléřu (AOM)

Na semináři byly předneseny tyto referáty: Jaký model trhu potřebuje česká ekonomika (doc. Ing. V. Pavlát, CSc., IPRFT, BCPP); Co očekáváme od reformy Střediska cenných papírů (Ing. V. Kaucký, CSc., PRO ANO, a.s.); Jak funguje vícestupňový registr a v čem jsou jeho výhody (Ing. P. Slosiarik, Dominick and Dominick Praha); Registr cenných papírů z pohledu zahraničních investorů a aspekty safe-custody v našich současných podmínkách (Mgr. J. Bárta a Mgr. P. Vlasák - ČSOB); Proč český kapitálový trh potřebuje vlastní clearingovou instituci (Ing. P. Koblic, Živnostenská banka). ${ }^{41}$

V Př́loze jsou uvedeny dokumenty o akcích, které byly organizovány ve spolupráci IPRFT s dalšími institucemi během období 1993-1996. Jsou to tyto dokumenty: Program semináře „Podmínky a perspektivy rozvoje kapitálového trhu a burzy v ČR“, uspořádaného ve spolupráci IPRFT a BCPP, Asociací pro podporu rozvoje kapitálového trhu (AOM) a Institutem bankovního vzdělávání dne 14. ř́jna 1993; Program semináře „Základní východiska pro efektivnější fungování kapitálového trhu“ dne 15. února 1995, který společně s IFRFT uspořádala AOM; Seznam účastníků konference IPRFT „Zkušenosti obchodníků s cennými papíry, fondů a obchodních společností s praktickou aplikací novel zákonů regulující kapitálový trh ČR" konaný dne 28. listopadu 1996.

\footnotetext{
${ }^{41}$ Řada přednesených př́spěvků byla uveřejněna v časopise ABK v úplném nebo zkráceném znění.
} 


\section{Shrnutí}

Společnost IPRFT byla ve sledovaném období prakticky jedinou firmou, která se na základě smluv s MFČR a MŠMT specializovala na mimoškolní finanční vzdělávání dospělých podle programů, schválených těmito ministerstvy. V letech 1993-1997 absolvovalo „Kurz makléřského minima" cca 4500 posluchačů, kteří získali tzv. makléřskou licenci. Nezanedbatelná rovněž byla informační a publikační činnost IPRFT.

K formování českého kapitálového trhu přispívala nejen výuková činnost IPRFT, ale také pořádání seminářů, na nichž bylo možno diskutovat o různých nevyjasněných otázkách.

První z významných seminářů IPRFT v r. 1993 měl v podstatě informativní charakter. Jeho účastníci - hlavně z řad pracovníků bankovní sféry - byli seznámeni se vznikající institucionální soustavou českého kapitálového trhu a s hlavními úkoly jednotlivých institucí. Druhý seminář (r. 1995) uspořádaný ve spolupráci s Asociací obchodníků cennými papíry a makléřu (AOM) měl značný význam v diskusích o budoucím vývoji českého kapitálového trhu a jeho výsledky obsahující řadu pozitivních námětů byly uveřejněny $v$ odborném tisku (odborný měsíčník „Akcie - Burza - Kapitál“).

Doporučení príjatá účastníky semináře (zveřejněna i v odborném tisku) a zaslaná různým orgánům státní správy měla vliv na pozdější rozhodnutí vlády o dílčí reformě kapitálového trhu v ČR.

Průzkum potvrdil, že český kapitálový trh byl koncem r. 1995 v počátečním stadiu vývoje. Zpráva uvádí, že se rozvíjí „velmi dynamicky, avšak poněkud asymetricky. Vykazuje řadu anomálií, z větší části vyvolaných specifickým způsobem jeho vzniku“".

\subsection{CMI - Institut pro kapitálový trh}

Tato subkapitola je věnována čtyřem tematickým okruhům. Prvním z nich je charakteristika společnosti Capital Market Institute, spol. s r. o., v níž jsou uvedena vybraná data o jejím vývoji (9.3.1). Poté následují údaje o mezinárodních kontaktech této společnosti v letech 1995-1998 (9.3.2). Třetí část výkladu je věnována seminářům, které společnost uspořádala, zejména mezinárodnímu semináŕi „Securities Market Development Workshop“ v květnu r. 1996 a jeho významu pro připravované reformy kapitálového trhu v ČR (9.3.3) Ve čtvrté části subkapitoly je pojednáno o publikacích CMI, po níž je zařazen podrobný Exkurz o obsahu vydaných publikací (9.3.4).

\subsubsection{Vybrané údaje o CMI}

Společnost CMI - Institut pro kapitálový trh, spol. s r.o. (IČ 62583336), sídlem Praha 6, Na Dyrince 12, byla založena dne 1. prosince 1994. Anglický název společnosti: CMI - Capital Market Institute. Návrh zakladatelů na doplnění názvu na CMI - Capital Market Institute Prague rejstř́k kový soud v Praze neschválil, přestože by uvedení sídla společnosti v Praze v jejím názvu bylo přispělo k lepší identifikaci společnosti pro zahraniční zájemce o její služby. Podle tehdy platného živnostenského zákona byly do obchodního rejstř́ku zapsány tyto činnosti: činnost organizačních a ekonomických poradců, školící činnost v oblasti ekonomiky a vydavatelská činnost

Společnost CMI byla založena z podnětu Ministerstva financí ČR, které požadovalo, aby činnosti nové společnosti byly odděleny od činností společnosti IPRFT (viz výše 9.1), 
specializované na provádění školení maklérù podle smlouvy mezi MFČR a IPRFT. Hlavním důvodem byla nutnost oddělit školení makléřủ účetně od jiných akcí, které IPRFT v letech 1992-1994 uskutečnil ve spolupráci s jinými organizacemi, tj. zabezpečit - v zájmu obou institucí - finanční transparentnost školení makléřu.

Fakticky společnost CMI od začátku roku 1995 fungovala jako paralelní společnost společnosti IPRFT, založené r. 1992. Její činnost byla orientována na vydávání publikací v ediční řadě označené jako „Dokumenty“, které byly věnovány různým aktuálním otázkám (viz dále 9.3.4).

\subsubsection{Mezinárodní zapojení CMI}

Společnost CMI se na základě iniciativy tehdejšího generálního tajemníka Federace evropských burz (FESE) Jean-Pierre Paelincka v r. 1995 stala řádným členem mezinárodní organizace European Capital Market Institute (ECMI), tehdy se sídlem v Madridu. Tento evropský institut sdružoval 200 institucí a organizací činných na kapitálových trzích členských zemí EU, a to jak bank a obchodníků s cennými papíry, tak řady univerzit a výzkumných pracovišt' zabývajících se problematikou kapitálového trhu.

ECMI v 90. letech každoročně pro své členy pořádal seminář s aktuální tematikou kapitálových trhů, na nichž jsou prezentovány výsledky výzkumů.

Členský př́íspěvek v ECMI tehdy činil 1000 ECU, pro univerzity 250 ECU. ECMI přiznal soukromé společnosti výjimečně status univerzity na dobu členství od r. 1995 do r. 1998, s tím, že tento zvláštní status může být prodloužen. K tomu již nedošlo, protože po r. 1999 byla činnost CMI utlumena.

Po dobu členství se zástupci CMI účastnili řady akcí ECMI. V r. 1998 CMI předložil ECMI iniciativní návrh na vypracování analytické studie o kapitálových trzích v postsocialistických zemích. Tento návrh nebyl přijat, nebot’ tehdy v ECMI z uvedené skupiny zemí byl CMI jediným řádným členem.

CMI v letech 1995-1998 udržoval kontakty (vesměs na osobní bázi) s většinou evropských burz, s FESE v Bruselu, se Světovou federací burz (WFE) v Paříži, s americkou Komisí pro cenné papíry (SEC), s burzami v New Yorku a v Chicagu aj. Většina těchto institucí a organizací zasílala na adresu CMI nevyžádané i vyžádané informace, pozvání na různé akce, i různé odborné publikace.

CMI udržoval kontakt rovněž s Georgetown University ve Washingtonu. Zástupce CMI se v r. 1998 a v r. 1999 aktivně zúčastnil konference o kapitálových trzích uspořádané tamní fakultou

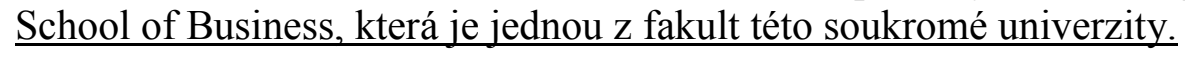

\subsubsection{Konference a semináře CMI}

CMI ve spolupráci s EDI (Economic Development Institute of the World Bank) ve dnech 2223. května 1996 uspořádal mezinárodní seminář k otázkám kapitálového trhu. Této akce se zúčastnila řada zahraničních odborníků spolu se zástupci nejvýznamnějších českých institucí a organizací činných na českém kapitálovém trhu.

Semináŕ zahájil úvodním slovem místopředseda vlády České republiky JUDr. Jan Kalvoda. První referát, který v prvním dni dvoudenní konference přednesli (ve dvou samostatných 
částech) Joseph E. Pegues (EDI) a Demir Yener (EDI), byl věnován globálním problémům vývoje finančních a kapitálových trhů ve světě. Další referát o globálních trzích přednesl G. Kleiman (Kleiman International Consultation Inc., Washington). Jednání konference pokračovalo referátem doc. Ing. Vladislava Pavláta, CSc. (CMI, BCPP) o českém kapitálovém trhu a jeho současných problémech. První den konference byl zakončen obsáhlým referátem, který přednesl Barry Bird (International Securities Consultants, Londýn), analyzoval celou řadu diskusních problémů souvisících se vznikem kapitálového trhu v ČR. Zdůraznil v něm význam důvěry, spolehlivosti a dobré pověsti obchodníků s cennými papíry. Druhý den seminár pokračoval jednáním o právních a institucionálních otázkách. Referát přednesla Claudia Morgenstern (IFC Washington). Poté následovala diskuse v sekcích, jejímž cílem bylo vypracovat návrhy a doporučení, týkající se nejnaléhavějších změn na českém kapitálovém trhu. Během odpoledního jednání proběhla plenární diskuse o těchto návrzích. V závěru semináře bylo odhlasováno vypracované doporučení. (Podrobnější obsah jednání semináře byl uveřejněn v časopise ABK, č. 6, 1996, str. 12-13. V časopise ABK rovněž byly uveřejněny i některé další příspěvky účastníků semináře - viz dále.)

Tab. 7

Složení účastníků semináře podle typu organizace/instituce

\begin{tabular}{|l|c|c|c|}
\hline Účastníci & $\check{C} R$ & $S R$ & Ostatni \\
\hline Banky & 6 & 4 & 2 \\
Obchodníci s CP & 7 & 6 & 1 \\
Burzy & 8 & 6 & 2 \\
Pojištovny & 1 & 1 & - \\
Asociace & 6 & 4 & 2 \\
ČNB & 3 & 3 & - \\
RM - S & 2 & 2 & - \\
CMI & 4 & 4 & - \\
US - AID & - & - & 1 \\
Nefinanční sféra & 4 & 4 & - \\
Celkem 42 & & & \\
(100\%) & & & \\
\hline
\end{tabular}

Zdroj: vlastní zpracování

Semináře se zúčastnilo 24 zahraničních účastníků, z nich ze Slovenské republiky 18. Většinu účastníků tvořili představitelé vrcholového vedení zúčastněných organizací (celkem 37 osob).

Účast místopředsedy vlády ČR Jana Kalvody a řady vlivných reprezentantů řady institucí (včetně účasti předsedy Burzovní komory BCPP Ing. Tomáše Ježka) na semináři, ze kterého vzešla - v př́tomnosti amerických a britských finančních odborníků - důležitá doporučení naléhavých změn na českém kapitálovém trhu, výrazně podpořila vyjednávací pozici většiny zástupců organizací českého kapitálového trhu. 
Blok 12

Doporučení k rozvoji českého kapitálového trhu, přijatá účastníky mezinárodního semináře konaného ve dnech 22-23. května 1996 ve spolupráci EDI a CMI v Praze Úplný text doporučení

1. Usilovat o vytvoření předpokladů pro vznik nezávislého regulátora trhu (např. Komise pro cenné papíry a burzu), který bude vybaven adekvátní pravomocí při regulování českého kapitálového trhu a který zároveň bude vybaven legislativní pravomocí.

2. Posílit prvky samoregulace na straně všech účastníků českého kapitálového trhu.

3. V současné právní úpravě týkající se kapitálového trhu zajistit zpřesnění pojmu (a) obchodník s cennými papíry, (b) obchodování s cennými papíry, a to vzhledem $\mathrm{k}$ tomu, že př́slušná ustanovení zákona o cenných papírech plně neodpovídají zájmům českého kapitálového trhu.

4. Zajistit novelizaci účetních a daňových předpisů týkajících se obchodování cennými papíry a dalších transakcí uskutečňovaných na kapitálovém trhu.

5. Zabezpečit novou legislativní úpravu postavení Střediska cenných papírů, která by umožňovala eliminovat převody obchodního charakteru (u právnických osob), a která by rovněž umožnila účastníkům kapitálového trhu podílet se na regulaci činnosti SCP, po př́p. se v budoucnu i majetkově účastnit na činnosti SCP. Takto bude možno postupně vytvářet předpoklady pro racionální architekturu kapitálového trhu spojenou s úsporou transakčních nákladů.

6. Středisko cenných papírů transformovat tak, aby především plnilo funkce spojené $\mathrm{s}$ fungováním kapitálového trhu (tj. funkci centrálního depozitáře) a nikoliv funkce daňové.

7. Usilovat o výrazné zvýšení transparentnosti českého kapitálového trhu zejména tím, že Středisku cenných papírů a př́isl. sub-registrům bude uloženo uveřejňovat v reálném čase důležité informace o obchodech a převodech cenných papírů v rozsahu, který bude odpovídat standardním zvyklostem v zahraničí.

8. Usilovat o přesné stanovení postupů a povinnosti při zveřejňování informací o emisích a emitentech cenných papírů, zařazených $\mathrm{k}$ obchodování na veřejných trzích, včetně př́ísnějších sankcí za příp. neplnění těchto povinností.

9. Uskutečnit přeměnu Burzovního registru cenných papírů tak, aby plnil funkci „global nominee“ pro účastníky trhu. Takto bude umožněno, aby Burzovní registr prováděl dodání cenných papírů proti zaplacení podle Doporučení G 30 a zajišstoval rovněž tzv. „stock events".

10. Zajistit, aby byly jasněji definovány povinnosti obchodníka s cennými papíry ve vztahu k operacím s penězi nejasného původu; a to tak, aby obchodník s cennými papíry měl pouze oznamovací povinnost bez odkladného účinku na jeho transakce.

Pramen: Text „Doporučení“ je citován podle znění uveřejněného v časopise ABK č. 7/1996, s. 12.

Výsledky jednání mezinárodního semináře byly publikovány v českém tisku, např. v anglické př́loze odborného měsíčníku ABK, v týdeníku Ekonom a v denním tisku.

Mezinárodní seminář CMI/EDI bezprostř̌edně předcházel jednání v Kolodějích, kde za účasti předsedy vlády bylo MFČR přinuceno přislíbit realizaci řady změn na českém kapitálovém trhu, kterým se do té doby houževnatě bránilo. 
V r. 1997 CMI uspořádal na zakázku organizace World Learning (jako vítěz veřejné soutěže) dvoutýdenní seminář o problematice kapitálového trhu pro skupinu odborníků a vedoucích hospodářských pracovníků z republiky Bosna a Hercegovina v Praze.

V r. 1998 CMI zvítězil v další veřejné soutěži organizované toutéž americkou organizací a byl pověřen uspořádáním dalšího semináře, tentokrát k problematice depozitářů cenných papírů, opět pro účastníky z republiky Bosna a Hercegovina.

\subsubsection{Publikace CMI}

V letech 1995-97 byl CMI spoluvydavatelem měsíčníku Akcie - Burza - Kapitál (ABK), který vycházel ve vydavatelství Magnet-Press v Praze.

CMI uveřejnil v edici interních publikací „Dokumenty“ tyto publikace a/nebo expertízy:

- Pavlát, V. „,The Creation and Development of the Capital Market in the Czech Republic 1990-1994“( (červen 1995)

- „Úvod do teorie derivátů a uplatnění derivátů v praxi“ (1997)

- „Úvod do teorie derivátů a jejich aplikace“ (únor 1997)

- „Pracovní podklady pro př́ípravu na makléřskou zkoušku“ (září 1997)

- „Uloga investicionih fondova i privatizaciji“ (srpen 1997)

V r. 1994 kromě toho CMI vydal společně s vydavatelstvím Magnet-Press knižní publikaci „Kapitálový trh v České republice - The Capital Market in the Czech Republic - 1993-1994“ (souběžně v češtině a angličtině).

\section{Exkurz 6}

\section{Ediční činnost CMI}

Tento exkurz obsahuje podrobnější údaje o ediční činnosti CMI. Jde o vybrané údaje o obsahu vydaných publikací, jejich účelu a využití ve výukových kurzech. U některých publikací byly v zájmu autenticity uvedeny citace částí výkladu; u pramenů, označených jako expertízy, jsou rovněž uváděny některé důležité citace z uveřejněných doporučení, které podtrhují význam těchto návrhů. Exkurz 4 obsahuje informace celkem o pěti vydaných publikacích.

1. Vladislav Pavlát: „The Creation and Development of the Capital Market in the Czech Republic 1990-1994“(červen 1995; 45 stran)

Tato studie byla původně vypracována $\mathrm{v}$ anglickém znění na základě výzvy amerického Institutu pro ekonomický rozvoj při Světové bance (EDI) pro seminář, který EDI uspořádala ve dnech 19-22. února 1995 ve Fontainebleau ve Francii pro skupinu vybraných odborníků pro otázky finančního trhu $\mathrm{z}$ afrických a evropských zemí. V edici EDI byla vydána v publikaci „Securities Market Development. A Guide for Policy Makers“ jako jedna z šesti tzv. Country Studies (př́padových studií).

CMI uvedenou studii $\mathrm{v}$ upraveném znění publikoval $\mathrm{v}$ červnu 1995; IPRFT ji uváděl v literatuře vybraných výukových kurzů. 
Obsah publikace: 1. Important information about the Czech Republic and its economic development; 2. History of the creation of a capital market in the CR; 3. Legislation; 4. Structure of capital market institutions; 5. Organization and function of the secondary capital market; 6. Taxation; 7. Selected facts about capital markets in the CR. 8. Current problems. 9. Conclusion.

Účelem studie bylo popsat vznik a rozvoj kapitálového trhu v ČR v letech 1990-1995, osvětlit klady a zápory procesu vzniku českého kapitálového trhu a připravit podklady pro úvahy o praktických krocích při vzniku a rozvoji kapitálových trhů vznikajících v jiných zemích (emerging markets).

2. Úvod do teorie derivátů a uplatnění derivátů v praxi. Speciální kurz pro pracovníky BCPP $(1997 ; 22$ stran $)$

Publikace byla určena účastníkům speciálního týdenního kurzu (v celkovém rozsahu 40 hodin výuky), určeného pro vybrané pracovníky BCPP. Obsah publikace: 1. Časový rozvrh kurzu; 2. Osnovy speciálního kurzu; 3. Kontrolní otázky; 4. Doporučená literatura; 5. Ilustrační materiály. 6. Lektoři. Denní program trval od 8.30 do 17.30, s hodinovou polední přestávkou na oběd. Kurz se konal v budově vydavatelství Magnet-Press, Jungmannova 26. Po ukončení kurzu se $\mathrm{v}$ předem ohlášených termínech konala zkouška. Úspěšným účastníkům kurzu bylo vystaveno osvědčení o absolvování kurzu.

Osnovy kurzu obsahovaly tyto části: 1 . Úvod do teorie derivátů a uplatnění derivátů v praxi. Pojem, funkce a význam derivátů; 2. Termínové a opční burzy; 3. Nestandardizované termínové kontrakty (forwardy); 4. Standardizované termínové kontrakty (futures); 5. Swapy; 6. Teorie oceňování opcí; 7. Základní postupy při oceňování opcí; 8. Anglická terminologie a anglo-americká realita. Tuto osnovu IPRFT předložil BCPP i prŕslušnému útvaru MFČR k posouzení. Program kurzu byl schválen; v diskusi bylo konstatováno, že obsah kurzu odpovídá aktuálním potřebám BCPP a reálné úrovni znalostí pracovníkủ burzy v této oblasti; kurz umožnil, aby se burza připravovala na prŕpadné zahájení obchodů $\mathrm{s}$ deriváty $\mathrm{v}$ předstihu před jinými subjekty.

Účastníci kurzu měli k dispozici celkem 69 otázek, pokrývající celou problematiku. Byly zpracovány v souladu s obsahem přednášek i s doporučenou literaturou. Součástí publikace byly ilustrační materiály (ukázky statistik, přehled úrokových bází, příklad křížových kurzů měn a futures, základní údaje o nejdůležitějších derivátových indexech, př́klad výpočtů opcí na index a príklady zakázaných praktik obchodování na burzách futures aj.), které byly navázány na přednášky.

Kurz odpřednášeli tito přednášející: doc. Ing. Vladislav Pavlát, CSc. (přednášky č. 1, 2 a 3); doc. RNDr. Přemysl Záškodný, CSc. (přednášky č. 4-7) a Ing. Oldřich Zíka (přednáška č. 8).

3. Úvod do teorie derivátů a jejich aplikace. Speciální kurz pro pracovníky BCPP - Výběr dokumentů (únor 1997; 12 stran)

Publikace obsahovala text o regulaci burzovních obchodů $\mathrm{s}$ deriváty v USA a 4 př́klady různých smluv v angličtině převzatých z pramenů derivátové burzy v Chicagu. Publikace 
byla určena jako pomocný materiál k výuce anglické terminologie, vztahující se

k finančním derivátům ( $v$ přednášce č. 8.)

4. Pracovní podklady pro přípravu na makléřskou zkoušku (záŕí 1997; 48 stran)

Tato publikace byla vydána pro účastníky kurzu (označovaného názvem „Nové repetitorium“) a sloužila uchazečům o makléřskou zkoušku jako sbírka různých prŕíkladů pro opakování látky, předepsané ke zkoušce. Obsahovala různá schémata znázorňující vztahy na finančních trzích, úlohu finančních zprostředkovatelů, typologii akcií, druhy burzovních ukazatelů, př́klady z technické analýzy a z finanční aritmetiky. Publikace navazovala na čtyřdílnou úspěšnou publikaci IPRFT „Makléřské minimum“, která poprvé vyšla v r. 1993.

5. Úloha investičních fondů a privatizace (,Uloga investicionih fondova i privatizaciji“, srpen 1997)

Publikace byla vydána jako doplňkový materiál ke školení pracovníků finančních institucí z republiky Bosna a Hercegovina ve dnech 2.-15. srpna 1997 v Praze.

Publikace obsahovala časový program kurzu, přehled obsahu hlavních přednášek a seminářů, otázky dvou panelových diskusí na téma „Perspektivní kolektivní investování v České republice a v jiných zemích východní Evropy“ a jmenný seznam 11 přednášejících. Do programu bylo zařazeno celkem 9 přednášek. Součástí programu dále byly 2 semináře: „Potenciální úloha fondů v republice Bosna a Hercegovina“ a „Hodnocení a výpočet efektivnosti investičního fondu“. Během kurzu jeho účastníci absolvovali exkurze na Burzu cenných papírů, UNIVYC, Středisko cenných papírů (SCP) a také RM-S, v jejichž průběhu se seznámili s provozem těchto institucí.

Lektorský sbor byl sestaven z odborníků 6 institucí: IPRFT/CMI (doc. Ing. Vladislav Pavlát, CSc., doc. RNDr. Přemysl Záškodný, CSc., doc. JUDr. Jarmila Pavlátová, CSc., Ing. Oldřich Zíka), MFČR (doc. Ing. Antonín Kubíček, CSc., Ing. Marie Ježková, Ing. Dušan Libnar); BCPP (JUDr. Ing. Václav Školout); Fakulta společenských věd UK (doc. Ing. Michal Mejstř́ík, CSc.); Unie investičních fondů ČR (Ing. Václav Liška); EURO ASSET MANAGEMENT (Ing. Jiří Vašek).

Program kurzu zahrnoval 7 tematických oblastí: 1 . Investiční fondy I. (finanční trhy a jejich úloha; struktura finančního trhu; nástroje finančního trhu; nástroje kapitálového trhu; kolektivní investování a jeho úloha.); 2. Investiční fondy II. (instrumentarium fondů kolektivního investování; právní formy kolektivního investování; typy investičních fondů; ekonomika, organizace a řízení fondů; investiční fondy v ČR); 3. Operace investičních fondů (teorie portfolia, rozbor portfolia; model CAPM a APT; ř́zení portfolia v praxi fondů); 4. Právní předpisy regulující fungování investičních fondů (význam právních předpisů týkajících se fondů kolektivního investování; právní předpisy v ČR; hlavní nedostatky právních předpisů ve světle praxe a cesta $\mathrm{k}$ jejich odstranění; 5 . Regulace kapitálových trhů (obecně o regulaci; systémy regulace; mechanismus regulace a dozoru na kapitálový trh v ČR; očekávané změny v systému regulace kapitálového trhu ČR); 6. Resumé; 7. Shromažd'ování a šíření informací o investičních fondech (obecně o informační povinnosti; obecně závazné předpisy v ČR; předpisy BCPP; aktuální problémy).

Obsahovou i organizační úroveň kurzu jeho účastníci zhodnotili velmi pozitivně. 


\section{Shrnutí}

Př́nos činnosti společnosti CMI, paralelně s IPRFT, pro vývoj českého kapitálového trhu a jeho dílčí reformu spočíval jak $\mathrm{v}$ její angažovanosti $\mathrm{v}$ mezinárodním měřítku (zejména $\mathrm{v}$ jejím aktivním členství v ECMI), tak v podpoře vzdělávacích aktivit IPRFT a jeho publikační činnosti. I když $\mathrm{v}$ počátečních fázích formování československého a později českého finančního trhu rozsah činnosti jednotlivých zainteresovaných osob a/nebo firem nebyl prŕliš velký, přesto sehrál - hlavně před založením BCPP - pozitivní úlohu v tom, že opakovaně připomínal nutnost vzniku kapitálového trhu a burzy pro přechod k tržní ekonomice.

Obě př́padové studie jsou důkazem toho, že počáteční soukromé iniciativy přinesly pozitivní výsledky zejména tím, že se jednotlivci nebo některé firmy spojily se státními orgány na úrovni ministerstev za účelem realizace kroků podporujících přechod $\mathrm{k}$ tržní ekonomice ve finanční sféře.

IPRFT vyvinul během činnosti v letech 1991-1998 mimořádné úsilí, s cílem co nejvíce přispět k rozvoji českého kapitálového trhu, odpovídajícího standardům evropské finanční sféry. Tento cíl byl programově orientován na podporu takové obsahové náplně finančních znalostí dospělého obyvatelstva činného ve vznikající finanční sféře národního hospodářství ČR, které by odpovídaly mezinárodním zvyklostem a kultuře ve vyspělých západoevropských zemích. Mezi ně se ČR hodlala co nejdř́ve zařadit: v r. 1995 vstoupila do OECD.

Tento záměr vycházel z nutnosti aplikace mezinárodních principů podnikání na kapitálových trzích, což znamenalo: co nejvíce se přiblížit k obsahu vznikajícího českého zákonodárství v oblasti kapitálového trhu (včetně zabezpečení standardního postavení burzy cenných papírů), požadavek respektu a úcty k platným zákonům finanční sféry a jejich přibližování k obsahu a úrovni mezinárodně uznávaných standardů, podpory úsilí o vznik odpovídajících institucí finanční sféry, zejména Komise pro cenné papíry jako vrcholného orgánu dozoru na finanční trh, snahy o zvyšování nároků na všechny účastníky kapitálového trhu, směřující ke zvýšení potřebné úrovně transparentnosti jejich činnosti, požadavek zvyšování odborné kvalifikace pracovníků finanční sféry a k dodržování deklarovaných etických zásad podnikání na kapitálovém trhu.

Tyto zásady se IPRFT (a od r. 1995 společně s paralelní společností CMI) v míře odpovídající jejich omezeným finančním a kapacitním možnostem poskytování osvětových vzdělávacích a informačních služeb snažil realizovat. Lze konstatovat, že během své činnosti se tyto zásady obě uvedené společnosti snažily důsledně dodržovat, i když leckdy ve svůj neprospěch. Za významné a úspěšné lze považovat napřr. úsilí IPRFT upozorňovat na vysoká rizika spojená s předčasným zavedením obchodování $\mathrm{s}$ finančními deriváty na veřejných trzích, které by $\mathrm{v}$ tehdejších chaotických poměrech pravděpodobně mělo velmi negativní dopady (včetně měnových).

Neveřejné publikace obou společností (IPRFT a CMI) byly ze strany př́ijemců vysoce hodnoceny, nebot' jim ve stručné podobě přibližovaly obsah a smysl sporných stanovisek různých zainteresovaných stran (včetně různých doporučení a návrhů změn), a také doplňovaly znalost mezinárodních standardů a stanovisek mezinárodních organizací.

Většina uspořádaných přednáškových kurzů měla velmi kladnou odezvu u posluchačů. Většina kurzů měla základní úroveň obtížnosti (tzv. basic), část měla střední úroveň obtížnosti (tzv. intermediate). Způsob výuky odpovídal vysokoškolské úrovni. Kurzy prokazatelně sehrály mimořádně pozitivní úlohu při formování finančního vzdělání pracovníkủ finanční sféry v ČR. 


\section{Výsledky zkoumání}

Výsledky autorova bádání jsou shrnuty v této samostatné kapitole, která hodnotí př́ínos dílčích poznatků, uvedených $\mathrm{v}$ jednotlivých částech této publikace, pro celkový rozvoj mimoškolního finančního vzdělávání dospělých v jednotlivých fázích vývoje českého kapitálového trhu.

\section{I.}

Publikace „Finanční vzdělávání dospělých a jeho úroveň v ČR v90. letech“ byla zpracována jako „odborná kniha“, odpovídající definici druhu výsledků podle usnesení vlády ČR ze dne 29. 11.2017 č. 837.

Účelem publikace a jejím posláním je vyplnit mezeru existující v odborné literatuře věnované zkoumání počátků finančního vzdělávání a úrovně finančního vzdělání dospělých v souvislosti $\mathrm{s}$ vývojem českého kapitálového trhu, zkoumat hybné síly tohoto procesu a přispět $\mathrm{k}$ jeho objektivnímu hodnocení.

Většina prací českých autorů, týkajících se zkoumání vývoje českého trhu cenných papírů v 90. letech, se tehdy zabývala především zkoumáním relevantních otázek vývoje tohoto trhu $\mathrm{s}$ částečným přihlédnutím $\mathrm{k}$ obecným teoretickým poznatkưm o finančních trzích. Potřeby finančního vzdělávání v té době víceméně zůstávaly na okraji zájmu; kontext mezi vývojem reálného trhu cenných papírů a finančním vzděláváním fakticky nebyl zkoumán.

Koncepce výzkumu, jehož výsledky jsou zde stručně charakterizovány - na rozdíl od dř́vějších př́stupů - naopak vycházela z předpokladu, že úspěšnost vznikajícího českého trhu cenných papírů (jinými slovy řečeno - finančního trhu, zahrnujícího kapitálový trh) do značné míry závisí na tom, zda - a jak rychle - si účastníci tohoto trhu osvojí potřebné či alespoň základní odborné znalosti této oblasti. Proto byl předmět zkoumání v předložené publikaci definován jako vývoj finančního vzdělávání a jeho úrovně ${ }^{42}$ v ČR v období let 1990-1997 v souvislosti s konstituováním českého kapitálového trhu.

$\mathrm{V}$ původní koncepci předloženého výzkumu se počítalo $\mathrm{s}$ jeho širším pojetím $\mathrm{s}$ tím, že zkoumání zahrne vývoj institucionální struktury českého trhu cenných papírů, prèehled o obsahu a formách školského i mimoškolního finančního vzdělávání a event. i právní problematiku. $\mathrm{V}$ důsledku toho bylo nutno předmět zkoumání omezit a zaměřit jej prioritně na mimoškolní finanční vzdělávání dospělého obyvatelstva České republiky.

Publikace byla $-\mathrm{s}$ přihlédnutím $\mathrm{k}$ těmto omezením - nakonec koncipována jako př́íspěvek $\mathrm{z}$ aplikované ekonomie, vycházející z poznatků ekonomické teorie tam, kde je to z hlediska výkladu vhodné a nutné.

Není tedy odbornou knihou z oboru historie ani z pedagogiky, resp. andragogiky, s nimiž se však v mnoha směrech stýká a jejichž poznatků místy využívá.

\footnotetext{
${ }^{42}$ V odborné literatuře v ČR v 90. letech pojem „,finanční gramotnost“, již tehdy obvyklý v anglo-americké terminologii, minimálně do poloviny 90 . let ještě nebyl běžně používán. Běžně se používal termín „finanční vzdělávání“ a „úroveň finančního vzdělávání“.
} 
Obsahově lze tuto knihu zařadit do oboru aplikované ekonomie podle klasifikace JEL takto: A2. Economic Education and Theory of Economics: A29 (other); B2. History of Economic Thought since 1925: B29 (other); I. Health, Education and Welfare: I22 Educational Finance.

Publikace se nezabývá právní problematikou. Citace právních předpisů většinou slouží jako př́klady. $Z$ archivních dokumentů ústředních úřadů státní správy byly do rozborů zařazeny pouze dokumenty př́stupné veřejnosti. Zkoumání situace $\mathrm{v}$ oblasti vybavenosti veřejných knihoven finanční literaturou nebylo součástí zadání; je však nasnadě, že i tato skutečnost měla význam mj. na kvalitu původní české akademické literatury. Knižní trh byl záhy přehlcen překladovou zahraniční literaturou, v řadě př́ípadu nepř́liš významného obsahu. Vzhledem $\mathrm{k}$ omezenému rozsahu této publikace musel být rozsah prŕloh omezen; do části kap. 7 a 8 této publikace mohly být $\mathrm{v}$ důsledku omezení rozsahu zařazeny pouze nejdůležitější informace.

Před výkladem specifických otázek spojených s vývojem finanční edukace a její úrovně byla předřazena kap. 3 obsahující výklad základních pojmů, jejichž znalost je nezbytná pro pochopení výsledků navazujícího rozboru specifických problémů transmise zahraničních poznatků (learning transfer) do podmínek v ČR, spojené s rozborem hlavních překážek znesnadňujících edukační proces v ČR. Tento postup byl užitečný v tom, že umožnil stručně poukázat na značné názorové rozdíly mezi zahraničními odborníky $\mathrm{v}$ obecném pojetí edukačního procesu a chápání finančního vzdělávání zúženého $\mathrm{v}$ podstatě na zásady, umožňující racionální chování dospělých občanů při jejich finančním rozhodování.

\section{II.}

Nicméně ani výše uvedená omezení předmětu zkoumání v odst. I. nemění nic na skutečnosti, tato kniha je prvni publikací v české finančni literatuře, která zkoumá vzájemné interakce mezi vývojem reálného trhu cenných papirů (včetně prvků jeho nadstavby) a vývojem finančního vzdělávání a finanční gramotnosti v 90 . letech minulého století.

Na základě poznatků ekonomické teorie byly formulovány hlavní rysy vzájemných souvislostí obou zkoumaných procesů.

1. Mezi vývojem reálné ekonomiky (včetně její finanční sféry) a vývojem finančního vzdělávání existuje silná zpětná vazba: každý významnější krok kupředu v reálné ekonomice (a ve finanční sfére) se odráží $\mathrm{v}$ oblasti finančního vzdělávání a představuje potřebu (poptávku) po odpovídajícím dalším kroku ve finančním vzdělávání. Analogicky další pokrok v oblasti finančního vzdělávaní se zpětně (potenciálně) promítá do reálné ekonomiky (finanční sféry) a představuje odpověd' finanční vzdělávací soustavy na signál potřeby (poptávky), vyslané reálnou ekonomikou.

2. Tyto vztahy platí obecně, avšak v konkrétních podmínkách místa a času bývají modifikovány např. vývojem konjunkturního cyklu, nerovnovážným vývojem nabídky a poptávky, i jinými mimořádnými událostmi (př́rodní vlivy, změny režimu, války). V ČR byly modifikace obecně přijímaného standardního vývoje vztahů výše uvedených sub. 1 vyvolány prioritou politických rozhodnutí týkajících se restituce znárodněného majetku, prosazení kuponové privatizace jako hlavní metody privatizace státního vlastnictví a př́liš liberálního pojetí transformačních procesů bez dostatečně propracované legislativy a bez nezbytné regulace ekonomických procesů. 
Z povahy výše uvedených teoretických souvislostí lze vyvodit také některé praktické závěry:

1. Objektivní zkoumání vývoje finančního vzdělávání může být účelné a př́ínosné pouze při respektování zpětné vazby mezi finančním vzděláváním a reálnou ekonomikou (finanční sférou). Proto jsou v této publikaci při rozboru finančního vzdělávání v různých etapách jeho vývoje vždy stručně charakterizovány důležité události ve finanční oblasti, které mohly být příčinou změn $\mathrm{v}$ obsahové náplni finančního vzdělávání, $\mathrm{v}$ použití nových technických pomůcek, ve způsobu výkladu aj.

2. Princip zpětné vazby při analýzách finančního vzdělávání a měření úrovně znalostí (finanční gramotnosti) lze považovat za paradigma, jehož respektování je zárukou objektivity zkoumání a dosažených výsledků.

\section{III.}

Za přínos dané knihy lze označit uplatnění nové periodizace zkoumaného období, která lépe vystihuje zvláštnosti jednotlivých etap vývoje českého kapitálového trhu a vývoje finančního vzdělávání jako zpětné vazby. Určujícím faktorem pro změny obsahu i forem finančního vzdělávání ve sledovaném období byly události na rodícím se kapitálovém trhu. (Nová periodizace se liší od periodizace publikované ve starších autorových pracích.)

Základním členěním je rozlišení tř́ základních období zkoumaného vývoje:

1. etapa $=1990-6$. duben 1993

2. etapa $=1993($ od 6. 4.) -1994

3. etapa $=1995-1997$ (počátek reformních kroků)

Jednotlivé etapy se navzájem odlišují svým specifickým charakterem, který jim vtiskly hlavní události na kapitálovém trhu a hlavní události v oblasti finančního vzdělávání a v oblasti regulace obou procesů. Události v oblasti státní regulace prolínají oběma procesy.

Při hodnocení vývoje finančního vzdělávání v ČR v letech 1990-1997 lze poukázat na tato specifika jednotlivých etap:

V prvním základním období rozvoje českého kapitálového trhu (1990-1992) tehdejší garnitura politiků nepovažovala otázku finančního vzdělávání za prioritní. Přesto však již v tomto období na základě soukromých iniciativ a po založení tzv. Přípravného výboru i díky jeho činnosti byly položeny základy mimoškolního finančního vzdělávání dospělého obyvatelstva.

V druhém základním období (1993-1994) započala praktická realizace základního finančního vzděláváni pracovníkủ činných v oblasti českého kapitálového trhu díky aktivitám ČNB, MFČR, $B C P P$ (zejména školení makléřü; rozvoj informační a osvětové činnosti pro veřejnost $\mathrm{v}$ tisku, rozhlasu a televizi).

Třetí základní období formování českého kapitálového trhu a soustavy finančního vzdělávání je obdobím počátků dílčích reforem českého kapitálového trhu. Cílem těchto dílčích reforem bylo jednak odstranění dílčích nedostatků a nešvarů v tehdejší praxi účastníků kapitálového trhu, jednak snaha o přizpůsobení českého kapitálového trhu a chování jeho účastníků směrem k uznávání a praktické aplikaci standardů evropských kapitálových trhů. 
V oblasti finančního vzdělávání dospělých lze v tomto období pozorovat další pokrok v tom, že na stránkách tisku i v ostatních médiích se množily kritické pohledy na nevyhovující stav. Kvalita většiny uveřejňovaných př́íspěvků, znalost terminologie i argumentační vyzrálost byla vyšší než v předchozích letech.

IV.

Jednou z velmi důležitých otázek, zkoumaných $\mathrm{v}$ této publikaci, byl rozbor bariér stojicích $v$ cestě $k$ preméně českého nestandardního kapitálového trhu ke stabilnímu, standardnímu trhu a vliv těchto přkéážek na rozvoj finančního vzdělávání a na jeho úroveň.

Při zkoumání těchto otázek bylo zjištěno, že přenosu zahraničních poznatků do kulturního prostředí v ČR (v zahraniční literatuře označovaný též jako tzv. learning transfer) nejvíce bránily 4 hlavní druhy překážek:

(a) nedostatečné jazykové znalosti potenciálních účastníků nabízených kurzů,

(b) nerozvinutost české finanční sféry; účastníci vzdělávacích kurzů však měli dostat příležitost, aby se teoreticky i prakticky seznamovali s finančními produkty, s procedurami a institucemi, z nichž mnohé na vznikajícím českém kapitálovém trhu tehdy ještě neexistovaly, ale jejichž budoucí existence se předpokládala,

(c) nedostatečný rozvoj a nejednotnost české terminologie při překládání zahraničních nástrojů kapitálového trhu do českého jazyka,

(d) technické překážky bránicí transferu finančních poznatků.

Zároveň se dospělo k poznání, že transfer finančních poznatků může být efektivní v oblasti poradenské a expertní činnosti.

S předchozím problémem bezprostředně souvisí otázka, zda a do jaké míry finanční vzdělávání ve sledovaném obdobi korespondovalo potřebám rozvoje kapitálového trhu v České republice a jak prispívalo k řešení jeho problémů. Dále bylo zkoumáno, zda a jak se během zkoumaného obdobi úroven finančního vzděláváni dospělých přibližovala úrovni finanční gramotnosti $v$ zemich Evropské unie (viz dále).

V publikaci je rovněž hodnocen vliv zahraničních institucí na vývoj českého finančního vzdělávání.

Výsledky tohoto zkoumání umožnily vytvořit si určitou představu o tom, do jaké míry se vlády ČSFR (v prvních třech letech po r. 1989) a poté vlády České republiky (v letech 1993-1997) vypořádaly s počáteční nízkou (takřka nulovou) úrovní finanční gramotnosti.

Hlavní výsledky výzkumu lze shrnout takto:

1. Ve zkoumaném období let 1990-1997 v České republice nesporně došlo k diferencovanému zvýšení finanční gramotnosti $\mathrm{v}$ oblasti mimoškolního finančního vzdělávání dospělých.

2. Nicméně ani na konci sledovaného období se $\mathrm{v}$ dané oblasti nesnížila míra zaostávání finančních znalostí za potřbami rozvoje českého kapitálového trhu a nadále se rozevirala mezera (gap) mezi stavem průměrné úrovně finančního vzdělání v $\check{C} R$ a v evropských zemích $s$ vyspělými kapitálovými trhy. Hlavní prríčiny zaostávání nutno spatřovat v systémových vadách 
českého kapitálového trhu, způsobených absenci koncepce jeho rozvoje $i$ r̆adou chybných rozhodnutí.

3. Vlády České republiky (v letech 1993-1997) nebyly schopny se plně vypořádat s počáteční nízkou (takřkka nulovou) úrovní finanční vzdělanosti. Nedostatky v legislativě, nedostatečná dozorová činnost a nízký postih kriminality vážně ohrožovaly stabilitu ČKT; nezajišt'ovaly dostatečnou ochranu všech účastníků trhu.

\section{V.}

Institucionální struktura společnosti, jak je obecně známo, silně ovlivňuje její fungování. Od r. 1990 v české společnosti v souvislosti s přechodem k tržní ekonomice probíhaly v její institucionální struktuře významné změny. V oblasti ekonomiky postupně vznikaly nové finanční instituce spojené se vznikem finančního trhu a jeho infrastruktury. V oblasti státní správy se měnila obsahová náplň tradičně existujících vrcholových institucí - ministerstev a jiných ústředních orgánů a přibyly $\mathrm{k}$ nim také zcela nové, vesměs specializované instituce spojené s fungováním finančního sektoru (např. ministerstvo privatizace, Fond národního majetku, centrum kuponové privatizace aj.). Jejich vznik probíhal v úzké souvislosti se změnami legislativy a byl jimi právně podložen. Přechod k tržní ekonomice byl v ČR spojen s explozí soukromého podnikání prakticky ve všech oborech. Vrcholovou institucí finanční sféry a jejím symbolem (zejména vůči zahraničí) se stala Burza cenných papírů v Praze, jejíž výsadní postavení však bylo oslabeno vznikem quasi-burzy v podobě tzv. RM-S.

Tato monografie o finančním vzdělávání dospělých a jeho úrovni v 90. letech, publikovaná Vysokou školou finanční a správní v Praze v r. 2020, se při zkoumání institucionálních změn ve státní správě soustředila na činnost ministerstva financí a Státní banky československé, resp. České národní banky. Toto zkoumání jednoznačně potvrdilo, že v prvních letech po r. 1989 při prechodu k tržní ekonomice $v \check{C} R$ v oblasti centrálních orgánů státu velmi významnou, ne-li zpočátku rozhodující roli, sehrály právě tyto dvě instituce, tj. Ministerstvo financí a centrální banka.

Po určitou dobu zpočátku hlavní iniciativu v úsilí o prosazení vzniku Burzy cenných papírů ve standardním pojetí vyvinula centrální banka. Po rozdělení ČSFR na Českou republiku a Slovenskou republiku (podle výše uvedené periodizace v 2. základním období, tj. v letech 1993-1994) jednaly obě instituce v podstatě ve shodě, bez větších rozdílů v názorech a př́stupech $\mathrm{k}$ řešení základních finančních problémů transformace $\mathrm{v}$ souladu se svými kompetencemi.

Ministerstvo financí ČR využívalo své pravomoci nadřízeného orgánu vůči BCPP poměrně střídmě, avšak důrazně. Jako př́klad lze uvést nesouhlasné stanovisko MFČR k původní verzi smlouvy o pomoci Pařížské burzy při zprovoznění BCPP a složité projednávání této otázky nebo potíže při projednávání dílčích připomínek $\mathrm{k}$ burzovním předpisům.

Úloha Ministerstva financí ČR - na rozdíl od popisu činnosti MFČR ve starších pramenech je v této nové knize hodnocena kritičtěji a současně objektivněji, nebot'se zabývá jak kladnými, tak zápornými stránkami analyzované činnosti tohoto centrálního orgánu státní správy.

Nové hodnocení např. považuje za nesporný klad, že MFČR již během první základní etapy vývoje (viz výše) odmítlo opakované pokusy o založení další burzy v ČR (tzv. Opční burza) a 
že ani později (v letech 1994 a 1995) nepodlehlo tlakům na zahájení obchodování finančními deriváty na $\mathrm{BCPP}$.

Významným zjištěním je i fakt, že se MFČR v druhé etapě vývoje ČKT (viz výše) zasloužilo o zavedení systému makléřských zkoušek, že zpřísnilo udělování licencí obchodníkům s cennými papíry a že se pokusilo objektivizovat a zpřísnit i celkový proces finanční regulace (v rámci svých omezených možností). K zásluhám MFČR patří nejen snaha o zvýšení specifické vzdělanostní úrovně makléřů, ale i to, že silně podpořilo snahy soukromých subjektů o zvýšení zájmu o finanční vzdělávání u rostoucího počtu osob z řad dospělého obyvatelstva, které hodlaly přejít do finančního sektoru.

K záporům činnosti MFČR naproti tomu patřilo nadržování RM-S v otázce burzovního depozitáře cenných papírů, snaha vyloučit z veřejných diskusí kritiku RM-S a udržovat jakési „mírové soužití“ obou institucí. Za jedno z největších selhání lze považovat skutečnost, že MFČR nedokázalo zabránit schválení zákona o burzách cenných papírů, který vytvořil fikci „dvou rovnoprávných burz CP“ v ČR, ani nedostatkům v zákonu o cenných papírech, které otevřely dokořán cestu $\mathrm{k}$ nejrůznějším manipulacím a podvodům. Svou dlouhotrvající nečinností ve věci fondů kolektivního investování MFČR způsobilo vážné poruchy v tomto novém sektoru finanční sféry. Negativně nutno hodnotit také zaostávání pojišt’ovnictví a „přemnožení“ počtu obchodníků s cennými papíry.

Analýza činnosti MFČR v dané publikaci vnesla do hodnocení přččin, proč se nepodařilo odstranit řadu bariér znesnadňujících zvyšování úrovně finančního vzděláni dospělých řadu nových pohledì.

Jednou z nově hodnocených skutečností byl případ tzv. Millerovy zprávy, který je markantním příkladem kabinetní politiky MFČR a snahy nepřipustit významnější reformy obchodování na ČKT včetně odmítání a oddalování vzniku standardní Komise pro cenné papíry.

Velmi významná úloha ČNB byla zmíněna obecně již v souvislosti s novou periodizací při charakteristice jednotlivých fází vývoje ČKT a finanční edukace. V kapitole 5 byly tyto poznatky rozširréeny o popis, bližší charakteristiku a rozbor úlohy centrální banky v procesu finančního vzdělávání dospělých. Vztah ČNB je v následujícím textu doplněn o některá důležitá fakta.

Česká národní banka jakožto centrální banka (do r. 1992 SBČS) průběžně zdiorazňovala potřebu finančního vzdělání, které pro své zaměstnance zajišt'ovala v rámci samostatného útvaru. V r. 1991 podpořila uspořádání přednáškového cyklu pěti odborných seminářu pro pracovníky bank a spořitelen (březen-červen 1991) o př́ípravě založení burzy cenných papírů a o budoucím vzniku českého kapitálového trhu. Umožnila, aby této př́ležitosti bylo využito i k unikátnímu jednorázovému zjištěni úrovně finanční gramotnosti pracovníkủ bankovního sektoru.

V rámci činnosti SBČS založila a provozovala tzv. prozatímní sekundární trh, na němž se konaly aukce českých veřejně obchodovatelných obligací. Tato akce umožnila, aby se pracovníci bank několika bank mohli blíže seznámit s praxí obchodování s cennými papíry. Tato akce měla výrazný edukační náboj. 
Je doloženo, že v letech 1993-1997 se vedoucí funkcionáři ČNB aktivně zúčastňovali významnějších odborných diskusí, seminářů a národních i mezinárodních konferencí. Tato účast měla značný demonstrační efekt nejen pro pracovníky institucí bankovního sektoru, ale i pro širši veřejnost, nebot' o podobných akcích obvykle informoval i denní tisk a někdy i televize a rozhlas.

Centrální banka se sice na školním ani mimoškolním finančním vzdělávání v ČR př́mo nepodílela; svou autoritou však trvale podporovala zájem o finanční vzdělávání české veřejnosti.

Úloha BCPP v oblasti finančního vzdělávání byla odlišná než úloha obou výše uvedených centrálních orgánů ČR - Ministerstva financi a České národní banky, nebot' BCPP jako akciová společnost vzato formálně právně - se řadila mezi finanční instituce soukromé sféry, i když měla řadu specifických funkcí.

Většina českých autorů se v literatuře týkající se českého burzovnictví explicite otázkou finančního vzdělávání nezabývala; tato odborná kniha - spolu s využitím dosavadních poznatků - prináši nový pohled na činnost BCPP v edukačni oblasti spolu s jejím hodnocením.

Politika BCPP v oblasti finančního vzdělávání byla od počátku úzce spjata se šířením burzovních informací a měla pragmatický charakter, mj. díky své flexibilitě. Tiskové konference, která BCPP pravidelně pořádala, obvykle mély vzdělávací cíl, nebot' úroveň finanční gramotnosti valné části jejich účastníků byla nízká (ne-li př́ímo nulová).

Proto se BCPP při získávání potenciálních investorů rozhodla soustředit se na vysvětlování základních otázek (mezi ně např. patřilo vysvětlení, proč burzy cenných papírů vznikly, jaké jsou základní funkce burzy, s jakými cennými papíry se na burze obchoduje a jak obchodování s cennými papíry na burze probíhá, jak je organizováno vypořádání burzovních obchodů apod.). Vysvětlování složitějších otázek muselo být odloženo na pozdější dobu, až burza sama získá dostatek vlastních zkušeností.

BCPP poměrně brzy po zahájení obchodování začala vydávat vlastní tištěný informační časopis „Burza“, určený investorům i širšímu okruhu zájemců.

Vedoucí funkcionáři BCPP se ve sledovaném období let 1993-1998 aktivně účastnili různých konferencí, seminářù, př́íp. jiných akcí o českém kapitálovém trhu, pořádaných jinými organizacemi nebo institucemi, a to $\mathrm{v}$ různých formách. U některých akcí BCPP byla aktivním př́mým spolupořadatelem, u jiných byla jen účastníkem. Charakteristika těchto akcí (spolu s jejich hodnocením) je uvedena v kap. 7.

BCPP od počátku svého vzniku věnovala finančnímu vzdělávání svých zaměstnanců výjimečnou pozornost. Údaje o profesním vzdělávání zaměstnanců BCPP (vesměs dosud neuveřejněné) jsou uvedeny porůznu v subkap. $6.3 \mathrm{a}$ v kap. 4 a 8 této publikace.

BCPP se významným způsobem zasloužila o zvyšování úrovně finanční gramotnosti zejména té části dospělého obyvatelstva $\check{C} R$, která již byla zaměstnána v institucích finanční sféry nebo se do ní hodlala pracovně zapojit. 
Výše uváděné skutečnosti o specifických podmínkách vývoje finančních institucí je nutné zakončit dvěma důležitými poznámkami, aniž by bylo možno se zde meritorně zabývat rozborem uváděných nedostatků.

První z nich je poznámka k úrovni administrativní činnosti značné části centrálních institucí ČR; týká se i činnosti organizací v resortu MFČR a ČNB a v okruhu působnosti ČNB. Obecně nutno konstatovat, že v systému centrálních institucí státní správy se průměrná úroveň řízení a správy - ve srovnání s její průměrnou úrovní před r. 1989 - dosti výrazně snížila. Soudě podle údajů z oficiálních dokumentů státních institucí (různých zpráv, plánů činnosti aj.) i z údajů v denním a periodickém tisku častou př́icinou zjištěných a kritizovaných nedostatků byl nárůst resortismu a byrokratismu.

Tyto negativní jevy zčásti představovaly nedostatky systémové povahy, zčásti byly způsobeny nedokonalostmi v legislativě. Celkově však se jeví jako důsledky nedokonalých, nevhodných nebo chybných politických rozhodnutí. Nedostatky ve vymezení kompetencí některých orgánů nebo v jejich nedostatečném naplnění měly negativní dopad i ve sféře finanční edukace.

Druhá poznámka se týká funkcí BCPP: ve sledovaném období let 1993-1998 byla přeceňována funkce obchodování s cennými papíry; naproti tomu funkce emisní a alokační byla podceněna a nedošlo ani k rozvinutí dalších funkcí burz cenných papírů, známých $\mathrm{z}$ teorie a rozvinutých na burzách ve vyspělých zemích. Tato skutečnost - spolu s nedostatky, o nichž se v dané publikaci pojednává na jiných místech, se nutně - přímo nebo neprímo - promítla i v oblasti finančního vzdělávání.

\section{VI.}

Pro rozvoj finančního vzdělávání dospělých v ČR během sledovaného období let 1990-1997 nesporně sehrála média (tisk, rozhlas, televize) pozitivní roli. Tuto informační úlohu média plnila především tím, že poskytovala dospělé populaci prŕiležitost seznamovat se s událostmi ve finanční sféře (ČSFR a ČR) a s využíváním disponibilních produktů a služeb institucí činných ve finanční sféře.

Tuto úlohu média plnila diferencovaně. Podle existujících odhadů co do významu zpočátku stál na prvním místě tisk, který značně přispěl k pozitivnímu prŕstupu velké části dospělého obyvatelstva k transformaci ekonomického systému, včetně podpory kuponové privatizace.

Rostoucí úlohu zejména $\mathrm{v}$ oblasti televizního zpravodajství postupně získávala televize, zatímco vliv rozhlasu postupně slábl. Přímé osvětové a vzdělávací oblasti však televize i rozhlas věnovaly velmi omezenou pozornost. Tento vývoj byl v podstatě předurčen jednak tím, že úkoly sdělovacích prostředků byly odlišně vymezeny v rámci platných předpisů, jednak tím, že finanční vzdělávání nestálo v daném období v popředí priorit státní politiky.

Za př́nos této odborné knihy v oblasti neformálního mimoškolního finančního vzdělávání dospělého obyvatelstva lze považovat uveřejnění výsledků dílčích sondáží v oblasti odborného finančního tisku (agenda časopisu ABK v letech 1993-1996) a nejčtenějšího týdeníku Ekonom (roč. 1995). Větší část výsledků tohoto výzkumu se opírá o dosud neuveřejněné soukromé archivní prameny. Jejich uveřejnění umožňuje - mimo jiné - lépe pochopit příčiny chaotického vývoje rozdílných snah různých soukromých subjektů v oblasti vzdělávání dospělých i slabšího zájmu veřejných autorit. Na tomto místě je důležité připomenout, že oblast vzdělávání (včetně 
finančního vzdělávání) nebyla $v$ rámci kompetenčního zákona výslovně svěřena žádnému ministerstvu ani jinému centrálnímu orgánu. Retardační roli při transferu teoretických poznatků i edukační praxe do českých poměrů také sehrála i značná organizační, technická a rozpočtověfinanční omezení spolu s jazykovými bariérami.

\section{VII.}

I když v počátečních fázích formování československého a později českého finančního trhu rozsah činnosti jednotlivých zainteresovaných osob a/nebo firem nebyl př́liš velký, přesto sehrál - hlavně před založením BCPP - pozitivní úlohu v tom, že opakovaně připomínal nutnost vzniku kapitálového trhu a burzy pro přechod k tržní ekonomice.

Obě př́padové studie jsou di̊kazem toho, že počáteční soukromé iniciativy přinesly pozitivní výsledky zejména tím, že se spojily se státními orgány na úrovni ministerstev za účelem praktické realizace řady kroků podporujících přechod k tržní ekonomice ve finanční sféře.

IPRFT vyvinul během činnosti v letech 1991-1998 mimořádné úsilí, s cílem, co nejvíce přispět k rozvoji českého kapitálového trhu, odpovídajícímu standardům evropské finanční sféry. Tento cíl byl programově orientován na podporu takové obsahové náplně finančních znalostí dospělého obyvatelstva činného ve vznikajici finančni sfére národniho hospodářství ČR, které by odpovídalo mezinárodním zvyklostem a kulture, existující ve vyspělých západoevropských zemích. Mezi ně se ČR hodlala co nejdříve zařadit: v r. 1995 vstoupila do OECD.

Tento záměr vycházel z nutnosti aplikace mezinárodních principů podnikání na kapitálových trzích, což znamenalo: co nejvíce se přiblížit k obsahu vznikajícího českého zákonodárství v oblasti kapitálového trhu (včetně zabezpečení standardního postavení burzy cenných papírü), požadavek respektu a úcty k platným zákonům finanční sféry a jejich přibližování $\mathrm{k}$ obsahu a úrovni mezinárodně uznávaných standardů, podporu úsilí o vznik odpovídajících institucí finanční sféry, zejména Komise pro cenné papíry jako vrcholného orgánu dozoru na finanční trh, snahu o zvyšování nároků na všechny účastníky kapitálového trhu, směřující ke zvýšení potřebné úrovně transparentnosti jejich činnosti, požadavek zvyšování odborné kvalifikace pracovníků finanční sféry a k dodržování deklarovaných etických zásad podnikání na kapitálovém trhu.

Během své činnosti se obě uvedené společnosti tyto zásady důsledně snažily dodržovat, i když leckdy ve svi̊j neprospěch. Za významné a úspěšné lze považovat napřr. úsilí IPRFT upozorňovat na vysoká rizika spojená $\mathrm{s}$ předčasným zavedením obchodování s finančními deriváty na veřejných trzích, které by $\mathrm{v}$ tehdejších chaotických poměrech pravděpodobně mělo velmi negativní dopady (včetně měnových).

Neveřejné publikace obou společností (IPRFT a CMI) byly ze strany př́jemců vysoce hodnoceny, nebot' jim ve stručné podobě přibližovaly obsah a smysl sporných stanovisek různých zainteresovaných stran (včetně různých doporučení a návrhů změn), a také doplňovaly znalost mezinárodních standardů a stanovisek mezinárodních organizací.

Většina uspořádaných přednáškových kurzů měla velmi kladnou odezvu u posluchačů. Většina kurzů měla základní úroveň obtížnosti (tzv. basic), část měla střední úroveň obtížnosti (tzv. inter-mediate). Způsob výuky odpovídal vysokoškolské úrovni. Kurzy prokazatelně sehrály mimořádně pozitivní úlohu při formování finančního vzdělávání značného počtu pracovníkì finanční sféry $v \check{C} R$. 


\section{ZÁVĚR}

V poslední kapitole této knihy (kap. 10) byly shrnuty hlavní konkrétní výsledky zkoumání změn vzájemného vztahu mezi reálným vývojem českého kapitálového trhu a vývojem neformálního finančního vzdělávání dospělých během významných let transformačního období. Na závěr publikace jsou zde vyzdviženy pouze dvě stručně formulované obecnější myšlenky: Předně, je pojednáno o měnícím se vztahu mezi samovývojem rodícího se českého kapitálového trhu a jeho finanční regulací; za druhé, o prŕččnách specifické disproporce mezi kvalitativním a kvantitativním zkoumáním vzájemného ovlivňování obou zkoumaných součástí výše uvedeného vztahu.

1) Závislost a podmíněnost vývoje finančního vzdělávání vývojem událostí na vznikajícím kapitálovým trhu je obecně uznávána. Nelze však nebrat zřetel na to, že úroveň (míra) tohoto vztahu na kapitálových trzích různých zemí je odlišná. V 90. letech byly počáteční rozdíly mezi dynamikou růstu kapitálových trhů středoevropských a východoevropských zemí výrazné a $\mathrm{v}$ průběhu daného desetiletí se ještě více diferencovaly. V těchto zemích se v prvních letech po vyhlášení přechodu k tržní ekonomice vytvářely nové politické mocenské elity, které rozhodovaly jak o dalším politickém vývoji dané země, tak o její hospodářské politice. Vliv politiky při tom se stal dominujícím faktorem vývoje společnosti.

Specifickým znakem vývoje v ČSFR a ČR v počátečním období 90 . let byla postupná nenásilná výměna státního aparátu a postupné změny v legislativě, které však při jejich praktickém zavádění narážely na mnoho překážek. Politický požadavek deklarující nutnost nastolit „svobodu podnikání“ byl v praxi deformován na snahu po absolutní liberalizaci, která se - při nezkušenosti a mnohdy i neschopnosti politických elit - měnila v chaos, nebot' byla (pod záminkou tzv. svobody) značně zanedbávána i elementární regulace.

Vyhlášení programu kuponové privatizace se dnes jeví jako fatální chyba, která v ČR nastolila období podobné éře počátečního kapitalismu: hnací silou podnikání se stal zisk spolu se snahou zmocnit se - jakýmkoliv způsobem - co největšího majetku. Ve vědomí mnoha občanů se tato zkušenost zapsala ve formě lidového rčení, že „kdo si nenakradl, byl neschopný hlupák“.

Pokus o vytvoření standardního kapitálového trhu v podstatě pro neexistenci proveditelné koncepce selhal. Teprve vládní krize v r. 1996 donutila politické elity nastolit alespoň nejnutnější regulační opatření na úseku finančního trhu. Vznik centrálního orgánu finančního trhu se podařilo uskutečnit až v r. 1998. V té době však redistribuce většiny národního majetku ve prospěch malého počtu dravých podnikatelů v podstatě již skončila. V mnoha případech proběhla nezákonnou cestou, vydlážděnou korupcí a podvody. Pozdější okř́idlené heslo „10 českých“ ovládlo terén politiky i ekonomiky a dodnes je hybnou silou rozbujelých zbytečných zprostředkovatelských činností (Wawrosz, 2016). Hlavním výsledkem ,privatizačního obdobi“ však bylo to, že zahraniční kapitál ovládl většinu významných pozic v klíčových hospodářských odvětvích ČR. Možnost zabránit tomu nebo alespoň tuto dominanci omezit vládnoucí elity nevyužily. Bylo by stačilo jen málo: využít zkušenosti 1. republiky o povinném sídlu firmy.

Absolutizovaná dogmatická liberální ideologie a její realizace v politické i hospodářské praxi způsobila české společnosti těžké (objektivně pravděpodobně nevyčíslitelné) ztráty. Bilanci 
střetu mezi liberální ekonomií, ztělesňující chaos, a nezbytnou mírou státní regulace, zajišt'ující občanům v demokratické společnosti jejich základní práva, nelze pro 90. léta pokládat za kladnou.

Případ přechodu ČR ke kapitalistické tržní ekonomice je důkazem toho, kam v 90. letech vedlo nerespektování rad a upozornění zkušenějších. Bohužel často byla dávána (a politicky prosazována) přednost „home made“ výmyslům, účelovým konstrukcím a manipulacím, a to jak ve věci privatizace, tak ve věci vzniku českého kapitálového trhu.

2) Výzkumy prováděné v oblasti různých vědních oborů humanitních věd (včetně aplikované ekonomie) týkající se období 90 . let narážejí na řadu překážek. Některé z těchto překážek mají specifickou povahu podmíněnou předmětem zkoumání, metodami a nástroji daných oborů. Řada $\mathrm{z}$ těchto překážek však je společná: většinou pramení $\mathrm{z}$ obecné situace $\mathrm{v}$ daném zkoumaném období.

Hlavní objektivní překážkou výzkumu, který předcházel sepsání této publikace, nebyl nedostatek pramenů, nýbrž selekce vhodných a použitelných pramenů pro objektivní analýzu zjištěných skutečností. Nad rámec výsledků uvedených v kap. 10 jsou zde stručně zmíněna některá relevantní fakta.

Pramenem kvantitativního výzkumu v oblasti aplikované ekonomie jsou především statistické údaje o zkoumaných jevech a procesech. „Data mining“" však proběhlo negativně v tom smyslu, že existující statistiky obsahovaly údaje v odlišném uspořádání (tř̌idění) než vyžadovalo zjišsění vývoje finančního vzdělávání a jeho úrovně, zúžené na dospělé obyvatele ČR. Existující statistiky vesměs nesledovaly vývoj finančního vzdělávání specificky, ale v proudu údajů o celkovém vývoji školního vzdělávání. Specifická kategorie finančního vzdělávání nebyla v reformované soustavě školského vzdělávání v režii MŠMT považována za relevantní. V tržní ekonomice však finanční vzdělávání představuje samostatnou kategorii.

Celkové statistické údaje o vzdělávání dospělých v 90. letech tedy musely být analyzovány metodami kvalitativního výzkumu. Většinou se tak stalo pomocí expertních odhadů. Tím již je předem dána možnost nepřesných, subjektivně zkreslených výsledkủ.

Většina údajů o finančním vzdělávání dospělých (použitelných pro tuto knihu) byla čerpána z denního nebo periodického tisku; porovnáním četnosti údajů o finančním vzdělávání bylo možno odhadnout jejich vzájemné relace. Bylo využito rovněž údajů z vybraných knižních publikací z doby po r. 1998 a vybraných bakalářských a diplomových vypracovaných na několika fakultách vysokých škol.

V současnosti není proces digitalizace starších údajů disponibilních ve výzkumných pracovištích dokončen; digitalizace často sahá pouze po r. 1999 (jako posledního roku 20. století). Starší dokumenty v listinné podobě jsou obtížněji dostupné; mnohé úřední listiny např. jsou v resortních archivech uloženy, avšak jejich dostupnost je omezena předpisy o archivaci, př́p. subjektivním rozhodnutím správy daného archivu. Archivy některých institucí jsou v dezolátním stavu v důsledku omezeného prostoru. Dokumenty soukromých subjektů z 90. let, podléhající archivaci např. v Českém národním archivu, již mohly být skartovány. V posledních nejméně 5 letech již tento archiv nepřijímal dokumenty souvisící s likvidací firem a soukromé subjekty byly nuceny dokumenty v listinné podobě deponovat samy nebo je svěřovat nově vzniklým soukromým depozitářům. Zásada místní př́slušnosti soukromých 
subjektů způsobuje, že např. výroční zprávy jsou uloženy v krajských archivech. Ani v době vzniku této monografie finanční sankce za nepředložení povinných údajů apod. nebyly př́liš účinné (důvody zde nelze podrobněji rozebírat). Např. v soudních archivech některé údaje chybějí nebo nejsou úplné. Není tedy divu, že např. poslanci různých politických stran $\mathrm{v}$ parlamentě argumentují na základě nedostatečných, neověřených nebo neověřitelných údajů. $\mathrm{K}$ tomu ještě jedna poznámka: výše uvedené skutečnosti získané $\mathrm{z}$ existující praxe dávají podnět k zamyšlení, do jaké míry budou historikové nebo jiní badatelé vůbec schopni objektivně analyzovat minulé děje 90 . let v ČR. Výsledkem bádání může být „pravda“" podobná „pravdě“ vyčtené ze zfalšovaných dávných českých kronik. V 21. „digitálním“ století je tato možnost sice skličující, ale reálná. Popírání holocaustu nebo dnešní „fake news“ a podobné propagandistické nebo marketingové excesy jsou toho důkazem. 


\section{LITERATURA}

Adult Education. Cambridge English Dictionary [online] [cit. 2020-03-11]. Dostupné z: https://dictionary.cambridge.org/dictionary/english/adult-education

Adult Education. Encyclopedia Britannica [online] [cit. 2020a-03-11]. Dostupné z: https://www.britannica.com/topic/adult-education

Adult Literacy. OECD [online] [cit. 2020b-03-11]. Dostupné

z: http://www.oecd.org/education/innovation-education/adultliteracy.htm

Andragogika. ABZ.cz: slovník cizích slov [online] [cit. 2020c-03-11]. Dostupné z: https://slovnik-cizich-slov.abz.cz/web.php/slovo/andragogika

BCPP, 1993. Stanovisko BCPP k projektu na založení samostatné opční a termínové burzy v Praze. 1993.

BEDNǍ̌ÍK, Petr, Jan JIRÁK a Barbara SPITZOVÁ-KÖPPLOVÁ, 2011. Dějiny českých médii: od počátku do současnosti. Vyd. 1. Praha: Grada. Žurnalistika a komunikace. ISBN 978-80-247-3028-8.

BOČKOVÁ, Věra, 1995. Aktuální problémy výchovy a vzdělávání dospělých II. Olomouc: Vydavatelství Univerzity Palackého. ISBN 978-80-7067-569-4.

CANADIAN SECURITIES INSTITUTE, 1992. The Canadian Securities Course. ISBN 0317-9451.

ČESKÁ TELEVIZE (PRAGUE, Czech Republic) a Katarína BÍLKOVÁ, 1997. Ročenka České televize 1996. Praha: Česká televize. ISBN 978-80-85005-14-1. c

Definition of Andragogy. Merriam Webster [online] [cit. 2020-03-11]. Dostupné z: https://www.merriam-webster.com/dictionary/andragogy

DOLEŽAL, Jan, Ondřej HORÁK, Michaela HORÁKOVÁ, Bohuslav FIREŠ a Marie MÍKOVÁ, 1992. Finanční účetnictví. Praha: Grada. ISBN 978-80-85623-10-9.

Education. New World Encyclopedia [online] [cit. 2020-03-11]. Dostupné z: https://www.newworldencyclopedia.org/entry/Education

EURYDICE, UNITÉ EUROPÉENNE a EUROSTAT, 2012. Key data on education in Europe, 2012. Brussels: Eurydice. ISBN 978-92-9201-242-7.

FONTAINBLEAU, 1995. Securities Market Development. A Guide for Policy Makers. B. m.: World Bank - Economic Development Institute.

G20/OECD INFE report on adult financial literacy in G20 countries. OECD [online] [cit. 2020-03-11]. Dostupné z: https://www.oecd.org/finance/g20-oecd-infe-report-adultfinancial-literacy-in-g20-countries.htm

GLABAZŇA, Jan, 2016. Proč nemáme stejnou funkční gramotnost? [online]. Brno. Masarykova univerzita. Dostupné z: https://is.muni.cz/th/rlyaa/MDP-J.Glabazna.pdf Hamburská deklarace a Agenda pro budoucnost, Hamburk, 1997. MŠMT $\check{C} R$ [online] [cit. 2020d-03-11]. Dostupné z: http://www.msmt.cz/vzdelavani/dalsi-vzdelavani/hamburskadeklarace-a-agenda-pro-budoucnost-hamburk-1997 
HODINOVÁ, Olga, 2013. Zvyšováni finanční gramotnosti obyvatelstva České republiky [online]. B. m. Jihočeská univerzita v Českých Budějovicích. Dostupné

z: https://docplayer.cz/amp/3196319-Zvysovani-financni-gramotnosti-obyvatelstva-ceskerepubliky.html

International Standard Classification of Education (ISCED): revised version II. UNESCO Digital Library [online] [cit. 2020e-03-11]. Dostupné

z: https://unesdoc.unesco.org/ark:/48223/pf0000105765

JACKSON, Raymond, 1973. Recurrent education - concepts and policies for lifelong learning [online] [vid. 2020-03-11]. Dostupné z: https://www.cese-

europe.org/publications/10-vi-conference-frascati-1973/19-recurrent-education-concepts-andpolicies-for-lifelong-learning

KIRSCH, Irwin S., 2001. The International Adult Literacy Survey (ials): Understanding What Was Measured. ETS Research Report Series [online]. 2001(2), i-61. ISSN 2330-8516. Dostupné z: doi:10.1002/j.2333-8504.2001.tb01867.x

Learning: the treasure within; report to UNESCO of the International Commission on Education for the Twenty-first Century (highlights). UNESCO Digital Library [online] [cit. 2020f-03-11]. Dostupné z: https://unesdoc.unesco.org/ark:/48223/pf0000109590

LIDMILA, Jan, 2019. Formální a obsahová analýza odborného textu, rychlé čtení. B. m.: Ministerstvo kultury.

MATTHEWS, Paul, 2018. Learning Transfer at Work: how to ensure training >> performance. Place of publication not identified: THREE FACES Publishing. ISBN 978-1909552-06-7.

MLČOCH, Lubomír, 2001. Deset lekcí z deseti let české transformace. In: Finance a úvěr, $2001, \check{c} .4$.

MOŽNÁ, Michaela, 2015. Vývoj právní úpravy vzdělávání dospělých v České republice [online]. B. m.: Univerzita Karlova, Filozofická fakulta [vid. 2020-03-11]. Dostupné z: https://dspace.cuni.cz/handle/20.500.11956/83553

Národní program rozvoje vzdělávání v ČR - Bílá kniha (2001). Databáze strategií - portál pro strategické ř́zeni [online] [cit. 2020-03-11]. Dostupné z: https://www.databazestrategie.cz/cz/msmt/strategie/narodni-program-rozvoje-vzdelavani-v-ceske-republice-bilakniha

Národní strategie finančního vzdělávání 2010. MŠMT ̌̌R [online] [cit. 2020-03-11]. Dostupné z: http://www.msmt.cz/vzdelavani/zakladni-vzdelavani/narodni-strategiefinancniho-vzdelavani-2010

NEJTEK, Jaroslav a Lenka TESAŘÍKOVÁ, 1994. Obchod s cennými papiry: Co by mél znát maklér, aneb každý z nás. Brno: Cepatra Invest.

OECD Conference on Financial Education. OECD [online] [cit. 2020-03-11]. Dostupné z: http://www.oecd.org/daf/fin/financial-education/oecdconferenceonfinancialeducation.htm

PALÁN, Zdeněk, 1997. Výkladový slovnik vzdělávání dospělých. Praha: Daha. Edice Promos. ISBN 978-80-902232-1-9.

PALÁN, Zdeněk, 2002. Lidské zdroje: výkladový slovník; výchova, vzdělávání, péče, řizení. Vyd. 1. Praha: Academia. ISBN 978-80-200-0950-0. 
PALÁN, Zdeněk, 2007. Andragogika a vzdělávání dospělých v datech. Andragogika: čtvrtletník pro vzdělávání dospělých. 11(3). ISSN 1211-6378.

PALÁN, Zdeněk. Základy andragogiky. PDF Stažení zdarma [online] [cit. 2020i-03-11]. Dostupné z: https://docplayer.cz/900825-Zdenek-palan-zaklady-andragogiky.html

PAVLÁT, Vladislav, 2007. Jak vznikala pražská burza cenných papírů. ACTA VŠFS. 2007(2), 066-078. ISSN 1802-792X.

PAVLÁT, Vladislav, 2008. O vzniku Burzy cenných papírů Praha, a.s., 2008.

PAVLÁT, Vladislav, 2014. The Birth of the Prague Stock Exchange. B. m.: Didaktis. ISBN 978-80-8166-004-7.

PAVLÁT, Vladislav, 2018. Prague stock exchange (1993-1997). B. m.: Vysoká škola finanční a správní, a.s. ISBN 978-80-7408-178-1.

PAVLÁT, Vladislav et al., 1994. Makléřské minimum - Př́ručka pro maklére, díl I-IV. 2. vyd. B. m.: IPRFT I-IV.

PAVLÁT, Vladislav a Antonín KUBÍČEK, 2004. Regulace a dozor nad kapitálovými trhy. Praha: Vysoká škola finanční a správní. ISBN 978-80-86754-13-0.

PAVLÁT, Vladislav, 1994. Finanční opce. Praha: Magnet-Press : Institut pro podporu rozvoje finančního trhu. ISBN 978-80-85847-19-2.

PAVLÁT, Vladislav, 1993. Kapitálové trhy a burzy ve světě. Praha: Grada. ISBN 978-8085424-90-4.

RABUŠICOVÁ, Milada, 2002. Gramotnost: staré téma v novém pohledu. Brno: Masarykova univerzita, Filozofická fakulta : Georgetown. ISBN 978-80-210-2858-6.

Ročenky Českého rozhlasu. Český rozhlas [online]. Praha, 2010 [cit. 2020-03-11]. Dostupné z: https://informace.rozhlas.cz/rocenky-ceskeho-rozhlasu-7738227

ŘÍHOVÁ, Barbara, 2013. Finanční vzdělávání a jeho místo ve školním vzdělávání. Praha. Univerzita Karlova.

TYLŠAROVÁ, Eva, 2014. Druhy vzdělávání dospělých (profesní, občanské, zájmové) [online]. B. m. [cit. 2020-03-11]. Veřejně správní akademie - vyšší odborná škola, s.r.o. Dostupné z: https://theses.cz/id/jhzubj/

Úvod do pedagogiky. Pedagogická fakulta Masarykovy univerzity. [online] [cit. 2020h-0311]. Dostupné z: https://is.muni.cz/elportal/estud/pedf/ps09/uvod_ped/web/struktura.html VEČERNÍK, Jiří a Petr MATĚJU゚, ed., 1998. Zpráva o vývoji české společnosti 1989-1998. Vyd. 1. Praha: Academia. ISBN 978-80-200-0703-2.

VYCHOVÁ, Helena, 2008. Vzděláváni dospělých ve vybraných zemích EU. Praha: VÚPSV. ISBN 978-80-7416-017-2.

WÁGNER, Karel, 1992. Burza cenných papírů. Praha: Anomal. ISBN 978-80-900235-9-8.

WAWROSZ, Petr, 2016. Korupce v redistribučním prostředí - Česká republika, Evropa, svět. ISBN 978-80-88018-07-0.

WORLD BANK, ed., 1999. Czech Republic: capital market review. Washington, D. C.: World Bank. World Bank country study. ISBN 978-0-8213-4505-4. 


\section{Publikace IPRFT (bez ISBN)}

Makléřské minimum (1. vyd. 1993)

Memorandum k problematice zaváděni a regulování termínových obchodů na současném českém kapitálovém trhu (červen 1993)

Makléřské zkoušky v zahraničí - část 1: Velká Británie (ř́ijen 1993)

Systémy opčních obchodi̊ na opčním trhu MONEP Pařžžé burzy (listopad 1993)

Zásady profesni etiky maklérù (listopad 1994)

Zásady pro šírení cenově citlivých informací (prosinec 1994)

Základní standardy chování finančních firem (prosinec 1995)

Výsledky britského průzkumu postojů významných institucionálních investorů k portfoliovým investicím ve střední a východní Evropě (květen 1995)

Zásady regulace obchodování deriváty na českém kapitálovém trhu (prosinec 1995)

Základní standardy chování finančních firem (prosinec 1995)

\section{Publikace a expertízy CMI (bez ISBN)}

Vladislav Pavlát: The Creation and Development of the Capital Market in the Czech Republic 1990-1994 (červen 1995)

Úvod do teorie derivátů a uplatnění derivátů v praxi (1997)

Úvod do teorie derivátů a jejich aplikace (únor 1997)

Pracovni podklady pro př́pravu na makléřskou zkoušku (září 1997)

Uloga investicionih fondova i privatizaciji (srpen 1997)

V r. 1994 kromě toho CMI vydal společně s vydavatelstvím Magnet-Press knižní publikaci „, Kapitálový trh v České republice - The Capital Market in the Czech Republic - 1993-1994“ (souběžně v češtině a angličtině). 


\section{REJSTŘÍK OSOB}

Bárta, J. 89

Bednařík, P. 57

Beneš, M. 28

Bird, B. 92

Budík, J. 51

Bureš, J. 71

Čerych, L. 34

Doležal, J. 75, 84

Dyba, K. 15

Fireš, B. 84

Franc, J. 89

Glabazňa, J. 32

Hanuš, V. 69

Hodinová, O. 27

Jackson, R. 23

Ježek, T. 92

Ježková, M. 96

Kalvoda, J. 92

Kaucký, V. 89

Kavánek, P. 53

Kirsch, I. 31

Klapal, J. 89

Klaus, V. 11, 41, 48, 83

Kleiman, J. 92

Koblic, P. 89

Kočárník, I. 44, 48, 83, 84

Köpplová, B. 57

Kubíček, A. 41, 43, 45, 50, 89, 96

Kučera, M. 51, 89

Libnar, D. 96

Liška, V. 96

Lusk, C. 51

Matthews, P. 34
Mejstř́k, M. 96

Miková, M. 84

Miller, J. 15, 43, 44, 57, 103

Mlčoch, L. 7

Morgenstern, C. 92

Možná, M. 8, 18

Novotný, V. 89

Palán, Z. 26, 34

Pavelka, Z. 71

Pavlát, V. 12, 13, 15, 36, 41-43, 45, 49-51, 53, 58, 59, 69, 71, $73,75,76,83,89,92,94-96$

Pavlátová, J. 71, 96

Pegues, J. E. 92

Pospíšil, R. 27

Purkyně, M. 15, 54, 55

Rabušicová, M. 27

Rajda, I. 89

Ríhová, B. 26

Simonová, N. 32, 35

Školout, V. 89, 96

Slosiarik, P. 89

Tošovský, J. 49

Tylšarová, E. 26

Vácová, A. 51

Vilim, G. 69

Vlasák, P. 89

Vohlmut, I. 51

Vychová, H. 26, 27

Wawrosz, P. 27, 70, 107

Yener, D. 92

Záškodný, P. 75, 76, 95, 96

Zíka, O. 54, 71, 89, 95, 96

Zoubek, J. 69 


\section{SEZNAM ZKRATEK}

AOM - Asociace obchodníků cennými papíry a makléřů

BCPP - Burza cenných papírů Praha

CKP - Centrum kuponové privatizace

CMI - Capital Market Institute

ČKT - český kapitálový trh

ČNB - Česká národní banka

CPMM - soukromá firma

ČR - Česká republika

ČSFR - Česká a Slovenská federativní republika

ČSOB - Československá obchodní banka

ČT - Česká televize

ECONORG - česká soukromá firma

EDI - Economic Development Institute of the World Bank

FMF - Federální ministerstvo financí

IALS - International Adult Literacy Survey

IPRFT - Institut pro podporu rozvoje finančního trhu

ISCED - The International Standard Classification of Education

JEL - klasifikační systém amerického časopisu Journal of Economic Literature

$\mathrm{KCP}$ - Komise pro cenné papíry

MFČR - Ministerstvo financí České republiky

MŠMT - Ministerstvo školství, mládeže a tělovýchovy

OECD - Organizace pro evropskou hospodářskou spolupráci

$\mathrm{OM}$ - Option Market

PIAAC - The Program for the International Assessment of Adult Competencies

RM-S - organizátor trhu

SBČS - Státní banka československá

SIALS - Second International Adult Literacy Survey

SCOPUS - citation database of peer-reviewed literature: scientific journals, books and conference proceeding

SCP - Středisko cenných papírů

UNESCO - The United Nations Educational, Scientific and Cultural Organization

WoS - Web of Science 


\section{SEZNAM TABULEK}

Tab. 1 Základní údaje

Tab. 2 Témata finančních kurzů nabízených v r. 1995 v týdeníku Ekonom

Tab. 3 Podíl jednotlivých agentur na nabídce finančních kurzů

Tab. 4 Struktura obsahu měsíčníku ABK (1994-1996)

Tab. 5 Programové typy pořadů ve vysílání České televize v roce 1997

Tab. 6 Zájem posluchačů o témata závěrečných prací

Tab. 7 Složení účastníků semináře podle typu organizace/instituce

\section{SEZNAM GRAFŮ}

Graf 1 Myšlenková mapa 5 kritérií př́istupů k pojetí dospělosti

\section{SEZNAM BLOKŮ}

Blok 1 Významné události na kapitálovém trhu ČR a ve finančním vzdělávání

Blok 2 Financování vzniku BCPP

Blok 3 Zařazení knihy do mezinárodní klasifikace

Blok 4 Andragogika

Blok 5 Mezinárodní výzkum gramotnosti

Blok 6 Schéma druhů gramotnosti

Blok 7 Problémy nové české legislativy po r. 1990

Blok 8 Zápis z jednání poradní komise MFČR

Blok 9 Odborné semináře pro pracovníky bank a spořitelen (březen-červen 1991)

Blok 10 Specifický problém: obchodování s finančními deriváty

Blok 11 Nabídka vzdělávacích kurzů IPRFT v r. 1993

Blok 12 Doporučení k rozvoji českého kapitálového trhu, přijatá účastníky mezinárodního semináře konaného ve dnech 22-23. května 1996 ve spolupráci EDI a CMI v Praze

\section{SEZNAM EXKURZŮ}

Exkurz 1 Finanční vzdělávání v zahraničí v první polovině 90. let

Exkurz 2 Přínos týdeníku Ekonom a měsíčníku ABK k finančnímu vzdělávání

Exkurz 3 Obsah archivu České televize v r. 1997

Exkurz 4 Maklérské kurzy

Exkurz 5 Komentář k obsahu publikací vydaných IPRFT a citace vybraných doporučení IPRFT

Exkurz 6 Ediční činnost CMI 


\section{AUTHORS' CV}

Doc. Ing. Vladislav Pavlát, CSc.

Vladislav Pavlát completed his studies in economics at the University of Economic Sciences in Prague, later receiving the Candidate of Sciences (CSc.) degree at the University of Economics in Prague and becoming an Associate Professor (Docent) in economics. For many years, he worked at the Research Institute of Engineering Technology and Economics, focusing on management and organizational management. In 1990, he participated in the preparation for the establishment of the Prague Stock Exchange. As a Vice Chairman of the Preparation Committee for the Stock Exchange Establishment, he underwent foreign internship at the US Security Commission in Washington and in Morgan Stanley in New York. For several years, he was a member of the Exchange Chamber and Chairman of the Trading Committee. In the 1990s, he worked in the management of several companies, later as an advisor. He published the following books: Stock Exchanges throughout the World, Financial Derivatives, and Global Financial Markets (2013). Moreover, he has published tens of essays and papers in various Czech and international publications, particularly in volumes of many international conferences, both in the Czech Republic and abroad. He was the Chairman of the Editorial Board and Editor-in-Chief for the Akcie, burza, kapitál magazine (Shares, stock exchange, and capital). He currently works at the University of Finance and Administration, at the Department of Finance. He has been a guarantor for the Banking specialization for several years. As an editor, he has published and co-authored the following publications: Capital Markets, Capital Markets Regulation and Supervision, and Financial Markets Regulation and Supervision. As an expert guarantor, he took part in the organization of international conferences of the University of Finance and Administration in the area of financial markets and their regulation in 2005, 2007, 2009, 2011, and 2013, and authored Volumes from these conferences. 


\section{SUMMARY}

The book „Financial education of adults and its level in the Czech Republic in the 90ties“ („Finanční vzdělávání dospělých a jeho úroveň v ČR v 90. letech“) was finalized in May 2020. It presents the authors' research results based on his long-year experience on the field of university education, research, and business activities.

The book contains the following parts: Preface, Introduction, 10 Chapters, Conclusions, References (list of tables, list of blocks, list of excurses, cited persons' index, list of abbreviations, reviewers' CVs, authors' CV and Annex). The book size was limited to approx. 150 pages by the publisher (for technical and commercial reasons).

First, let us briefly explain the content of the 10 chapters: Chapter 1 presents the general characteristics of the research period $(1990-1997)$. Chapter 2 explains the research object, sources and methods. Chapter 3 gives a survey of different definitions of the two basic notions - education and financial literacy. Chapter 4 describes the influence of the import of know how on the field of financial education from the western countries to the Czech Republic and analyses the main barriers of the education transfer caused by the transition from the so-called socialism to capitalism. These four chapters (as a whole) characterise and analyse the general milieu of financial education transfer to the Czech Republic. They form approx. one third of the content of the book. The second third of the content of the book follows the institutional line of research. The role of the Ministry of Finance (Chapter 5), the Central Bank (Chapter 6) and the Prague Stock Exchange (Chapter 7) and the mutual interaction of the capital market formation and the process of financial education in the Czech Republic is analysed. Chapter 8 examines the role of media on the Czech capital market. The last third of the book (Chapter 9 and 10) deals with the role of two private companies in the brokers' education.

Second, let us explain the concept of the book. The book contains the main results of our research about adults' financial education (mainly education of financial sector professionals) described by terms of JEL in the following way: A2. Economic Education and Theory of Economics: A29 (other); B2. History of Economic Thought since 1925: B29 (other); I. Health, Education and Welfare: I22 Educational Finance. However, to be able to analyse the interaction between the capital market and financial education, it was necessary to ,step on the neighboring territory" of other disciplines such as sociology, pedagogy and andragogy, psychology etc. Through this step, the book gained its inter-disciplinary character. It would be useful, to deal with juridical questions as well; it was not possible because of the above size limits. Originally, the author had the intention to deal with the question of financial education in a broader sense, i.e. not only for the category of adult persons.

Third, from the 25 years" distance, an approach called "sine ira et studio", it was possible to reach an emotionless, objective approach. It was quite difficult, because many questions of financial capital functioning and financial education are still unsolved and questionable. It was a challenge for the author to present an adequate picture of what had happened long years ago - and to publish selected original documents from his archive as a gift to the future researchers. The book contains a number of new original research results. The research was based on the idea that a mutual dynamic interaction of the securities markets' functions (financial market infrastructure included) and financial education (financial literacy degree) has to exist. For the 
first time in the Czech financial literature, the above idea was applied consequently; at the same time, a five-tier approach was used. The multi-dimensional approach enabled the confrontation of the Czech education level with the education level in developed countries. In all parameters, both the Czech financial market and the financial education lagged behind the developed countries. At the same time, the level of financial education in the Czech Republic substantially lagged behind the level of the Czech capital market. In the book, a new periodization was prepared to be able to identify the specific feature of each of the three sub-periods. The results confirm that only the financial literacy level in the segment of professional financial education of brokers met the Czech capital market needs since 1993 up to 1997. The first official concept of financial education (as one of the parts of a general concept of education) was approved by the Czech Ministry of Education in the year 2010. In our book, the main deficiencies or barriers to a standard Czech capital market development - typical for the examined research period of the researched topics - were systematically described and analysed. The false mantra of a successful coupon privatisation, of an independent Czech national capital market development etc. was revealed (based both on criticism of the Czech and foreign authors). In different parts of the book, the need of further research on the field of adults' financial education in the Czech Republic is declared. 


\section{Pर̌ÍLOHY}

\section{2}

Komise pro koordinaci rozvoje kapitálového trhu. (Jmenovací dekret 12. 2. 1992.) Kap. 8.

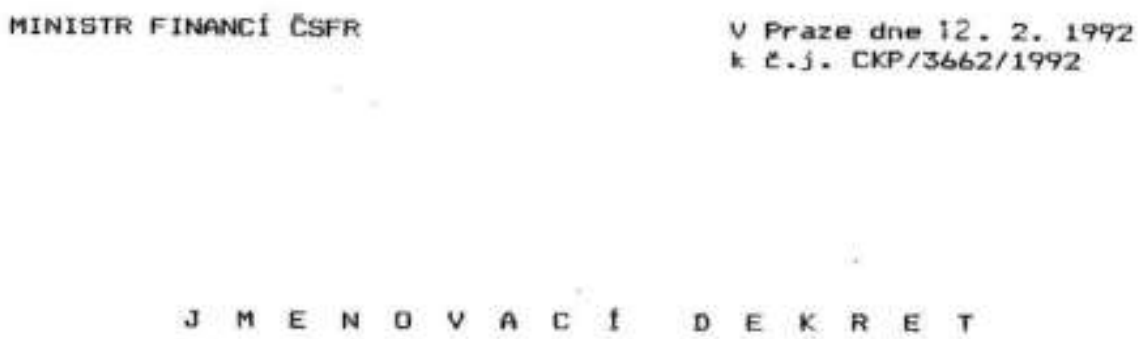


Poradní komise MFČR pro udělování povolení k obchodování cennými papíry. (Jmenovací dekret z 23. 10. 1992.) Kap. 8.

\title{
MISTOPŔEDSEDA VLÁDY ČESKÉ REPUBLIKY \\ a ministr financi \\ Ing. Ivan Koidirnik, CSG.
}

\author{
$V$ Praze dne 23. Ífna 1992 \\ čj. $102 / 59254 / 1992$
}

vážený pane,

jmenuji Vás členen poradnf komise ministerstva
financl České republiky pro udělovánf povoleni k
obchođování s cennými papíry.

S pozdravem

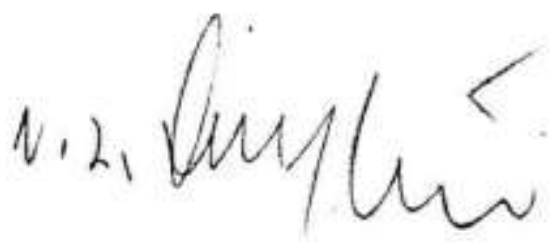

\footnotetext{
Vảžený pan

Doc.ing. Vladislav $P$ a v 1 á $t$, CSc.
} 
Žádost IPRFT adresovaná MŠMT o pověření vydávat doklad o rekvalifikaci. (25. 5. 1993.) Kap. 8.

INSTITUT PRO PODPORU ROZVOJE FINANCNIHO TRHU,S.r.D.

110 oo Praha 1, skolska $16 \quad$ tel. 263088

Ministerstvo skalevi, aladeze a telovtchovy ER

odbor 34 - "editel Fibr. Zdenek. Palan

Karmelitska 7

110 oo Prata 2

$\checkmark$ Praze dne 25.5 .1993

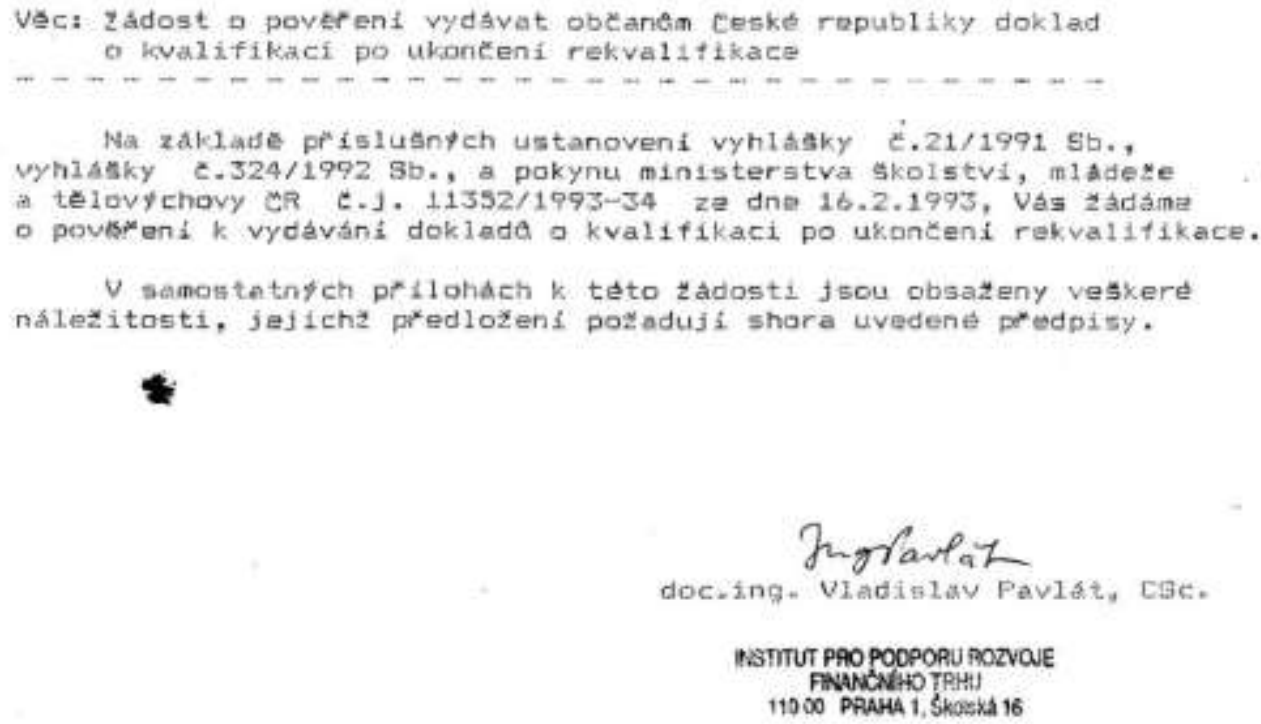


Pověření MŠMT k vydávání dokladů o rekvalifikaci. (4. 6. 1993.) Kap. 8.

Ministerstvo školství, mládeže a tĕlovýchovy ČR

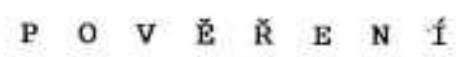

k vydávání dokladú o kvalifikaci po ukončení rekvalifikace ve smyslu vyhlášky MPSV C̆R č. $21 / 91$ Sb, resp. ve zněni vyhlás̆ky MPSV CR č. $324 / 92 \mathrm{Sb}$.

Číslo : $\quad 18426 / 93-34 / 216$

Název organizace : Institut pro podporu rozvoje finančniho trhu, spol. s r.o.

Adresa, PSČ :

Skolska 16, 110 oo Praha 1

Komise pro akreditaci vzdĕlávacích zařizenỉ posoudila seznam pracovnich činností, pro které se požaduje povĕreñi, úroveñ odborné a pedagogické kvalifikace vyučujicích, stav projektové př́pravy. vzdĕlávacích aktivit, zajištěni a vybaveni učeben.

Komise pro akreditaci vzdělávacích zařízení pověruje výše uvedenou organizaci (firmu) vydávat doklad o ukončení rekvalifikačnich kursů zakončených zkouškou (osvĕdčení s celostátní platnosti) pro tyto pracovní činnosti

- odborný pracovnik finančniho a kapitálového trhu

Platnost pověření se stanoví do 31

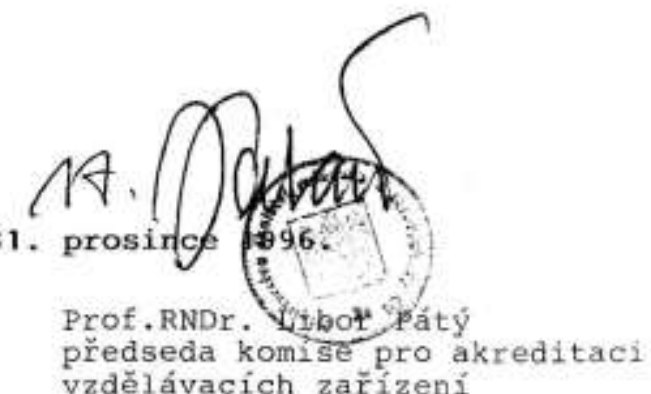


IPRFT. Makléřská zkouška. Otázky soubor 23. (Originál seznamu z r. 1993.)

23.

Ministerstvo financi

Ceské republiky

\section{MAKLÉŘSKÁ ZKOUŠKA}

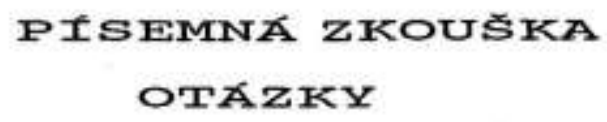

C

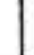

j

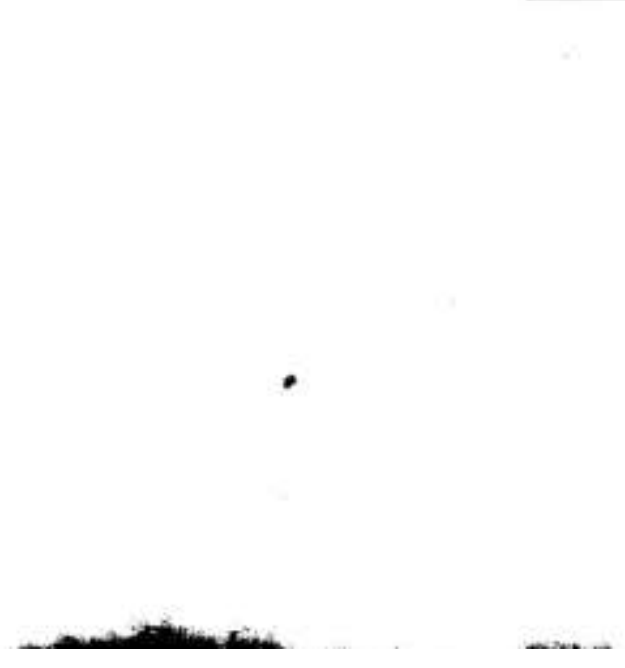


1. Nejvĕtšim primárnim trhem zlata na svétẻ je
A. Zürich
B. New York
C. Londȳn
D. Tokio

2. Povoleni $\mathrm{k}$ založeni burz cenných papirû $\mathrm{v}$ C̆R vydává

A. żivnostenský úrad $v$ sidle burzy

B. vláda ČR

C. obecni úrad $\mathrm{v}$ sidle burzy

D. guvernér české národni banky na návrh ministra financi

3. Klamným prodejem se rozumi

A. dohoda o prodeji, př̀i kterém nedojde $\mathrm{k}$ pŕedảni cenných papirů

B. dohoda o prodeji, při kterém nedojde $\mathrm{k}$ pŕedáni kupni ceny

C. předstiraný prodej, př̀i kterém nedojde ani k pr̃edáni zboži,

ani $k$ předáni kupni ceny

D. žádná $\mathrm{z}$ výśe uvedených možností

4. Burzovni komora mùže mit

A. libovolnỳ počet členú

B. nejvýše 28

C. nejméně 5

D. $7-13$

5. Nejaůlez̃itẻjşi promènnou při hodnoceni alokace kapitálu, investični strategie, výsledku ekonomické aktivity subjektu je

I. zisk, určený rozdilem celkovy̆ch vy̆nosů a nákladû, zmens̉ený o odvody ze zisku, který je napri. podnikem uváděn ve výsledovce.

II. Hospodárský výsledek, určený rozdillem celkových výnosŭ a nákladú, zmenšený o dañ $z$ přijmu, který je napr̆. podnikem uvádẻn ve výkazu ziskû a ztrát.

III. Čistý penẻžni tok (net Cash Flow), určený rozdilem celkových penëżnich pr̂́ijmú a výdajú (včetnẻ výdajủ na nutné či vyvolané investice) $\mathrm{v}$ pevné zvoleném časovém intervalu (napŕ. rok) a jeho časový prủbẻh.

IV. Dimenze pûsobicich rizik.

odpovédi: A. (I.)

B. (II., IV.)

C. (III., IV.)

D. (I.,IV.)

6. Kao musi požádat o povoleni pr̆ijeti cenných papirù $\mathrm{k}$ burzovnimu obchodu ?

A. kterýkoliv obchodnik s cennỳmi papiry

B. člen burzy, který je hodlá uvést na burzu

c. maklèr

D. emitent 
Odpovédi: A. (I.)

B. (II..IV.)
C. (II.,III.)
D. (IV.)

12. Burzovni rozhodei soud (BRS)

I. rozhoduje spory $z$ obchodû uzavíených na Burze cenných papírů Praha, a.s., v souladu s Rádem BRS

II. vydává $\mathrm{v}$ soúladu $\mathrm{s}$ ŕádem BRS po skončeni ústního jeđanáni rozhodčí nálezy, které jsou soudnē vykonatelné po schválení burzovni komorou

III. se skládá $\mathrm{z}$ pŕedsedy BRS, mistopr̃edsedy BRS a rozhodcư

IV. je zr̂́izen burzovni komorou podle § 31 zákona č. 214/1992 Sb.

odpověd : A. (I.,II.,IV.)

B. (I.,III.)

C. (I.,III.,IV.)

D. (I.,IV.)

‥ 13, Bilančni kurs akcie je

I. vypočten jako rozdil mezi vlastnim a cizim kapitálem

II. hodnota vlastního kapitálu na 1 akcii

III. vyuz̃iván pr̂́i mezipođnikovém srovnáváni v rámci oboru

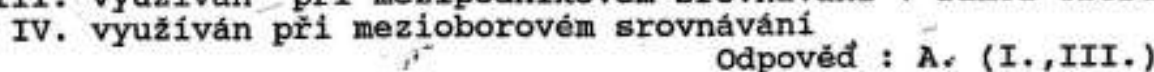

B. (II., III.)

ua-

C. (II.,IV.)

ent 14. Členové praz̃ské burzy

stot

I. směji obchodovat všemi veřejně obchodovatelnyimi cennými papiry znéjícími na českou ménu na burze $i$ mimo burzu bez omezení

II. mimo burzu směji obchodovat s kotovanými cennými papiry

III. mimo burzu sméji obchodovat s nekotovanými cennými papiry

IV. pokud není nekotovanỳ cenný papir zaregistrován na pražské burze, členové burzy s ním nesměji obchodovat mimo burzu

odpověd : A. (I.)

B. (II.,IV.)

c. (III.)

D. (II.)

15. Kurs akcif na burze

I. se obvykle rovná bilančnimu kursu akcie

II. se nerovná bilančnimu kursu akcie

III. je ovlivňován pouze očekávaným vy̛vojem podniku $v$ pr̉ištich letech

IV. silné závisi na ocekávaném zisku pođniku

stés

lu.

téhi

odpověđ : A. II.,IV.)

B. (II., III.)

C. (I.,IV.)

D. (I.,III.) 
Seznam účastníků makléřské zkoušky a její výsledky (27. 5.-18. 6. 1993.)

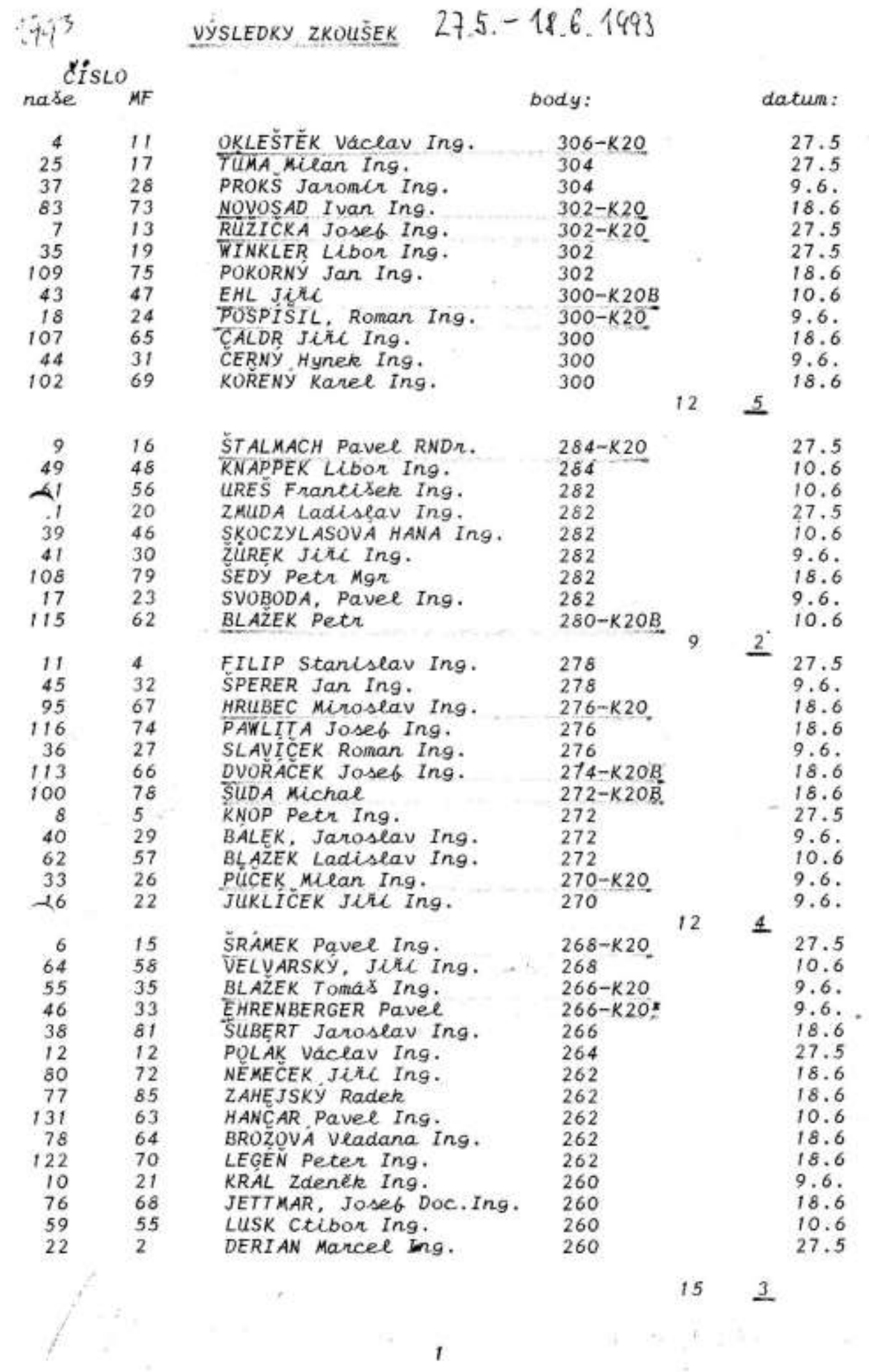


Stanovisko BCPP k projektu na založení samostatné opční a termínové burzy v Praze. (23. 7. 1993.)

\section{Záẫe r}

Burza cennŷch papirủ Praha doporučuje MF ČR nevyhovět żádosti o vydáni povoleni $k$ zalożeni opční a terminové burzy, dokláda toto své stanovisko dủvody uvedeń̛mi vỷse v bodech 1. az̃ 6. Stanoviska.

Domnivame se, ze BCPP je schopna garantovat, aby obchodování $s$ deriváty nebylo zahájeno předčasnē, nŷbrǒ̃ teprve tehdy, az̃ to stupeñ rozvoje kapitálového trhu skutečně umožni.

Jsme pr̆esvědčeni, že BCPP vzhledem $k$ tomu, گ̌e jejimi cleny je pr̂eváñná větŝina 1 icencovań̛ch obchodnikû $s$ cennými papiry z ČR, poskytuje i garanci rádného a Eestného obchodováni s deriváty, az̃ bude tento trh na BCPP otevr̂̃en.

V Praze, dne 23. Eervence 1993 
IPRFT. Průvodní dopis náměstkovi ministra financí ČR k Memorandu k regulaci opčních a termínových obchodů v ČR. (23. 7. 1993.) Kap. 8.

1043

\section{INSTITUT PRO PODPORD \\ ROZVOJE PINANCNÍHO TRHU \\ 11000 Praha 1, Śkolska 16}

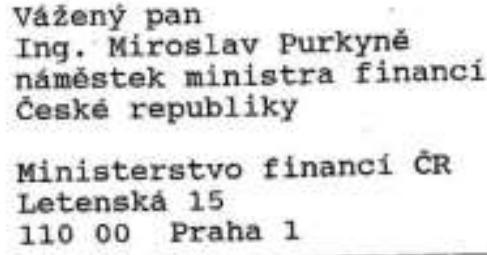

Véc : Memorandum $\mathrm{k}$ regulact opönich

a terminovych obchodú v Č́R

Vážený pane námẽstku,

v rámci činnosti našeho Institutu, který se angaźuje na základē povéreni MF C̆R $\mathrm{v}$ oblasti zabezpečeni makléŕsky̧ch zkoušek, mimo jiné pozorné sledujeme ćinnost Burzy cennyych papirû Praha, RM-systému i dals̄ich subjektũ na vznikajicin českém kapitalovém trhu, a to zejména $\mathrm{z}$ hleaiska zabezpečeni profesionality maklérù a $z$ hlediska bezpečnosti investorů.

Je potěšujici skutečnosti, že základni předpoklady pro nastartováni tohoto trhu byly již vytvořeny. Trh sám však zûstane ješté dlouho nerozvinutỳm a nedokonalým trhem. Zároveñ je zcela zr̉ejmé, z̃e bude snaha na tento trh zảhy uvádét nové prođukty a zavảdĕt dalšil druhy obchodú. Tento proces je zcela zákonitý a logický, avšak zejména $\mathrm{z}$ hlediska ochrany investorû je jistể úcelné jej regulovat. 
Domnivăme se, že dřive nebo pozdēji na našem kapitálovém trhu dojae mj. i k zavedeni opčnich a terminových obchodủ. Vzhledem $k$ aktuálnosti této otázky si dovolujeme předložit vám stručné Memorandum, v nēmž shrnujeme poznatky, které jsme ziskali studiem zahraničnich zkušenosti a konzultacemi s našimi zahraniénimi partnery.

Budeme velmi rádi, bude-li prilležitost vyuz̃it myšlenek obsaženych $v$ tomto Memorandu $v$ procesu regulativní činnosti MF ČR ve prospěch ceského kapitálového trhu.

$\mathrm{v}$ úctè

Ing. Oldr̃ich zika

Institut pro podporu rozvoje

finančniho trhu

Přiloha : Memorandum 
Návrh na zabezpečení přípravy opčních a termínových obchodu. Podklad pro Burzovní komoru z 29. 7. 1993.

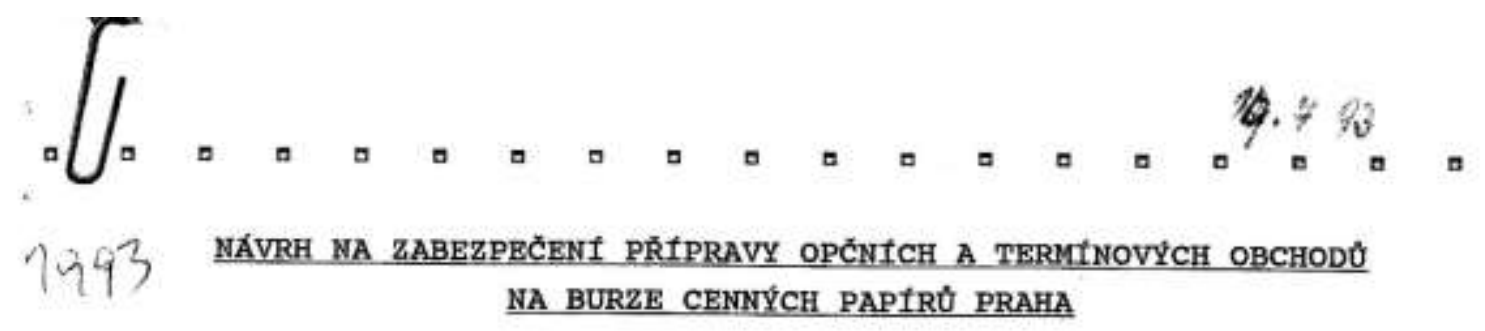

\section{Současný stav a koncepce rozvoje BCPP}

1.1. BCPP zahájila činnost 6.4 .1993 promptnimi obchody. Tim byla dovršena prvni etapa rozvoje BCPP. Vybor pro burzovni obchody ihned po ukonćeni této prvni etapy zahájil v květnu t.r. práce na připravě dalšiho rozvoje BCPP. Výbor doporučil, aby $v$ rámci BCPP byla zabezpecena pr̉iprava $\mathrm{k}$ zahájeni opčnich a terminových obchodũ, které by tvor̂ily odělený segment trhu, a pověr̉il předsedu výboru informovánim Burzovni komory.

Tato informace byla prednesena na zasedáni Burzovní komory dne $\ldots \ldots \ldots$ a vzata na vědomi. Souběžně probihala jednáni se zástupci Pař́ižské burzy o možnostech spolupráce na dalši etapé rozvoje BCPP. Tato jednání dosud nejsou uzavřena.

1.2. Dalši rozvoj kapitálového trhu $v$ Č́ príináśi sebou nutnost postupnè na tento trh uvádét dalši produkty. Tento vy̛voj pújde nejen cestou kvantitativni, tj. zvyšovánim objemu obchodú s cennými papiry, ale $i$ cestou kvalitativni, tj. zavedenim obchodú $s$ tzv. deriváty cenných papirú (opcemi, finančnimi kontrakty apod.), zkvalitnénim technického zabezpečeni obchodováni $v$ podobě vétšsho komfortu uživatelù (např. spojeni on-line, prùběžné obchodováni, nové druhy přikazú, organizačni vyčlenẻni nĕkterých trhư) a vytvárenim efektivniho kapitálového trhu.

Rozvoj kapitálového trhu $v$ ĆR bude postupný a pravdèpodobnẻ spiše pozvolný. Reálnou ekonomickou základnou rozvoje efektivníno kapitálového trhu je proces tvorby úspor, které jsou jejich majitelé - jestliže existuje 
potřebné politické, právni, institucionálni, sociálnē psychologické, dañové aj. klima, propojený komplex, z něhoź nelze jednotlivé jeho souđásti libovolnĕ vytrhovat. Proto pouze existence institucionalnĕ technické infrastruktury kapitálového trhu sama o sobĕ nemúze vytvoİt efektivni kapitalovy trh. Analogický to plati i pro ostatni výše uvedené podmínky.

1.3. Za nespornou považujeme také skutečnost, že efektivni kapitálový trh (tj. fungujici trh s rovnováz̆nyini cenami, $\mathrm{v}$ nichž se odrážeji dostupné informace) ješté ani zdaleka nemohl vzniknout a je $\mathrm{v}$ samotném pocátku svého vaniku, kdy $k$ rovnovážnỳm cenám i $k$ dostatečném kvantu a kvalité informaci je velmi daleko. Dokud se nevytvori dostatečnè siroký 1 hluboký trh cenných papirû, jako efektivni trh, je velmi riskantni zavadět vedle promptnich obchodú 1 obchody s deriváty, nebot tim neúnosnẻ stoupá spektulativni charakter kapitálového trhu jako celku.

zároven̆ je pravda, že spekulanti znali možnosti spekulace $s$ deriváty, jistě mohou s opčnimi i terminovými obchody již dnes začit $i$ mimo existujici institucionálni strukturu. Dnes sice nemaji sanci ohrozit trh jako celek, avăak nechopi-li se iniciativy $v$ organizováni trhu s deriváty seriosní instituce za jakou povaz̃ujeme BCPP, uchopi tuto iniciativu nékdo jiný, a to ke škodè ceského kapitálového trhu i BCPP.

Tím se stává myšlenka na zavedeni opčnich a terminových obchodû na BCPP vysoce aktualini a pưvodně předpokládaný časový horizont $2-3$ let se značnē zkráti. 
1.4. $\mathrm{z}$ hlediska likviaity trhu je neưnosné - pr̆i existenci fungujici BCPP a RM-systému - tuto likviditu ještĕ dále třiśtit zakládánim dalsich burz nebo jinỵch organizátorú trhu. Mj. 1 proto se jevi jako účelné, aby BCPP podstatnĕ urychlila pr̂̉ipravu $\mathrm{k}$ otevřeni trhu s deriváty.

1.5. Současnè je nezbytné konkretizovat $i$ dalíi rozvojové zámōry včetnē spolupráce předběžně dohodnuté s Pařižskou burzou.

\section{2. priprava $\mathrm{k}$ zahájeni opčnich a terminových obchodú na $B C P P$}

Obsahem těchto pr̂́iprav je zejmena

- definováni okruhu predpokladany̧ch opčnich a terminovych obchodû

- organizace trhu s deriváty

- určeni potr̉eby softwarového a hardwarového vybavení

- předběžnŷ odhad očekávaných nákladú (včetnē nákladů na pr̂fipravu projektu a na vyskoleni personálu burzy)

- stanoveni postupu praci

2.1. Předpokládanŷ okruh opěnich a terminových obchodú :

V první etapĕ zavést americké a evropské opce na akcie a na burzovni inđex. $\mathrm{V}$ đalši etapě zvấit pr̉ipadné rozsirreni a dalši derivâty (např. devizové opce apod.).

2.2. Organizace trhu s deriváty :

Vzhledem $k$ tomu, že opčni a terminové obchody představuji relativnè samostatný segnent kapitálového trhu, jako nejvhodnējüi ṙešeni se jevi vyčlenit tento segment v budoucnu jako dceřinnou společnost BCPP. Prozatim však je účelné ponechat tento trh $v$ rámci existujici organizace BCPP. 
Zakladatelská smlouva Asociace obchodníků s cennými papíry. (4. 8. 1993.)
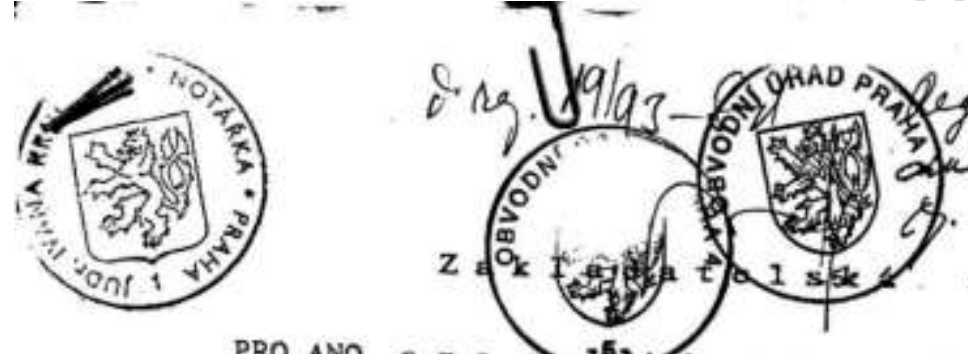

PRO ANO, S.r.O,

výpis $z$ obchodn

odd. a vlozka C $2106 / 93$ rílku obvodniho soudu Praha 1 c.

Dod 0 +es 4

Institut

pro rozvoj kapitálového trhu, s,r,o.

soudu Ústis

of. $6190 / 92$, odd. a vložka C 2666

Ing. Václav Liška,

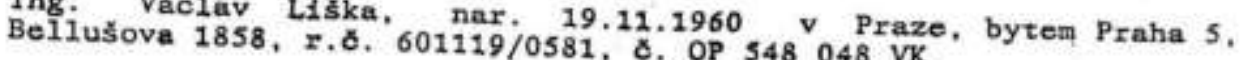

Varnsdorfská 9, r, C. $540422 / 2109$, d., 1954 v Praze, bytem Praha 9.

zakladaj1

Asociaci obchodnikù s cennými papiry /dále jen Asociace/

Sidlo

Předad̆t đ̌innosti

$$
\text { Sulická 26, Praha } 4 \quad 14000
$$

je zejména pr̃ispivat k rozvoji kapitálového trhu nebo se jejupráce vŠech, kteři jej zajištuj 1 nebo se joj úcastni. Dbát na odborné vykonáváni podnikatelských einnosti.

Asociace bude poskytovat svým êlenùm poradenské a konzultačni služby,organizovat vzdêlávací a informačni cinnosti.

Přesným výčtem předmŏtu tčinnosti je ustanoveni

Trváni

nov Asociace.

Jednáni a

podepisováns

Asociace je založena na dobu neurčitou.

Prxi podpisu. této smlouvy se zakladatele dohodli,

że podle cll. 7 Stanov jmenuji predsedou

+) ing. V. Novotného a mistopŕedsedy ing. V. Lisk ku,

kteŕi zastupuliata, CSo. a ing. V. Kauckeho, CSc.

kter̂́ zastupujl a jednajl jménem Asociace

podle 8,9 a 10 Stanov.

rodepisovini so dĕjo podle fo, 01,4 Stanov

listinu svým podpisem

+) optan + dopt.

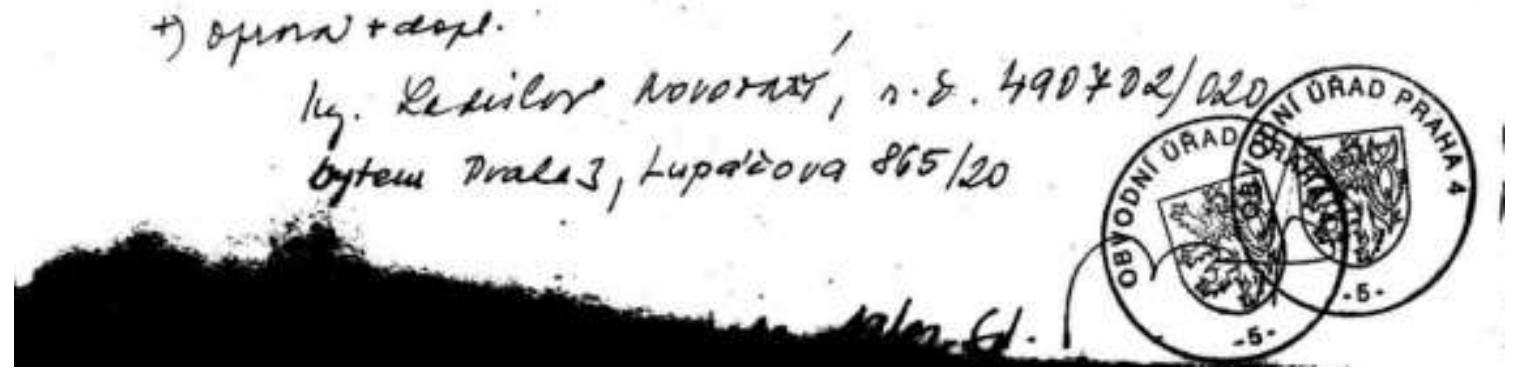


Program semináře IPRFT a Asociace. (14. 10. 1993.) Kap. 8.
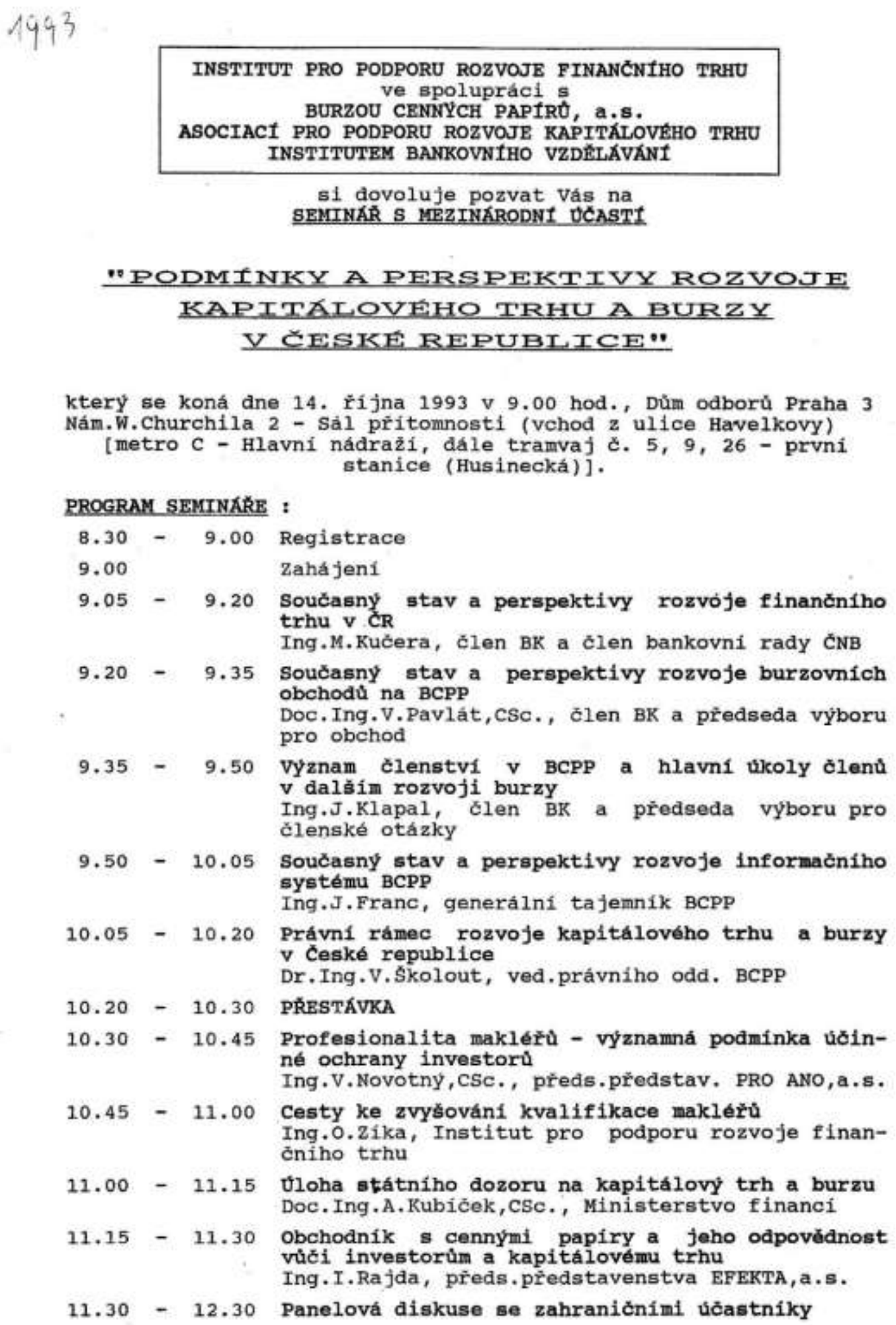
Osvědčení o vykonání makléřské zkoušky. (Specimen.) Kap. 8.

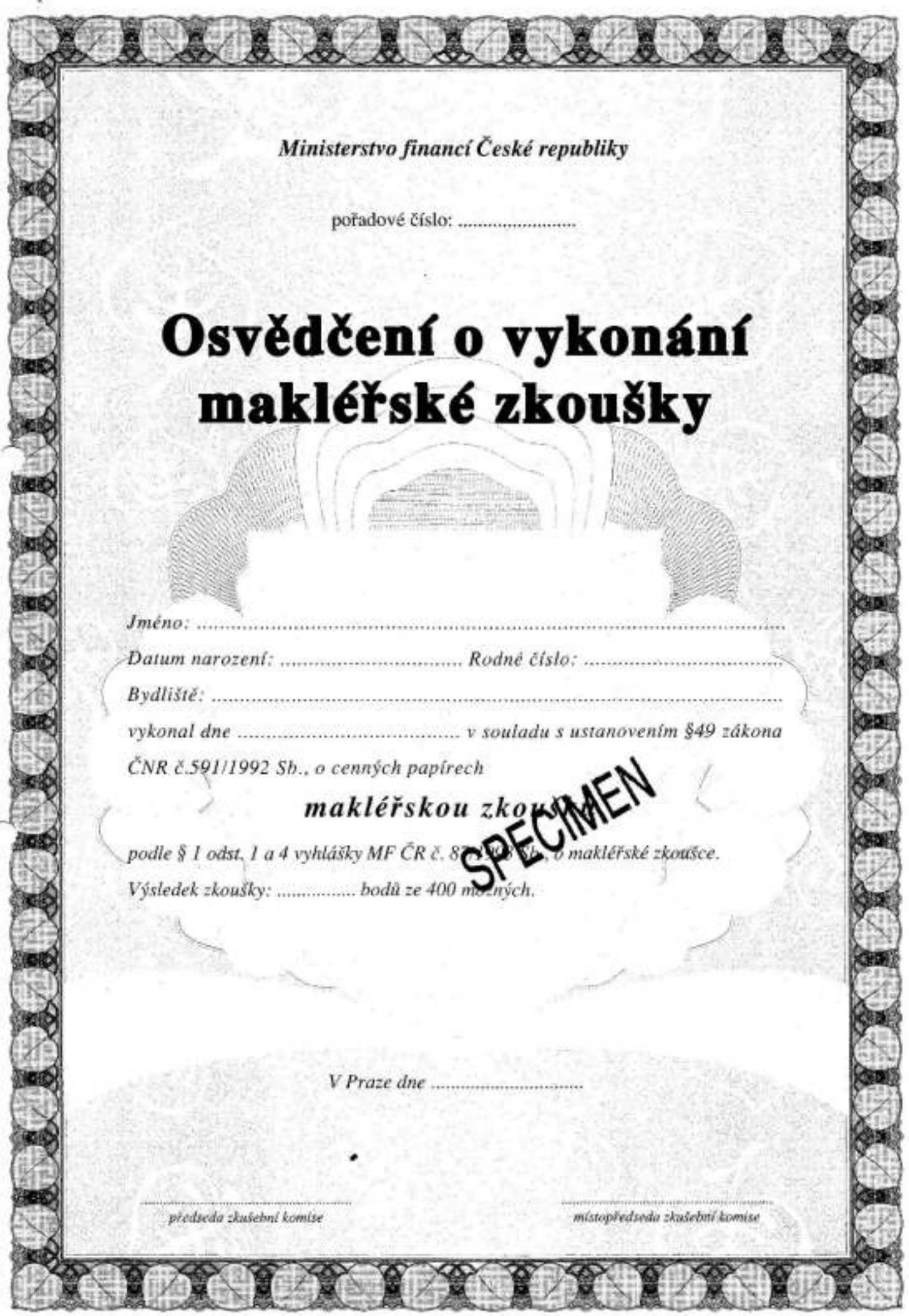


Doplněk k protokolu č. 18 z BK 22. 12. 1993 (res opční burza).

1944

\author{
Doplnếk k protokolu č. 18 \\ ze zasedáni burzovni konory z 22.12 .1993
}

ad 5) $\mathrm{V}$ souvlslosti se znĕnim usneseni $k$ bodu ad 2) o vytvor̆eni opčni burzy upozornil burzovní komlsẩ p. Ulirich na potřebu rychlé prezentace tohoto usnesení a zároveñ oznadil prvý kv, 1994 jako vhodný termin ke zpracováni a pr̆edložení materiálu týkajícího se této otázky MFČ́R k posouzení.

V Praze dne 17. ledna 1994

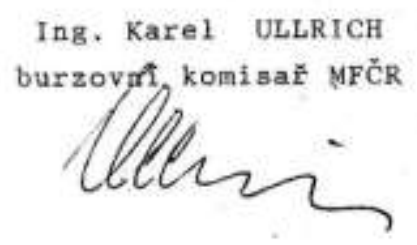


IPRFT. Návrh na uspořádání kurzů pro pracovníky finančních úřadů. (27. 12. 1993.) Kap. 8.

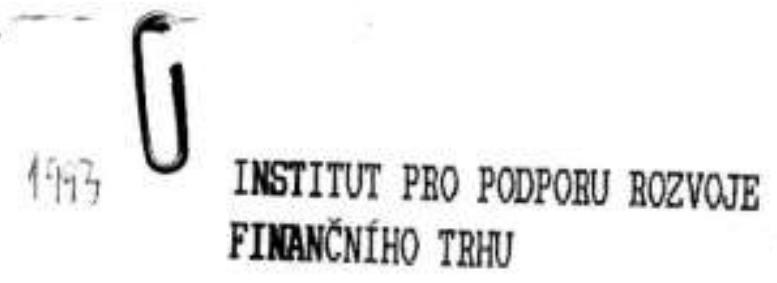

11000 Praha 1, ङ̌kolaka 16

TEL $\angle A A X=(02) 263088$

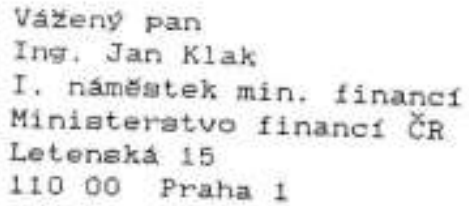

Vażeng pane miniatre.

e dalirm rozvolem ceaksho kapitaloveho trhu vznika mj. potreba ocekiovani cenngoh papira, a to jak portfoli1 invea ticnich fonda, tak portifolis ve viastnictul soukromgch inves-
tora.

Soudasna metodika ocenován1, jak známo, se teprve vytua41 a zFejme bude trvat pomerne dlouho, nez be zformuje tak. aby odpovidala standardem bëznym ve vyepele trżni okonomice. pap1ra, ktery $\vee$ narla praxi predpoklado pro ocehovan cennych tečne znalogtl problemat 1 prozatim nens aplnøn, jacu doatainvest znaloatl problematiky cenngch papfra vabec. Dokud si nebudou echopn znalosti $v$ teto oblasti. Kada problome vetadne ocellovat ava portiolia a bude vznikat Toto\% platid konfliktnich aituacl ge statnimi organy. kontrola spráunogt i pro pracovniky organa, kterym je buärena * darfouymi povinnogtmi cennych papira $v$ souvisiogti Inetitut proplatnfko

Institut pro podporu rozvoje inandniho trhu se nedduno zabłval temito otazkami, ktere povazuje za velmi aktualn $\checkmark$ ramci sudho poslani podporovat fozvoj finaneniho trhu si dovoluje predlożit Vam nasledujicl navrhy

- prabehu roku 1994 uapopadat pro vybrand pracovniky f1nancnich drade č kurz o zakladni problematice cenngch
papiro

- $\checkmark$ probuhu roku 1994 usporadat pro vedoucl pracouniky $t$ nancnich úrade Č trhu, burzy, obchodovani cennymi papiry a jejich oceñovans.

Inatitut pkiprav11 varlantn1 konkretni navrhy na obeahove a organizaęnf zafiztanı tłchto akc1, ktere bych Vam rad co nejdirive predlozi1. Pokud budete uaporadani terchto akc1 povazovat za uzitedine, uvital bych setkani g Vami, pri kterém by bylo mozno zalozitoet, zabadne projednat, aby ae cinnogt In-

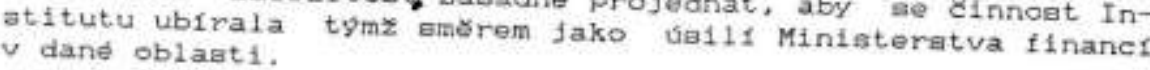

V Praze, dne 27. prosince 1993

Ing. Vladialav pavlat 
Priloha

Seminar o kapitaloydm trhu a cennych papirech

pro vedouct financintch brado čB

(rozaah cea $14-16$ hodin)

1. Kapitalovg trh: pojem, atruktura, instituce, organizace, nátroje - obecne a $v$ ČR

2. Cenne papiry : pofem, klasifikace, typy a druhy cennych papire

3. Zaklady práñ úpravy cennych paplra $v \check{C}_{R}$

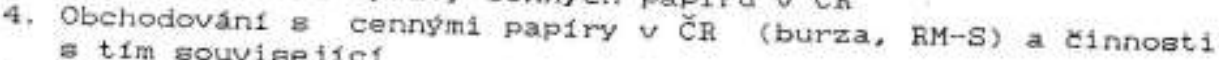
s tim souviaejic1

5. Tvorba cen (kurze) cennych papire na organizovanych trzich 6. Základni teoreticke a prakticke otazky ocerovani hodnoty

\section{Zakladnt kurz o cennych paptrech}

(rozaah cca $40-66$ hodin)

A - 1. Co joou cenne papiry (definice, typy a druhy cennych
papira).

2. Cenne papiry a peunym a proménliugm vánosiem.

3. Dluhop1вy. Druhy dluhoplaa, Cena (kurz) dluhopisa pojem.

4. Zamestnanecke dluhopisy.

5. Komunalnt dluhopiay.

6. Hypotecn1 zastauni liaty.

7. Akcie - pojem, význam, druhy. Rozdll oprotl dluhopiatm.

B. Cena (kurz) akcil-pojem, cinitele ovlivkujici cenu

B. 9. Kapitalovy trh - pojem, deastnici trhu, nastroje, inatituce, organizace, fungovani trhu.

10. Organizovane trhy. Burza cennych papire a BM-eystem.

11. Primarni trh. Emiae cennych papira.

12. Obchodován1 ® cenngmi papiry.

C-13. Tvorba cen (kurza) cennych papira, dluhopied a akcil.

14. Cinitelé ovlivxujici ceny cennych papire.

15. Metody odhadovani vývoje cen cenngch papire.

zakladni a technicka analyza.

16. Metody ocekovani hodnoty cennyeh papira. Nabtroje financin analyzy.

D - 17. Prakticks priklady postupä płi ocekovanf cennych papiro. E: - 18. Pravni úprava platna $v$ C̆R pro oblagti ocetrovant cennych
pap1ra. 
Smlouva o dlouhodobé spolupráci mezi BCPP, a.s. a IPRFT, s r.o. (Návrh z r. 1993.) Kap. 8.

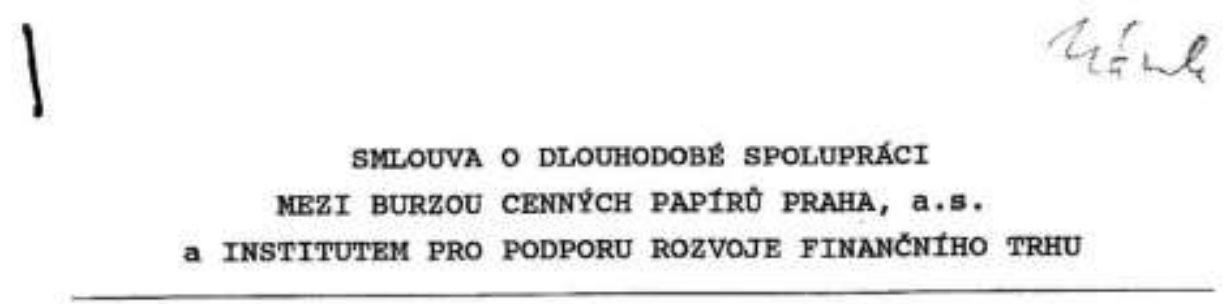

$$
\text { I. }
$$

Smluvni strany

BURZA CENNYCH PAPIRÛ PRAHA, a.s.
se sidlem : 110 00 Praha 1 , Na mústku 3
zastoupená $: \ldots \ldots \ldots \ldots \ldots \ldots \ldots \ldots \ldots \ldots \ldots \ldots \ldots \ldots$

a

INSTITUT PRO PODPORU ROZVOJE FINANĆNIHO TRHU

se sidlem : 11000 praha 1, Śkolská 16

zastoupeny: Ing. Oldrichem zikou

vedeny snahou usilovat o rozvoj finančniho trhu v Ceské republice uzaviraji spolu smlouvu o dlouhodobé vzájemné spolupráci $\mathrm{s}$ obsahem, který je dále vymezen v odstavci II.

$$
\text { II. }
$$

1. Dlouhodobá spolupráce obou organizaci (viz odst. I.) bude realizovảna $v$ téchto oblastech :

a) vydávání popularizačni literatury $v$ oblasti burzovnictvi

b) zpracovani rozború, statistik a informaci o vývoji obchodovani cennými papiry na BCPP

c) poŕăaani konferenci, seminárú apod. pro členy BCPP

d) poŕadáni odbornych śkoleni pro pracovniky členû BCPP

e) zajištováni zahraničnich stáźi pro pracovniky clenû BCPP

f) pripravy softwarovych programú

\section{III.}

1. Spolupráce ve výse uvedenych oblastech bude konkretizována do podoby rámcových ročnich smluv uzaviraných vżdy zpravidla do konce listopadu béźného roku na dalśi kalendár̂́ni rok.

2. Rámcové ročni smlouvy budou konkretizovány do podoby béžných autorskych a jinych smluv pripad od pripadu poale potreby, zpûsobem odpovidajicim bẻz̃né praxi.

3. Vỹsledky plněni dohody budou každoročnë vyhodnocovány, a to pr̃ed uzavǐenim rámcové ročni smlouvy na dalśi rok. 
1. Tato smlouva se uzavirá na dobu neurčitou.

2. Veškeré zmény, dodatky apod. $\mathrm{k}$ tèto smlouvé musi byt provedeny pisemnou formou na základé pŕedchozího jednání obou smluvnich stran.

3. Dlouhodobou smlouvu lze vypovèdět pouze ze závažných dủvodư, a to dohodou obou stran $\mathrm{s}$ výpovĕdni Ihủtou 6 mésicú.

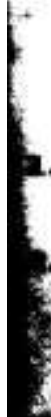

1. Tato smlouva nabývá účinnosti dnem podepsáni smlouvy zástupci smluvnich stran.

Smlouva je vyhotovena ve 2 stejnopisech.

Praze, dne

$\frac{2}{2}$

cenných p

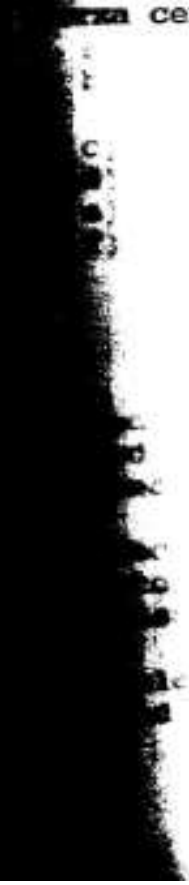

Institut pro podporu rozvoje finančniho trhu 
Pozvánka na přednáškový kurs „Finanční opce” (4.-5. 3. 1994.) Kap. 8.

\author{
$+i$ \\ 1954 INSTTTUT PRO PODPORU \\ ROZVOJE PINANČNÍHO TRHU \\ 11000 Praha 1, Skolská 16
TEL/FAX : (422) 263088
}

Văženỵ pane,

V souvislosti s usnesenim Burzovni komory BCPP zahajit na burze opéni obchody, usporadá Institut pro podporu rozvoje finanćniho trhu ve dnech 4. a 5. brezna 1994 dvoudenni speciálni kurz "Finanéni opce", na kterém budou prènảšet predni odbornici kapitálového trhu (mj. Doc.Pavlát, Dr.Budinsky a dalši).

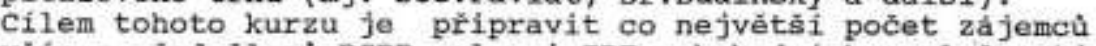
pr̂edevśim $\mathrm{z}$ r̉ad členú BCPP, ale i IPF, obchodnich spolećnosti atd., na opčni obchody tak, aby byli schopni s opcemi obchodovat se znalosti, jak vyuźit existujicich ziskovỵch príležitosti a zároveň také, jak čelit existujicim rizikùm.

Na tento kurz naváze v dubnu 1994 speciálni seminár s učasti zahraničnich odbornikú.

Misto konáni kurzu : RAPID, Praha 1, 28, rijna 13.

Cena kurzu : $2.000,-$ KC za osobu. V pŕipadé, že vysilajici organizace vyšle alespon 2 úcastniky, poskytujeme slevu $25 \%$ tj. $500,-$ Ké na osobu.

INFORMACE : IPRFT Praha 1, Školská 16, TEL. 24215010

FAX 263088, 24213001

Ing. oldríich zika

ved. divize vzdéláváni

\title{
PROGRAM :
}

1. den : $(9.00-17.00)$

1. Uvod: Zakladni pojmy

2. Základni općni strategie

3. Cvićeni $k$ tématu 2 .

4. Kombinované opčni strategie

5. Cvičeni $\mathrm{k}$ tématu 4 .
2. den : $(9.00-17.00)$

6. Oceñování opcí

7. Opce na indexy

8. Opēni trhy a opčni burzy $\mathrm{v}$ Evropé

9. Právni aspekty opčních obchodû

10. Závér semináre 
Program semináře IPRFT, Asociace a Institutu bankovního vzdělávání. (15. 2. 1995.) Kap. 8.

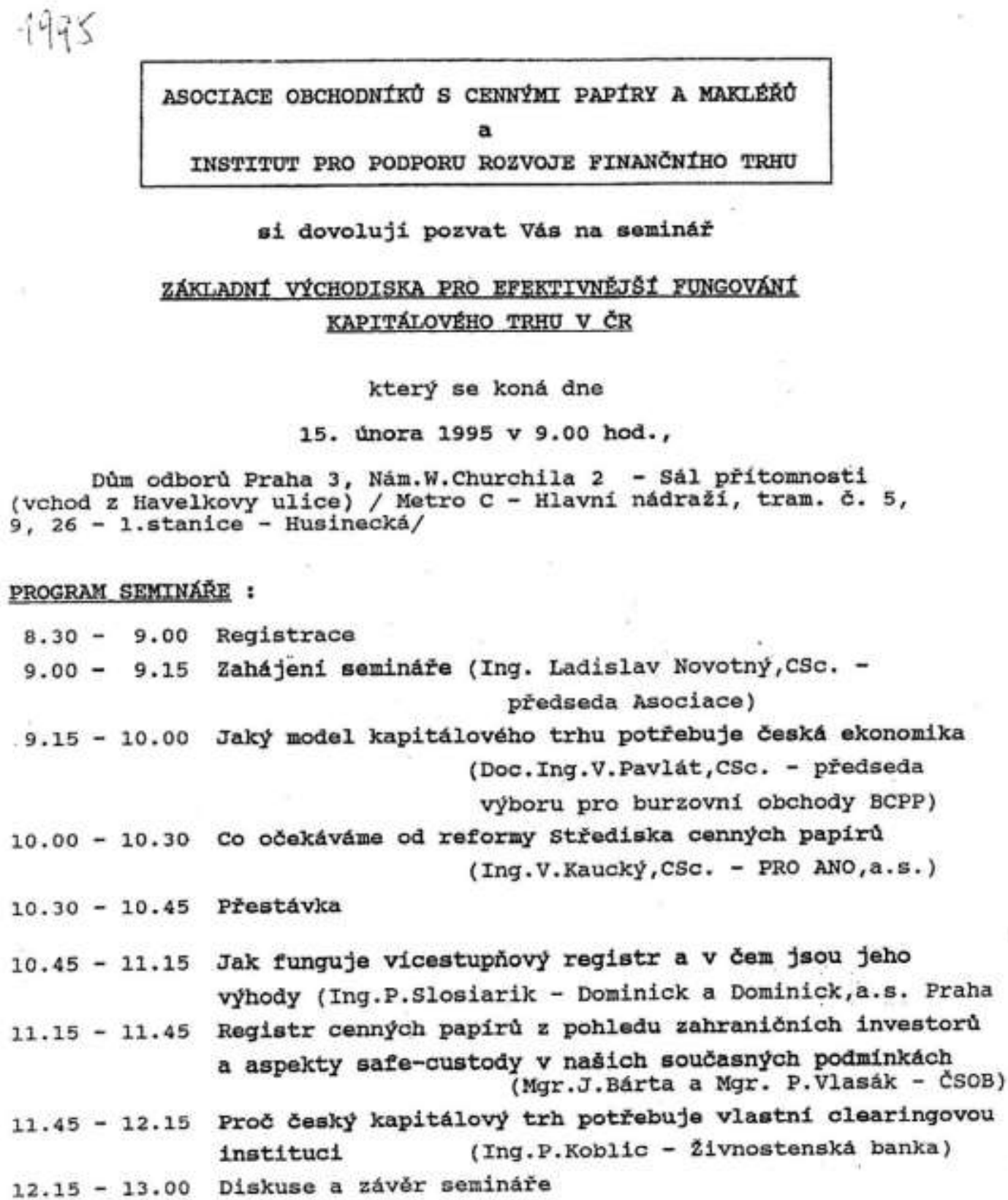


Seznam účastníků Securities Development Workshop. (23.-24. 5. 1996.) Kap. 8.

SEZNAM UČASTNIKƠ

SECURITIBS MARKET DEVRLOPMENT WORKSHOP

Praha, 23. - 24, května 1996

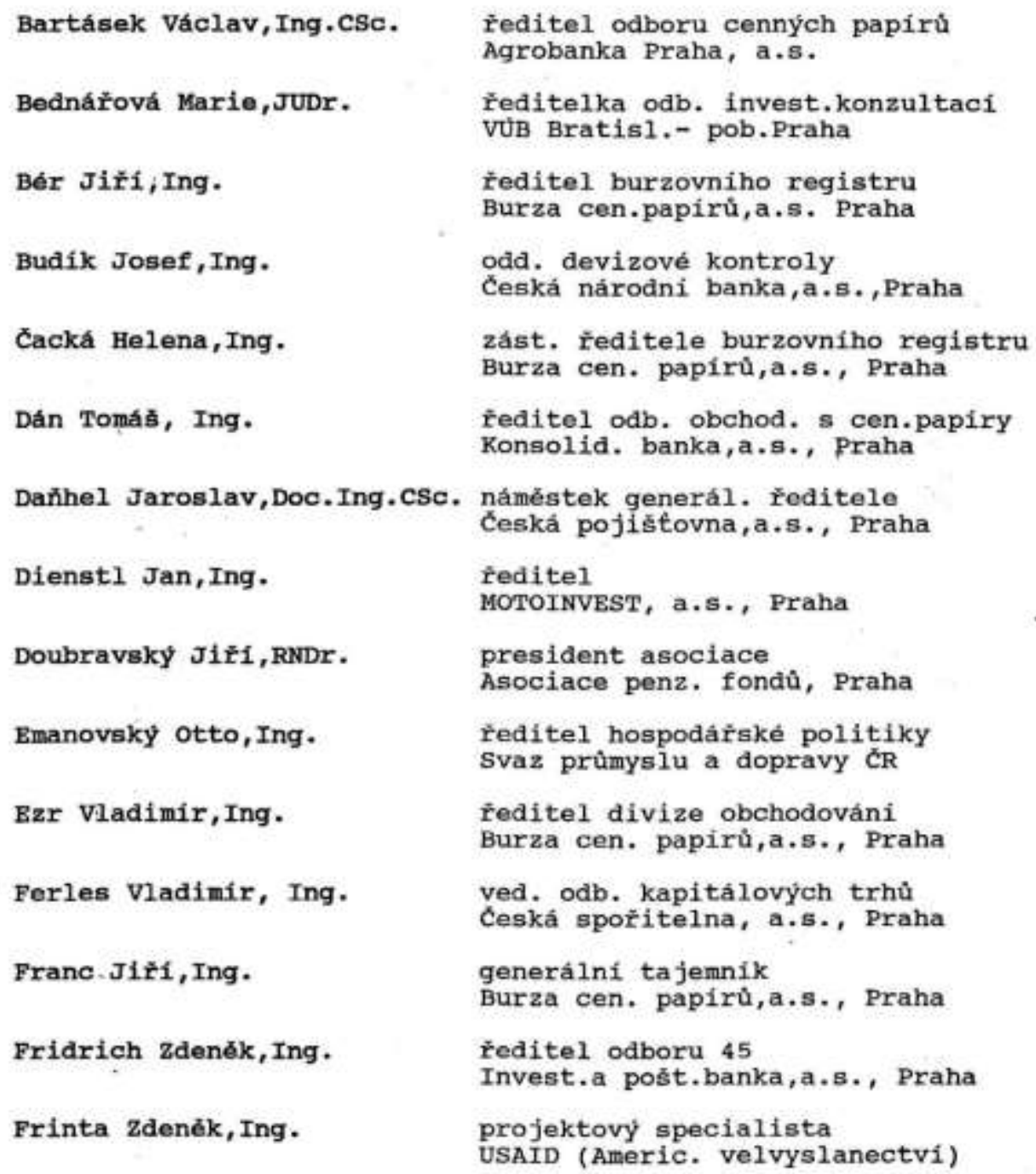


Hála Petr,JUDr.

Hollmann Pavel, Ing.

Horvath Michal, Ing.csc.

Hurajova Maria,Ing.

Chrást Lubor, Ing.

Ječny Radek

Juhász Dionỹz, Ing.

Krabec Jaroslav,RNDr., CSc.

Lazarová Barbora, Ing .

Novakk zdenék, Ing.

Nováková Marcela, Ing .

Novotný Ladislav, Ing .

Pavelka zdeněk, Ing.

Pavlát vlad.,Doc.Ing.csc.

Pavlátová J., Doc.JUDr.CSc.

Prokeš Miroslav, Ing.cSc.

Pužej Lubomir, Ing.

keznicè zdeněk, Ing . 1.námẻstek general. ředitele CORPIN, a.s.

zastupce gener. tajemnika

Burza cen. papirủ,a.s., Praha

vyzkumny reditel

Asociace obch. S CP, Bratislava

redit. divize zućtováni a vyporádáni Burza cen. papirú,a.s., Bratislava

člen vykonného vyboru

Asociace obch. S CP Bratislava

vedouci maklérského oddělení MOTOINVEST, a.s., Praha

reditel

Středoevrop.makl . dûm, Bratislav

ved. odd. analýza cen.papirú a trhu Komerčni banka,a.s., Praha

ředitelka divize kotováni

Burza cen. papirú,a.s., Bratislava

ved. odd. financi a ekonomiky

stř́edočes. plynárenská,a.s., Praha

ředitelka odboru výkonu vlast.práv Ministerstvo prûn. a obchodu CR

pŕedseda

Asociace obch.s cen.pap.Praha

ved. divize makléřských zkous̉ek CMI-Institut kap.trhu Praha

jednatel

CMI-Institut kap.trhu Praha

reditelka

CMI-Institut kap.trhu Praha

reditel divize informatiky

Burza cen. papirủ,a.s., Praha

výkonný reditel

Harvardská Burzovni společnost, Praha

ved. odd. İfzeni rizik

Ćeská národni banka,a.s., Prah 
scott Carr

strnad Tomás , Ing.

Sirek Jaroslav, Ing.

Škoda Josef, JUDr.

Školout Václav, JUDr.

Šticha Lubomir, Ing.

Tykač Pavel, Ing.

Vacek Pavel, RNDr.

Winkelhöffer Petr, Ing.

zika oldřich, Ing.
Capital Markets/International Invest. MOTOINVEST, a.s., Praha

reditel skup. řizeni portfolii

Asociace fondú, Praha

provozni náméstek

RM - System,a.s., Praha

místopr̃edseda pr̃edstavenstva

ICEBERG, a.s., Praha

1.zâstupce generál. tajemnika

Burza cen. papirú,a.s., Praha

ředitel

RM-System,a.s., Praha

generálni reditel

MOTOINVEST, a.s. Praha

ved. metod.odd. odb. polit.bankov.dohled Česká národni banka,a,s., Praha

ředitel odb. obchodováni s cen.papiry Československá obchođni banka,a.s.

ved. divize vzaẻláváni

CMI-Institut kap.trhu Praha 
Seznam účastníků konference konané 28. 11. 1996 v hotelu „President”.

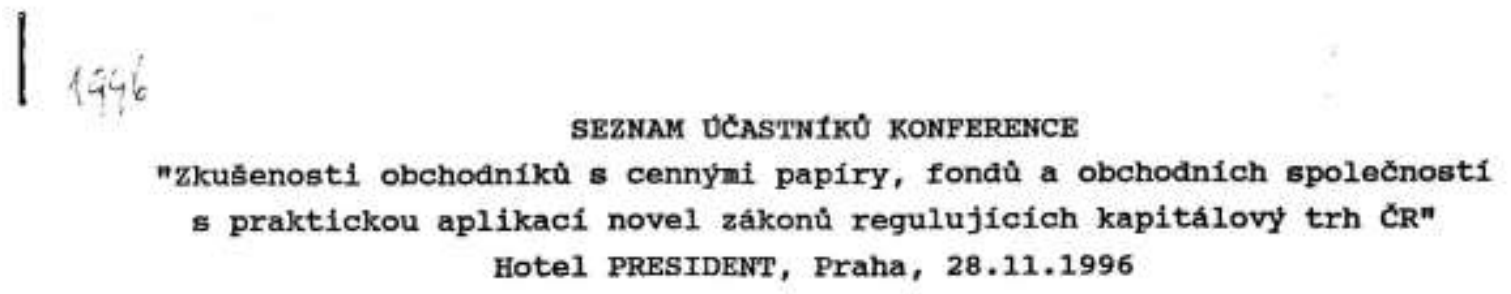

Achremenko Michal, Ing.

Balouś Milan, Ing.

Bartásek václav, Ing., cSc.

Bednáŕová Marie,Judr.

Belda Jan, Dr. ,Ing.

Bèr Jiři, Ing.

Böhm Jiři, Ing.

Ćacká Helena, Ing.

Dán Tomás, Ing.

DienstI Jan, Ing.

Dostál Jan, Ing.

Dušek Alois, Ing.

Durina Martin, Ing.

Elisák Jaroslav, JUDr.

Ezr vladimir, Ing.

Fait Igor, Ing.

Ferles Vladimir

Frinta zdenék, Ing .

Hloužek Vlastimil, Ing.

Hollman Pavel, Ing.

Horák Josef, Ing.

Horváth Michal, Ing., CSc.

Jakub František, Ing.
Lidové noviny

redaktor

AGROBANKA Praha, a.s.

reditel odboru cených papirú

GoLDIES, a.s. , Praha

reditel spolećnosti

Všeobecná úvĕrová banka,a.s. Praha

reditelka odb. investičnich konzultaci

Burzovni společnost pro kapitálový trh,a.s

vedouci odboru burzovnich obchodú

Burza cenných papirú Praha,a.s.

generalni reditel burzovniho registru

c.s.Brokers, a.s. Praha

reditel společnosti

Burza cennych papirú Praha,a.s.

reditelka divize rozvoje

Konsolid.banka,a.s., Praha

r̃editel odboru investičniho bankovnictvi

MOTOINVEST, a,s, Praha

reditel společnosti

imAGE1, a.s. Praha

generálni ŕeditel

Body Internat.Brokers, Praha

vỷkonný ŕeditel.

LIFOX,a.s., Praha

generálni reditel

Konsolidačni banka, a.s.

reditel právniho odboru

Burza cenných papirú Praha,a.s.

reditel divize obchodováni

Brno Broker Group, a.s.

reditel společnosti

Česká spoŕitelna,a.s., Praha

vedouci odboru obchodováni s cen. papiry

USAID, Praha

project specialist

MERX, a.s. Praha

roditel společnosti

Burza cenných papirú,a.s. Praha

zástupce generálního tajemnika

Unie investič. spolećnosti a fondú

predseda predstavenstva

Asociace obch. s cen. papiry, Bratislava

výkonny reditel

Ministerstvo financi $\mathrm{CR}$

vedouci odd. organizace trhu 
Janeček Václav, Ing.

Jašminsky Martin

Juchelka Jan, Ing.

Karásek Jaroslav, Ing .

Kášterskỵ Lukáš, Ing .

Kmochová Eva, Ing, csc.

Knappek Libor, Ing.

xohút Jozef, Ing.

Koltok Petr, Ing. . Kubiček Antonin,Doc.Ing., cSc.Ministerstvo financi čR

Kudliková Miroslava, Ing.

Ialinsky vladimir, Ing,

Waśek Františk

wikuleckŷ Břetislav, Ing.

mûller Śtěpán, Doc.Ing.,csc.

Mâpravnik Ivan, Ing.

Nováková Marcela, Ing.

Wovotný Ladislav, Ing., cSc.

Pavelka zdeněk, Ing .

Pavlát Vladisl.,Doc.Ing.cSc.

Petrán Rostislav, Ing.

Pospiśil Roman, Ing.

Prokes̉ Miroslav, Ing.

Prokš Jaromír, Ing .

Puz̃ej Lubomir, Ing.

Růžička Karel, Ing .

Smieško Matěj,Ing.

Srba Václav, Ing.

svoboda pavel, Ing.
Stella Group, Praha

manažer

Hospodár̆ské noviny

redaktor

Fond narodniho majetku ĆR

vedouci odd. obchod. s cennými papiry

RTP,a.s., Praha

vedouci klientského oddẻleni

LIFOX,a.s. Praha

obchodni r̂editel

Investični a poštovni banka,a.s. Praha vrchni ředitel úseku kapitál. obchodủ

Brno Broker Group,a.s.

vedoucí analytického oddélení

Ministerstvo financi SR

Moravskočeská burz. společnost, Ostrava

vedouci odd.dozoru nad kapital. trhem

Ministerstvo financí čr

vedouci oddéleni

Capital Partners,a.s.,Praha

poradce generál. reditele

Burza cenných papirú Praha,a.s.

publicisticky odbor

Squire Sanders and Dempsey

marketing manager

IB Austria Securities, ,a.s. Praha

předseda pŕedstavenstva

RM-System,a.s., Praha

analytik

Ministerstvo prủmyslu ĆR

ředitelka odboru

Asociace obchodnikú a makléřủ

predseda asociace

IPRFT, Praha

ved.divize maklér̆ských zkoušek

IPRPT, Praha

jednatel

IC Banka,a.s., Praha

výkonný ŕeditel

Komerêni banka,a.s.,Praha

nám. reditele odboru

Burza cenných papirú Praha,a.s.

reditel divize informatiky

KIS Ceské pojiśtovny, Praha

generálni reditel

Harvard.burz.spol., Praha

výkonnŷ̀ ŕeditel

ING Baring Capital Markets, Praha

vedouci prodeje

Asociace invest.spol.a fondũ Bratislava

člen prèedstavenstva

Spor̆itelni investični spol.,a.s.Praha

náměstek gener. ředit.

SATI, s.r.o., Praha 
Svobodová Lenka, Ing.

Sedý Petr,Mgr.

sirek Jaroslav, Ing .

Skolout Václav,JUDr., Ing .

Skvrnová, JUDr.

Sneberg Rudolf, Bc.

Sticha Lubomir, Ing.

Tomšejej Tomás

Troniček Jan, Ing.

Vacek Pavel,RNDr., CSC., MBA

Vašek Jiši,Dr., Ing.

Vávra Jıři, Mgr.

Vetešniková Irena, Ing.

Veverka Jan, Ing., csc.

viertl Pavel, Ing., csc.

Vlachý Jan

Wagner Michal

Winkelhöfer Petr, Ing.

Winkler Libor, Ing.

zátorskŷ Danes̉

zika oldřich, Ing

Zák Jaroslav, Ing.

Žamberskŷ Pavel, BC.
o.B.INVEST, s.r.o., Praha reditelka odb. marketingu IKS Komerčni banka,a.s., Praha náméstek reditele

RM-Systém,a.s., Praha

provozní náméstek

Burza cenných papirù Praha,a.s.

I.zást. gener, tajemnika

Asociace penzijnich fondù

vicepresidentka

CIMEX Trading,a.s.

reditel společnosti

RM-Systém,a.s., Praha

ředitel

MOTOINVEST,a.s., Praha

maklér

Ballmaier + Schultz, Praha

jeanatel

Ceská národni banka,a.s., Praha vedouci odd.bankovniho dohledu EURO ASSET Management, Praha reditel

Asociace obchodnikú a maklérù

člen výboru

Raiffeisen Capital,a.s.,Praha

prokurista

Ministerstvo financi éR

reditel odb. dozoru kapital. trhu

PROCAP SECURITIES, Praha

výkonný ŕeditel

PATRIA FINANCE, a.s., Praha

mistopredseda predstavenstva

Realia Broker,s.r.o., Moravská Ostrava

čsoB,a.s. Praha

reditel odb. obchod. s cennymi papiry

KATNEK Securities,a.s., Praha

správce portfolia

BROKER \& PARTNER,a.s., Ostrava

obchodni reditel

IPRFT, Praha

vedouci divize vzdèláváni

Pruni městská banka,a.s., Praha

reditel odboru

zvěrína a Bélohlávek,Praha

manažer projektu Is 
Předávací protokol pro Komisi pro cenné papíry. (20. 4. 1999.) Kap. 8.

\title{
Předávací protokol
}

\author{
$\begin{aligned} \text { Predávajici }= & \text { Institut pro podporu rozvoje finanéniho trhu, } \\ & \text { spol. s r.o.. }\end{aligned}$ \\ 110 Praha 1. Skolská 16 \\ Prejímaci $=$ Komise pro cenné papiry.
} 11000 Praha 1. Washingtonova 7

Na základé dopisu Koniso pro cenne papiry ze dne 30.11.1998 r.o. podává tuto závểečnoudporu rozvoje finaníniho trhu. spol. s týkajici se đinnost. zéchou a předává KCP pr̂́si. materiály naklêrskych zkouß̌ek" uzav̌̉ené na základê "Snlouvy o zajištếní republiky a Institutem mezi Ministerstuen financi ceské r.o. dne 17. února 1993 .

rámei uypou

trhu, spol. S r.o. provedl rozpracovaných aqend. provedl závěrečné práce spojene s uzavíením nedostavili ke zkoửkám. S evidencí pr̆ihlášek uchazečn, kteří se pro které Konise pro cennés. uchazečn pr̆ihlás̆ených na zkoušky. pr̆ipravou archivace materiâlo papiry zrušlla zkouškoué terminy s pripravou archivace materiála o nakleŕských zkouškách.

I.

v červenci 1998 byly Komisi pro cenné papíry předány každoroční úda je a statistiky za rok 1997 a za zkousky vykonané v $x .1998$.

Tyto údaje byly zpracovány tak jako každy rok podle pokyna $\checkmark$ inisterstua financí České republiky. resp. Úradu pro cenné papiry

Ú minulých letech byly vždy po sestavení rō̌ni úcetñ závĕrky po úhradĕ nákladô - na úcet Ministerstua financi České republiky Institut pro podporu rozpoètu zbylé finanční prostredky, tj. funqoval jako nezisková orqanizace.

Finančn prostředky zbylé za rok 1997 resp. 1998 byly poukázány na úcet Komise pra cenne papiry dne 10. února 1999.

II.

V roce 1998 bylo podáno pomĕrné nálo pr̆ihlášek ke zkouškám. pokynů KCP pokynô KCP vrácena úhrada $v$. plné vá̉ı bez odpočtu náklado̊. 
III.

Př1 př́ipravě předávacího protakolu Institut pro podporu rozvoje finančniho trhu. spol. s r.o. vycházel z podninek pro uzavrení agendy dosud pr̂̉ihlášených uchazečũ. které stanovila Konise pro cenné papiry.

Institut pro podporu rozvoje finančniho trhu, spol, s r.o. tiato předáuá Konisi pro cenné papiry a na základé tohoto pr̃edávacíno protokolu Konise pro cenné papiry pr̈ejíná dále uvedené nateriály:

(1) Archivovane doklady:

1. pr̂̉ihlášky úspẻ̉ných uchazeč̃

2. př̃ihlášky neúspěšných uchazeč̃ô (neukončené zkoušky)

3. zrušené přihlášky

4. prezenční 11stiny, pozvánky, doklady uchazę̌́

Tyto doklady jsou uloženy v 9 archivařnich krabicfch označených pismeny.

V každé krabici je uveden seznam listin, které jsou v ní uloženy.

Seznam archivovaných dokladô je uveden $v$ pŕfloze $\check{c} .1 \mathrm{k}$ tonuto protokolu.

(2) Diskety $v$ počtu 5 kusũ, obsahujíc soubory dat zahycující přihlášky ke zkouškán a údaje o zkouškách.

Popis obsahu jednotlivy̆ch souboro je uveden v pr̆rloze č.2 k tonuto protokolu.

(3) Seznan uchazečã o naklér̆skou zkouక̌ku, kterým byly podle dispozic Konise pro cenné papiry vráceny jejich priłhlásky. Tento seznam je uveden $v$ př́l loze $\overparen{c} .3 \mathrm{k}$ tonuto protokolu.

Výše uvedené nateriály za Institut pro

podporu rozvoje finančniho trhu. spol. s r.o.

prodal :

$$
\text { hy } 7 \text { is } x \text { ? }
$$

Výse uvedené materiály z pověrení Konise pro cenné papixy převzal:

v Praze ane $20.4,1999 \ldots \ldots$. 
Zápis o převzetí dokladů o makléřských zkouškách IPRFT Komisí pro cenné papíry k archivaci. (20. 4. 1999.) Kap. 8.

\section{Zápis}

Dne 20.4.1999, 9.00 -9.15 hod prevzali. v sidle Institutu pro podporu rozvoje finančního trhu spoi. s r.o.(Institut). zanèstnanci Konise pro cenné papíry (KCP) Jiři Bëhounek, otto Burę̆ a Jan Nevrzal následujíci:

(1) Archivovane doklady:

1. přihlásky úspĕs̆ných uchazeča

2. přihlášky neúspěs̆ných uchazeča

3. zrušené přihlałky

4. prezenénf litiny. pozuánky, doklady uchazečo

Tyto doklady jsou uloženy v 9 archivačnich krabicích označeny̧ch písmeny.

V každé krabıci je uveden seznam listin. které jsou v ní uloženy.

(2) Diskety $v$ počtu 5 kusô. obsahujfci soubory dat zachycující přihlášky ke zkouškán a údaje o zkouškách.

(3) Seznam uchazeča o maklérskou zkoušku, kterýn byly podle dispozic Kợise pro cenné papíry vráceny jejich přihláśky.

of iciální př̀edávací protokol o předání a pr̃evzetí výše uvedených doklado, disket. a seznana bude podepsán za KCP દ̌lenem prezidia KCP. panem Ing. Františken Jakuben, a za Institut panen doc. V. Pavláten do 10 dnâ po sepsání tohoto zápisu.

V Praze dne 20. dubna 1999
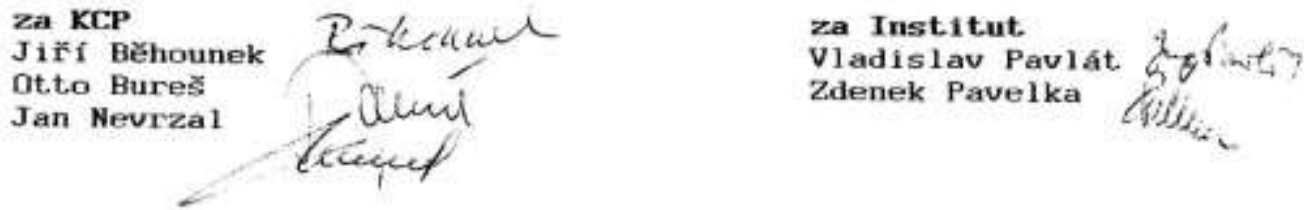